Helle Bjerg, Claudia Lenz, Erik Thorstensen (eds.)

Historicizing the Uses of the Past 
| | | | Time | Meaning | Culture

The series is edited by Egon Flaig, Daniel Fulda, Petra Gehring, Friedrich Jaeger, Jörn Rüsen and Jürgen Straub. 
Helle Bjerg, Claudia Lenz, Erik Thorstensen (eds.)

\section{Historicizing the Uses of the Past}

Scandinavian Perspectives on History Culture,

Historical Consciousness and Didactics of History Related to World War II

[transcript] | | | | | Time | Meaning | Culture 
This publication has been produced with support from The Center for Studies of Holocaust and Religious Minorities and NordForsk.

III

An electronic version of this book is freely available, thanks to the support of libraries working with Knowledge Unlatched. KU is a collaborative initiative designed to make high quality books Open Access for the public good. The Open Access ISBN for this book is 978-3-8394-1325-8. More information about the initiative and links to the Open Access version can be found at www. knowledgeunlatched.org.

\section{(c) $(1)(\Theta)$}

This work is licensed under the Creative Commons Attribution-NonCommercial-NoDerivatives 4.0 (BY-NC-ND) which means that the text may be used for non-commercial purposes, provided credit is given to the author. For details go to

http://creativecommons.org/licenses/by-nc-nd/4.0/

To create an adaptation, translation, or derivative of the original work and for commercial use, further permission is required and can be obtained by contacting rights@transcript-verlag.de

Creative Commons license terms for re-use do not apply to any content (such as graphs, figures, photos, excerpts, etc.) not original to the Open Access publication and further permission may be required from the rights holder. The obligation to research and clear permission lies solely with the party re-using the material.

\section{(c) 2011 transcript Verlag, Bielefeld}

\section{Bibliographic information published by the Deutsche Nationalbibliothek}

The Deutsche Nationalbibliothek lists this publication in the Deutsche Nationalbibliografie; detailed bibliographic data are available in the Internet at http://dnb.d-nb.de

Cover layout: Kordula Röckenhaus, Bielefeld

Proofread by: Müller Translations

Typeset by: Erik Thorstensen

Printed by Majuskel Medienproduktion $\mathrm{GmbH}$, Wetzlar

Print-ISBN 978-3-8376-1325-4

PDF-ISBN 978-3-8394-1325-8 


\section{Contents}

$\begin{array}{ll}\text { Introduction } & 7\end{array}$

\section{Cases of National History Cultures}

Representations of Victims and Guilty in Public History. The Case of the Finnish Civil War in 1918

SIRKKA AHONEN

The Holocaust as History Culture in Finland

TOM GULLBERG

The Nazi Camps in the Norwegian Historical Culture

JON REITAN

The Norwegian Fascist Monument at Stiklestad 1944-45

TOR EINAR FAGERLAND AND TROND RISTO NILSSEN

The Holocaust and Memory Culture: the Case of Sweden

KRISTIAN GERNER

Small and Moral Nations.

Europe and the Emerging Politics of Memory

CeCILIE Felicia StoKholm BANKE

\section{Historical Consciousness in History Didactics}

Processing Time - On the Manifestations and Activations of Historical Consciousness

KLAS-GÖRAN KARLSSON 
German History Didactics: From Historical

Consciousness to Historical Competencies - and Beyond?

ANDREAS KÖRBER

Coping with Burdening History

BODO VON BORRIES

III The Mediation of History in Practice

Exhibiting the War. Approaches to World War II

in Museums and Exhibitions

OLA SVEIN STUGU

World War II at 24 Frames a Second -

Scandinavian Examples

207

ULF ZANDER

Historical Propaganda and

New Popular Cultural Medial Expressions

227

ERIK THORSTENSEN

The Culture of Memory in the

"Grandchildren Generation" in Denmark

241

HELLE BJERG

Strengthening Narrative Competence by

Diversification of (Hi)stories

Claudia LENZ

How to Examine the (Self-)Reflective Effects

of History Teaching

BODO VON BORRIES

Contributors 


\section{Introduction}

HELlE BJERG, ClAUdiA LENZ, AND ERIK THORSTENSEN

In 2010, the German invasion starting five years of occupation in Denmark and Norway is being commemorated in a special way. 70 years after the events, only a few of the eye witnesses are still alive and the traumatic past is about to be transformed from "communicative" to "cultural" memory (Assmann 2004). 65 years after the end of World War II, a fourth generation is learning about the events in school, through media and, less and less, through the stories told in families. The different generations communicating about the war have experienced different ways of telling - or silencing - stories about the war, as they have witnessed different commemorative cultures and political uses of this past. But even 65 years after the breakdown of German National Socialism and the liberation of the former occupied countries, this war is by no means fading away from public debate and media. "The war" is still capable of engaging people and mobilizing strong feelings.

The ambition of this volume is to diagnose and position the history and commemoration cultures of the Scandinavian countries within broader tendencies and recent developments of the history culture of WWII in an international perspective. In order to do so, it is necessary to devote particular attention to the Holocaust-related commemoration and history culture. The articles in this volume dealing with the different national cases will show that the most significant changes in the national representations and interpretations of WWII during the last decades are in one way or another linked to the integration of the Holocaust into new national narratives and to new patterns of interpretation.

In this field, a confusing variety of concepts has emerged, which partly seem to have synonymous, partly overlapping meanings, and 
which are not always used in coherent ways. Therefore, we would first of all like to clarify our use of some core concepts in this introduction which does not, however, in every instance necessarily correspond with the ones chosen by the authors in this volume. The variety in uses of concepts mirrors, in effect, different backgrounds with regard to academic disciplines and "schools".

To start with, the perhaps most confusing distinction in the field is the one between "collective memory", "memory culture" and "history culture". Some scholars doubt that such a thing as collective memory exists, arguing that memory is a phenomenon linked to the individual ways of turning experiences into mental and emotional representations. Others interpret memory as a social and communicative process of attaching meaning to the past, mediated by cultural activities. Here the terms social memory and cultural memory indicate the activity of creating or constructing memories, whereas the term collective memory points to the fact that memories serve to construct group identities and cultural traditions (see Erll/Nünning 2008).

Memory culture is often used to describe the complete field of cultural representations and practices dealing with a specific past. Still, it seems more appropriate to reserve this term to all phenomena which are related to commemoration and coming to terms with the past, whereas history culture signifies the whole spectrum of ways the past is addressed and used in a society.

In this volume, the diagnosis of history culture is addressed within the perspective of history didactics. This means inquiring how these developments with regard to the interpretations and uses of the history of WWII and the Holocaust raise new challenges and possibilities for history teaching. The main focus here lies on the question whether the opening up of monolithic national master narratives to incorporate grey zones, ambivalences and a more reflective attitude corresponds to new approaches to historical learning and teaching. These might include replacing authoritative fact canons with the reflection about the ways the past has been interpreted and used at different times and in different contexts, including one's own contemporary situation. This perspective of history didactics, understood as a meta-perspective on learning and teaching history, is addressed throughout this volume, but especially in the second and third chapter.

In order to specify the kind of questions to be raised and discussed within a mainly Scandinavian comparative framework throughout this volume, we shall start this introduction by providing a small glimpse of the history culture in Denmark and Norway respectively, represented by two recent films. We will then go on to summarize the primary ques- 
tions of the volume and outline some of the general tendencies within the history culture of WWII and the Holocaust reflected within individual contributions. Finally, we will give a brief presentation linking each contribution to the shared perspectives.

In 2008 and 2009, it seemed that the Scandinavian resistance hero had made his comeback. Two films, a Danish and a Norwegian production, were released, both of them dealing with the resistance against the German occupation of the respective country. But, even if both films played on well-known topics from national history cultures, they dealt with them in quite different ways and, consequently, provoked very different reactions in the Danish and Norwegian public. One could say that each film represents an antipodal landmark in the memory landscapes that have emerged during the more than six decades since the end of WWII.

On the one hand, there is the Danish film Flammen og Citronen (Flame \& Citron), released in 2008 and featuring two members of the Danish resistance movement who are shown as being responsible for the "liquidation" of people considered to be collaborators and to represent a danger for the activities of the resistance movement. Still, the narrative of the movie is not as clear-cut as the last sentence might indicate. The two heroes are portrayed as being under heavy nervous and physical strain, not only due to their brutal task, but also because they are drawn into intrigues within the resistance movement. They even suspect that they are being manipulated into killing innocents, thereby entering the grey area of virtually committing murder. The film leaves the question open whether personal animosities and power struggles within the resistance movement might have been the motives behind some of these "liquidations". The heroes have turned into anti-heroes; their depressed and at times desperate state of mind undermines the narrative of a resistance movement fighting a just war against a foreign occupier - in the name of the people.

On the other hand, the Norwegian film Max Manus, released in 2009 , carries the name and tells the story of a resistance hero - even one of the best known, belonging to a legendary group: the "Oslo gang". While Flame \& Citron undermines patterns of black and white, confronting the narratives of heroes and villains with shades of grey (at times very dark grey ...), the actions and motives of the heroes of Max Manus are still beyond any doubt and suspicion. The members of the "Oslo gang" are depicted as those who take action in a situation when being occupied by an overwhelming military power caused lethargy among most Norwegians. In addition, the heroes of Max Manus gain their legitimacy through the exiled leaders of the country. In one scene, 
Max Manus meets the Norwegian king Haakon VII (being himself a mythical figure representing "the-nation-in-resistance") in his British exile. When the king encourages him, Max Manus and his actions are symbolically ennobled. When Max Manus is worn out and depressed at the end of the film, it is not because he has lost faith or because he is confronted with moral doubts. Max Manus' depression is easily explained because he is the only survivor of the Oslo gang - it is the price he paid for his heroic fight. It is his personal sacrifice. This makes him, of course, even more a hero.

The success of both films and the reactions they provoked leave no doubt as to which of the two narratives is the more appealing. Flame and Citron won much critical acclaim as a nuanced representation of war history and drew a large audience in Denmark (about 700 000) as well as abroad. But it came nowhere close to the success of Max Manus first of all in Norway. More than a million Norwegians saw the film in the cinemas and it was proclaimed the most successful Norwegian film of all times (taking over from Nine lives, a resistance drama from 1957).

Moreover, both films caused quite different reactions among critics and historians. Flame \& Citron provoked a dispute among historians over alleged lapses in the presentation of historical facts and, accordingly, the degree of fictionalization. No debate of this kind arose after the release of Max Manus. It was praised for its "realism" and "authenticity". The voices of critics accusing the film to present an outdated blackand-white image of war and resistance drowned in the choir of euphoria, including resistance veterans, politicians and even the present Norwegian king Harald VII.

In Norwegian cinemas, one could observe how the film became a matrix for intergenerational transmission of historical knowledge and memories, when grandparents took their grandchildren to a film that supposedly showed the "real past" and linked to their own war experiences. Appealing to the younger generation's sense for dynamic and action and at the same time authorizing grandparents as contemporary witnesses, the film obviously succeeded in building bridges between generations. Still, it did not include recent developments in Norwegian history culture, namely the inclusion of grey zones and less flattering topics than that of a purely heroic resistance. In other words, the movie Max Manus could be regarded as being anachronistic both in relation to contemporary history culture (since it omits several of the perspectives that have been publicly debated in the last years), and when it comes to the "state of the art" of historical research, which also embraces a broader spectrum of perspectives than displayed in the movie. How, then, can the major success of such a representation of the war be explained? Within 
the broader picture of history culture, Max Manus seems to represent a kind of permission to stick to the positive aspects of occupation history, those aspects easy to identify and to cope with. In stark contrast to Flame \& Citron, it doesn't challenge the notions of the right and the wrong side and the unambiguous good cause. Still, there are traces of recent developments in history culture visible in Max Manus: some years ago, it would have been impossible to see the hero in despair and depression, while his country is celebrating liberation. A diachronic comparison of different movies displaying war heroes since 1945 would yield interesting results in this respect. And here, again, the perspective of history didactics is touched upon: How can an understanding of the dynamics of the success of Max Manus contribute to an understanding of the mechanisms of individual and collective uses of the past in general?

The two films and the reactions they provoked are specifically connected to the Norwegian and Danish situation, which means to the specific war history and the commemorative and history cultures that evolved after 1945. Two other Nordic countries, Sweden and Finland, went through very different war experiences - which we will come back to later in this introduction - and both countries went through their own processes of coming to terms with this past - including commemoration, historization and other cultural forms of representing and using the past. A common topic dealt with in the contributions of this book is the difficulty of coping with problematic aspects of this past, which means: fully integrating them into the narratives and images circulating in history cultures.

Still, what applies to all national cases dealt with in this book is the double function of cultural representations of war history: the duplicity of mirroring and affecting public history cultures related to WWII. This means, in Michel Foucault's terms, that the elements of history culture are inscribed into cultural systems of meaning which regulate the possible uses of the past ("what can be said and thought" about a certain period of the past) and at the same time constitutes these systems, related to the possibility of change. In this way, the example of Flame \& Citron and Max Manus touch upon a variety of topics which this book is going to highlight:

- The transformation of experiences of WWII into commemorative practices, individual and collective memories and public history cultures.

- The role of the representations of war as a source for individual and group identities.

- The conflict over "true" and "legitimate" representations of the past. 
- The tension between national and universal narratives as well as between identity-focused and reflexive frameworks informing the representations and uses of the past.

- The "pedagogical" impacts of the normative and formative functions of all kinds of representations and uses of the past - and the challenges for didactics of history related to this.

This book represents the attempt to connect the developments on a societal and scientific level and to present them within a Scandinavian comparative framework:

- Which challenges and possibilities of the didactics of history are prompted by the changed European and Scandinavian historical culture and the changed use of history, with a view to the mediation of WWII and the Holocaust?

- How can the concept of historical consciousness be elaborated theoretically and empirically with regard to a mediation of history aiming to develop a self-consciousness of history and a use of history which supports the democratic political culture?

- How can theoretical insights about the consciousness of history, the use of history and the culture of history be transformed into concrete methods of teaching?

- How can an improvement of the level of historical reflection about WWII and the Holocaust be adequately described and evaluated?

The intention of this book is to combine scholarly work and empirical examples in the fields of historical consciousness, history culture and didactics in order to show in which ways they inform and inspire each other. The concept of historical consciousness represents the theoretical linkage between the studies of history cultures and didactics of history. Since history teaching in the Scandinavian countries is focused on the strengthening of critical thinking and the consolidation of democratic values, the concept of historical consciousness has traditionally occupied a strong position. Still, there has been little reflection on the consequences of the changing history culture with regard to the history of WWII for learning and teaching history. This anthology is a contribution to a debate about how the insights into the narrative formation of historical consciousness and the uses of the past which have materialized in the study of history cultures, can be integrated into didactics of history and thereby become sources of (self-)reflective historical learning processes. Much of the work done at memorial sites and in other institutionalized spaces of historical learning in the Scandinavian countries can be regarded as "good practice", enhancing competences in historical thinking 
and in participating in the negotiations of the past in society. Thus, the aim of the anthology is to facilitate an interdisciplinary dialogue between different fields of research, to integrate a Scandinavian perspective into ongoing European debates, and finally to bridge the gap between scientific debates and teaching practices in the field of history cultures with reference to WWII and the Holocaust.

History culture is conceptualized as a field of cultural practices which serve individuals and social groups/communities to make sense of the past, and which has a crucial function for the establishment and regulation of a social order (including power relations). Due to these features, history culture can serve as a brilliant starting point for historical thinking and for didactics of history. Thus, in this volume a variety of examples of "history culture in action" from different national contexts in Scandinavia are presented, and confronted with the "meta-discourse" established by the theoretical and didactical contributions. The idea behind the choice of contents and its structure is to introduce the concept of the "reflexive turn" with regard to the history of WWII and the Holocaust. The concept of a reflexive turn points to the increasing attention on the question of how this period was remembered and turned into a "usable past" after 1945. This process is related to a tendency of demythologization, deheroization and a decreasing influence of the patriotic master narratives which formerly dominated the postwar era. Today, local, national and global narratives and interpretative patterns alike contribute to what Levy and Sznaider call the "de- and renationalization" of history cultures with regard to the Holocaust (2005). This means, that not only a "supra-national" knowledge about history, but also "supranational" patterns of interpretation have emerged. This development has the paradoxical effect of re-enforcing national historical narratives, by modernizing and adapting them to contemporary needs for identity building and the search for political legitimacy. An example of this is the tendency of nation states to confess their guilt regarding the persecution of the Jewish population during WWII. This recognition of national guilt has become a condition for political legitimacy in the context of foreign policy, as described by Cecilie Stockholm Banke in this volume. Considerable research has been done on these phenomena in many European countries, but so far a comparative perspective on the Scandinavian countries is missing. 


\section{Shifts in the history culture in Scandinavia}

In recent years a conceptual shift has occurred both in the Nordic countries and in other European countries regarding the approach to the history of WWII. This shift applies both to research, to the public culture of memory, and to the common historical consciousness about WWII. In the early postwar years, the national "master narratives" about war and occupation had an elementary meaning for material and moral reconstruction of the war-affected countries and for the establishment of a postwar political order. In the later postwar years, these master narratives have been confronted with perspectives focusing on opposing, ambivalent and painful aspects of the history of war. In Norway and Denmark, Eriksen (1995) and Bryld/Warring (1998) published critical analyses of the mythologizing tendencies in the national "consensus narratives" (Fure 1997) about collective opposition during the war. These studies prompted a new tendency towards "demythologizing" the history of war, focusing on earlier forgotten or suppressed aspects.

Ten years later it can safely be said that a paradigm shift is taking place, both within historical research as well as within public accounts and presentations of the history of WWII. As far as the reasons for a "reflexive shift" in the treatment of WWII are concerned, one has to consider not only demographic but also political factors. The war generation is no longer the generation shaping the agenda - neither economically and politically nor in the cultural and academic debate. This means that the vision of a society molded by war experience has been replaced by visions linked to postwar experiences. During the 1980s and 1990s the so-called "generation of 1968 " became an important player in cultural and political life, enabling representatives of this generation to exert a considerable influence on interpretations of history. At the same time, new "agents of political memory" came to the fore. In Norway, the society of "War children" was founded in 1985 and constitutes an example of a social group belonging to the "generation of children"; this group made its voice heard in the struggle for memory and its political consequences when its members had reached middle age.

In Sweden, the national narrative of a neutral Sweden during WWII was challenged when Boëthius (1991) subjected Sweden's relationship to Nazi Germany to critical investigation. This prompted the debate about "Jewish gold", the rejection of Jewish refugees, etc. As a result, the Council of Science granted 20 million Swedish kroner in order to conduct research on the topic "Sweden's Relations with Nazism, Nazi Germany and the Holocaust: A Research Programme" and the Forum for Living History was founded, becoming an important player within the 
formation of history culture in Sweden and abroad, as will be shown in some the contributions by Gullberg, Gerner and Banke.

As the celebration of the liberation in 1995 has shown, the "national consensus syndrome" (Grimnes 1990) was still predominant both in Denmark and Sweden at that time. And yet the historical culture of the Scandinavian countries presented in this volume underwent significant changes during the 1990 s, due to shifts within the national political culture of the postwar years as well as under the influence of an increased globalization. Globalization occurs not just on an economic, but also on a cultural level, not least due to new patterns of migration. With a view to the cultures of history and memory, this means that the focus on national unity loses some of its identifying and legitimizing significance.

One decisive factor in this new interpretation process came from outside: the realization that the persecution of the Jews and the Holocaust is a historical theme which concerns all European nations - regardless of whether they were confronted with the policy of extermination as an occupied or (apparently) neutral nation. The cases involving damages which took place during the 1990s in Switzerland, Sweden and Norway were enormously important politically, scientifically and culturally in terms of a new interpretation and a paradigm shift in the national presentation and interpretation of history. It is no exaggeration to claim that the paradigms of history writing were shaken in this period. The categories "us" (patriots) and "them" (inner or outer enemies) could no longer be sustained, or acquired a bad off-taste. Where, for example, were the Jews to be situated on this mental map: as a minority or as refugees? Also in this regard, the Finnish War history seems to be the most complex of the Nordic countries. Fighting at times together with Nazi Germany against the Soviet Union, the self image of Finland was for a long time formed by the idea of having been first and foremost a victim of WWII and of not being involved in the Holocaust. These notions have quite recently been challenged by a younger generation of historians asking questions of responsibility and guilt which have been avoided for decades. It is symptomatic for this trend that Michael Burleigh's last book on WWII is called Moral Combat, and addresses the moral choices made by key protagonists (Burleigh 2010).

In all these countries, the lasting concern with the Holocaust has also left its mark on historical research and on the culture of memory. Today it is no longer possible to present the history of the war without addressing the issue of the Holocaust. The formative aspects of history teaching are no longer related to, and solely informed by, patriotic identification with the resistance heroes, but rather linked to values more closely asso- 
ciated with global problems of today and related to the promotion of human rights, democracy, and peace.

Such a perspective can be seen as a new area of commitment in the presentation and teaching of history; the effects or interpretation of history (linked to the German concepts "Wirkungsgeschichte", "Deutungsgeschichte") are regarded as important within the formation of historical consciousness, and as such issues to be addressed within history didactics.

The different chapters of the anthology will address these new tendencies within memory and history culture and didactics of history.

\section{Cases of national history cultures}

In the first chapter, Cases of national history cultures, the contributions present actual investigations of how national cultures of memory of WWII within Scandinavia seem to move within new directions. The tendencies shown throughout the national cases seem both to be opening up to more pluralist views upon national history, and keeping a stronghold within national identity building.

This part opens with the contribution Representations of Victims and Guilty in Public History. The Case of the Finnish Civil War in 1918 by Sirkka Ahonen. Ahonen stresses how it is vital to understand WWII in the light of the Russian Revolution in 1917 and the Finnish Civil War which divided the Finnish society into Whites and Reds. This division has cast shadows into the culture of memory of Finland until today, and Ahonen uses the perspectives of victimization and guilt in a discussion of how a society can reconcile itself with different interpretations of the past.

In The Holocaust as History Culture in Finland, Tom Gullberg explores the national debates of Finnish historians concerning the history of the Finnish WWII and the Finnish Cold War. This national debate is related to a larger European discourse about the role of the Holocaust in creating a common European standard for morality and, subsumed under this, the place of Holocaust education in relation to the national history culture. Under the theme of Holocaust education the connection to the Swedish governmental institution Living History is explored, an institution also examined closely in the contributions by Gerner and Banke.

The European concentration camp system creates the setting for Jon Reitan's article The Nazi Camps in the Norwegian Historical Culture. Reitan explores a change in Norwegian memory culture where the Nazi camps have moved from the margins of the national historical culture in- 
to occupying a central position in the public consciousness. Reitan argues that this should be seen as an attempt to stabilize and systematize memories and messages from WWII. This analysis corresponds with Karlsson's exploration of different forms in which history is used. Reitan's analysis shows a dialectics between rendering the past fixed in a location with a paradigm of fascination for the concrete and the creation of strong transnational and placeless narratives and meta-narratives interpreting the Holocaust. This tendency of a "glocalization" of the Holocaust is also addressed by Banke and Bjerg in this book.

The changes in interpretations and uses of historical places in Norwegian history culture are also the theme in Tor-Einar Fagerland and Trond Risto Nilsen's chapter The Norwegian Fascist Monument at Stiklestad 1944-45. By focusing upon Stiklestad, often regarded as the founding place of Norway as a Christian nation, the authors investigate how different layers of (national) history have constructed a symbolic place that most Norwegians take pride in even today. Still, the use of Stiklestad as a rallying point for the Norwegian Nazi Party and Vidkun Quisling is a bone of contention within the contemporary uses of the site. As such, the authors suggest a redesigning of Stiklestad as a site of commemoration aimed at exposing the different archeological layers of the uses of the past connected to the site.

Kristian Gerner also analyzes contemporary debates on interpretations of the past in The Holocaust and Memory Culture: The Case of Sweden. Gerner focuses on the Swedish governmental body, "Living History", which studies and disseminates knowledge about genocides and violations of human rights. The article investigates the different receptions of the Holocaust within Sweden, connected to the position of neutrality, the position of Sweden as the savior related to the White Buses, but also recent modifications of the Swedish self-understanding in relation to new perspectives on the Swedish involvement in the Holocaust. Gerner also addresses the recent initiatives to broaden the original scope of the "Living History" from focussing on the Holocaust to studying and addressing Swedish attitudes towards other genocides or mass killings, as in Cambodia or in the Stalinist Soviet Union and how these have spurred vehement reactions and protests of the Swedish political left regarding both the validity and the possibility of comparing Nazi and Communist crimes.

In her article Small and Moral Nations. Europe and the Emerging Politics of Memory Cecilie Felicia Stokholm Banke establishes a link to the topic of universalization of the Holocaust as found in Reitan's contribution. Banke analyzes how the re-actualization of the Holocaust through the Stockholm International Forums created both national poli- 
cies and the wider field of genocide studies. As touched upon earlier in this introduction, the national narratives of WWII in the Scandinavian countries have turned towards embracing a new universal morality. Hereby a new policy regime has been framed where human rights could find their way into international politics. Banke relates these tendencies to the development of a denationalized European memory culture in which Holocaust is related to through remembrance. This establishes a break in the former national memory cultures focusing on confrontation, interpretation, and justice. Banke discusses how putting morality on the agenda of international politics may open up new possibilities for smaller states to become bigger moral players.

Looking at the different national case studies, one can easily see common traits in the dynamics of public history culture and politics of history. There seem to be similar mechanisms at work with regard to the formation and negotiations of narratives and interpretative patterns as well as with regard to the negotiations and disputes about legitimate and illegitimate uses of the past. Apparently, the need and capability to handle and cope with unflattering and burdening aspects of the past was not there before the 1980s in any of these countries, and the process of really integrating the "darker sides" of the past into national history and related self-images seems to be an ongoing one. As is the dispute about the consequences of these changing images of the past for contemporary values, political decisions and power relations. The contributions in chapter II within this volume provide theoretical frameworks for understanding these mechanisms of history culture and politics of history. The contributions in chapter III will introduce perspectives on how to teach and learn about history cultures and some theoretical arguments for the impact this kind of understanding has for active citizenship.

\section{Historical consciousness in history didactics}

The contributions within this chapter take historical consciousness as their starting point for theoretical elaborations of how to conceptualize uses of history and historical thinking. The debates raised in this chapter serve to give a theoretical framework for the study of national cultures of memory and history as presented in Chapter I as well as for the didactical reflections and concepts to be presented in Chapter III.

The first two contributions, Processing Time - On the Manifestations and Activations of Historical Consciousness by Klas-Göran Karlsson and German History Didactics: From Historical Consciousness to Historical Competencies - and Beyond? by Andreas Körber, give an 
outline of different theoretical developments building on the groundwork of the concept of historical consciousness - the focus on history culture, on one hand, and that on didactics of history, on the other. Together, both articles provide a conceptual tool kit for the description, reconstruction and analysis of the ways in which individuals and social groups make sense of the past, the ways in which the past is linked to contemporary issues and future prospects, as well as the narratives, artifacts and practices that are bearers of historical meaning.

Karlsson's contribution starts with reflections on the conditions for the past to manifest itself in the present and how this manifestation is mediated. His key argument for transcending the limits of the concept of historical consciousness is related to this topic of mediation: there is no way to understand the processes of making sense of the past and the uses of the past without looking at culture, more accurately: history culture. When it comes to the ways of using the past displayed in history culture, Karlsson differentiates between:

- The scholarly-scientific use of history

- The existential use of history

- The moral use of history

- The ideological use of history

- The politico-pedagogical use of history

In his contribution Körber argues for using the concept of historical consciousness as a pathfinder with regard to history culture and the processes of attaching meaning to the past - which presupposes that everyone has the capacity to "process time" in different ways and for differing purposes. He develops a concept of historical thinking, consisting of a number of operations, which enables an individual to perform what is described by Karlsson as "processing time". Körber draws on the development of the concept carried out within the German network FUER Geschichtsbewusstsein (Schreiber et al. 2008) and suggests a shift of focus from historical knowledge to historical competence. Using the concept of "(self-)reflective historical consciousness", Körber describes two basic narrative operations of historical thought: reconstruction of historical events and courses of action and deconstruction of existing narratives and interpretations. This new thinking has not yet been integrated into the Scandinavian debate about the didactics of history, but is reflected in some of the contributions with a didactical perspective in Chapter III.

The article by Bodo von Borries, Coping with Burdening History, takes its starting point in the question of "coping with history". He applies the assumptions developed by Körber when describing different 
forms of overcoming hate and animosities between nations produced by difficult and traumatic histories. After describing forms of collective attitudes towards a traumatic past which maintain and prolong hatred he outlines various initiatives of constructing historical narratives that aim at bridging former dividing lines.

\section{The mediation of history in practice}

This chapter moves the theoretical debates of the development of historical consciousness into analyses of empirical examples of the mediation of history within a didactical perspective. The chapter offers examples of how WWII and the Holocaust are presented within different types of media, and of how history culture is both reflected and addressed within specific cases of history education. The articles in this chapter reflect the broader changes in the history culture of WWII and the Holocaust outlined in chapter I, briefly summed up as universalization, victimization, moralization, de- and renationalization. In that sense, this chapter elaborates on how these tendencies are crystallized within very different settings. Furthermore, the different contributions are to some extent informed by the theoretical development of the concept of historical consciousness outlined in various ways in chapter II. As such, the overall theme of chapter III is the question of how to develop a (self-)reflective historical consciousness. This question is dealt with more or less explicitly in the analyses and evaluations of the various examples of mediation of history in practice.

The first contribution by Ola Svein Stugu: Exhibiting the War. Approaches to World War II in Museums and Exhibitions provides a general framework of "reading" war exhibitions with regard to national and supra-national narratives and interpretations. As such, the article presents a framework for the perception of how the tendencies in the history culture of WWII and the Holocaust present themselves within the museum exhibition as a specific form of representation, as well as in very diverse national contexts.

In World War II at 24 Frames a Second - Scandinavian Examples, Ulf Zander carries out analyses of films relating to WWII and the Holocaust in Sweden, Norway and Denmark, and his analysis shows the close linkage between media representations as moving images and history culture. The analysis focuses on the understanding of these movies within different national history cultures in Scandinavia, and shows how the movies can be seen as products and producers of history culture in the sense that they reflect the interpretations of a given period in the 
light of the time of production. In a didactical perspective the elaboration by Zander on the relation between history culture and films paves the way for the development of didactical approaches using films in contextualizing, historicizing and deconstructing war narratives.

With the article by Erik Thorstensen: Historical Propaganda and New Popular Cultural Medial Expressions we move into the framework of history teaching and historical learning within the context of a specific exhibition. The article presents and evaluates a teaching concept developed and used in relation to an exhibition on Leni Riefenstahl, presented in 2008 at the Holocaust-centre in Oslo. The teaching concept presented is developed on the basis of the concept of reflective historical consciousness, and Thorstensen points to the difficulties encountered when attempting to develop several of the historical competences introduced by Körber. Especially clear is the danger of producing moral(izing) statements lacking historization and critical judgments by only taking the past as a "stepping stone" for declamations about the present.

The article by Helle Bjerg: The Culture of Memory in the "Grandchildren Generation" in Denmark follows up on the outline of recent developments within history and memory culture in an empirical analysis of how these tendencies are reflected and developed within the historical consciousness of the "third" generation in Denmark. Furthermore, the analysis points to the didactical perspectives and challenges posed by a generation where the manifestation of the ongoing relevance of WWII and the Holocaust within the memory culture goes hand in hand with a strong tendency of de-historization and universalization threatening to empty the use of history of the complexities of a specific historical context. Here the article is in line with the contribution by Jon Reitan pointing to the impact of "globalized memory" detached from place and time and the contribution by Thorstensen pointing to a dehistoricized use of history where a universal moral message becomes the - only - content of history. This opens up a question of how to didactically confront the paradox of what might be termed as "forgetful remembering".

This question is followed up in the contribution by Claudia Lenz: Strengthening Narrative Competence by Diversification of (Hi)stories, Lenz presents a case of teaching history teachers within the context of Norway's Resistance Museum (Norges Hjemmefrontmuseum) where a specific learning tool was implemented aiming at developing narrative competence by challenging the participants to re- and de-construct historical narratives of WWII. As such, the case serves as an empirical example of how to operationalize the didactical focus on the development of (self-)reflective historical thinking as theoretically elaborated by 
Körber in this volume. Lenz links up with the various contributions within this volume (in particular with those of Reitan, Stugu and Bjerg), pointing to how different layers of history culture intermingle when historical consciousness is put to work within the task of reconstructing and deconstructing existing historical narratives. Finally the case also exemplifies how the historical learning processes are closely related to the capacity of actively participating in the ways the past is used in society, not least related to matter of "burdening history" as discussed by Borries.

Several of the articles in this chapter explicitly deal with didactical approaches and learning methods where the materializations of history culture are put into didactical practice in order to activate a full-fledged historical thinking. The idea of (self-)reflective historical thinking building on the model of a whole range of historical competences raises serious challenges in regard to the evaluation of learning processes and the assessment of individual learning progress. The final contribution by Bodo von Borries: How to Examine the (Self-)Reflective Effects of History Teaching takes up this challenge by suggesting various forms of testing which genuinely aim at grasping and diagnosing learning processes leading to (self-)reflective historical thinking. Against the backdrop of a critique of the widespread tendency of testing factual historical knowledge, Borries presents some promising examples designed to test the competence of historical method by carrying out historical reflection rather than just answering factually oriented questions.

The common aim of all contributions in this volume is to build bridges between the empirical finding that history and memory cultures related to WWII have become "reflexive" in the sense of a critical evaluation of narratives of national heroism and suffering on the one hand, and approaches in history didactics taking this reflexivity as a starting point for fostering historical competences and critical judgment, on the other. Theories of historical thinking and historical consciousness - understood as "processing time" - serve as transmitters between the case studies of national history cultures and the didactical case studies. The reflection of the processes transforming the past into history and linking it to the present and future informing the teaching approaches presented here, takes its cue from the insight that human beings' understanding and interpretation of the past are crucially important for individuals' and social groups' conception of reality, construction of identity, and formation of human values. As the German sociologist Peter Reichelt (1995) provocatively puts it, history culture is always accompanied by a "ruler-legitimizing" dimension. If linked to a perspective which is more concerned with an egalitarian and participatory culture, this point may 
be rephrased as follows: an understanding of the uses of history and a competence in participating in the debates and struggles about memories (i.e. the significance of history and the consequences this entails for our own time) should be considered a condition for active co-citizenship. These problems present themselves in new forms today, since the decisive value-based frame of reference for identity formation and sound judgment is no longer limited to one national dimension. Our sense and understanding of history are today formed in a reality increasingly molded by international connections, transnational structures (the EU) and processes of migration. Seen in this light, the apparent phenomenon that local and other group specific (e.g. religious) identities experience a renaissance can be seen as an expression of a distrust of ambiguity and a need for orientation. Rather than rejecting such tendencies, the theoretical and practical-didactic work should be oriented towards a way of history-mediation which enables individuals and social groups to participate as active citizens in a complex world.

\section{References}

Assmann, Aleida (2004): "Four Formats of Memory: From Individual to Collective Constructions of the Past". In: Christian Emden/David Midgley (eds.), Cultural Memory and Historical Consciousness in the German-Speaking World since 1500, Peter Lang, Bern.

Boëthius, Maria-Pia (1991): Heder och samvete: Sverige och andra världskriget, Norstedt, Stockholm.

Bryld, Claus/Warring, Annete (1998): Besættelsestiden som kollektiv erindring. Historie- og traditionsforvaltning af krig og besættelse 1945-97, Roskilde Universitetsforlag.

Burleigh, Michael (2010): Moral Combat: A History of World War II, HarperPress, London.

Eriksen, Anne (1995): Det var noe annet under krigen, Pax, Oslo.

Erll, Astrid/Nünning, Ansgar (eds.) (2008): Cultural Memory Studies. An International and Interdisciplinary Handbook, de Gruyter, Berlin/New York.

Fure, Odd-Bjørn (1997): Kampen mot glemselen: kunnskapsvakuum i mediesamfunnet, Universitetsforlaget, Oslo.

Grimnes, Ole Christian (1990): "Historieskrivingen om okkupasjonen". In: Nytt Norsk Tidsskrift 2/1990, pp. 108-121.

Levy, Daniel/Sznaider, Natan (2005): The Holocaust and Memory in a Global Age, Temple University Press, Philadephia. 

I Cases of national history Cultures 



\section{Representations of Victims and Guilty in Public History. \\ The Case of the Finnish Civil War in 1918}

SIRKKA AHONEN

\section{History as an ethical project}

During the last two decades history has commonly appeared as an ethical project in the public field. Historical guilt and victimization have been manifested through official apologies by heads of states and, moreover, through claims of financial reparations to those who became wronged in the past. Controversial issues of guilt have been dealt with by the international community in war crime tribunals, as in the case of former Yugoslavia, Cambodia and Rwanda, and by Truth and Reconciliation commissions, as in South Africa and Argentina.

The participation of historians in legitimizing apologies and reparations through their membership in truth commissions has puzzled some other historians, who regard history as an impartial science (Ash 1998). Whereas earlier, since the $19^{\text {th }}$ century, recognition of history as a science, academic and public histories were seen as different fields, historians today widely regard themselves theoretically justified to ask broader questions than in the objectivist tradition of historiography. A. R. Marrus explains the revival of the interest in the Holocaust not only in public history but also in academic research with a change that allows moral perspectives, including questions of guilt, in research (Kalela 2000: 856; Marrus 1987).

Unlike the academic science of history, the social use of history has always been characterized by ethical overtones. The interest in the past among ordinary people is to a great extent founded on the questions of 
guilt (Barkan 2000: XV-XXI). Historical communities identify themselves as victims or as guilty. Representation of victimization and guilt appear in public history, also called the culture of history, which includes collective memories, ritual commemorations, monuments, cultural products and schoolbook texts. The representations may be positively assuring for the members of a community but provocative to others. They may even ignite history wars, as, for example, the heated debates about the schoolbook representations of the Second World War between China and Japan as well as Russia and Poland. In this article, representations of victims and guilt are first studied in theory and then illustrated through an example from Finnish $20^{\text {th }}$ century. The analysis reveals a Finnish way of relating to the past, which may explain Finnish responses to internationally sensitive issues, among them the Holocaust.

"Guilt" and "victimization" as the key terms of this article are derived from the metaphor "history as a courtroom". In a judicial courtroom, the guilty party and the victims are default adversary parties. In the courtroom of history, guilt and victimization are not suggested by a prosecutor, but by fellow members of a community - thus we can speak of an ethics of recognition in relation to the subjects' sense of history or to their historical consciousness. "Guilt" and "victimization" then are here used as cultural representations and studied in regard to their social meaning and use. ${ }^{1}$

\section{Victimization and guilt as tenets of historical identity}

Collective memory is the foundation of the historical identity of a community. Especially in cases of authoritarian and totalitarian rule, a double-faced situation emerges with people using official rhetoric in public and home-fostered history in private. The former communist countries provide examples of such double-talk. In Estonia the Soviet period was called "invitation to the happy family of the Soviet peoples" at school and "occupation" at home (Ahonen 1992: 52, 121).

Collective memory appears as spontaneous vernacular history talk. However, it is inevitably manipulated through hegemonic representations authorized and mediated by those in power. The power-related

1 See also Karlsson in this volume and the understanding of the existential use of history: "The existential use of history is triggered off by the experienced need, felt by all individuals to remember, alternatively to forget, in order to uphold or intensify feelings of orientation, anchorage and identity in a society in a state of insecurity, pressure or sudden change." 
public history consists of official rhetoric, monuments, rites, artifacts and schoolbooks, and its ethos is most often founded on pride in the common past. Most politicians are well aware of the effect of the representations of historical guilt or victimization on the identity of a people. Therefore they often urge educators to emphasize memories that evoke pride rather than guilt among the people. In the 1980s, Helmut Kohl was concerned that the German youth was too frequently exposed to the German guilt for the Second World War; Margaret Thatcher wanted the glorious moments and great men of the British nation to be introduced in the class-rooms; and Ronald Reagan did not like to see his people indulging in national self-bashing instead of bolstering their pride in the past.

Political concern for collective identity tends to trigger history politics by governments and parliaments. In 2005, the French parliament passed a law which ordered teachers to tell their students about the positive achievements of the French colonial rule. Historians reacted by insisting on the freedom of research and education, but also by demanding recognition of historical guilt: " [...] in calling to mind only the positive role of colonization, [the law] enforces an official falsehood about past crimes, about massacres and even genocides, about slavery and about racism". 2 In 2009 the Russian President Dmitri Medvedev appointed a special commission charged with investigating falsifications of history. Lurking in the background of this decision was the denial of the Soviet victory in the Second World War by some liberal publicists, expressed in the context of the celebrations of May 9, "the Victory Day". The commission was asked to defend the history of the Great Patriotic War, as it was taught in schoolbooks. ${ }^{3}$

Vernacular history talk is morally and emotionally loaded. Memories are rather about victimization than guilt. In The Guilt of Nations, Elizar Barkan points out the significance of victimization for the construction of a morally positive identity. Unlike guilt, victimization ennobles people in their own self-understanding. It empowers a community that is in the course of asserting itself as an equal partner of other communities. Minorities within a nation may cherish stories of victimization as means of obtaining recognition (Barkan 2001: 317).

Victimization in collective memory tends to appear as mythical archetypes that are common across different communities. The contents vary but the mode follows archetypes. George Schöpflin has categorized

2 Le Monde, 25 March 2005, quoted in Cajani 2009: 46-7.

3 Helsingin Sanomat, 13 June 2009. 
internationally existing myths of victimization into archetypes of biblical origin. The most powerful types are as follows:

- Myths of redemption and suffering: A community is led to make sacrifices in order to fulfill a God-given destiny and will eventually be redeemed. Various ante-mural myths of fighting for religion belong to this category.

- Myths of unjust treatment. They help a community claim recognition of a special moral worth. The Holocaust tradition is an example of an outstanding success in gaining universal recognition.

- Myths of military valor. Military valor is used to denounce political compromises and justify expansionist politics (Schöpflin 1997: 2834).

Myths mediate both victimization and heroism. The mythical form is convincing, as it implies an ethical solution: good is rewarded and evil punished. Both guilt and victimization acquire meaning as they lead to a righteous result. Myths are about doing the right thing. For a community, popular myths work as collective lessons.

In a political transition, a popular quest for recognition of past wrongs and glories tends to arise and a redesigning of history takes place. To what degree such a quest turns into an ethical or judicial process, depends on the different contexts. According to Timothy Garton Ash, the popular quest is normally restricted to the recognition of the past wrongs, but in many cases straightforward claims of judicial sanctions or even economic reparations are raised. Removals of monuments and revision of schoolbooks are "soft" examples of redesigning history, while truth commissions and special criminal courts are stronger modes of recognition policies (Ash 1998; Evans 2003; Thompson 2002: 26-7, 47, 50-6).

In the course of acknowledging moral claims regarding the past, guilt and praise are attributed to persons and groups. Some are labeled rogues, others heroes. Such attributes redefine the relationships not only between groups within a society but also between a country and the international community. In such a process of reconsidering the past, history wars arise. Recent examples of such wars are the Bronze Warrior war between Estonia and Russia. The Warrior, represented in the monument, was seen as a hero of liberation by Russians and as an evil occupant by Estonians (Torsti 2008: 19-36). China and Japan engaged in a cultural war over schoolbooks, with the Chinese calling for a representation of Japanese as war criminals, while the Japanese chose to leave issues like the Nanking massacre as blank spots in their collective memory. 
Guilt and victimization can be incorporated in collective identities in different modes. Only rarely does a community adhere unanimously to a self-image as guilty. A community rather regards itself victimized, in some cases as a perpetual victim of history. Victimization is felt to ennoble a community, besides often being politically purposeful. Some nations are more inclined than others to regard themselves as perpetual victims. In the following, examples of representations of guilty and victim by a few different communities are suggested.

In "Heavenly Serbia" (1999), Branimir Anzulovic maintains that the Serbs throughout their past have regarded and presented themselves as victims. Serbian folklore is dominated by melancholic themes of victimization. Loss, suffering and martyrdom prevail in stories and songs. Slovenian psychoanalyst V. D. Volkan has studied the subtle ways in which the very private identity of Serbs was manipulated by Slobodan Milosevic at the end of the 1980s. Volkan analyzed the effect of the prince Lazar cult, revived by Milosevic, on Serbian males. According to folk tradition, the prince fell as a martyr of the Orthodox faith in a battle against the Muslims. A martyr is a victim and a hero at the same time. Milosevic let an inscription to be hammered in the pedestal of Lazar's statue, which urged the Serbs to fight the Muslims, adding the curse that those who refused would never be able to conceive male heirs (Volkan 1995).

Another small nation with a dominant victim identity are the Estonians. Ever since they started recording their history in the medieval period, they have portrayed themselves as perpetual victims. In the course of history, German knights, Danes, Swedes and Russians invaded Estonian territory and brought hardships and suffering upon the Estonian people. In their public history, the Estonians lament the victimization. In comparison, the Finns who were likewise invaded and annexed by Swedes and Russians, have found historical pride in their participation in the Swedish $17^{\text {th }}$ century wars and later in their resistance to Russia (Ahonen 2006). The difference in historical identification might depend on reality - Estonia's geopolitical position is awkward - but it also reveals something about the ethos of collective memory. Especially since the 1980s Estonian public history has been characterized by victimization (Ahonen 1992: 101-126).

Among the guilt-stricken nations, Germans are a rare example of a community that has adopted an identity of guilt. For several decades after the Second World War Germans fostered an identity of guilty in their public history. They worked on their Holocaust-guilt actively through drama, film, literature, museums and school education. However, political transitions may alter identities of victim or guilty. In Germany, in the 
atmosphere of the reunification around and since 1990, a revision of history has taken place. In fiction, like in Günter Grass's Krebsgang, the Germans were portrayed as victims. The reconstruction and solemn reopening of the Frauenkirche in Dresden was a sign of Germany's resumption of pride in their history. In 1992, the Germans felt selfconfident enough to criticize the raising of the statue of "Bomber" Harris in London. For Londoners the statue meant recognition of heroism in beating Germany, while for the Germans "Bomber" Harris personified the historical guilt of the British. Since the unification, Germans have emphatically represented themselves not only as guilty but also as victims of the Second World War

The modes of adoption of an identity of guilt or victimhood in the examples above included heroic victimization, resignation in perpetual victimization and the combination of guilt and victimization. As identities are constructions, the modes may vary in the course of time. Variation depends rather on historical context than on national disposition.

In the following, representations of victimization and guilt are analyzed in the case of the Finnish Civil War of 1918. After four generations, the war is still being used in the identity struggles among the Finns. Victimization and guilt are contested over the borderline between the political left and right, even if in the present politics the borderline is becoming more and more blurred.

\section{The Civil War as the most tragic chapter of Finnish history}

In order to suggest how far the Finns, in their public history, represent themselves as victims or guilty, I will first identify the most sensitive topics of the $20^{\text {th }}$ century and then focus on the most difficult of them. I define a topic as sensitive, if it divides people into adverse communities of historical interpretation. If a topic is sensitive, there are at least two stories of it, one of victimization and one of guilt. If one story was silenced in public for a period it is most likely to indicate guilt.

According to the testimony of Finnish public history, the most sensitive topics are constituted by the Civil War of 1918 and its aftermath, the Second World War alliance with Nazi Germany and the Finnish contribution to the Holocaust, and, finally, by the Finlandization of the 1970s, meaning an opportunistic appeasement of Moscow by the Finns. The guilt and victimization due to the civil war is the most complex of these topics. I will focus on the civil war, while the Finnish Holocaust is treated in the chapter written by Tom Gullberg in this book. For many dec- 
ades, the Finns indulged in the identity of a community that defied the Germans and protected the Jews, but as late as 2000 they had to admit that the Finnish war cabinet took part in the Holocaust, even if indirectly and in small numbers. Finlandization is a very recent painful element of Finnish historical identity. Apart from feeling shame for having kept silent about the dark side of the Soviet system, Finns admit to the guilt of having adopted a bystander attitude in regard to the plight of Soviet dissidents.

Compared to the sensitive topics of the Second World War and Finlandization, the Civil War of 1918 is a deeply divisive episode in the Finnish social memory. Even in the first decade of the $21^{\text {st }}$ century, old people in some parts of the country still feel hatred towards their neighbors on account of having been on different sides in 1918 .

Finland had declared itself independent in December 1917, but not on a unanimous basis, as a part of the people preferred a socialist revolution. The Civil War between socialist Red Guards and bourgeois White Guards started in January 1918, lasted three and a half months and resulted in the victory of the Whites. The death toll was around 30000 , including deaths due to civil terror and postwar concentration camp atrocities. Acts of terror were committed by both sides. At an early stage of the war, the country was divided into White and Red territories, and both the White Army and the Red Army wanted to secure their territories against enemy infiltration. The hostile elements in the local population were controlled, detained and cleansed. As the military strategic purpose on its own does not suffice to explain the extreme cruelty and the excessive killings of civilians, the social attribution of victimization and guilt deserves a critical study.

The contradictions in the Red and White history are evident in the disagreement over how the war of 1918 should be called. The disagreement has prevailed until today. In the working class tradition, the war is called a civil war, a class war or a war between brethren, while among the bourgeoisie it is referred to as a fight for freedom, which indicates a war in the defense of independence.

\section{Attribution of victimization by the parties of the Civil War}

The Red victimization was emphasized by the far larger numbers of casualties sustained by the Reds in the conflict in comparison to those of the Whites. The Reds suffered massively, especially due to the revenge after the war, known as the White terror. The victims of the White terror 
amount to 10000 , compared to the 1600 victims of Red terror. No wonder then that the social memory of the working class became characterized by victimization.

Due to the mass killings of civilians and prisoners of war, Reds called the White guards "slaughterers". Rhetorically, many terms used by Reds were derived from the Communist Manifesto and Marxist theory. The theory was translated into powerful vernacular expressions, many of which were familiar to people from the archaic biblical language. The workers represented themselves as victims of "exploiters", "bloodsuckers", "robbers" and "oppressors". The morally charged terms indicated an antagonism between capitalist owners and socialist workers (Hyvönen 1977: 96-106; Manninen 1982: 169; Tikka 2008:71).

Apart from being victims of the owners' class, the Finnish working class regarded itself as victims of a political betrayal by the bourgeoisie. The parliament with a socialist majority was dissolved in July 1917 through a joint decision by the Russian Provisional government and the Finnish bourgeois parties. The socialist voters, empowered by the successful Bolshevik revolution in Russia, considered themselves betrayed and justified to refuse loyalty to the new, bourgeois-dominated Parliament (Hyvönen 1977: 30-34).

Another betrayal, according to the socialists, took place when the bourgeois government promoted the White paramilitaries, the Civil Guards, to the status of the official Finnish army. The socialist leadership interpreted this as an attack against the working class and proclaimed a Red revolution (Hyvönen 1977: 97). In the consequently divided country the workers became victims of the White Army's military cleansing policy. When the White Army progressed to the Red areas, the Reds were hunted down, punished and executed by the White Guards. Every workers' union member and supporter became a suspect and an enemy to be eliminated.

After the war ended in May, the cleansing policy was intensified. Altogether 80000 Reds were locked up in concentration camps, which were portrayed as death camps by the inmates. The deaths were mostly due to the inhuman conditions in the camps. Reds died of hunger and epidemic diseases.

For long after the war, members of the working class were suspected of rebellious intentions. The witch hunt against Reds continued for years. Acts of terror continued and were reinforced by the rightwing extremism of the 1930s. In social memory, the Finnish working class regards itself a victim of extended White terror.

The White victimization was based on the Red terror, reinforced by an ideological Red scare. White Finns regarded themselves as victims of 
a primitive Red rage. The rhetoric of the "monstrous" lower class spread universally in Europe as a by-product of a political fear of socialism. The rhetoric was articulated by Gustave Le Bon in his popular La psychologie des foules, which was translated into Finnish and widely disseminated among the bourgeoisie in the 1910s. In the emerging White rhetoric, workers were portrayed as rogues who had no sense of law and order and a tendency for cruel violence. The actual Red terror included breaking into manor houses, killing the owners in front of their family, sit-ins in factories and distributing leaflets containing death threats against bureaucrats and big capitalists. The $19^{\text {th }}$ century paternalist picture of rural poor as dependents who had to be both protected and disciplined, gave way to a picture of workers as alien and hostile masses against whom the civilized people had to defend themselves.

The White victimization appeared as grim austere torture stories. Especially if the victim was a clergyman, the Red perpetrator was demonized. The number of stories about tortured priests increased after the war and indicated a great fear and deep disgust of Reds among the bourgeoisie. The presence of women among the Red Guards was regarded by the bourgeoisie as particularly offensive to their sense of decency (Manninen 1982:121, 160).

The Whites considered themselves victims of a betrayal by fellow countrymen. Finland had finally gained independence. For Whites, the Red attack against the young nation-state was an incomprehensible blow against the civil code, according to which people should be able to trust their compatriots. The socialists had betrayed the nation by resorting to revolution and accepting support from Russian Bolsheviks. According to the White propaganda, the Reds were fighting their fellow countrymen with Russian bayonets (Manninen 1982). According to the White view, the countless death sentences pronounced by White military tribunals at the end of the war were an act of self-defense by the victims of anarchy (Tikka 2006: 154).

\section{Attribution of guilt to the parties in the Civil War}

Guilt was attributed to the Reds by the adversary party, the Whites. In the aftermath of a war the defeated tend to be treated as guilty and the victors as innocent. In the case of the Finnish Civil War, the White military and special tribunals charged, tried, and sentenced Reds, while investigations into the White terror were few and mainly nominal. In ver- 
nacular discussion the issue of guilt was handled more symmetrically. Both parties memorized and mythologized each other's evil deeds.

Attribution of guilt as a way of making sense of past events evades structural explanations. Instead of accounts of institutional evil, guilt is attributed to persons or groups. In the case of the guilt of Finnish Reds in the Civil War of 1918, the guilt was attributed to barbaric masses, bloodthirsty leaders and ruthless local Red Guards.

The accusation of low-class masses being barbaric was elaborated by a popular contemporary author Eino Leino as follows:

"[The rebellion] released all passions, lifted guns against legal government and parliament, felled all courts of justice and civil institutions, spread blood and death, deadly horror and red destruction (hävitys) into the most far-away forest settlements. It was like letting the devil free.” (Kunnas 1976: 102)

Accusations of barbaric bloodthirstiness and bestiality were presented in the media, in military tribunals, in public registers and in the official declarations by the Commander-in-chief C. G. E. Mannerheim. According to the communion register held by the church in the parish of Akaa, an unemployed worker, Juho Viktor Vuori, was executed "as one of the biggest monsters of the Red terror" (Tikka 2006: 148). In his address to the Finnish people at the triumph parade on 16 May 1918, Mannerheim praised the White Guards for having defended what was most dear to the Finnish people and had been threatened by the Reds, namely their religion, their fatherland and the home inherited from their ancestors (Manninen 1982: 117).

The adversary party, the defeated Reds, attributed guilt to the Whites. The issue of White guilt was raised immediately after the war; the accusations were triggered by the massive numbers of executions ordered by the White military tribunals, but the outcry was soon stifled and the accusations against the Whites silenced or left to underground socialist publishing and vernacular history.

In the socialist rhetoric, the owners' class, supported by the state bureaucracy, bore the guilt for the exploitation and oppression of the working class in general. In the Civil War, the White guilt was, according to socialist publications, shared by the oppressive White senate, "slaughterer-general" Mannerheim, terrorizing White Guards and unjust military tribunals (Hyvönen 1977: 83-128). After a month's fighting, with the White army having advanced into Red Finland, the White headquarters issued the order to shoot dangerous suspects "at sight". The killing was executed by military tribunals and specially appointed war police contingents consisting of White Guards. Moreover, individual White 
Guards shot unarmed Reds after taking them prisoner (Tikka 2006: 36, 121-2). "White terror" and "slaughterers" became the core of Red accusations.

The concentration camps finally became the most illustrative part of the White guilt. Already after the first victories of the White army the attitude of the Senate towards the Reds hardened. As no detainees were set free, the camps swelled. The biggest camps were Suomenlinna (13 300 prisoners), Hämeenlinna (11 5000), Lahti (10 900), Viipuri (10 350), Tammisaari (8700) and Tampere (8 700). The camp barracks had not been designed for the growing numbers of prisoners, which led to prisoners being accommodated in animal shelters, floorless cellars and earth holes. The administration of the camps was left to the White Army, namely to the Department of the Protection of the Conquered Territories. The White Guards functioned as commanders and subjected the inmates to harsh military discipline. The camp wards, judges, and bureaucrats in general were regarded by socialists as bearers of class hatred. The judges were guilty of executing bourgeois justice and the bureaucrats of harassing the poor (Tikka 2006).

The concentration camps were criticized by foreign Western governments as an insult to the rule of law. The Finnish government responded by maintaining that the camps were a Finnish internal affair (Pietiäinen 1992: 353).

The memory of the concentration camps became a divisive element in the Finnish historical identity. Tens of thousands of Red families adopted the identity of victims, while the Whites took a pride in the righteous victory and repelled accusations of guilt.

As a whole, Red and White representations of history support Schöpflin's view of the use of mythical archetypes for the claims of guilt and victimization. The "myth of redemption" is present in the argument invoked by the Whites, according to which their victory saved Finland from chaos and barbarity. The "myth of unjust treatment" was used by the Reds when referring to the bourgeois exploitation in the past and to their snatching away political power from them by dissolving Parliament in 1917. The "myth of military valor" was utilized by the Whites in stressing the purity of their struggle for freedom and in justifying their postwar terror with their right to secure their righteous victory. 


\section{The aftermath of the Civil War}

In the politically divided Finnish society of the 1920s and 1930s the attribution of guilt and victimization was diagonally adversative. The victorious bourgeois state idolized the White victims. During 1920s more than 300 monuments were raised in their honor. A monumental memorial publication from 1927 was financed by the Parliament and presented the life stories of the 5000 fallen White Guards (Boström 1927). In schoolbooks the war was portrayed as a freedom fight, implying that the aim of the Reds was to make Finland a part of the Soviet Union. Memory of the war was used to fuel the Red Scare of the time (Rouhiainen 1974). The public history was dominated by manifestations of the White victory. Monuments for the white "freedom fighters" were raised in the local cemeteries, while red victims were left buried unnamed in mass graves. In the mainstream culture, doubts about the White truth were expressed only by a few authors like Frans Emil Sillanpää, Joel Lehtonen and Jarl Hemmer.

Even though a few reconciliatory political gestures were attempted by the centrist governments just after the war, the plight of the Reds was perpetuated by the discriminatory social atmosphere of the 1920s and 1930s. Only 11 monuments for the Red victims were raised during that time. In most cases they were dumped in the outskirts of towns and villages (Peltonen 2003: 222-3). When in 1923 a local workers' union in Hämeenlinna raised a monument to the Red victims in a churchyard, the ones responsible were charged with subversive activities. The church denied the right to commemoration, and the monument was destroyed by the police. ${ }^{4}$ However, in socialist publications and vernacular working class tradition, the memories of the Red sacrifices in the Civil War were cherished, often as half-mythical stories of Red heroism and White evilness.

After the Second World War, under the auspices of a short leftist wave in politics, public commemoration of the Red victims gathered momentum. Parliament urged the government to care for the neglected graves of the Reds. However, a true public recognition of the plight of the Reds only came as late as the 1960s. In big public burials, with clergymen speaking of guilt and reconciliation, the exhumed remains of the Reds were reburied in churchyards. Monuments were raised for those who had "died for their ideological conviction" (Peltonen 2003: 226-8). Moreover, in the 1960s the public was ready to accept schoolbooks, where a balance was pursued, with authors accounting for the Red upris-

4 Helsingin Sanomat 14.5.2006. 
ing in terms of social distress, and editors making sure that equal numbers of Reds and Whites appeared in illustrations.

In the mainstream culture a change took place thanks to the novelist Väinö Linna. His monumental novel Täällä Pohjantähden alla (Under the North Star) opened the issue of guilt. The Reds were portrayed as victims, not as guilty, and the Whites as perpetrators. Following Väinö Linna, theatres and film studios adopted the Red perspective. The productions were attended by massive audiences and greatly affected Finnish collective memory.

Apart from an attempt to deal with a collective guilt, the Finns of the 1960s and 1970s used history to fuel political antagonisms. In many municipalities, the raising of a monument for the Red triggered an equivalent quest among the political Right. As a result, equal numbers of monuments were built for the White and Red Guards in the period. As the political contest between socialists and non-socialists was fierce, historical guilt was used to bolster political identities.

At the turn of the new millennium, the Civil War is nearly five generations back in time, but facing up to the disaster is still a regular need at the war's anniversary. The ethos of the commemoration is today less political than in the 1960s. People seem to think more in terms of transgenerational ethics. The generation of 1918 deserves to be done justice to. A comprehensive survey was conducted by the state at the turn of the new millennium in order to establish the true numbers of the victims on both sides. The numbers were not radically different from those already confirmed by research in the 1960s, but they helped many Finns to escape inertia about the collective historical identity and forced the establishment to acknowledge a historical wrong. Since the turn of the new millennium, the leadership of the church has officially expressed remorse for taking the White side in 1918. Already in five dioceses the bishops have organized solemn burials for the Red victims exhumed from hidden mass graves in the forests. As late as in 2006, in the middle-sized city of Hämeenlinna, in the center of the region worst stricken by the war, a burial of 3500 exhumed Reds took place under the auspices of a public recognition of guilt by the church, personified by a bishop who held the service and gave a sermon on reconciliation. A suggestion was made - even if not yet materialized - that an annual day of reconciliation should be included in the calendar of commemorations.

In 1997 I conducted a research into the historical identity of young Finns. When asked about the Civil War, they did not express any feeling of transgenerational guilt. According to them, it was necessary to remember and recognize the tragedy but not to attempt reparation (Ahonen 1998: 67-73). However, the testimony of public history is different. Vic- 
timization and guilt continue to be reified in fiction, monuments and rituals. The past is not dead; it is not even past.

\section{Conclusion}

In this article I have explored the use of history as an ethical project in the sense of addressing the question of moral recognition. ${ }^{5}$ The concepts of guilt and victimization can be seen as constitutive of such a process of recognition, not least in the sense of construction of a sustainable collective identity.

Finns do not belong to the communities that would strongly identify with historical victimization. They rather tell their history as a story of tough survival. Nevertheless, Finns are burdened by some difficult episodes of history, above all by the tragedy of a civil war, which, together with its aftermath, kept people divided for decades. Public history, including monuments, commemoration rituals, literature and art as well as school books seem to keep the history alive for new generations.

There was no attempt at reconciliation after the Civil War. Therefore the horrors were left as an open wound in the collective memory. Even though the Finns have felt ready to face up to the difficult past since the 1960s, the interpretations have fluctuated from pro-Red to Pro-White, sustaining mutually exclusive group identities, and an open dialogue of healing between the two memory-communities has only slowly been established. In a deliberative dialogue, mutual accusations would be accommodated and victimization acknowledged. Collective identity would become inclusive instead of consisting of mutually exclusive subidentities.

What does a redesigning of collective identity depend on? Having looked at the representations of guilt and victimization in the context of the Civil War, I suggest two factors: popular political will and a trickledown of academic research.

Collective recognition of the guilt of the atrocities of the Civil War was triggered by the leftist turn in politics in the late 1960s. Apologetic rhetoric and demonstrative burials of Red victims spread after the socialist parties won the majority in the parliamentary election in 1966. Since a rightist turn in the 1980s, some rehabilitation of White perpetrators has taken place. However, the political will to bring the descendants of Reds and Whites together at a common round table is still missing.

5 Ethical should here be understood in the Hegelian sense where "one becomes an individual subject only in virtue of recognizing, and being recognized by, another subject" (Fraser 2003: 10). 
Academic research was long divided along the lines of the war, but during the last two generations a genuine contribution has been made by historians to help Finns confront the events of 1918. The works of Jaakko Paavolainen in the 1960s sorted out the numbers of victims on both sides and put an end to the game of inflated numbers concerning the amount of victims and suffering. The numbers were counted again in the course of state-supported extensive research in the 1990s. The hard facts are there for a mutual acknowledgement of victimization and guilt, as soon as the Finnish community wants to redesign its identity in terms of inclusiveness.

The case of the Civil War shows how the "awkward" or conflictive past was dealt with by means of a long silence, based on pragmatism. And when the history of the Civil War was addressed, it happened within the fixed terms of heroism and of victims and guilty. This way of dealing with the past may be compared to the way in which the legacy of the Holocaust was dealt with within the national history culture of Finland. Up until the 1980s, a self-righteous - or heroic - image of Finland as protector of the Jews during the Second World War dominated public perception. Only when the question of guilt in relation to the Holocaust reappeared in an international context, did a Finnish discussion arise on the role played by the Finnish state. As an outcome of this discussion, the Finnish national identity as a victim of great power aggression was modified by the acknowledgement of how the Finnish state carried out decisions and actions which, at the very least, failed to avert further persecutions of Jews, both before and after the outbreak of war (see the contribution by Tom Gullberg for an elaboration on this issue). In that sense the themes of victims and guilty were played out once again within national history culture, but this time with a shift within the position of the Finnish state.

\section{References}

Ahonen, Sirkka (1992): "Clio Sans Uniform. A Study of the PostMarxist Transformation of the History Curricula". In: East Germany and Estonia. 1986-1991, Annales Academiae Scientiarum Fennicae B: 264.

Ahonen, Sirkka (2006): “Att ta ansvar för det förgångna. En jämförelse av historiekulturer i Estland och Finland”. In: Annika Alzén/Peter Aronsson. Demokratiskt kulturarv? Nationella institutioner, universella värden, lokala praktiker, Linköpings universitet, Tema Kultur och Samhälle, Skriftserie 2006, pp. 21-36. 
Anzulovic, Branimir (1999): Heavenly Serbia, From Myth to Genocide, Hurst \& Company, London.

Ash, Timothy Garton (1998): "The Truth About Dictatorship". In: New York Review of Books 19.2.1998.

Barkan, Elazar (2001): The Guilt of Nations, Restitution and negotiating historical injustices, The John Hopkins University Press, Baltimore.

Boström, H. J. (1927): Sankarien muisto [The memory of the heroes], Suomen sukututkimusseura, Helsinki.

Buruma, Ian (2002): The Wages of Guilt: Memoirs of War in Germany and Japan, Phoenix, London.

Cajani Luigi (2009): "Historians Between Memory Wars and Criminal Laws: The Case of the European Union”. In: International Society for History Didactics, Yearbook 2008/09.

Fraser Nancy (2003): "Social Justice in the Age of Identity Politics: Redistribution, Recognition and Participation”. In: Nancy Fraser/Axel Honneth (eds.), Redistribution or recognition?: a political-philosophical exchange, Verso, London.

Hyvönen, Antti (1977): Suurten tapahtumien vuodet [The years of great events], Kansankulttuuri, Helsinki.

Kalela, Jorma (2000): Historiantutkimus ja historia [Historical research and history], Gaudeamus, Helsinki.

Manninen, Turo (1982): Vapaustaistelu, kansalaissota ja kapina [Freedom war, civil war and rebellion], Jyväskylän yliopisto, Jyväskylä.

Marrus, Michael Robert (1987) The Holocaust in History, University Press of New England, Hanover, NH.

Peltonen, Ulla-Maija (2003) Muistin paikat.Vuoden 1918 sisällissodan muistamisesta ja unohtamisesta [The places of memory. Remembering and forgetting of the civil war of 1918], Suomalaisen kirjallisuuden seura, Helsinki.

Pietiäinen, Jukka-Pekka (1992): "Suomen ulkopolitiikan alku" [The beginning of Finnish foreign politics]. In: Itsenäistymisen vuodet 1917-1920 3, VAPK-Kustannus, Helsinki, pp. 252-470.

Rouhiainen, Pirkko (1974): "Historian koulukirjat mielipiteen muodostajina maailmansotien välisenä aikana" [History textbooks as opinion-builders in the inter-war period]. In: Historiallinen aikakauskirja 4/1974, pp. 298-313.

Schöpflin, George (1997): "The functions of myth and a taxonomy of myths". In: Geoffrey Hosking/George Schöpflin (eds.), Myths and Nationhood, C. Hurst \& Co, London.

Thompson, Janna (2002): Taking Responsibility for the Past. Reparation and Historical Justice, Polity, Cambridge. 
Tikka, Marko (2008): Terrorin aika. Suomen levottomat vuodet 19171921 [The age of terror. The restless years of Finland 1917-1921], Gummerus, Jyväskylä.

Torsti, Pilvi (2008): "Why do History Politics Matter? The Case of the Estonian Bronze Soldier". In: Juhana Aunesluoma/Pauli Kettunen (eds.), The Cold War and the Politics of History, University of Helsinki Department of Social Science History, Helsinki, pp. 19-35.

Volkan, V. D. (1995): "Kosovo. Transmissions". A paper at a psychoanalytical seminar in Helsinki, December 1995. 



\section{The Holocaust as History Culture in Finland}

\section{TOM GULLBERG}

The Holocaust has in the post-Cold War era provided different societies with the possibility to discuss and debate their historical development in the $20^{\text {th }}$ century. The Holocaust means different things in different states. For states like Germany and Israel that have been directly involved and affected, a historical debate about the Holocaust constitutes at the same time a reflection on their own national identity. In these cases the Holocaust has activated a political and identity-based historical and actual interest (Karlsson/Zander 2006).

For states like Sweden, that was not directly involved, the debate has been more ideological, and focused on themes such as values and human rights, but also on the basic subject competence of history. During the latter part of the 1990s this perspective was connected with the debate of Neo-Nazism and skepticism and Holocaust-denial. Here, the post-Cold War debate has had a strong focus on moral and values, and has involved also other genocides than the Holocaust. ${ }^{1}$

Several studies have been published about the reasons for making the Holocaust the most important object in the debate of historical identity and historical consciousness in the post-Cold War Europe. In this article I restrict myself to Finland and the Finnish historical discussion or non-existing discussion - about the Holocaust. Nevertheless, also the Finnish case must be related to the general context, not only of the postCold War debate, but also to the general context of post-Second World War debate in Europe in the era after 1989.

1 For example Rosenbaum 2001 and Gerner/Karlsson 2005. 
The leading argument in this article is that the Finnish silence in relation to the Holocaust must be understood in the context of some more tragic, sensitive and complex aspects of Finland's own history, or at least how some of these historical phenomena have been interpreted in the historical debate during the last decades.

The general (Western) European discussion during the 1990s about Holocaust-deniers and Neo-Nazism was also introduced in Finland, but the question never grew into such a big political issue as in Sweden. While Sweden became a world leader in the new international debate on the Holocaust, Finland handled the newly arisen interest in a more formalistic way as a technical issue for the National Board of Education. Especially Swedish-speaking schools in Finland were also at quite an early stage inspired by some didactical models from Sweden (and Norway), as for example the White Buses-projects and the Swedish school book "Om detta må ni berätta" (also in English with the title "Tell ye your children"). The book was later translated into Finnish with a shorter supplement, on the initiative of the National Board of Education. ${ }^{2}$ The supplement is related to the debate in Finland in 2000-2001 about the expulsion of eight Jewish refugees to Germany, and further on to Auschwitz-Birkenau (Bruchfeld/Levine 1998; Bruchfeld/Levine 2001). I will return to that debate later in this article, but it is interesting to note that a national authority was eager to explain, and in some extent even to contend the official version of what really happened in Finland during the War. I will argue that this is quite illustrative for the Finnish historical debate of Finland's role in World War II during the period 19411944 in general, and for the relation to Nazi Germany in particular (Sana 2003).

Like all the other members of The Council of Europe, Finland has celebrated the $27^{\text {th }}$ of January as the Day of Remembrance of the Holocaust and the Prevention of Crimes against Humanity since 2001. Still, the reason for flying the flag that day seems to be quite unknown to the

2 Since the first constitution in 1919 of the newborn Finnish sovereign nation-state, the state has had two official national languages, Finnish and Swedish. Swedish is spoken as mother tongue by approximately 6 percent of the population (about 300,000 people). Both language groups have their own distinct and independent school systems, at least when it comes to school cultures, although the curricula and school laws are shared by both language groups. It is compulsory for every student to study the other national language in school, which should guarantee some kind of functional bilingualism. Fluency in both languages is required for work in state service, and also in officially bilingual municipalities (official bilingualism is reached when the minority language is spoken by $8 \%$ of the population, or has reached a number of 3000 persons). For a contemporary overview, see Sjöholm 2004 and Hansén 2004. 
majority of the citizens of Finland. No official declaration about the reasons behind flying the flag has been made on that day, apart from the situation in many other European states. But, as has been mentioned many times in the academic discussion about the Holocaust in modern historical culture, the Holocaust is today an entry ticket to European values and identity, which was something that Finland actively strove for (Karlsson 2008; Levy/Sznaider 2006).

In comparison with Sweden, and also partly in comparison to the other Nordic countries, there seems to be a more remarkable political silence in Finland, especially in relation to the debate of the co-operation with Germany during World War II. The reason for the unwillingness to discuss the Holocaust theme has to do with the degree of involvement in the war. Sweden was indirectly involved through the active "nonmilitary" co-operation with Germany, but Sweden was not occupied, as was the case with Norway and Denmark, and did not fight side by side with Germans at the front, which was the case with Finland during the period 1941-1944.The co-operation with Germany seems to be more politically sensitive than could be expected over a half decade after the war. An example of this sensitivity is the reaction that was provoked when the Swedish journalist and writer Henrik Arnstad during the autumn of 2006 tried to discuss Finland's close co-operation with Germany from a moral point of view. The core of Arnstad's argumentation was that Finland's choice of side was immoral and that Finland in reality fought for the same goals as the Third Reich. These reflections were very eagerly attacked by nationally oriented Finnish war historians (Forss 2006). It seems that it is more comfortable to play down the cooperation with Germany than to reflect upon what the co-operation looks like from a post-Cold War perspective.

The history of Finland involves all the crucial keywords that make an open discussion about the Holocaust sensitive. Finland has its own history of concentration camps, massacres and expropriations, and may therefore not have the same access to moralize about the inhuman actions during the World War II.

\section{The Finnish Civil War}

One of the crucial historical events that have had consequences for the attitudes today towards the discussion of the Holocaust is undoubtedly the Finnish Civil War during the spring of 1918. The Civil War is still a very sensitive event to handle in the Finnish political and historical debate, and also in history education in school (The article by Sirkka Aho- 
nen elaborates the question on the relationship between the legacies of the Finnish Civil War and the Holocaust). One of the more delicate questions is connected to the naming of the event: "Civil war" is said to be the most neutral name, although it indicates that it was a war between two different political and ideological parties of Finnish citizens. For some right-wing "White" groups it is still important to talk about the "Freedom War", to mark that it was first and foremost a war against Russian bolshevism and a war for freedom from Russia. For some more left-wing "Red" groups it is, on the other hand, still important to describe the war in terms of a class struggle.

Irrespective of the name of the war, the Civil War is still a trauma in Finnish debate, not least from a human rights perspective. Terrorism, in the form of executions and both mental and physical torture, was common on both sides during the war, although the victorious White party's vengeance after the war is more known and debated. The documentation of different mass executions and massacres has been intensified since the 1990s, after being denied and silenced during many decades. The World War II and the more complicated relations to the Soviet Union did not make the discussion about these actions easier.

Besides massacres and executions, a prominent feature of the period immediately after the war were the concentration camps holding Red prisoners. About 50000 Red soldiers or sympathizers were taken prisoner in May 1918, and the only available places to keep such a huge amount of people were at the evacuated Russian garrisons. The most infamous of the Red concentration camps - because of the high mortality - were those in the fortress of Sveaborg outside Helsinki and the garrison Dragsvik in Ekenäs, today functioning as the Swedish-speaking brigade of the Finnish army. The official reports for Dragsvik states that the camp had a total of 9313 prisoners, of which over 3000 died. The biggest mass grave in Finland is situated just outside Dragsvik. Most of the prisoners died of hunger, although hundreds were also executed (Lindholm 2005). Even though the grave was well-known by the older local inhabitants, the first official memorial at the place was not dedicated until 1988.

In the history culture of Finland a debate about historical inhuman actions, such as the Holocaust, easily turns into a discussion about inhuman actions within Finland. Mass graves, concentration camps and executions during the Civil War were not a part of the national success story. The Holocaust comes too close to the national trauma - and the non-usage of history has been the most-used method for avoiding painful discussions, not least on an international level. 


\section{Expulsion of Jews}

One of the most sensitive questions in the Finnish World War II debate is, not surprisingly, the Jewish question. For several hundred years Finland had a small Jewish minority, which was well integrated into Finnish society, and with full religious rights. The Jewish minority was immediately entitled to vote when the universal suffrage (for men) was introduced in 1906. Like other minority groups, the Finnish Jews also served in the army during the war, both in the Winter War of 1939-1940, and in the Continuation War - in collaboration with Germany - in 19411944. This meant that Jewish soldiers in the Finnish army were under the risk of being confronted with German Nazi officers, a situation that actually occurred several times.

The Finnish government and army officers' defense of the Jewish minority is well documented, and it has been politically unproblematic to discuss the position of the native Jewish minority during the war. A crucial detail of the debate is connected to the group of Jewish refugees that arrived from Germany to Finland. As early as 1970 the journalist Elina Sana (Suominen) described how eight Jewish refugees were sent back to Germany in 1942. She could track the refugees, of whom two were children, to the concentration camp in Auschwitz. Her book "Kuolemanlaiva S/S Hohenhörn - juutalaispakolaisten kohtalo" (The Ship of Death S/S Hohenhörn - the Fate of the Jewish Refugees) was considered a very impressive academic work - it was even awarded the information prize of the state - but the issue was very sensitive, not least from a political perspective (Suominen 1979). Despite the encouraging critic of Sana's book, it did not result in a more visible debate about Finland's policy in relation to the Jewish refugees. ${ }^{3}$ The expulsion of Jews was politically sensitive in a double sense. It was painful for both Finn-

3 This has been a general trend in the discussion of sensitive historical issues during the Cold War era in Finland: It has been possible to research in even very politically sensitive topics in narrower academic circles, the results have been made public, but a debate in a broader sense has been toned down. There has never existed any form of formal censorship, but editors and politicians have - in the politically very sensitive environment of the Cold War - not been very eager to debate sensitive aspects of national history in the public sphere: it was more important to take the sensitive relation with the Soviet Union into consideration. Therefore results of research from the 1970s could again be considered as "sensations" 40 years later. The Finnish use of concentration camps during the Continuation War is a good example of this phenomenon. Antti Laine wrote about the camps in his dissertation as early as 1982, but Henrik Arnstad (2009) could nevertheless write about the camps in his new book as if he was coming out with hitherto unknown facts. 
ish historians and politicians to publicly discuss an act that in the 1970 s was deemed as both politically and morally wrong. But the question of the expulsions also had a connection to the politics of 1979. When the first Austrian refugees of Jewish origin arrived at Helsinki on the ship Ariadne in the summer of 1938, the government and its minister of civil affairs, Urho Kekkonen, were implementing a very restrictive policy towards refugees. The refugees from Ariadne were allowed to stay in Finland, but the reason why remains unclear. One theory is that the Finnish consulate in Vienna had stamped a visa in the passports of the refugees without consulting the government. Still, the next ship that arrived with 53 refugees four days later was immediately sent back to Stettin. It is said that this happened on the direct order of the minister of civil affairs. These refugees, of whom some of them are said to have committed suicide, were later called "Kekkonen's Jews" by different historians. One outspoken motive for the government's policy at that moment during the war was to avoid "a Jewish question" in Finland.

In 1979, Kekkonen was already a legendary figure and president of the Republic of Finland, so the political climate did not lend itself to speaking openly about the Finnish actions towards Jewish refugees during World War II. At the end of the 1970s, President Kekkonen was considered to be the only political leader capable of handling the sensitive relations with the Soviet Union, which made it politically expedient to leave his reputation untarnished. This might be the main reason for toning down the academic discussion about the Jewish refugee-question during the War. ${ }^{4}$

\section{The collaboration with the GESTAPO}

Sana's book about Jewish refugees (1979) was quite eagerly criticized both by politicians and nationally oriented historians, and her audience was almost even more critical in 2003, when she followed up with the book "Luovutetut - Suomen ihmisluovutukset Gestapolle" (The Extradited - Finland's extraditions to the Gestapo), in which she describes the relation between Communism, Jewish ethnical background and extraditions (Sana 2003). Her theories about direct contacts between the Finn-

4 This so called "Finlandization aspect" was discussed in relation to historical research as early as 1991 by Timo Vihavainen. The concept "Finlandization" is generally understood to mean the Finnish adaptive policy in relation to the Soviet Union, characterized by informal ways of selfcensorship and a tendency not to criticize the policy of Moscow. 
ish Secret Police (VALPO) and its German counterpart the GESTAPO were too sensitive even in 2003.

On an academic level, the dissertation of Oula Silvennoinen (2008) on wartime relations between the secret police in Finland and in Nazi Germany seems to have started a more open and critical debate, although the theme is still regarded as politically and morally sensitive. Silvennoinen has been able to describe the growing co-operation between the two secret police organizations in a very convincing way. $\mathrm{He}$ quite laconically notes that the VALPO had to strengthen the cooperation with the GESTAPO in 1941 due to political reasons, with the aim to be perceived as a good ally. On the other hand, he also notes that several high-ranking figures in the VALPO had right-wing leanings, indicating how it might not have been so difficult for them to take such a radical step. The co-operation seems to have been very pragmatic during the war - sources confirm that the Finnish army systematically sent over Soviet war prisoners to the Germans, in several cases with the direct aim to execute the representatives of a common enemy (Silvennoinen 2008).

During the Cold War, Finland was handed over from the influence of one dictatorship to another, from Berlin to Moscow. From this point of view it is quite obvious that it was, not least on a political level, not very easy to debate the wartime relationship between Berlin and Helsinki in the new Cold War atmosphere. The handing-over of Soviet prisoners to the Germans was considered to be a war crime, and was not the most convenient issue to discuss with the Soviet leadership in the context of the problematic Finnish-Soviet relationship after the war.

In connection with the debate on the infrastructure of the Holocaust, it must also be mentioned that the Finnish authorities undoubtedly sent about forty Jewish refugees to build fortifications in Salla and the railway line to Kemijärvi. This is also mentioned in the supplement of "Tell ye your children", but in the text from the National Board of Education it says that "it is, in retrospect, difficult to understand why these Jewish refugees were sent up to the north as a labor force" for the German troops. Sana had a straight answer to that question already in her book from 1979. She mentioned that in July 1942 the minister of civil affairs, Toivo Horelli, had admitted that the reasons behind the measures were purely political.

In the supplement of "Tell ye your children" the co-operation between Finnish and German secret service authorities is not discussed at all. A general tendency in the Finnish historical debate is to tone down the active relationship between the Finnish secret police (VALPO) and its German counterpart, the GESTAPO. Elina Sana is almost the only one who has attempted to discuss those connections since the 1970s, and 
for that reason she has obviously not been very popular in leading political circles.

\section{Concentration camps in Eastern Karelia}

As already mentioned earlier, the co-operation with Nazi Germany is still a very sensitive issue in Finland. The establishment and use of concentration camps by the Finnish army during the Continuation War 1941-1944 has made the connections to German war history and the Holocaust even more painful, and an open discussion about the Holocaust even more difficult.

During the autumn of 1941, the Finnish troops launched a powerful offensive into Soviet Union's Eastern Karelia, subsequently occupying Soviet territory. The military commander Mannerheim had beforehand given instructions on how the local Russian population was to be dealt with. It was clearly pointed out that the Russians should be detained and placed into concentration camps, and these were also established. The Finnish military authorities used the concept of concentration camps, which complicates the discussion of the possible links to the Holocaust even more. Every ten years, there is a surge of sensational articles about the Eastern Karelian concentration camps - "never exposed before" and after a brief rush of media excitement the topic is once more buried in silence by, as it seems, a process of collective self-denial. The latest example is from spring 2008, when the historian Osmo Hyytiä published his new book "Helmi Suomen maakuntien joukossa - Suomalainen ItäKarjala 1941-1944" (The Pearl of Finnish Provinces - Finnish Eastern Karelia 1941-1944). Hyytiä very systematically describes the Finnish administration of Eastern Karelia during the occupation period, including the concentration camps.

The book "Suur-Suomen kahdet kasvot" (The Double Faces of the Greater Finland), which was published by the historian Antti Laine in 1982, was the first study that initiated a debate about the Karelian camps. He was himself very careful to point out that there are no parallels or similarities between the German concentration camps during the war and the Finnish methods to isolate the Russians in Eastern Karelia. A big concentration and labor camp was opened in Äänislinna (Petrozavodsk; today Petroskoi) in October 1941. The highest number of inhabitants in the camps was reached during spring 1942, when up to 24000 persons lived in different camps around Petrozavodsk. Laine estimated that the number of inmates made up 27 per cent of the total population in the occupied territories (Laine 2002; Lindholm 2005). 
Following the public debate, it seems to be easy to associate the term "concentration camp" with the Nazi annihilation camps, although the Finnish concentration camps in Eastern Karelia had totally other functions. For political or military reasons a part of the Russian population was regarded a security risk for the occupying power. The Finnish military authorities in Eastern Karelia needed to transfer a lot of people to other parts of the territory for different reasons: Some of them were a security risk, others just needed protection, and some were marked out for expulsion but needed a place to stay during the waiting time.

Because of diseases and famine the mortality was quite high in the camps as well as outside the camps, but in general the camps were not places of executions and systematic torture. Still, the selection for the camps was based on nationality and ideological criteria, so from the selection perspective the Karelian camps could be compared with the German concentration camps. Irrespective of similarities or differences with the Nazi-German camps, the existence of Finnish concentration camps in Eastern Karelia has always been politically sensitive.

In public debate the existence of the concentration camps in Eastern Karelia has often been related to the cooperation between Finland and Nazi Germany. The animosity against a deeper discussion about the Holocaust is not only caused by the debate about the camps. When Hyytiä, in his book, pointed out that the military commander-in-chief, Marshal Mannerheim, established the camps on a direct order, the debate focused even more on how the legendary national hero was treated in relation to the concentration camps. Critical comments - not always based on facts - maintaining that Mannerheim's co-operation with Hitler and his employment of "Nazi methods" was more of an ideological than of a pragmatic nature, met with a strong reaction from the nationalist camp in defense of the Marshal. ${ }^{5}$

This nationally quite sensitive issue, indicating that there was a strong relation between the Finnish concentration camps and Nazi ideology, definitely reduced the chances for an open debate about the Holocaust in Finland. There was an obvious risk that some could draw the conclusion that Finland was involved in the structures of the Holocaust which seems to have generated silence as well as a focus on the more heroic aspects of the war.

5 The debate on the website of the popular scientific journal Tiede, www.tiede.fi, gives illustrative examples. 


\section{Conclusions}

History is in daily use all the time, and for different purposes. Some aspects of history are used very actively - for example for political or ideological purposes. Some other aspects of history are used more seldom or are actually denied - also for political or ideological reasons.

The lack of discussion concerning various chapters in the Finnish World War II history is best understood when interpreted in light of political or ideological reasons. Particularly important reasons are, as argued in this article, the co-operation with Nazi Germany, the extradition of Jews, the establishment of concentration camps under the territorial expansion during the Continuation War 1941-1944, and not the least, the massacres and mass graves from the Civil War 1918. These are all aspects of a past where the Finns have been victims, perpetrators, collaborators and heroes. The uses of national history in relation to a past that has been closely tied up to international events might create an existential void in the Finnish memory culture. As Karlsson makes clear in this volume, individuals have a need to arrange their histories "in order to uphold or intensify feelings of orientation, anchorage and identity in a society". Especially traumatic events need to be integrated into larger, common narratives. Such a void could create uneasiness both in the political institutions and estrangement amongst Finns from their established past.

The unwillingness to debate Finland's role in relation to the Holocaust, has also had consequences for the didactics of history, especially when it comes to education in schools and the content of the curricula. As already mentioned, the Swedish-speaking schools readily imported didactical and practical working methods from Sweden and Norway, while there has been more genuine passivity in the Finnish-speaking schools, although with some exceptions. The national history of patriotism and courage has overlooked - and continues to overlook - the more painful aspects of history of Finland. To all this should be added the complex political situation of Finland during the postwar period until the dissolution of the Soviet Union. Bearing the position in the shadow of the Bolshevik Kremlin in mind, it is quite obvious why the discussion of the Holocaust and the relation to Nazi Germany was not at the top of the political agenda. The fate of Finland was to change from having close relations to Nazi Germany to being part of the sphere of interest of the Soviet Union, and with the strong influence of Moscow it was not appropriate to raise the question of concentration camps and executions. This might be quite understandable when discussing such a young na- 
tion state as Finland; especially taking into consideration how young the nation state of Finland was in 1939-1945.

\section{References}

Arnstad, Henrik (2009): Skyldig till skuld - en europeisk resa i Nazitysklands skugga, Nordstedts, Stockholm.

Bruchfeldt, Stéphane/Levine, Paul A. (1998): ... Om detta må ni berätta... En bok om Förintelsen i Europa 1933-1945, Regeringskansliet, Levande Historia, Stockholm.

Bruchfeldt, Stéphane/Levine, Paul A (2001): ... Kertokaa siitä lapsillenne. Kirja juutalaisten joukkotuhosta Euroopassa 1933-1945, with a national supplement by Jukka Hartikainen, Opetushallitus, Helsinki, pp. 52-69.

Forss, Stefan (2006): "Finland och fortsättningskriget”. In: Kungliga Krigsvetenskapsakademiens handlingar och tidskrift (6/2006), pp. 71-79.

Gerner, Kristian/Karlsson, Klas-Göran (2005): Folkmordens historia. Perspektiv på det moderna samhällets skuggsida, Atlantis, Stockholm.

Hansén, Sven-Erik (2004): “The Swedish 'People's School' in Finland and the Language Question: Homogenization and Differentiation". In: Journal of Curriculum Studies 36, no.6 (2004), pp. 645-655.

Hyytiä, Osmo (2008): Helmi Suomen maakuntien joukossa. Suomalainen Itä-Karjala 1941-1944, Edita Helsinki.

Karlsson, Klas-Göran/Zander, Ulf (eds.) (2006): The Holocaust on Postwar Battlefields, Sekel, Helsinki.

Karlsson, Klas-Göran (2008): Med folkmord i fokus. Förintelsens plats i den europeiska historiekulturen, Forum för levande historia, Stockholm.

Laine, Antti (1982): Suur-Suomen kahdet kasvot. Itä-Karjalan siviiliväestön asema suomalaisessa miehityshallinnossa 1941-1944, Otava, Helsinki.

Levy, Daniel/Natan Sznaider (2006): The Holocaust and Memory in the Global Age, Temple University Press, Philadelphia.

Lindholm, Sture (2005): Röd galenskap - vit terror. Det förträngda kriget i Västnyland, Söderströms \& Proclio, Helsingfors.

Rosenbaum, Alan S (ed.) (2001): Is the Holocaust Unique? Perspectives on Comparative Genocide, Westview Press, Oxford.

Sana, Elina (2003): Luovetut. Suomen ihmisluovutukset Gestapolle, WSOY, Helsinki. 
Silvennoinen, Oula (2008). Salaiset Aseveljet. Suomen ja Saksan turvallisuuspoliisiyhteistyö 1933-1944, Otava, Helsinki.

Sjöholm, Kaj (2004): "Swedish, Finnish, English? Finland's Swedes in a changing world”. In: Journal of Curriculum Studies 36, no. 6 (2004): pp. 637-644.

Suominen, Elina (Sana) (1979): Kuoleman laiva S/S Hohenhörn, WSOY, Porvoo.

Vihavainen, Timo (1991): Kansakunta rähmällään: suomettumisen lyhyt historia, Otava, Helsinki. 


\section{The Nazi Camps in the Norwegian Historical Culture}

JON REITAN

"When you look at these hammocks in three layers $[. .$.$] when it has become a museum here$ $[\ldots]$ it really does not say much. Because the inmates are not here, the stench is not here [...]. In the night prisoners went out of the barrack and touched the electric fence, they could not take anymore. And in the morning dead prisoners were hanging on these fences [...]. These are things we experienced and which cannot be visualized by looking at these hammocks."

Holocaust survivor, Robert Savosnick, Auschwitz, November 1992.

\section{A Holocaust survivor revisiting Auschwitz}

In the fall of 1992, 50 years after the deportation from Norway, the 77 year old pediatrician returned to Auschwitz for the first time since the end of World War II. His second meeting with the former concentration camp was taped by a journalist. The tape is today located in the archives of the Jewish Museum in Trondheim.

Robert Savosnick returned to a camp landscape which at the time was in the limelight of intense international attention (Van Pelt/Dwork 1996). A few months later, parallel to Steven Spielberg's world wide

1 The Jewish Community of Trondheim 1992. 
box office success "Schindler's list", a group of experts gathered to discuss the future of Auschwitz as a cultural memory, museum and site of learning (Marrus 1999). In spite of varying professional views on best practices for the preservation of the world's largest cemetery and memorial site, there was, and still exists, a broad consensus that the material presence of such disturbing remains benefits international society (Schofield/Johnson/Beck 2000).

A significant manifestation of this consensus is the fact that Auschwitz, as the only remnant of the Nazi camp system, is placed on the UNESCO World Heritage List. In its "Statement of significance", the communicative power of these material remains is highlighted as follows:

"At the centre of a huge landscape of human exploitation and suffering, the remains of the two camps of Auschwitz I and Auschwitz II-Birkenau, as well as its Protective Zone were placed on the World Heritage List as evidence of this inhumane, cruel and methodical effort to deny human dignity to groups considered inferior, leading to their systematic murder. The camps are a vivid testimony to the murderous nature of the anti-Semitic and racist Nazi policy that brought about the annihilation of more than 1.2 million people in the crematoria, $90 \%$ of whom were Jews." (Unesco 2009)

Remains of camp barracks and buildings, crematoria, watch-towers and barbed wire fences tend to function as material evidence of the Nazi policies of mass murder. However, concrete localizations of the past also bear several inherent dilemmas and challenges. Perhaps it was the risk of intellectual simplifications Savosnick had in mind, when he exclaimed outside one of the barracks in Auschwitz I: "When it has become a museum here, it really does not say much." His statement can be interpreted as a reflection over the possibilities and limitations both of the physical site, of architecture and language. As such, Savosnick positioned himself in the centre of a discourse which artists, authors, film directors, academics and others have been grappling with ever since Theodor Adorno's famous dictum on writing poetry after Auschwitz (Adorno 1969; Friedländer 1992; Levi/Rothberg 2003).

The taped revisit to Auschwitz almost 20 years ago illuminates several historio-cultural aspects of the Holocaust. On the one hand, we can understand his, the witness', thoughts as a message of concern: What have we really learnt, or what is there possibly to learn, from the Holocaust? Perhaps he also alluded to the problems of inscribing Auschwitz into our present understanding of reality? Regardless of what kinds of, and how many, cultural and didactical representations we make about 
the Holocaust, the past itself is irrevocably gone - "the prisoners are missing, the stench is missing". In my opinion, the dialogue between Robert Savosnick and a fellow traveler in the ruins of Auschwitz constitutes a small image of a complex interplay between private and collective memories, between consumption and production of history, between past realities and representations of the same. It is this interplay which the following text will discuss, empirically based on some of the former Nazi camp complexes established on Norwegian soil during WWII. ${ }^{2}$

\section{The afterlife of the prison camps in Norway}

The postwar European memorial sites which rose from the ruins of the Nazi camp system have been formative for the present iconographic status of the Holocaust in the Western World (Levy/Schneider 2002: 87). Particularly in the last few years, parallel to the inevitable passing away of the survivors, these landscapes have become increasingly important as evidence of truth of the Nazi mass crimes (Engelhardt 2002: 18). In Germany alone there are over 100 so-called Gedenkstätten in remaining physical environments from the concentration camps - with Sachsenhausen, Dachau, Neuengamme, Buchenwald and Bergen Belsen among the most well-known. Equivalent sites constitute significant cultural symbols in other countries as well, such as Terezin in the Czech Republic, Froeslevlejren in Denmark, Westerbork in the Netherlands or Mauthausen in Austria (Lutz 2009). ${ }^{3}$ And in the indisputable centre of this characteristic European landscape we find Auschwitz, which attracts more than one million visitors a year. The museum and the memorial site symbolize not only a place name and the main scene of the implementation of the Holocaust. Auschwitz has also become a concept for absolute evil, close to incomparable with other genocides and crimes

2 Nazi Germany established close to 500 prison camps in Norway between 1940-45. A total number of 150000 people were incarcerated in these facilities during the war. Among these, there were around 44000 Norwegian political prisoners, of whom 8500 were deported to concentration camps on the continent. Furthermore, 100000 Soviet Prisoners of War (POWs), 4200 Yugoslavian POWs and 1600 Polish POWs were deported to Norway from 1941 onwards. About 15000 East European POWs died in socalled Stalags, numerous satellite camps and work battalions in Norway either by execution or as a consequence of systematic maltreatment, exhaustion, starvation and disease. These numbers exceeded the total Norwegian military and civilian loss of lives during WWII. See Soleim 2005.

3 Analyses of such landscapes can be found in Bodemann 1998; Marcuse 2001; Young 1993. 
against humanity - a phenomenon which sociologist Ronit Lentin has labeled the Auschwitz code (Karlsson 2005; Lentin 1992).

The majority of the Jews who were deported to Auschwitz from all corners of Europe had already prior to the transports experienced suffering and death in camps and ghettos in their home countries. Most of the deported Norwegian Jews in the fall of 1942 and winter of 1943 were incarcerated either in Berg prison camp outside of Tönsberg, Sydspissen prison camp near Tromsö, Bredtvedt prison and Grini prison camp in Oslo, or the SS camp Falstad outside of Trondheim. ${ }^{4}$

It was on the remnants of the latter camp complex where the Norwegian Minister of Foreign Affairs, Mr. Jonas Gahr Støre, inaugurated the Falstad Centre in October 2006. This institution is today a statesponsored study centre for the history of imprisonment during WWII and modern human rights issues. The Centre, located in the former main building of the SS Lager Falstad, offers its visitors exhibitions, educational programs, research facilities, a library, seminar rooms and full accommodation. ${ }^{5}$ During the official opening of the centre, the foreign minister reflected on the dynamic functions of cultural buildings, and that it remains in our power to change their meaning and content:

"Buildings, monuments and symbols are established through choice and action. It is also in our power to change or expand the meanings and contents of these symbols: to become monuments, memorials, sites of experience, narratives, communication and education. This is what is now happening to Falstad. We are doing something with the site, which is now to become a national study centre for the history of WWII imprisonment and human rights. Many years of hard work have come - not to an end - but to a new beginning." (Støre 2006)

I understand this statement as a call to avoid memorial sites being depicted as static expressions of a definite, collective memory. These reflections are also shared by the linguist James Young. In his book The Texture of Memory he calls for memorial sites where material, political and esthetical factors merge and contribute to dialogue and active social commitment (Young 1993: x). It is within this image we must position the landscape and the institution Falstad, which lately has been subject

4772 Norwegian Jews were deported during WW II. Only 34 survived. Altogether 230 families were annihilated. See Justis- og politidepartementet 1998.

5 On behalf of the Norwegian Government, the restoration works were undertaken by the owner of the building, The Directorate of Public Construction and Property, in the years 2004-06. More here: www.falstadsenteret. no. 
to several public and even heated debates. The controversies around Falstad have had both historical, conceptual overtones - for instance with regard to what epochs of the site's history to include in the research and educational activities of the centre - but also material, like the shaping of the memorial in the Falstad Forest and the renovation of existing building structures at Falstad. ${ }^{6}$

In a broader postwar perspective, however, these remains of the Nazi camp system established in Norway have existed only in the margins of the national historical culture. ${ }^{7}$ This phenomenon has a complex background. In the following I will highlight a few central lines of development.

\section{The historio-cultural exit of the camps}

In 1985 the author and famous Holocaust survivor Primo Levi wrote about the relationship between the presence of the camp facilities and the spirit of the times:

"If we had been asked as we were liberated: 'What do you want to do with these infected huts, these nightmare barbed wire fences, these multiple cesspits, these ovens, these gallows?' I think most of us would have said, 'Away with it all. Flatten it, raze it to the ground, together with Nazism and everything that is German." (Levi 2005: 82)

To a certain extent, this appeared to be a real scenario in parts of Norway during the peace summer of 1945. Particularly hit by this mental condition were the camps for East European prisoners-of-war in Northern Norway, where the density of camps was superior to other regions of the country. Tearing down watch-towers, barbed wire fences and burning camp barracks might be interpreted as collective acts of symbolism,

6 Falstad has since the 1920s functioned as a special school for delinquent boys, as an SS Camp during the War Years 1941-45, as an internment camp for Norwegian Nazis and war criminals, from 1950 onwards yet again as a special school for so-called mentally disabled pupils, and finally as a museum and memorial site. One of the Falstad debates was the empirical focus of the PhD dissertation by Sem 2009.

7 This fact does by no means indicate an overall weak Norwegian tradition of WWII remembrance. On the contrary, no other period in our history has given rise to a corresponding amount of memorials and monuments. These can be found everywhere in the public sphere, and they have been inaugurated with great momentum in postwar Norway. See Eriksen 1995. 
maybe also as a continuation of the war - this time against the raw materiality of the Nazi past.

These concrete, physical actions to remove camp remnants from the North-Norwegian cultural landscape were soon followed by the harsh realities of the Cold War. With the repatriation of 80000 Soviet POWs from Norway, and an increasing suspiciousness of Russian espionage, this narrative of suffering and mass death was rapidly positioned in the shadowlands of the Norwegian historical culture. One of the major manifestations of the Cold War politics was the so called Operation Asfalt, a state-directed operation where the remains of dead Soviet POWs in the northern counties Nordland, Troms and Finnmark were dug up, collected in large sacks of asphalt and transported to the war cemetery Tjøtta on the Helgeland Coast (Soleim 2005). This action was described by the Soviet government as an "insult to the memory of Soviet soldiers", and it caused significant diplomatic turbulence between Norway and the Soviet Union. Only after the dissolution of the Soviet state did the climate of memory politics improve.

Instrumental to the public disinterest in this catastrophe, is probably furthermore the fact that 360 Norwegians, among them many returned Waffen-SS soldiers from the Eastern Front, served as guards in German POW camps. Some of these camps had extreme death rates among the prisoner population. A former Yugoslavian POW recalls in his memoirs:

"These Hird guards [the political soldiers of the Norwegian Nazi Party, Nasjonal Samling, authors note] were more dangerous than the SS guards. They beat and tormented us; they shot us like sparrows, in the work commandos and on the way there." (Reitan 2007)

The public marginalization of this catastrophic experience represents one, among several, instances of a lack of elasticity in the Norwegian historical culture. However, there is reason to believe that new research and other historical products about the Norwegian Waffen-SS volunteers will contribute to new ways of interpreting, representing and using WWII. ${ }^{8}$

With regard to another camp category in Norway, the so called Polizeihäftlingslager, where mainly political prisoners were incarcerated, it is to some extent surprising that these landscapes have occupied a modest position in the Norwegian historical culture. The sites in many ways reflected the catastrophic and painful consequences of resistance

8 The Holocaust Centre in Oslo is also conducting a research project on the Norwegian SS Volunteers, which will be finalised in 2010. Other recent publications on this issue are Christie 2008 and Veum 2009. 
and fierce fight against the Nazi system of terror - in other words, the nucleus of the Norwegian Gründungsmythos. The Polizeihäftlingslager perfectly projected an unambiguous moral, dichotomical system of "good" (prisoners from the Norwegian Resistance Movement) and "evil" (the brutal German SS camp regimes). From this angle, there is a strange disparity between, for instance, the history of Grini on the one hand, the largest prison camp in Norway with a population of close to 20000 prisoners, a war experience which has produced many memoir books, and on the other hand the afterlife of the camp landscape Grini. ${ }^{9}$ The material memory of the prison camp is today mediated through two monuments, the last one inaugurated by the HM Crown Prince Harald in 1990, and a low-budget, and non-professional museum exhibition, located in the former Abteilung Vermittlung of the camp. The Grini Museum was opened on May $8^{\text {th }} 1997 . .^{10}$

One possible explanation for this can relate to the 93000 Norwegians investigated under suspicion of treason. To meet the extensive demands for space during the up-coming war trials, 200 prison camps were established - many of them on the remains of abandoned Nazi installations (Nilssen 2008). Several of the largest camp complexes during the war were transformed into permanent internment camps for Norwegian Nazis and sympathizers - such as Grini, Falstad, Espeland near Bergen, Krøkebærsletta in Tromsdalen and Berg near Tønsberg.

In the summer of 1945, pragmatic spatial arguments and solutions seemed to merge into symbolic ones. Newspapers were on the one hand filled with articles on the lack of space within the Norwegian prison administration. In the local newspaper Vestfold Arbeiderblad we can read about camp Berg on May $24^{\text {th }}$ 1945: "The police are still arresting the traitors. But there is a need for space for the arrested. The police are therefore now working on expanding the prisons. At Berg there are now 400 men, but they intend to incarcerate 100 more in there" (Bugge 2001: 197). On the other hand, there was an obvious symbolism in placing Nazis behind the same barbed wire fences where "good" Norwegians had suffered during the war. And the most central camp complexes were renamed, to signal new meanings and avoid any possible linkage and comparison between the political prisoners, the "men of honor" imprisoned in these sites 1940-45, and the "quislings" populating the same

9 Among the most famous books about Grini are those by Lange/Schreiner 1946-7 and Nansen 1946.

10 The museum does not have a web page. Information of the museum and opening hours, Sundays 12-15, can be found on the web pages of the local authorities, Bærum Kommune, www.baerum.kommune.no. 
physical environments after the war. As such, Grini, Falstad and Berg were renamed into Ilebu, Innherad and Sem prison camps respectively.

In relation to the symbolic and real processes of transformations during the summer of 1945, I have found no references to the tragic imprisonment of the Jews prior to the deportations to Auschwitz. A number of emotional articles about the new names and functions of the camp facilities alluded to "the strong, national resistance movement", not to the Nazi mass murder of Jews and East European POWs. And it is former political prisoners and resistance fighters who express themselves, in particular through the interest groups "Griniklubben", "Falstadkomiteen" or "Norsk Samband av Politiske Fanger" - later to be renamed "Foreningen av politiske fanger". It was also the latter which first initiated the establishment of the Grini Museum. Many war veteran organizations closed down their activities during the Anniversary of Liberation in 2005. Until now, there is regrettably no substantial research on the vast archives which the veterans left behind, and on the positions and functions of these actors in the Norwegian historical culture.

Within this specific context it seems easy to draw parallels from the early afterlife of the camps to other categories of historical products from the same period of time. Significant features in the formatting of the public uses of the war past can, for instance, be found in the three volume work "Norges krig", published in the years 1947-1950. In an analysis of this book, historian Synne Corell writes that it is loaded with linguistic and harmonic references to a Norwegian fellowship community (Corell 2007). According to Corell, several groups of people are placed outside of a "we-category". Norwegian Jews are practically excluded from the overall narrative, while members of the Norwegian Nazi Party are labeled as social or moral dregs of society. Furthermore, the East European tragedy unfolding on Norwegian soil from 1941 onwards is hardly mentioned by the authors. ${ }^{11}$

In a national, consolidating process of reconstruction, there was no room for the two prisoner categories in Norway that fell victims to the Nazi genocidal policy. None of them could be integrated into a morally edifying image of resistance fighters and heroes, a feature which historian Ole Kristian Grimnes in 1990 called the "national syndrome of consensus" (Grimnes 1990). According to Grimnes, the Norwegian wartime experience served as a marker of a positive, national formation of identity throughout the postwar years. This essential feature seems to merge with the findings of historian Pieter Lagrou in The Legacy of Nazi Oc-

11 Corresponding patterns of inclusion - exclusion can be found in school textbooks. See for instance Skarsem 2007. 
cupation, where he demonstrates surprisingly many points of resemblance regarding how western countries constructed a national epos after WWII. Within the establishment of so-called patriotic cultures of remembrance there simply was no place for the Jewish catastrophe, because this narrative was not usable in producing edifying meaning (Lagrou 2000: 2).

In addition to this, there is a perspective of cultural memories, or perhaps - rather a lack of it. Archive research has so far proven that relevant Norwegian authorities after the war remained indifferent to these camp landscapes as cultural memories or future environments of learning. ${ }^{12}$ In an extensive archive of the Ministry of Justice and the Police, which managed the former camp facilities in the early postwar period, a letter from the director of Ilebu prison camp to the Ministry, dated September $3^{\text {rd }} 1948$, might serve to illustrate the status of the camp landscapes after the war:

"The watch-towers surrounding the inner camp area at Ilebu, built by the Germans, are - except from the towers in each corner - not in use. The towers that are placed between these corner towers obstruct the view, which makes it difficult to monitor. For this reason we suggest to tear down the towers, and possibly reuse the materials here at Ilebu."13

This letter also illustrates a postwar climate where the country was hit by a general lack of commodities. At times, this deficit was so precarious that barrack buildings in partly good shape were dismantled and used for other purposes. This happened repeatedly both at Falstad and Grini. For instance, a letter from a shoe factory in Halden to the postwar camp administration at Ilebu says: "We know from the daily press that dismantled barracks from Ilebu are put up for sale. We need barracks for working houses; there is a glaring shortage of rooms for workers in our company." 14

Around 1950, the majority of the internment camps for Norwegian Nazis were closed down, only to be given new functions - as public school institutions (Falstad), regular prisons (Grini) or community homes (Berg, today, in 2010, a so-called open prison). As such, the ma-

12 This subject will be elaborated more in my ongoing $\mathrm{PhD}$ dissertation, Norske bilder av tilintetgjørelsen. Holocaust og historiekultur, Norwegian University of Science and Technology, Trondheim. The project will be published in 2011.

13 Riksarkivet. Fengselsstyrets landssvikavdeling, D II, Da - Sakarkiv, sak 21, eske Da 0065 "Ilebu". Letter dated 03.09.1948.

14 Riksarkivet. Fengselsstyrets landssvikavdeling, D II, Da - Sakarkiv, sak 21, eske Da 0065 "Ilebu". Letter dated 15.12.1948. 
jor camp sites progressively were taken out of their historical, World War context. These many-faceted layers of different and changing meanings deposited in the camps' history of effects arguably corrupted the potentials of these sites as stable, moral, didactical and political points of identification. In particular, it seems that there were, for several years, difficult growing conditions for memorial arenas in landscapes overcrowded with the losers and traitors of the war. It is probably in the combination of these factors where we can find the answers to why the prison camps soon were consigned to the dark shadows of the national historical culture - in contrast to other history products from the same time, like books and memoirs, TV series, films and unambiguous monuments commemorating the heroes of the war, as elaborated by Zander in this volume.

\section{The return of the camp landscapes}

Elsewhere in Europe there are examples of preservation of camp installations from the late 1940s. Most often education and democratization formed an ideological and moral back curtain to cultural memory projects of this kind. However, several have born fruit only since the 1970 s (Marcuse 2001). In Norway, these historio-cultural movements took place at a much later stage. How can we explain that the former Nazi installations have again engaged the Norwegian public interest? And in what kind of narratives are these sites molded today, over 60 years after their disappearance from the public eye?

The decade between 1990 and 2000 represented in general a paradigm with regard to the level of public consciousness around former Nazi institutions in the country. Several new centers, like the Centre for Studies of the Holocaust and Religious Minorities in Oslo, the Nordsjøfartmuseet in Telavåg, Falstadsenteret, Nord-Norsk Fredssenter in Narvik and Stiftelsen Arkivet in Kristiansand were founded with some form of state support in this period. Research, remembrance and education constitute core institutional practices. ${ }^{15}$ In spite of variations regarding historical background and institutional profiling, all of them communicate the following main educational target: The wartime experience is to be used as a tool for stimulating the fight against racism and intolerance, and for human rights, democratization and humanitarian commitment. In other words, nurturing and safeguarding the memory of

15 The North Norwegian Peace Center in Narvik 1990, The Espeland Prison Camp Foundation in Bergen 2000, Falstad Memorial and Human Rights Centre 2000, The Archive Foundation in Kristiansand 2001. 
WWII is quite simply not enough to legitimize their public function, existence and state sponsoring. For instance, the Archive Foundation in Kristiansand, located in the former Gestapo headquarters in the city, is promoting itself as a centre for "history communication and peacebuilding", Falstad is a "memorial site and human rights center", while the North Norwegian Peace Centre in Narvik, localized in close proximity to the former death camp Beisfjord, profiles a bilateral focus on "peace" and "war memorialization". 16 This mindset, imprinted in all new memorial site concepts in Norway, seems to attract increasing attention from the state educational sector. As such, they might to some extent appear like competing elements to the older institution Foundation White Buses to Auschwitz, which in the past two decades has sent around 130000 school pupils to Auschwitz-Birkenau. Accompanied by former concentration camp inmates, the articulated target of these travels is for the students to learn, existentially and morally, from the experiences of the Holocaust. ${ }^{17}$

There are numerous other examples to illuminate this phenomenon of practical-political uses of history in Norway today. When the foreign minister spoke at the opening of the Falstad Centre in October 2006, his speech contained several temporal shifts and references from the extreme realities of the Nazi camps and the SS camp at Falstad, to contemporary issues of treatment of prisoners, international binding conventions and the human rights profile of the Norwegian Government:

"Everyone imprisoned at Falstad, and everyone today incarcerated at Guantanamo Bay in Cuba, in the Abu Ghraib prison in Iraq, or other places, and in all places not carrying recognisable names: They have the right to humanitarian treatment, and to be protected against injustice, torture, and against degrading and inhumane actions and punishment." (Støre 2006)

In the National State Budget for 2009, the respective memorial institutions were organized in a separate Chapter, Chap. 255 "Grants to Peaceand Human Rights Centres". A corresponding use of history is clearly mirrored also here, when the so called KUF committee in the National Parliament (Church, Education and Research) noted that preservation and access to the past is an important task to "avoid a repetition of history":

"The committee notes that in order to understand phenomena in our own time, such as denouncing, actualized for instance in Burma lately, it would be useful

16 More here: www.fred.no and here: www.stiftelsen-arkivet.no.

17 www.hvitebusser.no 
if topics like 'denouncement' were included in the presentation of World War II. Furthermore, the committee notes that this could be arranged for instance at the Falstad Memorial and Human Rights Centre.” (KUF 2008)

Furthermore, the introduction of this chapter outlines in particular the relationship between the material evidence of the past and the fact that in a short time there will be no survivors left:

"The KUF committee requested in the Budget Proposition S nr. 12 (2007-08) a case depicting the different perspectives of the varying memorial sites, and discussing the challenges of a time when we no longer have the witnesses among us. The Ministry has asked Vox [an agency of the Norwegian Ministry of Education and Research, my remark] to discuss with the Peace and Human Rights centers how to meet the National Parliament's call in relation to the time witnesses." (The Ministry of Education and Research 2008)

Evidently, the new memorial sites seem - at least to some extent - to inherit a role as "new witnesses" in an ongoing generational paradigm shift. This development is arguably an expression of collective wishes, and not least needs, to stabilize the memory of the Holocaust and the Second World War in otherwise changeable times. This "Era of the Witness", as this epoch is labeled by historian Annette Wieviorka (2006), has left several imprints in Norway. ${ }^{18}$ When the editor of the national newspaper Aftenposten in 2007 wrote that "we [...] are in the middle of a paradigm shift - without quite realizing the consequences of it", he was referring to the witnesses from WWII and the fact that they soon will be gone. ${ }^{19}$ A kind of powerlessness and anxiety reflected on the surface of the text: What awaits the collective "us" when there are no witnesses left?

In the fall of 2008, the Falstad Memorial and Human Rights Centre conducted geophysical investigations in the original camp area, targeting to uncover barrack foundations and other "things" originating from the SS camp. On September $29^{\text {th }} 2008$, director of the centre, Tone Jörstad, was interviewed in the biggest newspaper in Norway, Verdens Gang. Under the headline "Researchers intend to document Nazi traces", she was quoted as saying: "The traces and remnants of evil must be secured, the existence of the camps must be documented and we need to establish

18 For instance, the bestselling book, Tidsvitner - fortellinger fra Auschwitz og Sachsenhausen, was selected as "the most important book of the year" by the readers of the newspaper Morgenbladet in 2006: Jakob Lothe and Anette Storeide, ed., Tidsvitner - fortellinger fra Auschwitz og Sachsenhausen, Oslo: Gyldendal, 2006.

19 Aftenposten, 20.10.2007. 
a plan of preservation which must be integrated into the National Cultural Heritage Act." (Verdens Gang 2008) The examinations at Falstad continued in August 2009, including works to uncover unidentified mass graves in the former execution site - the Falstad Forest. Furthermore, 2010 marks the beginning of a plan to establish a new site of learning and contemplation in the old camp area surrounding the main building at Falstad. It remains to be seen how this project is conceptualized. Anyhow, in light of already ongoing processes it seems as if contemporary archaeology will constitute a major element in the forthcoming Falstad memorial landscape.

A smaller, but still similar, cultural heritage project is under development at the Grini Museum in Oslo. In the 1950s, one of the original barracks from the camp was replaced as a storage building in the municipality of Bærum. Today, local politicians have committed themselves to returning the barrack to its original surroundings in the Grini landscape. The aim of the project is to exhibit objects made by former Grini inmates in the barrack, in order to integrate the building into the existing exhibition concept. A local politician gave the following statement on the matter:

"It is important to speed up the process, so that we can finally return the Grini barrack to its original surroundings close to the museum. The war veterans are passing away, and therefore it is even more important to preserve history when those who carry it with them are gone. The Grini Museum constantly receives donations from families of Grini ex-prisoners. It would be a shame if we were to lose the opportunity to preserve the historical memorial site Grini and the personal memories from the former inmates." (Senterpartiet 2007)

In the contemporary Berg landscape, from where 227 Norwegian Jews were deported to Auschwitz during the war, only the former kitchen barrack, a few prison cells and barrack foundations are all that remain from the authentic camp landscape. In cooperation with Berg prison, the Vestfold Fylkesmuseum in Tönsberg wishes to develop an exhibition concept on the history of the camp in situ, mainly based on original "things" and objects found in and around the remnants of the camp. According to the project leader this exhibition will open in $2010 .^{20}$ The main target of the project is to "put Berg on the map", thus making manifest the ambition to convey lessons about the Nazi past and to push the history of the site and the Norwegian Holocaust towards the centre of our collective memory (Tønsberg Blad 2008).

20 Conversation with Curator Rune Sørlie, Vestfold Fylkesmuseum, Tönsberg, April 2009. 
A consensus-like highlighting of the cultural, moral and educational qualities of the material presence of the past seems to be a central indicator of our historio-cultural climate today. The historian Ewa Domanska speaks about a renewed, human "enchantment with things" and a "longing for reality". Things, or objects, appear as crucial in the making and legitimating of human identities, and as such function as active agents of social life: "The renewed interest in things signals a rejection of constructivism and textualism and the longing for what is 'real', where 'regaining' the object is conceived as a means for re-establishing contact with reality." (Domanska 2006: 337-348) There is an obvious correlation between the advanced, general position of existential matters of life and death, good and evil in our cultural sphere, and the establishing of memorial sites related to catastrophic experiences, such as natural disasters, wars, terror and genocide. Identifying the modern age with extreme tragedies and occurrences is described by sociologist Kai Erickson as "one of the social and psychological signatures of our time" (Erickson 1994: 240).

There is, however, some sort of paradox, or antagonism, in the close to obsessive attitudes towards the value of specific, authentic "things" on the one hand, like archaeological findings of barrack foundations, and the general historio-cultural pattern of universalizing and globalizing the wartime history on the other. In describing the genocide of European Jewry as a representation of an emerging "transnational political morality" and a "meta-narrative for suffering", historian Helmut Dubiel argues that the Holocaust has constituted a new practice of "a culture of apology" by leading Western politicians (Dubiel 2003). In this particular context it is interesting to register that the genocide has been incorporated into the narratives of the new Norwegian memorial sites, even in cases where historical lines of connection to the Holocaust are rather remote. This condition is manifested not least through rituals of commemoration, where the international Holocaust Day of Remembrance, on each January $27^{\text {th }}$, nowadays attracts far more medial attention than the traditional dates of April $9^{\text {th }}$ and Day of Liberation, May $8^{\text {th }}$.

The gradual incorporation of the Holocaust in the profiling of the new Norwegian memorial institutions can obviously be seen in light of international historio-cultural movements. Many argue that there has been a so-called reversal of remembrance in the last decades, where the Holocaust has taken over the functions of conventionalized victim roles and narratives of resistance (Alexander 2002). The historian Christoph Cornelissen writes that the Holocaust in the $21^{\text {st }}$ Century "einen Drehund Angelpunkt für die Formierung öffentlicher Erinnerungskulturen in Europa und Nordamerika abgegeben hat" (Cornelissen 2003). Daniel 
Levy and Natan Sznaider describes the genocide as a container for a cosmopolitan or universal practice of commemoration (Levy/Sznaider 2001), while historian Dan Diner seven years ago anticipated an establishment of a common European canon of remembrance in the image of the Holocaust: "The tendencies presently dominant indicates, that this will happen against the backdrop of the memory of the Holocaust as the constituting, in effect the inaugural event of a commonly shared European memory." (Diner 2003: 42)

Regarding national, historio-cultural energies, the restitutions at the end of the 1990s were undoubtedly among the most momentous. It all started with the article "Det norske jøderanet" ["The hold-up against the Norwegian Jews"], published in the newspaper Dagens Næringsliv by journalist Bjørn Westlie, on May $27^{\text {th }} 1995$. The article, dealing with the economic liquidations of Jewish property by the Quisling regime, was printed in a context which usually tends to preserve national master narratives. The unconventional perspective of Westlie therefore reached the media limelight, both on a national and international scale. Combined with pressure from abroad, the article activated a movement with a considerable effect on the position of the Holocaust in the Norwegian historical culture.

On June $26^{\text {th }} 1998$, three years after the article was published, the National Parliament Proposition nr. 82 was accepted in a Cabinet Meeting after recommendations by the Ministry of Justice and Police. The contents of the Proposition, named "Et historisk og moralsk oppgjør med behandlingen $i$ Norge av den фkonomiske likvidasjon av den jødiske minoritet under den 2. verdenskrig”, referred to a preceding work published as a White Paper called "Inndragning av jødisk eiendom i Norge under den 2. verdenskrig". ${ }^{21}$ The historical and moral restitution had both an individual and a collective part. The first constituted a sum of money paid out to former victims of anti-Jewish actions as a token of acknowledgment, the latter, collective part, was divided into three separate sections: a one-time allocation with the main target of preserving Jewish culture in future Norway, another amount going to Jewish cultural actions abroad, and finally the financing of a national research center, today known as the Centre for Studies of the Holocaust and Religious Minorities (HL-senteret), localized in the former villa of Vidkun Quisling.

21 Justis- og politidepartementet 1998, and Norges Offentlige Utredninger 1997. The background chapter in the Proposition refers explicitly to the public attention caused by Bjørn Westlie's article in Dagens Næringsliv. 


\section{Conclusion}

In the book Echoes of the Holocaust, historian Klas-Göran Karlsson writes that the Swedish Government Project "The Living History Forum" was a success with impact on several international levels. The establishment and the actions of this institution put Sweden on the world map, and deserve to be called a paradigm shift in the Swedish historical culture (Karlsson/Zander 2003: 15ff). The Norwegian restitution, and its history of effects, obtained a corresponding effect in Norway. In a time where several international movements of compensation (Karlsson 2008: 58) were under way, Norway was the first country to conclude a process with such an economic and moral scope. This fact was dramatically underscored when the country in 2003 became a full member of the institution Task Force for International Cooperation on Holocaust Education, Remembrance and Research (ITF). In 2009 Norway occupied the Chairmanship of the ITF.

In 2007, in Prague, all member states of the ITF adopted a so-called "Historic site Resolution", highlighting the importance of identifying, marking and preserving sites of destruction - be they camp landscapes, ghettos or execution sites during the Holocaust - for posterity. The examples from Grini, Berg, Falstad and finally the ITF, illustrate clearly the reinforced national and international history-cultural positions of memorial sites. Our present "enchantment with things", the globalization and universalization of the Holocaust together form solid political, social and cultural foundations to the once forgotten camp landscapes and environments. Still, it seems rather striking that along this main current of positive attitudes towards these disturbing remains of the past, there has hardly existed any counter flow, at least not in public Norway. For instance, there is little Norwegian research analyzing effects of school pupils visiting memorial sites from WWII. Do teaching and excursions to Falstad, Grini or Berg strengthen the democratic, tolerant and humanitarian stock of 15 year old pupils? Will travelling with the Foundation White Buses to Auschwitz immunize youth against xenophobia? By mirroring the experiences of the Holocaust in modern narratives on topics such as informing or contemporary policies towards refugees, is there an inherent risk to assess the past ahistorically, and furthermore perhaps contribute to the establishing of black and white images of the world of yesterday and today? Can such juxtapositions of the past and present inflict upon us a blindness of perspectives in any way? A comprehensive research project "The Role of commemoration sites, original sites and historical museums in Holocaust Education and Human Rights Education in the EU', conducted by the Living History Forum with vast 
international expertise on board, was published in January $2010 .^{22}$ Hopefully this project, illuminating questions and subjects as presented above, can stimulate future Norwegian research within this field of expertise.

According to historian Tony Kushner, it is precisely the abstracted, universal aspect of the Holocaust which in the past few decades has made the Holocaust so usable in the liberal world of imagination - centered on values like pluralism, tolerance and diversity (Kushner 1994: $272 \mathrm{ff}$ ). In regard to future perceptions, negotiations and uses of past Nazi relics, I think the former camp landscapes will occupy even more prominent positions and functions than is the case today. It is probably the combination of these factors which stimulated Foreign Minister Jonas Gahr Støre when he addressed former camp inmates, their children and grandchildren at the opening of the Falstad Memorial in 2006: "Buildings, monuments and symbols are established through choice and action. It is also in our power to change or expand the meanings and contents of these symbols [...]. Many years of hard work have come not to an end - but to a new beginning."

\section{References}

Adorno, Theodor (1969): Prismen. Kulturkritik und Gesellschaft, Frankfurt am Main.

Alexander, Jeffrey C. (2002): "On the Social Construction of Moral Universals. The Holocaust from War Crime to Trauma Drama". In: European Journal of Social Theory, Volume 5, No. 1, 2002, pp 5-85.

Bodemann, Y. Michael (1998): "Eclipse of Memory: German Representations of Auschwitz in the Early Postwar Period". In: New German Critique, No. 75, 1998, pp. 75-89.

Bugge, Svein (2001): Skyggene fra Quislings hønsegård. Den norske konsentrasjonsleiren på Berg i Vestfold, Færder Forlag, Larvik.

Corell, Synne (2007): "Hva er historien om krigen? Historiografien om den tyske okkupasjonen av Norge under annen verdenskrig". In: Fortid, 2/2007, pp16-21.

Cornelissen, Christoph (2003): "Was heisst Erinnerungskultur? BegriffMethoden-Perspektiven”. In: Geschichte in Wissenschaft und Unterricht (54), 10/2003, pp. 548-563.

22 Fundamental Rights Agency homepage: www.fra.europa.eu. 
Christie, Nils (2008): "Serberleirene i Nord-Norge. Gjensyn med en studie av fangevokterne". In: Bernt Hagtvet (ed.),Folkemordenes svarte bok, Universitetsforlaget, Oslo, pp 461-468.

Diner, Dan (2003): "Restitution and Memory: The Holocaust in European Political Cultures”. In: New German Critique, no. 90, Taboo, Trauma, Holocaust, 2003, pp. 36-44.

Domanska, Ewa (2006): "The Material presence of the past". In: History and Theory 45/2006, pp. 337-348.

Dubiel Helmut (2003): "The Remembrance of the Holocaust as a Catalyst for a Transnational Ethic?”. In: New German Critique, No. 90, Taboo, Trauma, Holocaust, 2003, pp. 59-70.

Engelhardt, Isabelle (2002): A Topography of Memory. Representations of the Holocaust at Dachau and Buchenwald in Comparison with Auschwitz, Yad Vashem and Washington DC, P.I.E. Peter Lang, Brüssel.

Erickson Kai (1994): A New Species of Trouble: Explorations in Disaster, Trauma and Community, Norton, New York.

Eriksen Anne (1995): Det var noe annet under krigen, Pax Forlag, Oslo.

Friedländer Saul (ed.) (1992): Probing the Limits of Representation. Nazism and the 'Final Solution', Harvard University Press, Cambridge, Massachussetts, London, England.

Grimnes, Ole Kristian (1990): "Historieskrivingen om okkupasjonen. Det nasjonale konsensussyndromets gjennomslagskraft”. In: Nytt Norsk Tidsskrift, 2/1990, pp. 108-121

Hoffmann, Detlef, (ed.) (1998): Das Gedächtnis der Dinge. KZ-Relikte und KZ-Denkmäler 1945-1995, Frankfurt.

Justis- og politidepartementet (1998): Stortingsproposisjon nr. 82 (199798), Et historisk og moralsk oppgjør med behandlingen i Norge av den $\varnothing$ konomiske likvidasjon av den jødiske minoritet under den 2. verdenskrig, Oslo.

Karlsson, Klas-Göran (2008): Med folkmord i fokus - Förintelsens plats i den europeiska historiekulturen, Forum för Levande Historie, Skriftserie 6: 2008, Stockholm, http://www.levandehistoria.se/ files/skriftserie_6_web.pdf.

Karlsson, Klas-Göran (2005): "Förintelsen som historiekulturellt fenomen - en översikt". In: Historisk Tidskrift, 4/05, pp.721-733.

Karlsson, Klas-Göran/Zander, Ulf (eds.) (2003): Echoes of the Holocaust. Historical Cultures in contemporary Europe, Nordic Academic Press, Lund.

KUF [The Standing Committee on Education, Research and Church Affairs] (2008): Innstilling fra kirke-, utdannings- og forskningskomiteen om bevilgninger på statsbudsjettet for 2009, kapitler un- 
der Kunnskapsdepartementet og Kultur- og kirkedepartementet, samt forskningskapitler under Nærings- og handelsdepartementet, Fiskeriog kystdepartementet og Landbruks- og matdepartementet (rammeområde 16), http://www.stortinget.no/no/Saker-ogpublikasjoner/Publikasjoner/Innstillinger/Budsjett/2008-2009/ innb-200809-012/?lvl=0

Kushner, Tony (1994): The Holocaust and the Liberal Imagination, Blackwell, Oxford.

Lagrou, Pieter (2000): The Legacy of Nazi Occupation. Patriotic Memory and National Recovery in Western Europe, 1945-65, Cambridge University Press, Cambridge.

Lange, August/Schreiner, Johan (eds.) (1946-47): Griniboken, Volume 1 and 2, Gyldendal, Oslo.

Lentin Ronit (1992): Postmemory, received history and the return of the Auschwitz code, http://www.eurozine.com/articles/2002-09-06lentin-en.html.

Levi, Neil/Rothberg, Michael (eds.) (2003): The Holocaust: Theoretical Readings, Edinburgh University Press, Edinburgh.

Levi, Primo (1985): The Black Hole of Auschwitz, Polity Press, Cambridge.

Levy, Daniel/Sznaider, Nathan (2001): Erinnerung im globalen Zeitalter: Der Holocaust, Suhrkamp, Frankfurt am Main.

Lothe, Jakob/ Storeide, Anette (eds.) (2006): Tidsvitner - fortellinger fra Auschwitz og Sachsenhausen, Gyldendal, Oslo.

Lutz, Thomas (2009): Dear Internet Visitor! Welcome to the memorial museums database, http://www.memorial-museums.net/WebObjects $/ \mathrm{ITF}$

Marcuse, Harold (2001): Legacies of Dachau. The Uses and Abuses of a Concentration Camp 1933-2001, Cambridge University Press, Cambridge.

Marrus, Michael (1999): "The future of Auschwitz: A case for the ruins". In: Peter Hayes (ed.), Lessons and Legacies, Vol. III, Memory, Memorialization, and Denial, Northwestern University Press, Evanston, Illinois, pp 169-177.

Nansen, Odd (1946): Fra dag til dag, Oslo, Dreyer.

Nilssen, Trond Risto/Reitan, Jon (2008): Falstad - nazileir og landssvikfengsel, Tapir Akademisk Forlag, Trondheim.

Norges Offentlige Utredninger (1997): NOU-rapport 1997:22. Inndragning av jødisk eiendom i Norge under den 2. verdenskrig.

Reitan, Jon (2007): Ansikt til Ansikt, Script, permanent museum exhibition of the Falstad Centre, Levanger. 
Schofield, A. J./Johnson, William Gray/Beck, Colleen M. (eds.) (2000): Matériel Culture. The archaeology of twentieth century conflict, Routledge, London and New York.

Sem, Leiv (2009): For oss var Falstad det norske Holocaust, University of Oslo.

Senterpartiet (2007): Få Grinibrakka til Grinimuseet nå!, http://www. senterpartiet.no/article47206.html?articleID=47206

Skarsem, Bjørn (2007): Andre verdenskrig i lærebøker for gymnaset/den videregående skolen, MA History dissertation, Norwegian University of Science and Technology, Trondheim.

Soleim, Marianne N. (2005): Sovjetiske krigsfanger i Norge 1941-45 antall, organisering og repatriering, Doctoral thesis in History, University of Troms $\varnothing$.

Steiner, Georg (1969): Language and Silence, Harmondsworth, Penguin Books.

Støre, Jonas Gahr (2006): Offisiell åpning av Falstadsenteret (Norwegian only): http://falstadsenteret.no/støre_tale_senteret_071006. htm

The Jewish Community of Trondheim (1992): Tape, marked "Robert Savosnick, 1992". Interviewer unknown.

Tønsberg Blad (2008): “Graver i Tønsbergs nazi-historie”, 14.07.2008.

Unesco (2009): Auschwitz Birkenau. German Nazi Concentration and Extermination Camp (1940-1945), http://whc.unesco.org/en/list/31

van Pelt, Robert Jan/Dwork, Deborah (1996): Auschwitz: 1270 to the Present, Yale University Press, New Haven, Connecticut.

Verdens Gang (2008): Forskere vil dokumentere nazi-spor, 22.09.2008, http://www.vg.no/nyheter/innenriks/artikkel.php?artid=516775

Veum, Eirik (2009): De som falt: nordmenn som døde i tysk krigstjeneste, NRK Aktivum, Oslo.

Wieviorka, Annette (2006): The Era of the Witness, Cornell University Press, Ithaca and London.

Young, James (1993): The Texture of Memory. Holocaust Memorials and Meaning, Yale University Press, New Haven and London. 


\title{
The Norwegian Fascist Monument at Stiklestad 1944-45
}

\author{
TOR EINAR FAGERLAND AND TROND RISTO NILSSEN
}

In 1944, the Norwegian national socialist party, Nasjonal Samling (NS), erected a large monument at the historically and symbolically important place of Stiklestad in central Norway. A few days after the May 1945 liberation, the monument was demolished and removed by the Norwegian resistance movement, with the exception of a nine meter tall obelisk, which was too big to be removed. The obelisk was instead torn down and buried at the site.

Raised by Norwegian ultra-nationalists, and not by the German occupants, the monument represents a difficult and ambiguous part of Norwegian war history that does not agree well with clear-cut distinctions between the German aggressor on the one side, and a united Norwegian opposition on the other. Since 2006, attempts have been underway to uncover remains of the monument. ${ }^{1}$ The idea is to make a partial excavation of the buried obelisk, and to produce a study exhibition at the site, focusing on uses and abuses of the past, problematic features of nationalism and the handling of difficult aspects of the past in contemporary Norway. After giving an introduction to the historical site of Stiklestad, this paper first discusses the NS-monument in the light of international literature on historical places, monuments and countermonuments. It then turns to the didactic challenges and potential of the buried monument, discussing how a painful and ambiguous past might become a tool for reflection and dialogue.

1 The authors of this paper are both members of a task group established by the board at Stiklestad National Culture Centre in 2006. See Raaen 2007. 


\section{Stiklestad: A place of history - a place of memory}

For almost one thousand years, Stiklestad has remained Norway's most important historical place. Stiklestad is important for both political and religious reasons and plays an important part in the Norwegian collective memory on a local, regional and national level. ${ }^{2}$ Its fame dates back to 1030 , when Stiklestad was the scene of a great battle where the Christian king Olav II Haraldsson (1015-1030) was killed by his opponents. Shortly after the battle, rumours of the dead king's healing power started to circulate. Defeat was turned into victory as the dead king was sanctified. ${ }^{3}$ After the battle, Olav was moved to Nidaros, and miracle stories connected to St. Olav soon turned Nidaros into an important destination for pilgrims. ${ }^{4}$ The legacy of St. Olav also made Nidaros and central Norway a natural choice for the new archbishop's seat in Norway in 1153. In addition, "ruling on behalf of St. Olav - the eternal king of Norway" became an important part of the political legitimacy of all later medieval kings in Norway (Krag 2003: 117). The battle of Stiklestad in 1030 thereby marks the breakthrough of both Christianity and a unified national kingdom in Norway.

In the nationalist era of the late $19^{\text {th }}$ and early $20^{\text {th }}$ century, Stiklestad became a popular venue for national gatherings. In 1930, 40000 people attended the 900-year anniversary of the battle in 1030. The NS, whose establishment in 1933 was inspired by the NSDAP's ascent to power in Germany, chose to gather at Stiklestad already in 1934. At St. Olav's Day on 29 July 1944, the party celebrated the 10th anniversary of its presence at the site.

Today, an annually recurring expression of the place's symbolic value is found in the play "The Saint Olav drama", staged at Scandinavia's largest open air theatre. The play, which was first performed in 1954, attracts an annual number of 20000 spectators and is the result of exten-

2 The use of the term "collective memory" has been criticized for its vagueness. The critics have, however, not yet been able to introduce a more satisfactory analytical tool for understanding the social dimension of memory. And as the British historian Bill Niven points out: "Its very vagueness, perhaps, is the source not just to our dissatisfaction with it, but also of its appeal" (Niven 2008: 427-436).

3 The cult connected to the dead king spread out throughout Scandinavia and Northern Europe. In England he soon became the most popular saint, and the worship of St. Olav has left traces all over the British Isles, the oldest one dating back to the 1160s. See Krag 2003:116

4 Nidaros is the historical name of today's city of Trondheim. Norway's third largest city, Trondheim is located ninety kilometres south of Stiklestad. 
sive cooperation between professionals from across the country and local amateurs and volunteers (Kvistad 2003).

Picture 1: Stiklestad 1930. At the 900-years anniversary of the battle of Stiklestad approximately 40000 people gathered at the site.

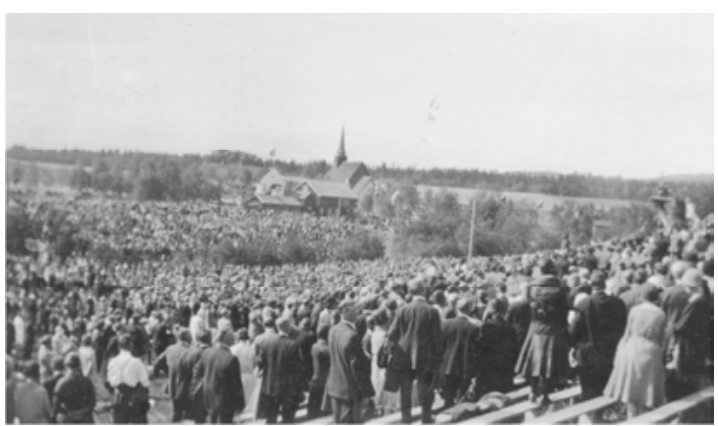

Photo credit: Alf Dahling, Stiklestad Nasjonale Kultursenter, Norway.

\section{NS and Stiklestad}

The NS came to power in 1940, with the help of the German occupants. The party was based partly on a national socialist ideology, partly on a radical version of traditional national values (Sørensen 1989: 27-70). While in power, it worked energetically to promote its own interpretation of traditional Norwegian values and symbols. In order to legitimize its collaboration with the German occupants and the attempt to convert Norway into a national socialist society, NS made extensive use of oldNorse history (Sørensen 1998: 27-46). 
Picture 2: Vidkun Quisling unveils the monument in 1944.

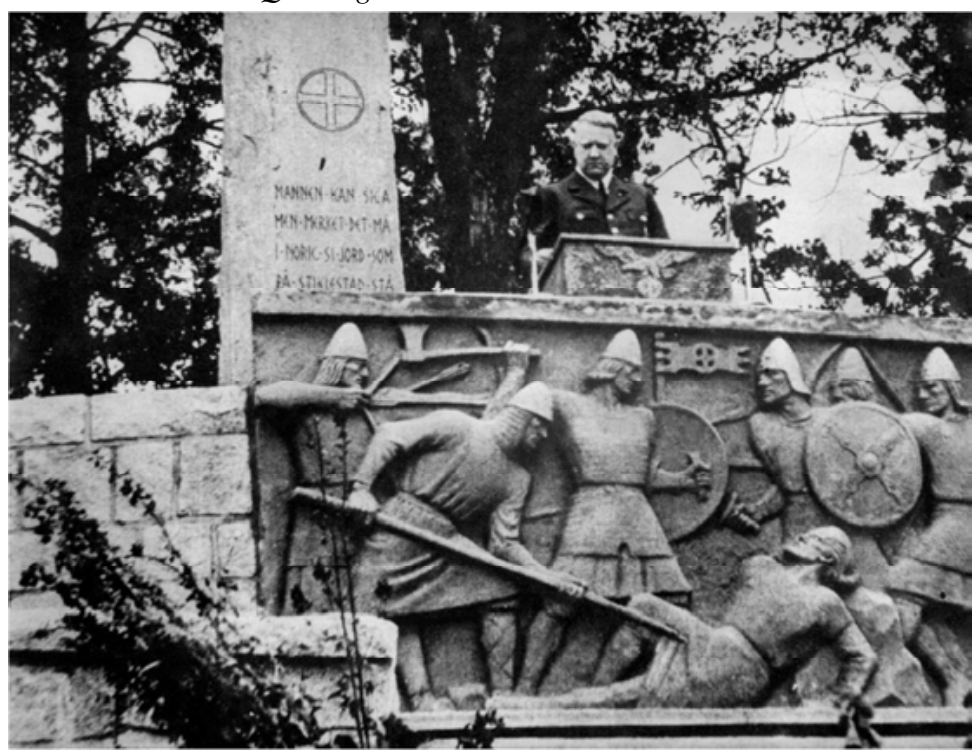

Photo credit: Unknown, Stiklestad Nasjonale Kultursenter, Norway.

By means of the monument at Stiklestad the party aimed to establish a spiritual and ideological link between the medieval king and patron saint, King Olav Haraldsson, and the party leader, Vidkun Quisling (Mehle 1944: 211). The monument was created by the famous sculptor and NS-member Wilhelm Rasmussen, and in contrast to previous and later installations at Stiklestad, the NS-monument was huge and dominating. It consisted of a large flight of steps, a relief displaying the battle at Stiklestad in 1030 and the death of King Olav, and a nine meter tall obelisk displaying the sun wheel - the NS' symbol, often worn by the storm troopers and party members as armlets and pins. Engraved in the obelisk were some lines from the poem "Tord Foleson" by the Norwegian writer Per Sivle. ${ }^{5}$

5 Tord Foleson was King Olav's standard-bearer at the battle of Stiklestad. According to the myth, Foleson lost his life in the battle, but only after having managed to plant the king's banner in the ground, where it would remain throughout the battle. The Poem was written in 1885 , in a period when Norway was in union with Sweden, but when Norwegian nationalism was dawning. Its most famous line reads as follows: "The symbol stands, even when man falls".

The poem is also quoted in a Memorial Wall at the former concentration camp Bergen-Belsen commemorating the Norwegian prisoners there, thus showing how traditional nationalist symbols could be used for promoting very different ideas and messages. 
In Norwegian tradition, World War II is portrayed as a period dominated by national unity (Eriksen 1995: 42-94). Approximately 55000 Norwegians were, however, members of the NS during the war. Norwegians thus had different opinions on the German occupation, and they responded to it in different ways. Since the large majority of the population disliked collaboration with the occupants, it was important for the leadership and the members of NS to show that their motives were just as morally untainted and nationally orientated as the ones of the noncollaborators. The use of traditional Norwegian symbols was an important part of the party's political communication. The building of the NS-monument at Stiklestad was meant to be interpreted as a way of presenting the party's core values, internally towards its own members, and externally towards the rest of the Norwegian population. ${ }^{6}$

The planning and building of the NS-monument at Stiklestad was not done by the Germans or in cooperation with the occupants. It was an entirely Norwegian project, demonstrating the will and ability of the NS to act independently on motives it regarded as pure and national. ${ }^{7}$ The timing of the project further underlines this independency, as the monument was raised at a point in time where German defeat was inevitable. The monument represents, in many ways, a blurring of the wellestablished boundaries between nationally orientated heroes on the one side, and traitors and footmen for the Germans on the other. This has made it a difficult part of the past to include in traditional ways of remembrance. The buried monument has thus remained a part of our unspoken past, both at a local and a national level.

\section{Stiklestad in the aftermath of the war}

A conference held at Stiklestad in 2005 sparked a debate about the future of the buried NS-obelisk in the media, among academics and in the local community. Representatives of the older generation, including both resistance veterans and former Norwegian SS-volunteers, oppose any kind of intervention at the site. Others, especially younger people, argue that the silence has lasted long enough, and that it is time to bring this

6 On the fascist way of political communication, see Griffin 1996.

7 Archival studies undertaken by the authors show that the regional NSleader, Torbjørn Eggen, was instrumental in the planning and implementation of the project. The project had the support of Vidkun Quisling and the party leadership in Oslo, but not of the German authorities who actually tried to stop the building. The party's own ideological arguments for the monument are presented in Mehle 1944. See also Fagerland 2010. 
part of Stiklestad's history to light. Some feel that an excavation of the monument would be tantamount to an acceptance or even glorification of the NS-regime. Others fear that the monument will be a popular gathering place for neo-Nazi groups. Finally, some also point to the monument's pedagogical potential. The question of what to do with the obelisk fuels emotional debates between different generations and different interest groups. The complex picture represents a huge challenge for the Stiklestad National Culture Centre (SNK), whose primary task is the dissemination of the St. Olav heritage.

\section{Places, monuments and counter-monuments}

The geographer Tim Creswell outlines "location", "locale" and "sense of place" as three fundamental aspects of the concept of place. "Location" refers to the fixed objective co-ordinates on the earth's surface. "Locale" refers to the material setting for social relations - the actual shape of place within which people conduct their lives. Finally, "sense of place" refers to the emotional attachment people have to place (Creswell 2004: 7). The concept of place therefore represents both fairly unchangeable structures made by nature (location), an interplay between human beings and nature marked by both continuity and change (locale), and an ongoing production of social meaning (sense of place). The two last elements in Creswell's definition clearly indicate that the concept "place" means more than just a neutral container, or physical framework, for human interaction. Our perceptions of identity and belonging are closely connected with places and the sense of meanings we read into them, and some places are therefore infused with more meaning and prestige than others (Creswell 2004: 50).

The meaning of a place is sometimes closely connected with important historical events. At historical places the place in itself represents both the relative continuity of the physical landscape and the continuous changes made by people and societies. At such places the changeability of time is counterbalanced by the constancy of the place and a sense of closeness to historical events can be experienced more distinctively (Eriksen 1999: 92). Historical places are therefore well suited and commonly used as theatres and meeting spots for presentation, interpretation and re-interpretation of the past for groups and communities (Rodell 2008: 15-30).

At historical places of special importance, the significance of the place is often emphasized by monuments (Eriksen 1999: 94-97). These monuments are reminders of historical events, but also of the current 
significance and relevance of these events (Stugu 2008: 91-96). Historical monuments have traditionally been unambiguous, and their main purpose has been to provide authoritative interpretations, to simplify, to clarify and to create unifying identities based on shared memories (Michalski 1998). Some of the essence of a group, a community or a nation is that the individuals that constitute these entities share a great many things, and that there are others that they have forgotten. One of the main functions of traditional commemorative artefacts is therefore that they permit only certain things to be remembered, and that they by exclusion cause others to be forgotten (Forty/Küchler 1999: 7-9).

Groups with different interpretations of the past will in general not erect competing monuments on the same historical site. Instead, each group will seek to remove the opponent's monument and replace it with its own. This happened during the German occupation when NS held the power at Stiklestad and in 1944 physically removed the Olav column from 1807 in favor of its own monument. It happened again in 1945, when the NS-monument was destroyed by the Norwegian resistance movement. It was important for the NS to erect their own monument at Stiklestad before St. Olav's Day in 1944, and it was equally important for the victors of the war to erase all traces of the NS-monument prior to St. Olav's Day in 1945. The NS-monument represented an ideology considered incompatible with the values of the Norwegian post-war society and shortly after the war the Olav column from 1807 was reerected. In this way Stiklestad was re-conquered as a site for national unity and identity.

An alternative to the traditional ways of remembrance presented above is the counter-monument (Gegen-Denkmal) philosophy. This philosophy was developed in Germany as an attempt to cope with the country's traumatic heritage from WWII (Michalski 1998: 172-189; Young 1993: 27-48). A central principle is the readiness to face painful and ambiguous memories. Self-criticism is also very important. This means courage and a will to face unpleasant topics, but also a willingness to question values which are highly regarded by individuals and society in the past and the present. According to James Young, the countermonument philosophy with its painful self-reflection is the most powerful expression of a new German generation which is conscious of its ethical duty to remember, but at the same time deeply sceptical towards traditional ways of remembrance.

In contrast to traditional history and monuments, the countermonument philosophy's goal is not to provide simplifying and unifying interpretations. Instead, the main goal is to spur debate and reflection about the past in itself, as well as about how today's society interprets 
and makes use of the past. A counter-monument is therefore interrogative rather than authoritative, critical instead of self-exalted, challenging instead of reassuring, dynamic instead of static and complex instead of one-dimensional.

\section{Stiklestad: A place with many layers of history}

Use of painful and problematic heritage in Western Europe is commonly related to different aspects regarding moral, ethical and political training (democratization). There are several ways of dealing with an inglorious past, and one of the most striking is how the former Nazi concentration camps are taking part in the democratization processes by transforming the traces of genocide and repression to sites of knowledge, learning and reflection. Wolfgang Benz points out that the former memorial sites must avoid being "cult-like places of emotions". Instead they should be starting points for moral and political reflections. Commemoration can be a key to engagement and reflections on essential features regarding specific painful events in the past, and must "calmly and assuredly" be permanent components in the political culture. That is why, according to Benz, the memorial sites should be an integral part in commemoration practices and political discourse, not solely in the public interest through anniversaries (Benz 2005:33).

For good or for worse, the different layers of history at Stiklestad represent case studies of how regimes and political movements try to define, adapt and grasp the political legitimacy of St. Olav for contemporary purposes. One of the questions that arose in dealing with the Nazimonument was whether the obelisk should be excavated at the place it was buried, exhibited inside the museum building or moved to a warrelated museum. Didactic uses of the past can take different directions, but in our context we strongly believe in taking advantage of the authenticity of the place. In order to link educational programs directly to the place and the physical remains still existing, we therefore wish to show the excavated remains of the monument in situ and to produce an indoor study exhibition, also at Stiklestad. 
Picture 3: The Fascist Monument at Stiklestad torn down, May 1945.

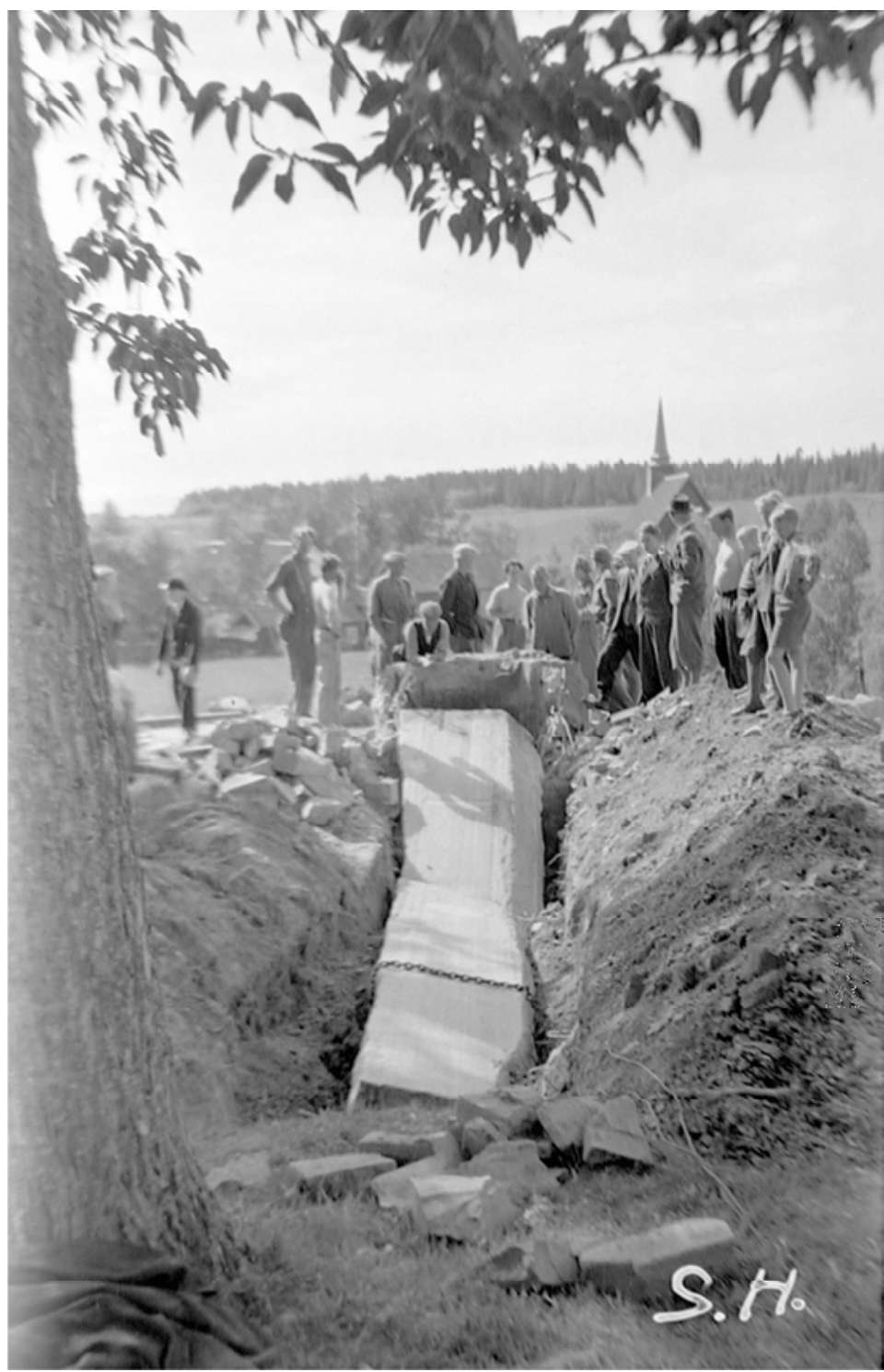

Photo credit: Sigurd Hegdahl, Foreningen Gamle Steinkjer

The theoretical foundation of both the excavation and the study exhibition is, at least partly, linked to the counter-monument perspectives presented earlier in this paper. In our attempt to make use of the authenticity of the place and our strong belief in including several different layers 
of history into the project, the SS-Dienststelle Neuengamme study exhibition and the outdoor exhibition at KZ-Gedenkstätte Neuengamme have been important sources of inspiration. The main task of KZ-Neuengamme is to present the history of the place as a part of the concentration camp system in the Nazi-period. However, the memorial is also an example of how West Germany dealt with historic places of the Nazi period in the post-war years. After a long-lasting conflict over its realization, the memorial, in its current shape, contains multiple layers of utilization before and after 1945. The memorial's topography thereby reflects the claims of different actors on local, national and international level. Neuengamme is presently in a process of restructuring on the basis of recent historical, pedagogical and creative insights. Remains from the concentration camp period, for instance the prison inside the concentrations camp, the former roll-call area and the prison latrine, have been excavated and are now parts of a landscape consisting of markers, symbolic reconstructions and wartime and postwar buildings. ${ }^{8}$

Both the counter-monument philosophy and the "new archaeology" approach used in Neuengamme, focus on the dialogical dynamic between the landscape, the visitors and new and old installations in use. The project at Stiklestad aims to release, and not to seal, the discussion. The planned combination of excavations, installations and exhibition aims to confront the society and stimulate the exchange of ideas and reflection between generations and in the general public at large. Hopefully, the inclusion of new layers of history will regenerate the significance of the place and increase its potential to communicate with a continuously changing society.

\section{A meeting place for dialogue and learning}

After the war, membership in Nasjonal Samling was defined as treason by Norwegian law, and all members were criminalized and sentenced (Dahl/Sørensen 2004). Disclosures about the concentration camps and other forms of Nazi cruelty added to the tension and the moral condemnation from the rest of the population (Lauridsen 2002; Westlie 2009). ${ }^{9}$ Elements of the "ice-front" between the two sides still exist, and "former NS-member" and "child of a NS-father or mother" remain stigmatized

8 (KZ-Gedenkstätte Neuengamme: http://www.kz-gedenkstaetteneuengamme.de/).

9 The atrocities committed by the infamous informer Henry Rinnan and his group probably made reconciliation in central Norway (Trøndelag) more difficult than in many other parts of the country. 
social categories. For 60 years there has been little dialogue between those who judged and those who were judged. As a result, many former NS-members and also many of their descendants have remained in small sub-cultures dominated by little self-reflection and even less selfcriticism. ${ }^{10}$ During the war, Stiklestad was used to legitimize a regime based on racism, dictatorship and indoctrination. After the war, the place has occasionally been used by extreme right wing organizations as well. One reason for the existence of such organizations might be that the well-established black and white interpretations of WWII have provided little room for dialogue and few meeting places for learning and reflection.

According to modern museum philosophy (often labeled as "new museology"), promoting dialogue about ethical dilemmas should be among the main tasks of museums today (Corsane 2005: 38-70). Still, as Young points out, there is an inverse proportion between the huge amount of memorialization of the past taking place, and the striking lack of contemplation and study invested into the same past (Young 1993: 273). The Vietnam Memorial Wall in Washington made by the young Chinese-American Maya Lin in 1982 is, however, an example of the potential for dialogue and contemplation that lies in including also the darker and more ambiguous parts of the past. Situated among the huge traditional monuments at Washington Mall, all celebrating former American presidents and generals, the wall is in many ways an inversion of its surroundings. According to May Lin, the aim of her design was to bring about the realization of loss and a cathartic healing process in the American people, and the monument has turned out to be a highly treasured place for the expression of grief. The monument is also in its essence interrogative, implying terrible questions about futility, dying in vain, and about when and for what Americans should die in war (Forty/Küchner 1999:137-142; Sturken 1997:44-84).

It is a widely held belief that the preservation of monuments, artefacts and other traces from the past enable us to remember the past, and that the decay or destruction of such traces implies forgetting. Some

10 Skepticism towards established knowledge about WWII and the Holocaust is still widespread among former NS-members. Such suppressions are also found among their descendants. On this topic, see for instance Olden 1988 and Westlie 2002. The work of the Danish historian John T. Lauridsen shows many parallels between the collective remembrance in Denmark and Norway. Also in Denmark, those who chose the wrong side during the war remained in their roles as villains. Lauridsen's work also shows that neither convictions nor the years after wars have contributed to an increased understanding of democracy among former Nazi-members and their descendants (Lauridsen 2002). 
traces from the past are therefore put on special protection lists, while others are left to decay or, like the NS-monument, are deliberately destroyed. The destruction of the NS-monument in 1945 is therefore a classical example of iconoclasm: the destruction of physical artefacts in hope of achieving oblivion. All destructions of monuments leave however, a void, and sometimes these voids can be just as noticeable as the monuments themselves (Forty/Küchner 1999:10). The strong emotions and sentiments revealed in the present debate imply that the physical removal of the monument did not lead to permanent oblivion of the dark past at Stiklestad.

The presence of the NS-monument and the national socialists' use of the St. Olav heritage represent a sidetrack to the positive heroic national narrative of Stiklestad. The buried obelisk and its invisible place in the Norwegian collective memory of WWII provides, however, important insight into the values and motives of NS-members as well as insight into post-war thinking about the NS and its members. The passage of time has only made the didactic potential of the buried obelisk more evident. And, as illustrated by the example of the Vietnam Memorial Wall at the Washington Mall, even at places already heavily infused with monuments and meaning is it possible to approach the past in new and more dialogical ways.

A pedagogical programme focusing on the dark history of Stiklestad could therefore highlight questions regarding both the past and the present. Who were the members? What were their motives? Could we have done the same under similar conditions? Why was Stiklestad important for the National Socialists? And finally, why has the "ice-front" between those on the right, and those on the wrong side, after 60 years, not been replaced by dialogue and learning? The "obelisk project" at Stiklestad thus has a potential to stimulate reflections, not only about the NSmonument itself, but also about nationalism, democracy and our own post-war history culture.

\section{References}

Benz, Wolfgang (2005): Places of Remembrance, Culture of Remembrance. Exhibition catalogue for The Dachau Concentration Camp, 1933 to 1945, Text and photo documents from the exhibition, with CD, KS-Gedenkstätte Dachau 2005, Karl M. Lipp Verlag, Munich.

Corsane, Gerard (ed.) (2005): Heritage, museums and galleries. An Introductory Reader, Routeledge, London. 
Cresswell, Tim (2004): Place; a short introduction, Blackwell Publishing, Oxford.

Eriksen, Anne (1995): Det var noe annet under krigen; 2.verdenskrig i norsk kollektivtradisjon, Pax, Oslo.

Eriksen, Anne (1999): Historie, minne og myte, Pax, Oslo.

Fagerland, Tor Einar (2010): NS-bautaen på Stiklestad, forthcoming.

Forty, Adrian/Küchler, Susanne (1999): The Art of Forgetting, Berg, Oxford.

Griffin, Roger (1996): "Staging the Nation's Rebirth: The Politcal and Aesthetics of Performance in the Context of Fascist Studies". In: Günter Berghaus (ed.), Fascism and Theatre; Comparative Studies on the Aesthetics and Politics of Performance in Europe, 1925-1945, Berghahn, Oxford, pp. 11-29.

Krag, Crag (2003): "Olav 2 Haraldsson den hellige". In: Norsk biografisk leksikon, volume 7, second edition, Oslo.

Kvistad, Ynge (ed.) (2003): Stiklestadspelet: Slaget som formet Norge, Oslo.

Lauridsen, John T. (2002): Dansk nazisme 1930-45 - og derefter, Gyldendal, København.

Mehle, Eyvind (1944): Olavstanken; Fra Stiklestad til Stiklestad, Centralforlaget, Oslo.

Michalski, Sergiusz (1998): Public Monuments: Art in Political Bondage 1870-1997, Reaktion Books, London.

Niven, Bill (2008): "On the use of 'Collective Memory"”. In: German History; The Journal of the German History Society, Volume 26, number 3, Oxford July 2008, pp. 427-436.

Olden, Asgeir (1988): Født skuldig, Oslo.

Raaen, Per Steinar (ed.) (2007): Makt og merke i tusen år; Forstudierapport, Stiklestad.

Stugu, Ola (2008): Historie i bruk, Samlaget, Oslo.

Sturken, Marita (1997): Tangled Memories. The Vietnam War, the AIDS Epedemic and the Politics of Remembering, University of California Press, Berkeley.

Sørensen, Øystein (1989): Hitler eller Quisling. Ideologiske brytninger i Nasjonal Samling 1940-1945, Cappelen, Oslo.

Sørensen, Hans Fredrik/Dahl, Øystein (eds.) (2004): Et Rettferdig oppgjør?: rettsoppgjøret i Norge etter 1945, Pax, Oslo.

Rodell, Magnus (2008): "Monumentet på gränsen; om den rumsliga vändningen och ett fredsmonument”. In: Scandia, årgang 2008, bind 74, hefte 2, pp. 15-52.

Westlie, Bjørn (2002): Oppgjør; I skyggen av Holocaust, Aschehoug, Oslo. 
Westlie, Bjørn (2009): Fars krig, Aschehoug, Oslo.

Young, James (1993): The Texture of Memory. Holocaust Memorials and Meaning, Yale University Press, New Haven. 


\title{
The Holocaust and Memory Culture: The Case of Sweden ${ }^{1}$
}

\author{
KRISTIAN GERNER
}

The Holocaust was not conceptualized as such in Sweden until the early 1980s. Until then, the main focus in both scholarly and public discussion of the Second World War was on the consequences for Sweden. The research project Sweden during the period of the Second World War, in Swedish "Sverige under andra världskriget", SUAV for short, dealt with the war primarily from political, diplomatic and military perspectives. In this project, which produced twenty $\mathrm{PhD}$ dissertations in history and two anthologies between 1971 and 1986, the Holocaust was not regarded as related to Swedish history (Ekman 1979; Ekman 1986). Also, when the project was placed in an international context in a conference in the House of Parliament in Stockholm in 1995, the issue of the Holocaust and Sweden was not approached (Ekman/Edling 1997). Only one of the dissertations in the SUAV project touched upon the issue: Hans Lindberg analyzed Swedish refugee policy in the period immediately before the Holocaust (Lindberg 1973).

Because known facts about Swedish complicity in Nazi German policies during the first war years were usually avoided in the historical studies, it is possible to argue that the Swedish example bears some resemblance to the historiography on the war in the first post-war decades in one of the belligerent states, France (Bosworth 1994). It seems that a vague sense of shame made historians play down the subjects of the Jewish policy of the Vichy regime and Sweden's refugee policy vis-àvis Jewish people (Ekman 2003; Heuman 2006).

1 I thank Klas-Göran Karlsson for valuable comments on the first draft of this article. 
In Sweden, the specific interest in the history of the Holocaust emerged from the memory turn in historical research, on the one hand, and from the impact of mass culture on historical science, on the other. The best known example of mass culture influencing the historical knowledge of the Holocaust was the American television series The Holocaust. It was broadcast in Sweden in 1979 under the title Förintelsen, which literally means "the annihilation." The term "Förintelsen" became the ubiquitous word for the Holocaust in Swedish. It came to be spelled with a capital " $F$ ". This is not according to the ordinary spelling rules in Swedish. In Swedish, the concept of "the Holocaust" acquired an extremely unique quality (Andersson 2002; Andersson 2003; Gerner \& Karlsson 2003).

The combination of the memory dimension in historical science and historical fiction in mass culture helped shape a context of morality issues concerning research subjects related to the Holocaust. This tilt towards moral issues becomes evident when one compares the previous Swedish historiography on Sweden during the Second World War with the following Swedish historiography on Sweden and its relation to the Holocaust. Although it is possible to discern both a moralist and a realist paradigm in public debate during the war and immediately after it, "the Holocaust as a matter that concerns Sweden" was briefly approached only once before the 1990s, namely in 1963 in the supplement volume of the new edition of Carl Grimberg's popular world history (Ekman 2003: 19).

\section{The national memory of the Holocaust}

The non-conceptualization of the Holocaust did not mean that the extermination of the Jewish people was a totally neglected issue in Swedish historiography. However, the focus was not on the fate of the Jews but rather on two Swedish personalities who became mythologized as rescuers of Jews, Raoul Wallenberg and Folke Bernadotte. Their actions concerned Jews in Budapest in 1944, and prisoners - some of whom happened to be Jews - in concentration camps in northern Germany in early 1945 , respectively. In the summer of 1944, the Swedish government allowed the US War Refugee Board to channel money through the Swedish businessman Raoul Wallenberg to enable the rescue of Jews in Budapest. The latter was given the status as a diplomat at the Swedish legation in Budapest and was able to rescue Jews by distributing Swedish passports to prospective victims and organizing their legal escape (Lajos 2004). In early 1945, the chairman of the Swedish Red Cross, 
Count Folke Bernadotte, made an agreement with the Nazi regime allowing him to bring Scandinavian prisoners and some others from Nazi concentration camps to Sweden in special buses, "the White Buses" (Persson 2002).

During the first decades after the war, Swedish society took pride in the reputation of having rescued Jewish people from the Nazis. In addition to Wallenberg's and Bernadotte's missions, the most famous action was the admission of more than 7000 Danish Jews who, aided by Danish fishermen and thanks to an early warning about imminent deportation to German concentration camps, managed to escape across the straits of Öresund in October 1943 (Kreth/Morgensen 1995). However, this action was not analyzed in Swedish historical science until it was discussed, in a comparative perspective, in a monograph by an American historian in 1987 and in a PhD dissertation from Stockholm University in 2006 (Byström 2006; Koblik 1988).

Both Wallenberg and Bernadotte became national heroes. Their tragic fates made these figures overshadow those whom they had saved. Wallenberg disappeared after having been arrested by Soviet troops in Debrecen in Hungary on 17 January 1945. Jewish terrorists assassinated Bernadotte in Jerusalem in September 1948 when he was there on a UN mission to solve the conflict between Israel and the Arabs of Palestine.

A dissertation on the Wallenberg mission, which Attila Lajos from Växjö University published in 2004, broke new ground in the sense that it focused on the events themselves on location in Budapest rather than on Wallenberg (Lajos 2004). Lajos was the first to use Hungarian language sources. Swedish colleagues criticized Lajos for unduly deheroizing Wallenberg (Liljegren 2004; Lundmark 2004; Wahlbäck 2004; Zander 2006). However, Lajos's most important result was that he was able to demonstrate that all previous Swedish research on Wallenberg had focused on the man and not on the Jewish people who he rescued. In this way, the impression of a rather belated Swedish scholarly interest in the Holocaust as such was reaffirmed.

In a similar way as Wallenberg's mission, Bernadotte's mission has also been re-evaluated. A historian from Gothenburg University, Ingrid Lomfors, has broken new ground by highlighting the fact that this mission was selective: Scandinavians were to be rescued first and others, including Jews, only if this was expedient. The facts about the manner in which the mission was carried out had been known already when it occurred. However, Lomfors argued that Bernadotte's mission primarily and consciously selected non-Jews (Lomfors 2005a; Lomfors 2005b). The political scientist Sune Persson, also from Gothenburg University 
contested Lomfors's conclusion. He maintained that Bernadotte did his utmost to rescue anyone within reach (Lomfors 2002; Persson 2003).

It is a fact that Bernadotte's mission rescued between five and six thousand Jewish people among a total of about 21000 prisoners. Some of these, many of whom were Polish women, were brought to southern Sweden, where Lund University is situated. In 1945, the University had a Polish lecturer, Zygmunt Lakocinski. In 1945, he served as an interpreter for the Polish speaking Jewish women who had been rescued from the Ravensbrück camp. He realized that the memories of the rescued women were worth preserving, not least because they could be used as testimonies in the expected trials of Nazi war criminals once the war had ended. Lakocinski saw to it that five hundred individuals of the rescued were interviewed and that their stories were recorded (Kulturhistoriska föreningen för södra Sverige 2004).

\section{The oral history of survivors}

At the time when the prisoners who had been rescued from the Nazi concentration camp of Ravensbrück arrived in Sweden, there was at Lund University a professor of history named Sture Bolin. He took a professional interest in the histories of the former concentration camp inmates. In 1944, Bolin had published the book The One-sided Violence, an analysis of Nazi propaganda and diplomacy on the eve of the Second World War (Bolin 1944). Bolin designed a research program dealing with the memories of the rescued concentration camp inmates and appointed Zygmunt Lakocinski as director of the research. From the professional point of view this was a pioneering project, because at the time nobody had cared to collect testimonies of Nazi camp survivors using systematic, scholarly methods of investigation: it was oral history avant le mot. Also in another respect Bolin's initiative was before its time. Interviews had certainly been used as source material for scholars, but mainly in ethnological studies. Now a highly skilled professional historian took an initiative that can be seen, in retrospect, as an early call for memory research. Sture Bolin apparently felt that something exceptional had occurred and that this called for extraordinary measures in order to document it.

Two Swedish government agencies, Statens Arbetsmarknadskommission (The State Labour Market Committee) and Statens utlänningskommission (The State Committee on Foreigners) financed the interview work. It was carried out by an enlightenment agency, The Swedish Institute of Foreign Affairs, which was established in 1938 with the aim 
of educating the Swedish public about international politics and which had close connections to the Swedish ministries of defense and of foreign affairs.

As was mentioned above, Lakocinski carried out 500 interviews. However, because the Swedish state ceased to sponsor the project, in November 1946 this work came to an end without the materials being published. In 1974 the archival materials were deposited in the University Library in Lund. In 1995, fifty years after the original documentation project, the archive was opened to research (Universitetsbiblioteket Lunds Universitet 2005). This became possible thanks to donations from a number of private Swedish and foreign foundations. ${ }^{2}$ Later, the Swedish state agency The Forum of Living History also gave financial support to the project.

However, only a year and a half after the end of the Second World War, the Swedish authorities lost interest in the memories of the survivors. The remembrances of the war among these new inhabitants in Sweden, many of whom later became Swedish citizens, were relegated to the dusty shelves of the University Library in Lund. Only thanks to the new interest in a new historical period, letters, annotations and artifacts made by the inmates of the Ravensbrück concentration camp during their imprisonment finally came to form a permanent exhibition at the ethnographic museum Kulturen (Culture) in Lund. (Nilsson Nylander 2004; Ravensbrück project 2005). The museum Kulturen had been founded in 1892. Its aim was to "save artifacts from the old peasant society that was about to disappear." Its founder, Georg J:son Karlin also included in the collections artifacts from all over the world. The idea was that in order to understand their own culture, Swedes must be given the opportunity to compare it with other cultures (Om Kulturen 2009). It is noteworthy that thanks to the comparative vision of its founder, memorabilia from the nadir of human culture, the Holocaust, became an exhibit in a Swedish museum of culture.

In 2005, the year after the permanent exhibition in Kulturen opened, a number of the interviews from 1945 with the survivors from Ravensbrück finally became available for the Swedish public. In his book "Voices that never fall silent", Artur Szulz presented Lakocinski and his work and published witness reports from Ravensbrück together with reports from Auschwitz, Buchenwald, Majdanek, Plaszow, Treblinka, Sachsenhausen, and Stutthof (Szulc 2005).

2 The sponsors were Eduard and Sophie Heckscher's Foundation, The Memorial Foundation for Jewish Culture, The Nordenstedt Foundation, The Conference on Jewish Material Claims Against Germany, Margit and Lennart Carlsson's Foundation and The Forum for Living History. 
It is evident that neither Swedish civil society nor the authorities had recognized a need to highlight the fate of the surviving victims from the Holocaust in spite of the fact that detailed information on their suffering was available already in 1945. The delay of fifty and almost sixty years until the opening of the archives and the exhibition, respectively, is an eloquent example of the Swedish policy and culture of silence concerning the fate of the victims of the Holocaust.

\section{Another memory - the Swedish self-examination}

In 1991, the journalist Maria-Pia Boëthius published a book which was highly critical of Swedish concessions to German demands during the war (Boëthius 1991). New research that was inspired by the debate caused by Boëthius's book placed these concessions in focus. Also, the rather authoritarian Swedish social policy came under scrutiny within the wider context of racism. The Swedish eugenics program which was initiated before the war and continued into the 1970s became the subject of both research and public debate (Tydén 2002; Zaremba 1999).

In the 1970 s and 1980 s, Sweden changed from being culturally rather homogenous into becoming a multicultural country. Successive waves of immigrants, mainly from other European countries, had been assimilated or at least very well integrated into Swedish society from the Middle Ages until the 1960s. The last such wave happened to be those secularized Polish Jews who left Poland in the wake of the antisemitic policies after the 1967 Israel-Arab states war and the student protests against Soviet interference in Polish cultural affairs in 1968. However, beginning in the 1970s, a large number of people arrived who remained less well integrated. They were imported labor and political refugees. Many came from Latin America and the Middle East. In the course of the 1980s and 1990s, there were manifestations of xenophobia and racism in Swedish society targeting the new categories of immigrants. This development clashed with official policy and it tainted the image of the morally good Sweden. Towards the end of the 1990s, the interest in the Holocaust became part of Swedish official policy exactly because the authorities felt a need to fight xenophobia and racism by way of educating about the Holocaust. It was presumed that widespread knowledge of the Holocaust would cure Swedish society from xenophobia and racism.

A news report in the Swedish radio became the triggering event for the official Swedish interest in the Holocaust. The news was that in June 1997 a research institute in Stockholm, CEIFO, published a survey which said that Swedish youth did not know much about the Holocaust. 
The Swedish premier Göran Persson was alarmed and took up the issue in the Parliament during its last session before the summer recess. The effect of Persson's initiative was a parliamentary resolution on the creation of an information agency. It was called Living history. Already in the autumn, the agency published its first book about the Holocaust, aimed at a broad public (Bruchfeldt/Levine 1997). In 2003, The Forum for Living History became a state institution (Karlsson 2003: 15-16). ${ }^{3}$

The campaigns of Living History created an increased interest also in research about Sweden's relation to different aspects of the Holocaust. Ten years after the inception of Living History, two substantial historical anthologies presented investigations of Sweden's relations with Nazi Germany and Swedish policy vis-à-vis Jewish refugees in the period 1920-1950 (Andersson/Kvist Geverts2008; Andersson/Tydén 2007). In his dissertation one of the contributors to the first volume, Mikael Byström, showed that there were attitudes and views among Swedish bureaucrats concerning Jewish people that implied that if Sweden had been under direct Nazi control, Jews in Sweden and especially the noncitizens among these people might have been treated in the same manner as the Vichy regime treated Jewish people (Byström 2006).

In another dissertation, Karin Kvist Geverts applied the concept of "antisemitic background noise" as an explanatory factor. The idea is that Swedish bureaucrats who were responsible for implementing refugee policies, although they were not consciously antisemitic, anyhow acted upon premises that said that Jews were a special people that Swedish society should be wary of receiving and therefore restrict immigration of (Kvist Geverts 2008b). Kvist Geverts argued that antisemitic ${ }^{4}$ background noise was normal in Sweden in the 1930s. Clerks could discharge open antisemitism at the same time as they gave expression to antisemitic ideas (Kvist Geverts 2008a). The implication is that Swedish society was imbued with a kind of subtle, seemingly harmless antisemitism, the consequences of which had deadly consequences for the targets, the Jewish refugees who were not accepted by Sweden.

3 The homepage is at www.levandehistoria.se

4 Since there is no such thing as "semitism", the term used in this text for hatred of Jews, antisemitism, is not hyphenated. CF Langmuir (1996: 16) 


\section{The Holocaust and communism in Swedish historical culture}

Among historians based at Lund University, the belated Swedish interest in Holocaust research took an international turn. In 2001, the research project "The Holocaust in European Historical Culture" was launched, with funding from the Tercentenary Foundation of the Bank of Sweden. By 2008, this project had produced three $\mathrm{PhD}$ dissertations, three anthologies and one monograph (Dietsch 2006; Gerner/ Karlsson 2005; Karlsson/Zander 2003; Karlsson/Zander 2006; Karlsson/Zander 2008; Sniegon 2008; Tossavainen 2006). The focus was not on historiography but on the manifestations of historical consciousness related to the Holocaust, in museums, films, novels, places of commemoration and monuments in a number of west European states - the Scandinavian countries, Germany, Great Britain, France and Italy - and Israel. The project also covered former communist countries - Croatia, Czechoslovakia (and the Czech and Slovak Republics), the GDR, Hungary, Poland, Romania, Russia and Ukraine. The Holocaust was treated together with investigations concerning the place in historical culture of the other experience of terror in these societies, Stalinism. The focus on historical culture and not on history per se produced the result that the two horrors of the Holocaust and of Stalinist repression were seen not only as complementary evils but also as competing for space in the historical culture of the excommunist states.

Members of the research project on the Holocaust in Lund taught about crimes against humanity in the Stalinist Soviet Union in education programs for school teachers and journalists that were arranged by The Forum for Living History. The idea was to invite reflections and discussions on the similarities and dissimilarities between the two totalitarian systems with respect to their policy of mass murder. Finally, ten years after its inception, The Forum for Living History launched an education program on the crimes against humanity committed by communist regimes. The Forum chose to put a special focus on Joseph Stalin's USSR, Mao's China and Pol Pot's Cambodia.

The influence of international historical studies on the place of the Holocaust and Communism in the historical culture of former Communist states in Europe, on the one hand, and on the other hand views among political groupings in Sweden - mainly but not exclusively connected to the Liberal Party - that Communist regimes had violated human rights to such a degree, resulted in the thesis that it was relevant to teach the Swedish public about these regimes as well. 
Very few historians and social scientists in Sweden have taken an interest in the study of Communist regimes. Placing Communism seemingly on an equal footing with Nazism was a new and shocking experience. Those Swedish academics who did not study Communist regimes thus experienced the new addition to the program of the Forum for Living History in Sweden as an expression of anti-Communism. More than five hundred Swedish academic historians and social scientists protested against the addition of the communist dimension of genocide by way of a public call for condemnation of the new program and, moreover, for the abolishment of The Forum for Living History as such (Historieuppropet 2008). The enlightenment project on Communist crimes thus released a roll call among Swedish intellectuals that would not accept any enlightenment project that included teaching about the crimes against humanity perpetrated by Communist regimes.

It is not a matter of people belonging to the Communist Party of Sweden in its nonagenarian guise as The Left Party, but rather of identification with the utopian gleaming goals of the communist ideology and cause. Although individuals had condemned the organization of Living History in 1997, no one had bothered to organize a public appeal against it. The abolishment appeal in 2008 ostentatiously aimed at the very idea of state-sponsored enlightenment projects. It is relevant to note that the chosen protest strategy invoked the idea of the night-watch state, an idea which is usually linked to liberal rather than socialist political ideology. It goes without saying that if this logic became the rule, rather many institutions in Swedish society would have to be dismantled, including different authorities that enlighten the public.

In this context, it is relevant to mention that a book on crimes against humanity under communist regimes, which was published at the time of the new project by The Forum for Living History, met high academic quality standards. The book, an overview of academic research in English, German, Russian, Chinese (Mandarin) and Swedish on the regimes of Stalinist Russia, Mao's China and Pol Pot's Cambodia, actually happened to throw a certain light on the protest. The appeal appeared to be directed not against a simplifying popularization but against an informative text that reflected the state of the art in communist studies. The authors of the book defined crimes against humanity as "murder, extermination, enslavement, deportation, and other inhumane acts committed against civilian populations, before or during the war; or persecution on political, racial or religious grounds" (Karlsson/Schoenhals 2008: 5). They applied this standard of judgment to their history of Stalin's, Mao's and Pol Pot's regimes. 


\section{Genocidal background noise}

The Holocaust has always been regarded with abhorrence by an overwhelming majority of Swedish intellectuals and as has been noted above, there was no organized protest movement against the activities of The Forum for Living History concerning teaching the history of the Holocaust. Whereas, in spite of the label "Living History", the Holocaust had been firmly anchored in the past, Communism really is living history. One of the parties in the Swedish parliament, although it calls itself simply "The Left Party", traces its ancestry back to the Swedish Communist Party. The Left Party celebrated its $90^{\text {th }}$ anniversary in 2007, i.e., on the anniversary of the party that had been founded in 1917 and which had been a member of the Communist International and thereafter had nurtured intimate contacts with and received financial support from the Communist Party of the Soviet Union (Björlin 2001).

The first relevant point is that the Swedish Left Party is a continuation party of and not a successor party to the Swedish Communist Party. The Swedish Left Party thus has inherited the historical legacy of the socalled "real existing socialism", including Stalinism. The objection that many individual members of the Left Party are decent people is another matter. It might well be that members of Fascist parties also are decent people. What is relevant here is the historical legacy of communism when it comes to the societal role of direct successor parties today, such as the Communist party in the contemporary Czech Republic and, what is relevant in the present context of Sweden, the Swedish Left Party which claims heritage from the Swedish Communist Party (from 1917), which was a member of the Comintern.

The second relevant point is exactly that, in contrast to Nazism, Communism is a living ideology in contemporary Sweden. The issue is whether it should be treated by Swedish state agencies - the education system, museums and the Forum on Living History - as equally menacing to society as Holocaust denial, antisemitism and racism.

"Crimes against humanity committed by Communist regimes" is a complex concept. In the Swedish context, the concept was coined as an antidote to the Holocaust rather than to "the crimes of Nazism". The argument was that the picture of the genocides of the twentieth century would be incomplete if Communist crimes were not treated in historiography and enlightenment work alongside the Holocaust. The framework of interpretation for the new project on Communist regimes was according to the basic tenet of Living history, i.e. that ideology is a necessary precondition for genocide. In a similar way as the Holocaust was, as it were, programmed in Nazi ideology, the Communist mass murders 
- conceptualized as genocide - were programmed in communist ideology under Stalin's, Mao's and Pol Pot's regimes, i.e. the three Communist regimes that the Forum selected as the focal points of the new project. This was the idea behind the new project.

Undoubtedly, the "crimes against humanity committed by Communist regimes" were placed upon the agenda of Living History because the Holocaust was there. One notes that the theory of totalitarianism is tacitly accepted as a framework. However, whereas there probably is a rather broad consensus among non-specialists (concerning Nazism) in the historical profession, as well as among the public in general, that there is a causal link between Nazi ideology and the Holocaust, people with no specialist knowledge about Communism in the USSR, China and Cambodia, such as the more than 500 signatories of the appeal against the enlightenment project about Communist regimes, deny that there is a corresponding link between Stalinist, Maoist and Cambodian Communism and the mass murders committed by these regimes.

It is a reasonable hypothesis that most of the signatories of the appeal referred to above did not regard themselves as defending crimes in the name of Communism. Rather, one is confronted with the counterpart to what Karin Kvist Geverts has labeled the "antisemitic background noise". The "communist background noise" comes from the idea that communism is to be thought of as immanently and essentially "good" and that consequently, all real existing historical communist regimes must be exempted from moral judgment.

\section{Living history in Sweden - beyond the Holocaust}

At the end of the first decade of the $21^{\text {st }}$ century, Swedish historical research on the topic of Sweden and crimes of Communist regimes was in the same stage as Swedish Holocaust research had been some thirty years earlier. The authors of Living History's report on the historiography on Communist crimes, Klas-Göran Karlsson and Michel Schoenhals from Lund University, ended their presentation with the following observation:

"How did Swedes, Swedish institutions and Sweden react to the crimes against humanity that were committed by communist regimes, both in the time when they were executed and after? In spite of remarkable recent research initiatives this is a field of research that is only budding." (Karlsson/Schoenhals 2008: 5) 
Half a century after the end of the Second World War, the shadow of Nazism returned in Swedish historical consciousness, but in a new way. The Swedish People's Home came in for critical scrutiny by both historians and journalists. Sweden's complicity in Hitler's policy was highlighted and what could be interpreted as totalitarian traits of the welfare state, i.e., compulsory sterilization of citizens, came into focus. In 1997, the Prime Minister Göran Persson rang the alarm bell concerning lack of historical knowledge about the Holocaust among Swedish youth. As a result, the Swedish Parliament decided to launch the educational project "Living history". Information on Nazism and the Holocaust was used as an instrument to combat xenophobia among the Swedish youth.

Ten years after the original initiative, in 2007, the Swedish government decided to let The Forum of Living history launch a second educational project. This time it was about crimes against humanity under Communist regimes. The appeal by more than five hundred Swedish historians and social scientists against this project can be interpreted as having been motivated by the fear that it would make possible "the identification of thought patterns and rhetorical figures in contemporary debates and politics" and compromise the Communist ideology. It is highly relevant to refer to the concept of "background noise" in this context. Kvist-Geverts demonstrated that it was not a matter of Swedish officials being antisemitic, but that the cases they handled involving Jews implied a discrimination against Jews in general. Similarly, those Swedish historical scholars and social scientists who do not want special enlightenment campaigns on Communist regimes in the contemporary world, especially those in China, Cuba and North Korea, must be suspected of harboring the view that Communist regimes should not be criticized to such an extent that Communist ideology as such becomes unattractive.

The quote in the preceding paragraph is taken from another context: the editors of the volume with articles on the Swedish Jewish refugee policy in 1920-1950 explicitly argued that their research was instrumental for making contemporary Swedish refugee policy humanitarian, because the historical knowledge concerning the earlier - inhuman treatment of refugees made possible "the identification of thought patterns and rhetorical figures in contemporary debates and politics". Andersson and Kvist-Geverts refer to racism, but the observation is also valid in respect to other ideologies, for example Communism. Whether some people hold that a communist background noise is good and beneficial does not detract from the general relevance of the observation (Andersson/Kvist Geverts 2008: 8). As a consequence of the creation of The Forum for Living History, Swedish historical science has been en- 
couraged to leave the academic ivory tower and engage in the education of Swedish youth and ordinary citizens about crimes against humanity.

\section{References}

Andersson, Lars M. (2002): "Review of Bauer, Yehuda, Förintelsen i perspektiv”. In: Historisk tidskrift, no. 4:2002, pp. 734-736.

Andersson, Lars M. (2003): "Att moralisera över det moraliska historiebruket”. In: Historisk tidskrift, no. 2:2003, pp 319-323.

Andersson, Lars M./Kvist Geverts, Karin (eds.) (2008): En problematisk relation. In: Flyktingpolitik och judiska flyktingar i Sverige 19201950, Historiska institutionen, Uppsala.

Andersson, Lars M./Tydén, Mattias (eds.) (2007): Sverige och Nazityskland. Skuldfrågor och moraldebatt, Dialogos, Lund.

Björlin, Lars (2001): "Russisk guld og svensk kommunisme,". In: Morten Thing (ed.), Guldet fra Moskva: finansieringen af de nordiske kommunistpartier 1917-1990, Forum, København, pp. 42 107.

Boëthius, Maria-Pia (1991): Heder och samvete: Sverige och andra världskriget, Ordfront, Stockholm.

Bolin, Sture (1944) Det ensidiga våldet. Spelet om krig och fred 19381939, Gleerups, Lund.

Bosworth, Richard B.J. (1994): Explaining Auschwitz and Hiroshima. Historians and the Second World War 1945-1990, Routledge, London.

Bruchfeldt, Stéphane/Levine, Paul (1997): ... om detta må ni berätta ... En bok om Förintelsen i Europa 1933-1945, Regeringskansliet, Stockholm.

Byström, Mikael (2006): En broder, gäst och parasit. Uppfattningar och föreställningar om utlänningar, flyktingar och flyktingpolitik i svensk offentlig debatt 1942-1947, Stockholms universitet, Stockholm.

Dietsch, Johan (2006): Making sense of Suffering. Holocaust and Holodomor in Ukrainian Historical Culture, Historiska institutionen, Lund.

Ekman, Stig, (1979): "Sverige under andra världskriget - erfarenheter från arbetet i ett projekt”. In: Historisk tidskrift (Stockholm): Vol. 99, pp. 152-165.

Ekman, Stig (2003): "Introduction”. In: Stig Ekman/Klas Åmark (eds.), Sweden's relations with Nazism, Nazi Germany and the Holocaust, Almqvist \& Wiksell International, Stockholm, pp. 11-30. 
Ekman, Stig (ed.) (1986): Stormaktstryck och småstatspolitik. Aspekter på svensk politik under andra världskriget, Liber, Stockholm.

Ekman, Stig/Edling, Nils (eds.) (1997): War experience, self image and national identity. Stockholm: Bank of Sweden Tercentenary Foundation [Riksbankens jubileumsfond].

Gerner, Kristian/Karlsson, Klas-Göran (2003): "Förintelsen - i historien eller över Historien?”. In: Historisk tidskrift, no. 2:2003, pp. 317318.

Gerner, Kristian/Karlsson, Klas-Göran (2005): Folkmordens historia. Perspektiv på det moderna samhällets skuggsida, Atlantis, Stockholm.

Heuman, Johannes (2006): "Conflicting Memories. The French Jews and Vichy France”. In: Klas-Göran Karlsson/Ulf Zander (eds.), The Holocaust on Postwar Battlefields. Genocide as Historical Culture, Sekel, Malmö, pp. 53-73.

Historieuppropet (2008): "Regeringen gör historia till ideologiskt slagfält”. In: Dagens Nyheter 2 April 2008, http://www.dn.se/opinion/ debatt/regeringen-gor-historia-till-ideologiskt-slagfalt-1.755817 and http://www.historieuppropet.se/undertecknare.htm (9 September 20 08).

Karlsson, Klas-Göran/Zander, Ulf (eds.) (2003): Echoes of the Holocaust. Historical Cultures in Contemporary Europe, Nordic Academic Press, Lund.

Karlsson, Klas-Göran (2003): "The Holocaust as a Problem of Historical Culture”. In: Klas-Göran Karlsson/ Ulf Zander (eds.), Echoes of the Holocaust. Historical Cultures in Contemporary Europe, Nordic Academic Press, Lund, pp. 9-57.

Karlsson, Klas-Göran/Zander, Ulf (eds.) (2006): The Holocaust on Postwar Battlefields, Sekel, Lund.

Karlsson, Klas-Göran/Zander, Ulf (eds.) (2004): Holocaust Heritage. Inquiries in European Historical Cultures, Sekel, Lund.

Karlsson, Klas-Göran/Schoenhals, Michael (2008): Brott mot mänskligheten under kommunistiska regimer. Forskningsöversikt, Forum för Levande historia, Stockholm.

Koblik, Steven (1988): The stones cry out. Sweden's response to the persecution of Jews 1933-1945, Holocaust Library (Sw. edition 1987) New York.

Kreth, Rasmus/Morgensen, Michael (1995): Flugten til Sverige. Aktionen mot de danske jøder oktober 1943, Gyldendal, Copenhagen.

Kulturhistoriska föreningen för södra Sverige (2004): Att överleva Röster från Ravensbrück http://www.kulturen.com/02_just_nu/04_ permanenta_utstallningar/Ravensbruck/Ravensbruck/index.htm 
Kvist Geverts, Karin (2008a): “'Fader Byråkratius’ rädsla för antisemitism. Attityder mot judiska flyktingar inom Socialstyrelsens utlänningsbyrå” In: Lars M Andersson/Karin Kvist Geverts (eds.), En problematisk relation. Flyktingpolitik och judiska flyktingar i Sverige 1920-1950, Historiska institutionen, Uppsala, pp. 73-94.

Kvist Geverts, Karin (2008b): Ett främmande element i nationen. Svensk flyktingpolitik och de judiska flyktingarna 1938-1944, Historiska institutionen, Uppsala.

Lajos, Attila (2004): Hjälten och offren. Raoul Wallenberg och judarna i Budapest, Svenska Emigrantinstitutet, Växjö.

Langmuir, Gavin (1996): Toward a Definition of Antisemitism. Berkeley, University of California Press, Los Angeles \& London.

Liljegren, Bengt (2004): "En ny syn på hjälten i Budapest”. In: Sydsvenska Dagbladet 26 May

Lindberg, Hans (1973): Svensk flyktingpolitik under internationellt tryck 1936-1941, Allmänna förlaget, Stockholm.

Lomfors, Ingrid (2002): "De Vita bussarna i koncentrationslägret Neuengamme: en intressekonflikt med förödande konsekvenser”. In: Historielärarnas Förenings Årsskrift, pp. 7-19.

Lomfors, Ingrid (2005a): Blind fläck. Minnen och glömska kring svenska Röda korsets hjälpinsats i Nazityskland 1945, Atlantis, Stockholm.

Lomfors, Ingrid (2005b): "Mörka fläckar på de Vita bussarna". In: Dagens Nyheter 26 January 2005, http://www.dn.se/kulturnoje/debatt-essa/morka-flackar-pa-de-vita-bussarna-1.349602.

Lundmark, Lennart (2004): "Raoul Wallenberg var inte ensam". In: Dagens Nyheter 24 March 2004.

Nilsson Nylander, Eva (2004): “Röster från Ravensbrück”. In: Historielärarnas Förenings Årsskrift, pp. 97-101.

OmKulturen: http://www.kulturen.com/03_om_kulturen/om_kulturen. asp on 22 September 2009

Persson, Sune (2002): 'Vi åker till Sverige'; de vita bussarna 1945, Fischer \& Co, Rimbo.

Persson, Sune (2003): "De vita bussarna och Folke Bernadotte". In: Historielärarnas Förenings Årsskrift, pp. 7-17.

Project-ravensbrück (2005): http://www.lub.lu.se/handskrift/projektravensbruck/projekt.html (on 25 January 2005).

Sniegon, Tomas (2008): Den försvunna historien. Förintelsen i tjeckisk och slovakisk historiekultur, Historiska institutionen, Lund.

Szulc, Artur (2005): Röster som aldrig tystnar. Tredje rikets offer berättar, Prisma, Stockholm. 
Tossavainen, Mikael (2006): Heroes and Victims. The Holocaust in Israeli Historical Consciousness, Historiska institutionen, Lund.

Tydén, Mattias (2002): Från politik till praktik. De svenska steriliseringslagarna 1935-1975, Stockholms universitet, Stockholm.

Universitetsbiblioteket Lunds Universitet (2005): Röster från Ravensbrück - ett unikt källmaterial från de överlevande vid mottagningen i Sverige 1945, http://www3.ub.lu.se/ravensbruck/.

Wahlbäck, Krister (2004). "Alltför ivrig nedskrivning av en hjälte", Svenska Dagbladet 25 April 2004.

Zander, Ulf (2006): "Wallenberg: Man and Myth". In: The Hungarian Quarterly, Vol. 47, Summer, pp. 166-168.

Zaremba, Maciej (1999): De rena och de andra; om tvångssteriliseringar, rashygien och arvsynd, Bokförlaget DN, Stockholm. 


\title{
Small and Moral Nations. Europe and the Emerging Politics of Memory
}

\author{
CeCILIE FELICIA StOKHOLM BANKE
}

Since the late 1990s, Denmark, Sweden and Norway have experienced an increased interest in the Holocaust as a history that should be addressed specifically. Best known is the process started in Sweden in January 2000 with the first Stockholm International Forum, where 40 states decided to make it a priority to keep the memory of the Holocaust alive. But also in Denmark and Norway, the Holocaust has been addressed specifically by several politicians, and both countries have officially apologized for their immoral conduct towards Jews; Denmark for denying 21 Jewish refugees entry from Germany in 1941, and Norway for participating in the systematic deportation of Norwegian Jews to Nazi Germany and to extermination camps. Considering the war record of Denmark and Sweden this development is surprising, especially compared to the development in other countries that were more directly affected by the war. Why should Sweden - a presumably neutral country during the war - go through such a process? And why should Denmark - a country with a reputation for its heroic rescue of the Danish Jews in October 1943 - engage in such soul-searching? ${ }^{1}$

1 This article is based on research in relation to the project "Holocaust Memory in Post-War Europe", conducted partly at the Danish Institute for International Studies, and partly during my stay as Visiting Professor and Fulbright-Scholar-in-Residence at the Strassler Family Center for Holocaust and Genocide Studies, Clark University. Parts of this research have been published in Wodak/Auer Borea (eds.), 2009 and Pakier/Stråth (eds.), 2010 
To answer these questions, we need to relate the developments in the Scandinavian countries to what Ariel Colonomos has termed the moralizing of international relations during the 1990s (Colonomos 2008). What we see during this decade is an increased interest in human rights and international humanitarian law: Sanctions, humanitarian interventions, and demands for "clean historical records". And this interest gives the Holocaust as a specific crime a new position in the political culture developing in Europe after the fall of Communism. With the growing interest in human rights comes a growing interest in how nations conducted themselves in the past. Addressing crimes of the past and demanding historical justice is a way to get access to the international political scene. The past has become a moral guidepost which aids countries to access to the international community - something of particular importance for small nations. (Reiter/Gärtner: 2001)

\section{The Stockholm Process in Denmark}

In Denmark, addressing the Holocaust specifically and investigating the country's share of responsibility happened mainly because of the Stockholm International Forums. Of course, Danish historians had shown an interest in Holocaust history before. But, the Holocaust was primarily seen as a German and a Jewish history where Denmark was generally not included. As the most dominant theme in Danish historiography, the history of the German occupation has been revised twice, influenced by two generational waves, with each new generation writing its own version of the national history. The first wave came during the 1970s, when a new generation of historians started questioning both the supposed heroism of the Resistance and the supposed innocent cooperation with the German occupiers. ${ }^{2}$ The second wave came during the 1990s, when journalists and young historians began to examine the Danish industrial and agricultural sectors and their cooperation - even collaboration with Nazi Germany. ${ }^{3}$

2 See among others Hans Kirchhoff, Augustoproret 1943, samarbejdspolitikkens fald, forudsatninger og forl $\phi b$. Et studie $i$ kollaboration og modstand, København: Gyldendal, 1979; Aage Trommer, Jernbanesabotagen i Danmark under den anden verdenskrig, Odense: Odense Universitetsforlag, 1971 and Henrik S. Nissen, $1940-$ studier $i$ forhandlingspolitikken og samarbejdspolitikken, København: Udgiverselskab for Danmarks nyeste historie, 1973

3 Joachim Lund, Danmark og den europaiske nyordning, det nazistiske regime og Danmarks plads i den tyske Grossraumwirtschaft 1940-42, ph.d.-afhandling, Københavns Universitet, 1999 and Hitlers spisekammer, 
In Denmark, this wave of new research emerging during the 1990s became the starting point of a public debate on national history, and paved the way for the Stockholm process to have an impact on Denmark. Here it is important to note that the new research, which showed other sides of the Occupation and the "innocent" cooperation with Nazi Germany, did not relate to the Holocaust. Denmark's Holocaust history remained basically uncontested until the late 1990s and the Stockholm process. We cannot give Sweden all the credit for the revision of Danish Second World War history, but it is doubtful that Denmark, with its highly prized self-image of resistance and rescue, would have felt obliged, without this process, to officially acknowledge its particular Holocaust guilt.

As such, the Stockholm process had a direct and immediate impact on Denmark. There had been no national commission in Denmark until, in the wake of the Stockholm International Forum in January 2000, the Danish Centre for Holocaust and Genocide Studies was established (Østergård 2000). The first major task of the Centre was a large research project focusing on the Danish policy towards Jewish refugees before and during the war. In early 2000, just after the first Stockholm International Forum, an article in the daily center-right newspaper Berlingske Tidende argued that during the Second World War Danish authorities refused 21 Jewish refugees from Nazi Germany entry into the country and sent them back to an unknown fate - ultimately death in Auschwitz. The story generated considerable controversy and the political response was a government-financed investigation into official Danish policy towards German-Jewish refugees from 1933 to $1945 .^{4}$

After 4 years of research, Prime Minister Anders Fogh Rasmussen issued an official apology at "Mindelunden", the national memorial park of the resistance fighters in Copenhagen. On the fourth of May 2005 Fogh Rasmussen stated:

"The remembrance of the dark aspects of the occupation era is unfortunately also a part of the celebration of the sixtieth anniversary of the liberation of

Danmark og den europaiske nyordning 1940-43, København: Gyldendal, 2005; Steen Andersen, Danmark $i$ det tyske storrum, dansk фkonomisk tilpasning til Tysklands nyordning af Europa 1940-41, København: Lindhardt \& Ringhof, 2003; Claus Bundgård Christensen, Niels Bo Poulsen \& Peter Scharff Smith, Under hagekors og Dannebrog, Danskere $i$ Waffen SS 1940-45, København: Aschehoug, 1998; Anette Warring, Tyskerpiger, $i$ krig og kxrlighed, ph.d.-afhandling, Roskilde Universitetscenter, 1993

4 Four volumes were published as a result of the Refugee Project, see Banke 2005; Kirchhoff 2005; Kirchhoff and Rünitz 2007; Rünitz 2005. 
Denmark. Thus I would very much like - on this very occasion and at this location - on behalf of the government and thus the Danish state, to express regret and apologize for these acts. An apology cannot alter history. But it can contribute to the recognition of historical mistakes. So that present and future generations will hopefully avoid similar mistakes in the future." (Rasmussen 2005)

What happened in Denmark because of the Stockholm process shows us how important it has become for small nations to admit crimes of the past. Some would even claim that Fogh Rasmussen instrumentalized the narrative about the Occupation when his liberal-conservative government broke the consensus on the course of Danish foreign policy by joining the Iraq coalition in 2003 and bringing Denmark into a new role in international activism. In a speech held during the commemoration of the August rebellion in 1943, when the Danes held a strike for the first time and thereby showed their resistance against the Germans, Fogh Rasmussen stated that the politics of cooperation was "a moral decline" (Rasmussen 2003a). No minister had ever openly questioned the hitherto solid consensus among historians and other scholars. What Denmark did during the Occupation was, up to that point, officially considered a wise policy for a small nation like Denmark. But Fogh Rasmussen challenged this consensus, and he did so just before the country entered the Iraqi war, introducing a new activist foreign policy for Denmark.

Looking back at the statement of Fogh Rasmussen, it is doubtful whether such a break would have been possible at all without the process started by the first Stockholm International Forum and the Stockholm Declaration. In that sense the Stockholm Declaration was not only a sign of the globalization of Holocaust memory. The Stockholm Declaration could also be seen as an international response to the growing impact of the past in our present political culture where the Holocaust has a unique and paradigmatic status.

\section{Europe after 1989}

Since the fall of the Berlin wall, the Holocaust has come to play an important role for Europe as a shared historical experience. We can see this not only in the many official apologies that European heads of states made during the 1990s, like the apologies offered by the French President, Jacque Chirac, in 1995, the Dutch Queen Beatrix also in 1995 and the Polish President in 2001. But also the resolutions adopted by the European Parliament to keep the memory of the Holocaust alive, and the 
Stockholm Declaration signed by European governments in January 2000, are evidence of a general acknowledgement in Europe of the Holocaust as a historical crime with a crucial place in European memory. As it is today, several European countries have adopted January 27 as their annual day of remembrance honoring the victims and their families. If we want to understand this development, we need to look back at what happened in Europe during the 1990s after the breakdown of Communism.

"This was the third time I had been confronted with the point zero of history", Croatian journalist, Slavenka Drakulic, writes in her book, They wouldn't hurt a Fly (2005).

"First time it had happened with my father's generation after the Second World War, that is, after the communist revolution. All history before then was rewritten. The second time was after the collapse of communism, when we had to forget about communism and begin again (and start rewriting history again) from the year 1990 . And the third time is now, the present, following the end of the last war." (Drakulic 2005)

Drakulic is referring to the civil wars in Ex-Yugoslavia that broke out in Sarajevo in 1995. What happened in the former Yugoslavia after the breakdown of Communism came as a shock to post-1989 Europe; a Europe full of hope and dreams for a new beginning. And new questions arose: What went wrong? How could Europe passively look on while their Serbian neighbors slaughtered 8000 Muslims? Had Europe not learned from the past? Was Europe about to repeat the same kind of madness, killing innocent civilians, as during the Second World War? Was ethnic nationalism coming back? Or rather, had ethnic nationalism really never disappeared?

The shock not only lead to a debate about Europe's unconfronted past, but contributed to an increased interest for the history of the destruction of European Jewry during the Second World War. And some countries established new research centers and public authorities, like in Denmark, Sweden, Norway and the Netherlands, with focus on the Holocaust and other genocides. In Europe, the emergence of a new academic field, genocide studies, following the wars in the Balkans was from the beginning closely linked to the history of the Holocaust. The Holocaust became the paradigmatic genocide for the study of other if not similar, then comparable crimes. (Gerner/Karlsson: 2005) Genocides were to be studied in a comparative context. And this gave the Holocaust a position as the historical crime that all European states should learn from. In order to prevent a similar crime, the lessons of the Holo- 
caust were to be taught and remembered. And the Holocaust was to be studied anew.

Although we cannot neglect the national differences in each European country, we can understand that what happened in Ex-Yugoslavia during the 1990s was nevertheless the beginning of an Europeanization of the Holocaust, both as history and as a moral guidepost. Within such a process, it is reasonable to ask in what way European societies have recognized and dealt with, in the words of Dutch researcher Alfred Pijpers their "Holocaust guilt" (Pijpers 2005). What are the mechanisms? Who are the agents, bringing justice to the murdered Jews? What is the relation between governments, the work of civil society organizations, and the changing social and political context in which the postwar trials took place?

Looking at this process more closely, we can observe a more intimate relationship between the national narratives in Western Europe and global human rights standards. During the past two decades, these standards have become increasingly influential in international politics, as described by among others Daniel Levy and Nathan Sznaider, Ariel Colonomos and Omer Bartov (Barkan 2000; Bartov et al. 2002; Colonomos 2008; DUPI 1999a; DUPI 1999b; Levy/Sznaider 2006). The increased influence of human rights in international politics and the growing interest for a revision of Second World War history brought European nation-states to confront their own human rights abuses, their own crimes of the past, their own dark sides. We have to understand this relation between an increased impact of human rights-thinking in international politics, and the revision of the history of the Second World War. Not only were national narratives being rewritten by a new generation, posing a series of new questions. History was also to be reinterpreted according to new moral standards, and these were for the generation of 1989, human rights.

Each country had to confront its atrocities from the past, and history was to be understood through the parameters of human rights, a change that to some historians seemed like a new kind of moralism. After the collapse of Communism, the need for some shared values within the EU became even more prevalent, especially after the integration of new member countries from Eastern Europe. And the shared values became tolerance, diversity, and respect for human dignity as stated in the preamble to the draft constitution of Europe, providing the EU an identity as a union working for and protecting basic human rights. As such, one can say that the growing interest for the Holocaust is conduced by an increased focus on international human rights. A development also pointed out by Sznaider and Levy in their book The Holocaust and Global 
Memory. To a certain extent we can also observe how these global human rights standards have actually challenged the national narratives, and perhaps stimulated a change in the ways national history is being understood and interpreted.

By examining the ways the Holocaust has been dealt with in postwar Europe, we can thus distinguish some general dynamics of how societies have dealt with their National Socialist past. Secondly, we can also describe how globalization affects the ways history is being interpreted. And, thirdly, we can discuss whether this globalization of history can stimulate a change in national identities. Does the Holocaust as a paradigm stimulate a denationalization, perhaps even an Europeanization, of the past, in which individualized religious and cultural identities replace the national identities? Or, should we turn the question around and instead ask: Is the crucial role of the Holocaust in European public memory in fact a reflection of a process in which European nation states becomes increasingly less national?

\section{Holocaust memory}

Going deeper into my subject, I want to emphasize that not only has the Holocaust been incorporated into European public memory as a specific crime. During the past decade, research into Holocaust memory has also increased considerably. A recently completed project at Lund University, Sweden, The Holocaust and European historical cultures, describes through a series of case studies how the history of the Holocaust has been used in several European countries for either educational, political or societal purposes. Among other results, this project shows that for some countries, such as Sweden, the Holocaust serves as a moral legacy to educate younger generations and teach them tolerance and nondiscrimination. A tendency repeated in Denmark, Norway, France, UK and the Netherlands. (Banke 2008; Brudholm/Mennecke 2004 Karlsson/Zander 2003, 2004, 2006). For others, like Slovakia and the Czech Republic, the demands from the European Union to confront and remember the Holocaust is experienced like a dictate coming from above (Sniegon 2008), and has now resulted in a request for a similar focus within the European Union on the crimes of Communism. ${ }^{5}$ Thus, this research project has shown us to what extent history can serve a society and be used for different purposes.

5 European Parliament resolution of 2 April 2009 on European conscience and totalitarianism. 
Another aspect that has unfolded during these years is how the prosecution of crimes committed during the Second World War can affect a society, also in a longer perspective, and how it can, in some cases, stimulate a debate about what was previously neglected by the public, as described by Devin O. Pendas in The Frankfurt Auschwitz Trial, 19631965 (Pendas 2005), and by British historian Tony Judt in Postwar (Judt 2005). Even though it can be questioned whether trials have a moral impact on a society, they often do influence the public discourses as shown by Joan B. Wolf in Harnessing the Holocaust. The Politics of Memory in France (Wolf 2004).

As such, research into the dynamics of postwar trials, how they operate in different societies, and the relations between trials and the public, can provide a more profound knowledge of the relation between law and history. It can also leave us with a clearer perspective of the agents seeking justice on behalf of the victims, such as Simon Wiesenthal and Serge Klarsfeld, and what role these advocates have played. Why did some societies avoid bringing Nazi war criminals to justice? And why did others not? What can we more generally say about the way a society uses legal instruments to confront atrocities of the past? To what extent do trials stimulate a re-evaluation of history, perhaps even a revision? And can public opinion and pressure from interest groups influence policy making and legislative processes? Is there a general pattern that we can apply to all societies?

How societies remember the past, and also how the history of the Second World War is being written and rewritten, is a scholarly field that has expanded both in Europe and in the USA during the past one or two decades. (Assmann 2007, 2008; Connerton 1989; Herf 1997; Kushner 1994; Rousso 1991; Warring 2002; Welzer 2002). Based on French sociologist Maurice Halbwalchs' concept of collective memory, Peter Novick has described how the Holocaust was integrated into American collective memory (Novick 1999). Also Jeffrey Klick uses Halbwachs to discuss the relation between collective memory and historical responsibility in Germany. The field now includes studies on lieux de mémoire sites of remembrance - and on politics of remembrance (Kroh 2008; Lebow 2006; Young 1993). However, few studies consider the influence of globalization and how global moral standards help develop what Sznaider and Levy term "cosmopolitan memory".

Through examining the ways German, Israeli and American societies have remembered the Holocaust, Sznaider and Levy show, how ethnic-group politics, coupled with popular culture, have been powerful enough to force to introduce an alternative remembrance of the Holocaust. Thus, examining how European societies started to remember the 
Holocaust and what influence global media and cultural representations had on this process, can help us to understand why the Holocaust during the past two decades has gained such a prominent position in European memory. ${ }^{6}$ Such an examination can also lead us to a better understanding of the relation between the breakdown of Communism, the increasing role of international human rights standards in politics, and the Holocaust as a global symbolic reference.

\section{The four phases of Holocaust memory}

For a general overview, I have found it necessary to divide the ways the Holocaust has been dealt with, or not dealt with, into four chronological phases. The phases are defined by the development mainly in the United States, Israel, Germany and France, and what generally characterizes these phases. My phase model was originally inspired by Tony Judt's Postwar, and later the work of German memory scholar, Aleida Assmann. Generally most scholars would agree with this relatively rough structure for postwar Holocaust memory, even though my terminology can be contested:
- 1945-1949
Confrontation
- $1950 \mathrm{~s}$
Interpretation
- 1960s-1990s
Justice
- 1990s-
Remembrance

The four decades of Soviet influence, however, add additional layers of complexity leading to important differences between East and West European states, but generally we can speak of four phases. Each is defined by social, political and cultural developments, beginning in the immediate postwar days, with the direct Confrontation of the public in the West to the crimes of the Nazis. Here, the public in Germany, in the UK, and in the liberated countries were confronted with the horrors that had taken place in the camps. The confrontation was immediate and short-lived, and was followed by silence. Even if the world became aware, it was as if the realization of the immense crime did not follow until two decades later at a time when the affected countries were better prepared.

The second phase I have termed Interpretation. Even though silence replaced the immediate confrontation, and Europe was busy recovering economically from the war, artists and writers started to articulate what

6 See also the contribution by Bjerg in this volume for an empirical example of the influence of media on the memory culture of the Holocaust. 
otherwise seemed too monstrous to describe. What we see during the silent 1950s are some of the first artistic interpretations of the Holocaust emerging, mainly by Jewish-American émigré and refugee artists. These were artists who themselves had been in the camps or, like the Italian Corrado Cagli, were on the spot when the American soldiers entered Nordhausen and Buchenwald. And it was the Italian-American painter Rico Lebrun who used photographs from Buchenwald in the 1950s to speak of the human condition, the pain, the endurance, and the salvation. Pictures of emaciated concentration camp inmates, with shaven heads and naked, were used to say something general about Western culture: attitudes to death, the fragility of the individual, the myth of Christ, victimization, redemption.

As early as Lebrun's work in the USA in the 1950s, the Holocaust had a symbolic value. For the Russian-born, Boris Lurie, a decade later the Holocaust was a key to his iconoclastic NO! art. Lurie was himself a survivor of the camps, and after the war he settled in New York where he established himself as an artist. In his work, the Holocaust expressed a profound disillusion with the free Western world. He made collages of photographs from the camps and pornographic images. One of them, "Lolita" (1962), has bits of the poster for Stanley Kubrick's film of the same name combined with three dead camp prisoners whose shaven heads stick out from behind a wooden barracks. What Lurie wanted to show with this particular arrangement was clarified in 1998: "My pictures are less to do with the Holocaust than with discontent with the American way of life". 7

Already then, with these first interpretations, the Holocaust had taken on a symbolic value (Banke 2005a; Liljefors 2002). An artist like Lurie referred to the Holocaust as a symbol for the degenerated Western culture and capitalism. Later, in 1996, the Polish artist, Zbigniew Libera, would have his installation LEGO Concentration Camp for the Venice Biennale accompanied by the following comment:

"I was thinking about such kinds of architecture which could be a factor of transformation of individuals: the architecture which influences those whom it shelters, which provides control, subordinates individuals to cognition and modifies them through discipline. All the aspects can be found in architecture of a cloister, a hospital, soldiers barracks, a school, a factory or a prison [...]" Most scholars now agree that the breakthrough for global Holocaust awareness came with the transmission of the popular television series, Holocaust: The Story of the Family Weiss, in 1978 and 1979 (Judt 2005;

7 Quoted in Liljefors 2002.

8 Quoted from Lijefors 2002, p. 153 
Karlsson/Zander 2003; Zander 2003). But Holocaust, and its popular success, would not have been possible without the national trials that took place in Germany and elsewhere in Europe from the late 1950s through the 1960s and 1970s, and the concurrent publication of important scholarly works, documenting the Holocaust as a crime in and of itself. Thus, the third phase is characterised by Documentation and, to some extent, the pursuit of justice. It is during this third phase that the Holocaust is regarded as a deliberate crime, a genocide, and the dimensions of the anti-Jewish policy of the Nazis are introduced to the public by a new generation of scholars who based their works on archival research (Davidowitz 1975; Friedländer 1966; Hilberg 1961).

It is important to emphasize this interdependent relationship between research, the trials in Germany and later in France, and the continuous striving for justice on behalf of the Jewish people. The discussion about the meaning or effect of trials not only for different societies, but also for the understanding of history, was introduced by Hannah Arendt when she questioned the Eichmann trial's legitimacy (Arendt 1994 [1963]). Arendt's reflection gave rise to a still ongoing discussion among philosophers and lawyers, but also historians, about to what extent trials can be used for writing history. Every court operates - from a historian's point of view - with a limited vision of the past. The court can only judge the past according to the evidence available to it. Thus, the International Military Tribunal at Nuremberg is a reflection of the prosecuting countries' interpretation of the Second World War at that time (Finkielkraut 1992; Marrus 2002; Paxton 2001).

The fourth phase is characterized by an increased activity of remembrance, starting out in the mid 1990s with a number of resolutions adapted at European level and several official acknowledgements offered by heads of states, like the French President in $1995 .{ }^{9}$ On the $53^{\text {rd }}$ anniversary of the round-up of Parisian Jews, France's newly installed president, Jacque Chirac, broke the taboo and acknowledged his country's role in the Holocaust (Banke 2010). This phase was clearly dependent on the historical documentation, the trials, and the quest for justice for the murdered Jews. Combined with the $50^{\text {th }}$ anniversary of the end of the Second World War and the ongoing civil wars in ExYugoslavia, a certain political momentum was created that united European political leaders around the imperative to keep the memory of the Holocaust alive.

9 Resolution on European and international protection for Nazi concentration camps as historical monuments, 1993 and Resolution on a day to commemorate the Holocaust, 1995. 
I am well aware of the risk of oversimplification inherent in creating such a chronological model of the phases of how the Holocaust has been dealt with in memory culture, and that some of the phases overlap. Nevertheless, this model provides a structure that can help to identify more general patterns and dynamics. What the model shows is not only how the Holocaust as a specific crime has developed from being basically ignored to being acknowledged and remembered. The model also provides an overview of how historical crimes are being addressed, under which circumstances and by whom. Through such a chronological phase model, actors and agents become visible, and cases are more easily compared at a concrete level.

However, in order to conduct such a study, we cannot simply observe and describe. We have to add theories. Within memory studies, different concepts and theories have been suggested, like "collective memory" originally introduced by Maurice Halbwachs in 1925, "historical culture" introduced by Paul Connerton (1989), and "historical consciousness" used by, among others, the Danish historian Bernard Eric Jensen (1994) ${ }^{10}$. The concept of "collective memory" can be criticized for being an organic metaphor, not suitable for modern societies, as suggested by memory scholar Aleida Assmann (Assmann 2007, 2008; Connerton 1989; Jensen 1994). Instead, we need to look at theories of globalization and social change. The relation between globalization, social change, and the development of new kinds of identity with new historical orientations can be described through theories of nation building, as developed originally by Benedict Andersson, Ernest Gellner and Anthony D. Smith, and theories of "de-nationalizations", as described by Georg Delanty and Bryan S. Turner (Andersson 1991; Gellner 2006 [1983]; Smith 1999, 2000). With globalization, a new kind of citizenship, based less on national identities, has emerged, leaving room for other forms of identity making (Delanty 2000; Turner 2001).

The current phase, Remembrance, is thus deeply dependent on the political development during the 1990s, and can to some extent be related to the denationalization of European national identities. In a united Europe, the Holocaust has come to represent some shared and European values. However strange it may sound, there is a general agreement within Europe that the Holocaust represents a unique historical lesson, and that the shared European values stem from this lesson.

And therefore, we may say that the Holocaust as a specific field of study stimulates a certain degree of denationalization of national narra-

10 See the contributions by Gerner and Körber for elaborations on the concepts of history culture and historical consciousness respectively. 
tives, maybe even a Europeanization, leaving room for other narratives more closely related to individual minority groups based on their religious and cultural traditions. As such, the increased interest for the Holocaust in Europe during the past two decades is also a sign of fundamental changes taking place during these years in many European societies.

\section{The legacies of the Holocaust in Scandinavia}

Returning to my initial inquiry of the Holocaust as a moral guidepost and of how small states like the Scandinavian relate to their national pasts, we can see how in the case of Denmark and Norway these states have addressed the Holocaust as a specific crime. Until the end of the 1960s, the rescue of the Danish Jews was not paid any specific attention, and when it finally did, it happened as a consequence of a development taking place outside Denmark. Since the liberation, the rescue of the Danish Jews was seen as an integrated part of the resistance and the history of the Occupation. But as the international interest for the persecution of extermination of the Jews during the Second World War grew, the more narrow national interpretation of the Danish rescue was challenged from various sides.

In 1963, the organization "Thanks to the Danes" (later renamed "Thanks to Scandinavia") was launched by Richard Netter and Victor Borge as a means of expressing appreciation to the Scandinavian people for their heroism. The Danish prime minister, social democrat Jens Otto Krag, attended the opening event, and Netter later told how Krag had a hard time understanding the purpose of it all. "Why pay homage to the Danes?" Krag asked Netter at the ceremony. ${ }^{11}$ Also in 1963, the Danish Resistance as a collective was among the first to be included in Yad Vashem's Righteous among the Nations because of its perceived pivotal role in the rescue. The following year Leni Yahil published The Rescue of Danish Jewry. A Test of Democracy. For the first time, the rescue of the Danish Jews was interpreted in a wider frame of a European Holocaust (Bak 2001: 173). In brief, Yahil argues that the Danish Jewry was saved because of strong democratic traditions in Denmark. This interpretation has shown a remarkable persistence.

The articulation of the Danish rescue as a light in the darkness took place abroad, but was brought to Denmark through events and initiatives like the one mentioned above. In the end, the international interpretation

11 Richard Netter interview in the Danish newspaper Politiken 11 March 1993. 
of the rescue action did not break with the dominant narrative about the occupation. On the contrary, Danes rescued the Jews, and again it was demonstrated how Danish democracy could not be defeated by Nazism. Even though Denmark was occupied and the Danish authorities did cooperate with the Nazi regime, it was only in order to save the Danish democracy and society.

The example of the starting point for the commemoration of the rescue of the Danish Jews, shows how national narratives become influenced, and in some cases also challenged by international moral standards. The peculiar thing here is that Denmark was at the time not even aware of this relation. One reason could be that the growing international interest for the Danish rescue did not contest the dominating national narrative about the occupation. The overall conclusions remained the same, and until the late 1990s, the darker sides of Danish occupational history remained unaddressed.

Looking at Norway, we see a similar development following the Stockholm process, even though Norway's war record is very different from both Denmark's and Sweden's. Norway was occupied like Denmark, but Norway not only collaborated with the Nazi authorities. Norway also showed much stronger and more direct violent resistance before accepting the Occupation, and unlike Denmark, nearly $40 \%$ of the Norwegian Jews were deported, to some extent even with the help of locals. In this sense, with Norway we have a case more similar to other European countries.

Belgian historian Pieter Lagrou (2000) has examined how the memory of the Second World War is presented in a national and patriotic narrative in Belgium, France and the Netherlands. He has discovered that within this narrative there is little space for the commemoration of events or groups whose history and experiences could not be utilized for postwar recovery. One of these groups was the national Jews, whose war experience was not only radically different from that of most of their countrymen, but whose experiences could not be used within a meaningful national narrative. By presenting the deportation of Jews as a solely German affair and completely at odds with what was considered to be the Norwegian core values, the memory of what had happened to Norwegian Jews could serve a purpose within the national narrative.

As the Norwegian historian Ingrid Brakstad writes, the symbolic embracement of the Jews and their suffering was portrayed as natural to all "good Norwegians." This rhetoric depicted Norwegians as protectors of "their" Jews, and as immune to anti-Semitic influences. The fact that Norwegians had participated in the deportations of Jewish countrymen and that Norwegians were not, in fact, immune to anti-Semitism was 
hardly ever an issue in this context. This way the memory of the Jewish experiences could serve a purpose in the national epos needed in the postwar years - as a symbol of German cruelty and Norwegian humanism (Brakstad: 2007).

So, to conclude, the Stockholm process clearly challenged the national narratives in these countries with demands of adjusting to international moral standards. Not least in the Danish case we see a widely respected narrative, namely the one on the Danish rescue of Jews in October 1943, being challenged as a consequence of the Stockholm process. The logic behind the Danish "breaking silence" is of course that Denmark is such a pure and moral nation, that it can afford to acknowledge this particular dark side of the past. And through this acknowledgment gain this important access to the international community.

\section{References}

Andersson, Benedict (1991): Imagined Communities. Reflections on the Origin and Spread of Nationalism, Verso, New York/London.

Arendt, Hannah (1994 [1963]): Eichmann in Jerusalem. A Report on the Banality of Evil, Penguin Classics, New York/London.

Assmann, Aleida (2007): Geschichte im Gedächtnis. Von der individuellen Erfahrung zur öffentlichen Inszenierung, Verlag C. H. Beck, München.

Assmann, Aleida (2008): “Transformations between History and Memory”. In: Arien Mack/William Hirst (eds.), Collective Memory and Collective Identity, Social Research, 75(1), Spring 2008, pp. 4972.

Bak, Sofie Lene (2001): Jødeaktionen oktober 1943. Forestillinger i offentlighed og forskning, Museum Tusculanums Forlag, København.

Banke, Cecilie Felicia Stokholm (2005a): "Holocaust and the decline of European values". In: Klas-Göran Karlsson/Ulf Zander (eds.), Holocaust Heritage. Inquiries into European Historical Cultures, Sekel Bokförlag, Malmö, pp. 87-104.

Banke, Cecilie Felicia Stokholm (2005b): Demokratiets skyggeside. Flygtninge og menneskerettigheder i Danmark før Holocaust, Syddansk Universitetsforlag, Odense.

Banke, Cecilie Felicia Stokholm (2008): "Sarkhozy og Vichysyndromet”, DIIS-brief, Copenhagen, December 2008.

Banke, Cecilie Felicia Stokholm (2010): "Remembering Europe's Heart of Darkness”. In: Małgorzata Pakier/Bo Stråth (eds.), A European 
Memory? Contested Histories and Politics of Remembrance, Berghahn Books, Oxford, pp. 163-174.

Barkan, Elazar (2000): The Guilt of Nations: Restitution and Negotiating Historical Injustices, Johns Hopkins University Press, Baltimore.

Bartov, Omer/Grossman, Atina/Nolan, Mary (2002): Crimes of War: Guilt and Denial in the Twentieth Century, New Press, New York.

Brakstad, Ingjerd Veiden (2007): "Okkupasjon, motstand og myter Den patriotiske minnekulturen og jødeforfølgelserne”. In: Fortid nr. 2-2007, pp. 9-15.

Brudholm, Thomas \& Martin Mennecke (eds.) (2004): Erindringens Fremtid, Lindhardt og Ringhof, København.

Colonomos, Ariel (2008): Moralizing International Relations: Called to Account, Palgrave Macmillan, New York.

Connerton, Paul (1989): How Societies Remember, Cambridge University Press, Cambridge.

Delanty, Gerard (2000): Citizenships in a Global Age, Open University Press, Buckingham.

Davidowitz, Lucy (1975): The War Against The Jews, 1933-1945, Bantam, New York.

Drakulić, Slavenka (2005). They would never hurt a fly: war criminals on trial in The Hague, Abacus, London.

DUPI (1999a) Dansk Udenrigspolitisk Institut (DUPI), FN, Verden og Danmark, København.

DUPI (1999b): Dansk Udenrigspolitisk Institut (DUPI), Humanitarian Intervention. Legal and Political Aspects, København.

Finkielkraut, Alain (1992): Remembering in Vain. The Klaus Barbie Trial and Crimes Against Humanity, Columbia University Press, New York.

Friedlander, Saul (1966): Pius XII and the Third Reich: A Documentation, Knopf, New York.

Gellner, Ernest (2006 [1983]): Nations and Nationalism, Blackwell Publishing, Oxford.

Halbwach, Maurice (1992 [1925]): On Collective Memory, Heritage of Sociology Series, University of Chicago Press, Chicago.

Herf, Jeffrey (1997): Divided Memory: The Nazi Past in the Two Germanys, Harvard University Press, Cambridge.

Hilberg, Raul (1961): The Destruction of The European Jews, W.H.Allen, London.

Jensen, Bernard Eric (1994): Historiedidaktiske Sonderinger bd. I, København: Institut for historie og samfundsfag, Danmarks Lærerhøjskole. 
Judt, Tony (2005): Postwar. A History of Europe since 1945, Penguin Press, London.

Karlsson, Klas-Göran/Gerner, Kristian (2005): Folkmordens historia, Atlantis, Stockholm.

Karlsson, Klas-Göran/Zander, Ulf (eds.) (2003): Echoes of the Holocaust. Historical Cultures in Contemporary Europe, Nordic Academic Press, Lund.

Karlsson, Klas-Göran/Zander, Ulf (eds.) (2004): Holocaust Heritage. Inquiries into European Historical Cultures, Nordic Academic Press, Lund.

Karlsson, Klas-Göran/Zander, Ulf (2006): The Holocaust on Post-War Battlefields. Genocide as Historical Culture, Sekel Bokförlag, Malmö.

Kirchhoff, Hans (2005): Et menneske uden pas er ikke noget menneske, Syddansk Universitetsforlag, Odense.

Kirchhoff, Hans/ Rünitz, Lone (2007): Udsendt til Tyskland, Syddansk Universitetsforlag, Odense.

Kroh, Jens (2006): Transnationale Erinnerung: Der Holocaust im Fokus geschichtspolitischer Initiativen, Campus Verlage, Frankfurt.

Kushner, Tony (2004): The Holocaust and the Liberal Imagination, Blackwell, Oxford.

Lagrou, Pieter (2000): The Legacy of Nazi Occupation. Patriotic Memory and National Recovery in Western Europe, 1945-1965, Cambridge University Press, Cambridge.

Lebow, Richard Ned (2006): "The Memory of Politics and Postwar Europe". In: Irchard Ned Lewbow/ Wulf Kansteiner/Claudio Fogu (eds.), The Politics of Memory in Postwar Europe, Duke University Press, London, pp. 1-39.

Levy, Daniel/Sznaider, Nathan (2006): The Holocaust and Memory in the Global Age, Temple University Press, Philadelphia.

Liljefors, Max (2002): Bilder av Förintelsen: mening, minne, kompromettering, Palmkron, Lund.

Marrus, Michael (2002): "History and the Holocaust in the Courtroom". In: Ronald Smelser (ed.), Lessons and Legacies V. The Holocaust and Justice, Northwestern University Press, Evanston, pp. 215-239.

Novick, Peter (1999): The Holocaust in American Life, Houghton Mifflin Company, New York.

Pakier, Malgorzata/Stråth, Bo (eds.) (2010): A European memory?: contested histories and politics of remembrance, Studies in Contemporary European History, Volume 6, Berghan Books, New York.

Paxton, Robert (2001): Vichy France: Old Guard and New Order, Columbia University Press, New York. 
Pendas, Devin (2006): The Frankfurt Auschwitz Trial, 1963-1965. Genocide, History and the Limits of the Law, Cambridge University Press, Cambridge.

Pijpers, Alfred (2006): "Now We Should All Acknowledge our Holocaust Guilt”, in Europe's World, Autumn 2006.

Reiter, Eric/Gärtner, Hans (2001): Small States and Alliances, PhysicaVerlag, Vienna.

Rasmussen, Anders Fogh (2005): In: Berlingske Tidende, 5 May 2005

Rasmussen, Anders Fogh (2003a): "60 året for 29. august 1943”, Speech 29 August.

Rasmussen, Anders Fogh (2003b): "Visioner om Danmarks aktive Europapolitik", Speech 23 September.

Rousso, Henry (1991): The Vichy Syndrome, History and Memory in France since 1944, Harvard University Press, Cambridge.

Rünitz, Lone (2005): Af hensyn til konsekvenserne. Danmark og flygtningespørgsmålet 1933-1940, Syddansk Universitetsforlag, Odense.

Smith, Anthony D. (1999): Myth and Memories of the Nation, Oxford University Press, Oxford.

Smith, Anthony D. (2000): The Nation in History. Historiographical Debates about Ethnicity and Nationalism, Brandeis University Press, Hanover, New England.

Sniegon, Tomas (2008): Den Försvunna Historien. Förintelsen i tjeckisk och slovakisk historiekultur, Lund University, Lund.

Turner, Bryan S. (2001): “The Erosion of Citizenship". In: British Journal of Sociology 52(2), pp. 189-209.

Warring, Anette (2002): "Demokratische Erinnerungspolitik zwischen stabilen Werten und Reflexivität”. In: Claudia Lenz et al. (eds.), Erinnerungskulturen im Dialog. Europäische Perspektiven auf die NSVergangeheit, UNRAST, Hamburg/Münster, pp 19-32.

Welzer, Harald/ Tschuggnall, Karoline/Moller, Sabine (2002): Opa war kein Nazi. Nationalsozialismus und Holocaust im Familiengedächtnis, S. Fischer Verlage, Frankfurt a. M.

Wodak, Ruth/Auer Borea, Gertraud (eds.) (2009): Justice and Memory. Confronting traumatic pasts. An international comparison, Passagen Verlag, Vienna.

Wolf, Joan B. (2004): Harnessing the Holocaust. The Politics of Memory in France, Stanford University Press, Stanford.

Young, James (1993): The Texture of Memory. Holocaust Memorial and Meaning, Yale University Press, New Haven.

Zander, Ulf (2003): "Holocaust at the Limits. Historical Culture and the Nazi Genocide in the Television Era". In: Klas-Göran Karlsson/Ulf 
Zander (eds.), Echoes of the Holocaust. Historical Cultures in Contemporary Europe, Lund University, Lund, pp. 255-292.

Østergård, Uffe (2000): "Holocaust, folkedrab, folkemord og europæiske værdier". In: Folkemord, Den Jyske Historiker, Nr. 90 December, pp. 14-38. 

II Historical Consciousness in HistoRy DIDACTICS 



\title{
Processing Time - On the Manifestations and Activations of Historical Consciousness
}

\author{
KLAS-GÖRAN KARLSSON
}

The little girl sat by her grandmother's kitchen table. The old woman told her about her childhood, several decades ago. The girl was bored. She did not understand why Grandma had not attended school, and why she said nothing about television programs and computer games. Trying to catch the attention of her granddaughter, the old woman anxiously waved her hands. The girl's eyes fell on her grandmother's palm, wrinkled and rough after many years of manual labor. Then she looked at her own soft and smooth hand. Suddenly a historical thought crossed her mind: once upon a time Grandma's palm had been as soft and smooth as her own. Immediately, another thought, at least as well-advised as the first but rather future-oriented, came to her mind: in time, her own palm will also be wrinkled and rough. Thus, in a single line of thought, the little girl had depicted herself as a historical individual. She had entered into a mental process in which notions of the past and of the future became integrated aspects of her understanding of present life. The effort rapidly turned the strangeness and difference of her grandmother's childhood into a notion of identity and familiarity. Consequently, the girl had put her historical consciousness to work.

\section{Temporal orientation}

Historical consciousness is an essential dimension of our moral, emotional and cognitive thinking and orientation. It is a time compass that assigns meaning to past events and directs us towards future projects. It 
is connected not only nor even primarily to scholarly historical interpretations, but to meanings, memories, metaphors, monuments and myths. Thus, historical consciousness is a basic faculty of temporal awareness without which there would be no humanity in either of the two meanings of the word; that is, no humaneness and no mankind. As human beings, we may lack knowledge of many things that have happened in the past, being totally unfamiliar with diverging scholarly interpretations of feudalism or the French revolution, but we cannot do without historical consciousness.

Although the phraseology relating to historical consciousness is often as pretentious as the lines above, historical consciousness is normally at work in everyday situations, in history classes and in other kinds of direct human interaction, as the example with the little girl and her grandmother clearly demonstrates. However, it is also present in our indirect encounters with history by means of texts or other objectifications of history. From this there follows that historical consciousness must be analytically connected to history in both its basic dimensions: as res gestae, or what has actually happened in the past, and to historia rerum gestarum, or how we represent and use this past. Consequently, historical consciousness can and must be approached historically as well as functionally. Historical consciousness is certainly historical, changing from time to time and from one society to another. However, it would be just as adequate to use the term "history consciousness", since it highlights a mental activity in which history is functionally processed.

But how do we actually recognize historical consciousness when we see it? Questions of this kind can be multiplied: Is there a straightforward way to translate historical consciousness into a couple of educational competences, needed in a modern democracy? This seems to be assumed when educational history programs declare it a primary objective that students should develop or deepen their historical consciousness. Or, to reverse the questions, which makes them even more problematic: If historical consciousness, as is often argued, is a totality or an inclusion that mentally embraces the three temporal perspectives past, present and future in a complex pattern of condensation and crystallization, what is not part of historical consciousness? If historical consciousness is in everything and everywhere, where does it analytically start and end?

It would probably be safe to say that most of us content ourselves with using the concept in a heuristic way. It helps us to raise new questions about the historical dimension itself and its functions and uses in society. In my mind, this is the way it should be. Thus, it reminds us that history often functions and is used differently from scholarly history, 
when related to what the phenomenologically inspired Germans denote as Lebenswelt. But while concepts such as historical culture and collective memory have been successfully made use of as analytical tools to better understand how history works in human life and society, historical consciousness has not. It seems to me that we still rely heavily on the definition given in the first Handbuch der Geschichtsdidaktik from 1979, in which Karl-Ernst Jeismann defined historical consciousness as den Zusammenhang von Vergangenheitsdeutung, Gegenwartsverständnis und Zukunftsperspektive, "the interrelation between interpretation of the past, understanding of the present and perspective on the future" (Jeismann 1979: 42). ${ }^{1}$ This definition is, in my opinion, still valid, but should be elaborated, since it gives few indications of how historical consciousness works in life and society. The purpose of my contribution is in part to reflect theoretically on the concept, and in part to offer a few modest proposals on how historical consciousness can be analyzed in a more productive way in history-cultural studies.

\section{The return of historical consciousness}

Let me start from two notions: first, that right now there is an interest in and a need for an expanded concept of historical consciousness. Secondly, that the work done so far in terms of providing it with analytical qualities has been unsatisfactory. How should we understand the current interest in historical consciousness? Undoubtedly, there is an internal scholarly answer. This does not only come from the obvious fact that a focus on phenomena of "being" has given way to a focus on phenomena of "consciousness". This "cultural turn" has actively demonstrated that language and culture serve to promote the kind of time transgression involved in historical consciousness. The argument, mainly but not only derived from hermeneutical philosophy, goes: in contemporary language and other cultural expressions, past experiences are collected and made use of. But future experiences are also anticipated, because in our contemporary perceptions and interpretations they are ranged in and influenced by linguistic and cultural structures that had existed before the experiences were collected and made use of. In particular, Hayden White has called attention to the "figurative imagination" involved beforehand in all approaches to history (White 1985: 101-120).

1 The same definition is repeated in later editions of the handbook from 1985 and 1997. 
This perspective illustrates the important question of whether history as a phenomenon of consciousness fulfils beneficiary orientative, sensegiving functions, or whether such "pre-givens" demonstrate the malevolently repressive or narrowly ideological risks inherent in any use of history. Is historical consciousness, with its focus on constancy and internal coherence, primarily connected to canonicity and hegemony, or can it further pluralist meanings and openness? There is a general idea, propounded already by Friedrich Nietzsche and Max Weber, that the appearance of modern society coincided with a new, more instrumental relationship to time and history. An objectively measured and understood sense of time replaced the subjective relationship to time predominant in pre-modern and early modern society. In Reinhart Koselleck's terminology, modernization meant that the human horizon of expectations became estranged from the space of experiences of human beings (Koselleck 1985).

It goes without saying that the professionalization of history scholarship was part of the same process. For some present-day commentators, this development went a long way in colonizing or usurping the historical dimension from every-day life. In the bitter words of Nietzsche, historical scholarship interposed itself as a gleaming but hostile star between history and life (Nietzsche 1983: 77). ${ }^{2}$ For others, the development of history scholarship is on the contrary essential for the growth of historical consciousness. They have rather blamed the extreme ideological and scholarly modernism of the last century for removing history from life and society (Schorske 1998). This debate, which generally can be interpreted as a dispute between those who judge historical scholarship as being the prime mover and benefactor of historical consciousness, and those who maintain that historical consciousness is part of a much wider socio-cultural process, is in itself no salient part of this analysis. Nevertheless, it may say something important about the temptations and prospects inherent in the concept of historical consciousness.

What unites the opponents is a belief in the need to regain a lost historical consciousness in order to solve various problems and crises of modernity, and to provide a "post-modern" individual and society with a more "vertical" identity, by promoting integration into processes of meaning considered time-transgressing, such as ethnification, Europeanization and victimization. All of these depart from the wide temporal realm of historical consciousness, and from a range of questions with

2 Among later proponents of such a critical perspective can be mentioned Raphael Samuel (1994: 3-8). 
temporal extensions: Who are "we"? Who are "the others"? From where do we originate? Where did it go wrong? Where are we going?

Historical consciousness stands out as an indispensible theoretical, heuristic concept if we want to investigate present-day identity formations and changes. They all involve wrestling with a historical dimension that seems hard to bring together with the traditional notion of the goal-rational, linear character of modernity. Koselleck's idea of conceptual crises and intellectual reorientations as results of an increasingly asynchronous relationship between the different partial processes of modernization seems to carry a particular urgency in our time.

\section{Genetic and genealogical perspectives}

Now, let us turn to the second question, why we have difficulties arranging historical consciousness into an analytical framework that might be useful for empirical explorations and teaching purposes. One important answer is that we are still restrained by our traditional scholarly, geneticdevelopmental-chronological understanding of the essence of the historical dimension. If the past has its own intrinsic value, any involvement by posterity is detrimental. History must be explained and understood prospectively and according to the contexts pre-given by the past itself.

However, it seems to me a fruitful procedure to let a reflected historical consciousness include an enlarged, or rather, a double historical perspective. One of them is surely genetic, focusing on the fact that we are and have a history. It goes without saying that a well-designed genetic perspective, especially if it is allowed to lead up to a temporary "now", is instrumental in demonstrating that the individual and society exist in time, having an origin as well as a future. There is an obvious need to relate historical consciousness to an individual's experience of being a part of and an agent in history.

The other perspective is genealogical, maintaining that we make history by reflecting ourselves and our present situation in the past. A genealogical perspective is important to prove that the past is recalled and present in the perceptions, projects and agencies of individuals and society. This means that retrospection is not arbitrary but directed by cultural needs and interest, by historical culture. No doubt, the genetic and the genealogical perspectives may be hard to reconcile. Stormy debates have often been the result when causality contrasts with meaning, prospection with retrospection, distance with proximity, abstraction with concretion, complexion with simplicity, relative validity with absolute validity, reversibility with irreversibility, just to mention a few possible states of 
opposition. In my mind, however, a reflected historical consciousness can balance and join these two fundamental historical perspectives in so far that a genealogical perspective can provide genetic history with agency and criteria of relevance, while a genetic perspective is needed not only to supply us with historical contents, but also to help us understand why history is recalled and represented the way it is. In concert, the two perspectives can demonstrate Kierkegaard's well-known dictum that man lives his life forward but understands it backward.

\section{Processing time}

Another answer to the question why operationalization is a complicated thing is that historical consciousness is a phenomenon without clear determinants. Should it be defined and contextualized from a disciplinary logic, from psychological considerations, or is it worthwhile instead to depart from reflections on its functions in society? Such a socio-cultural analysis, that I will now turn to, must however be preceded by a qualification of the category of historical consciousness. First of all let me say that the "real" character of historical consciousness is a complicated philosophical and epistemological question which cannot be unraveled here. The factors that determine historical consciousness are a combination of qualities and proficiencies acquired by socialization and cultural traditions. Clearly, the degree of historical consciousness, of its strength and sophistication, varies greatly between different collectives and within them, and through time and space. In my mind, it is merely possible to give some very general ideas of the "essence" and working of historical consciousness. For the empirically interested scholar, the concept must obviously be transformed into more comprehensible analytical categories, such as historical culture and uses of history.

It seems reasonable to imagine historical consciousness less as a depository with fixed contents than as an active processor whose function is to help the individual and various collectives to make sense of the contemporary world, in light of experiences and interpretations of the past as well as expectations for and projections of the future. As is indicated by the concept "consciousness", derived from the Latin words con and scentia, approximately "knowing together", historical consciousness is best understood as something that in its fundamental features is shared by others who live under similar external and internal conditions. Thus, historical consciousness often processes notions of belonging and togetherness by helping individuals and collectives go beyond the horizon of their own restricted life spans. 
There is a lot to be said in favor of the idea that historical consciousness does not process cognitive particulars and disconnected facts of the past. Rather, it is connected to a more general awareness of how human beings come to terms with history. However, singular "facts" probably more often than not function to induce us to start thinking historically; for many Hungarians, the mere mention of the word "Trianon" - a castle outside Paris in which on June 4, 1920 a peace treaty was signed that reduced Hungarian territory by three quarters and the Hungarian population by three fifths - is enough to trigger painful notions of a timetranscending character, in the same way that the date "April 24" - the day in 1915 when the Young Turks started slaughtering Armenians in Constantinople - does for Armenians all over the world (Gerner 2007: 79-109, Karlsson 2007: 13-45). This painful, often traumatic aspect is important. Historical consciousness is actively used for the elaboration and qualification of fundamental questions about human life and society. These questions often give rise to reflections on continuity and change, essence and appearance and necessity and contingency which transcend established temporal boundaries. Among them are identity issues of who "we" and who "they" are, existential issues related to life and death, moral problems of what is right and what is wrong, good and evil, and politico-ideological questions related to phenomena such as justice and injustice or power and powerlessness.

To be sure, such "fundamentals" that may serve as crystallizations of historical consciousness can also be found among multi-layered phenomena such as theories, concepts, proverbs, rituals, symbols, comparisons, analogies and metaphors (Heller 1982: 51-71). Jörn Rüsen's wellknown basic position is that the sense-bearing and meaningful character of historical consciousness is best taken care of by means of a logic of historical narration, in which even apparently shocking and contradictory historical phenomena can be induced to make sense in a narrative, constructed from a fabric of temporal experiences and memories with not only cognitive, but also aesthetic and rhetorical building blocks (Rüsen 2005). Consequently, problems not only of identity, but also of fate, crisis and trauma, can probably be expected to evoke a mental activity related to historical consciousness. In fact, in a discussion on how tenacious turning points or "borderline events" such as the Second World War and the Holocaust influence historical thinking, Rüsen has argued that "crisis constitutes historical consciousness, so one can say that there is no historical thinking without crisis" (Rüsen 2001: 253). As briefly indicated above, radical changes, turning-points, contrasts, antagonisms and revaluations in general, and those charged with a high degree of positive or negative values in particular, can probably have the 
same function of stimulating excursions into the temporal realm. All of them obviously have a historical character, because if we have no memory or knowledge of a previous state of things, we cannot characterize a following situation as a break or a change, and simultaneously maintain the context of meaning always inherent in historical consciousness.

\section{Manifestations and activations}

It has already been made clear that historical consciousness in itself leaves no traces that lend themselves to scholarly investigation. Therefore, there is a need for an intermediate level of analytical operation between historical consciousness itself and its effects on the individuals' cognitive maps, attitudes and readiness to take action. The reflections, manifestations and articulations of historical consciousness are best analyzed in historical culture. This may be described as the communicative context in which historical consciousness works and the past is given sense. By means of history-cultural products and activities, individuals and collectives orient themselves on the time axis. Historical culture provides concrete answers to questions concerning what various individuals and collectives find worth preserving, teaching, learning, celebrating and forgetting about the past.

To be sure, the collectives in question are still often national ones. Scholarship has convincingly demonstrated that even history-cultural processes related to non-national dimensions such as world wars or crimes against humanity have normally been handled nationally. Scholarly works are obviously part of historical culture. Nevertheless, the traditional approach of dealing with scholarly products, the history of historiography, is not adequate if we want to stress their relationship to historical consciousness. Some differences are salient. One is that historycultural products must be analyzed not only as effects of prevailing philosophical ideas and scholarly theories, but also as causes to knowledge, conceptions and values of individuals and collectives. In other words, not only the production but also the mediation and the consumption of history must be taken into account within a history-cultural framework. In particular, aspects of the reception of history are seldom addressed by scholars. Existential, moral and politico-ideological motives are often more salient in history-cultural work, and their connection to power relations more explicit. Another methodological difference is that doctoral dissertations and other scholarly products do not normally reflect histor- 
ical consciousness as adequately as broadly mediated history-cultural artifacts such as textbooks, films, and historical fiction.

One way of reflecting historical consciousness is to study its activations or the history-cultural uses of history in society. An analysis of history uses must correspond to those fundamental values of life that previously have been characterized as animating historical consciousness: existence and identity, moral, power politics and ideology. What follows is a typology of different ways of using history, produced in order to reach a more general, comparative understanding of the role of history in society. It is based on theoretical links between different needs of history, different uses, different groups and categories of users, and different functions in society. In addition, these uses are thought to possess different degrees of strength and urgency in different societies and historical periods. Since we will seldom find the types in a "pure" state of realization, the ideal-typical, analytical character of the scheme must be emphasized. $^{3}$

\section{The scholarly-scientific use of history}

The scholarly-scientific use of history is based on strict professional, discipline-specific rules and standards. Criteria of historical relevance are more often than not determined from an internal, scholarly value judgment, which means that the history selected for research or teaching is chosen on the grounds of its ability to illuminate an analytical or a theoretical position considered fruitful to develop, or to give further empirical evidence to a historical phenomenon or setting that already has been the subject of scholarly analysis. To be able to carry out a scholarly-scientific intellectual operation of this kind, professional training is normally considered necessary. Part of this ideal self-perception has been the opinion that it is a scholarly virtue to dissociate oneself from the history interests, needs and requests of the surrounding society. Another part has been a belief in the possibility and the wish to distinctly separate the present from the past. Mediation of history is unproblematic, built on the assumption that the unique, scholarly produced history should be transferred as unmodified as possible from the historians' community to the school and the larger society. Scholarly debates do not normally include references to historical consciousness. If topics such as the Second World War are selected as a relevant issue in history scholarship, the reason is often that "blind spots" of the war should be filled

3 The typology is elaborated from Karlsson 1999. See also Karlsson 2007b: $27-45$. 
with new knowledge, or that interpretations should include other categories than the traditional military ones.

\section{The existential use of history}

The existential use of history is triggered by the experienced need, felt by all individuals to remember or, alternatively to forget, in order to uphold or intensify feelings of orientation, anchorage and identity in a society in a state of insecurity, pressure or sudden change. Memory is a retrospective, present-minded mental process in which we confront or integrate reconstructions or representations of the past, normally images of concrete figures, times and places, with situations in our present lives. Thus, memory can provide the individual with a comforting notion of a connection to or continuity with history, a kind of "presence of the past", which in turn may bring about an understanding that she is part of something larger that her own isolated human life. Consequently, memory, as well as a more fundamental historical consciousness, fosters identity. The existential use of history is often of a very private nature, not transcending the borderline to "large" institutional and publicly mediated history, and not always leaving its imprint in empirical documentation. It should, however, be emphasized that an engagement in what Roy Rosenzweig and David Thelen call the "intimate past", as expressed, for example, in genealogical trees, diaries and photo albums, often leads to a desire to relate to and participate in "larger" pasts situated outside the narrow family worlds (Rosenzweig/Thelen 1998: 115-146). This becomes particularly evident when memories of "traumatic" or "catastrophic" individual experiences such as wars or genocides need to be psychologically digested and culturally made sense of by being integrated into larger narratives (Rüsen 2004: 46ff.).

\section{The moral use of history}

The moral use of history is based on both indignation at the scant attention given to certain aspects of history in a society, and an endeavor to restore or rehabilitate that same history. Generally, the moral use has proved to be prominent in situations where a culturally insensitive government, at the head of a totalitarian or a functionally warped state, is for some reason, such as political-cultural liberalization and newly gained openness, suddenly exposed to criticism because essential aspects of the past have been concealed from the population. Thus, the point of departure of the moral use of history is often a specific event, such as the introduction of a politico-cultural liberalization or change, which often 
manifests itself in the publication of an article, book, or other kind of historical artifact with historical "exposures" or "revelations" that meets with a broad social response and, accordingly, gets a paradigmatic significance. All over Europe, not excluding "bystander" states such as Sweden, several decades of disregard or outright secrecy towards crucial aspects of the Second World War and the Holocaust have aroused strong expressions of "historical" indignation that have had dramatic political consequences everywhere.

\section{An ideological use of history}

An ideological use of history is related to attempts made, mainly by groups of intellectuals and politicians, to gain control of public representations, to arrange historical elements into a dominant context of meaning. This arrangement is not, as in the scholarly-scientific case, defined by its correspondence to empirical evidence and scholarly discourse in general, but by its correspondence to external tasks, or rather by its capacity to convince, influence, rationalize, mobilize and authorize with the aid of historical perspectives. Consequently, the focus on the ideological use of history is not on separate historical elements, as in the case of the moral use, but on the entirety of the historical construct, on its consistency, its pretensions and pedagogical clarity. The ideological use is intimately connected with the success of those systems of ideas that employ history in order to build up legitimacy and rationalize mistakes and errors in the past by referring to objective necessities or historical laws. In general, the objective of legitimation is often reached by means of absolute chronological boundaries and clear-cut periodizations, blackand-white descriptions, strong continuity lines, and perspectives of unproblematic progress. History has proved especially useful for nationalists, whose main interest is to ascertain a special, symbiotic relation between their own nation and a specific territory, on which historical claims are put forward.

Non-use of history, which should be analyzed as a special case of an ideological use, is not a question of simply remembering or forgetting a historical date, or of subconsiously omitting it from a historical context. Rather, the non-use of history is rooted in the deliberate and ideological adoption by some intellectual and political groups of an attitude according to which history, or some part of it, should be ignored. Here, too, reasons connected with the legitimacy of the non-using society or state, or a conscious effort to rationalize historical misdeeds, is involved. Generally speaking, non-use of history is a successful strategy in societies and states where it is strongly felt that legitimacy should not be built on 
history or a cultural heritage, but on the contention that the society in question constitutes a particularly praiseworthy contemporary phenomenon, or on expectations of a rewarding future. A more tangible example of a non-use of history that at present attracts much attention is the denial of the Holocaust or any other genocidal event.

\section{The politico-pedagogical use of history}

The last use of history that I will suggest, a politico-pedagogical one, may be characterized as a deliberate comparative, metaphorical, or symbolic use in which the transfer effect between "then" and "now" is rendered simple and unproblematic, while the scholarly-scientific insistence that history be anchored in the structures of the relevant period is toned down, all in consequence of the main purpose, which amounts to summoning history as an aid in attacking what are felt to be severe and concrete political problems in a later era. A political use of history is particularly hard to reconcile with a traditional scholarly use. And indeed, it is more or less commonplace among historians discussing the use and abuse of history to launch a diatribe against the fact that "historians, or would-be historians, all too often become politicians and generals, shaping and reshaping the historical record to score points, clinch arguments, and advance their own solutions and nostrums" (Dallin 1988: 181). To be sure, the political use of history is a traditional and often-used instrument especially in foreign policy. References to Chamberlain's appeasement of Hitler in Munich in 1938 have attested to the opinion that a "Munich syndrome" has guided foreign-policy decisions long after the advent of the Second World War (Rystad 1982). There are, however, indications that history has been politically used on a broader scale and more frequently in the last full decade, in which the historical dimension has been widely disseminated. In general, the political use of history is related to the contention that the historical dimension is relevant, as offering guidance for political decisions or help in securing political advantages. An effective political use that guarantees the user great massmedial attention relates a political issue at hand to a historical event of strong emotional loading. If a group of anti-abortionists choose to compare abortion with the Holocaust, their intellectual honesty can, for very good reasons, be questioned, but not their political intuition. 


\section{Coda: Is there an abuse of history?}

This discussion finally brings to the fore the problem of where to draw the line between the use and abuse of history. A simplistic solution is to side with a widespread scholarly opinion that the only legitimate use of history is scholarly-scientific, which is guided by rules and standards gradually agreed upon in the course of a protracted professionalization process. In my opinion, it is a highly unsatisfactory position, not least because professional historians no doubt abuse history at least as often as others, by, for example, writing dissertations that no-one outside a limited circle of co-professionals can read and that are devoid of any kind of discussion of criteria of relevance. Do not misunderstand me; professional historical values should not be dismissed. They should, on the contrary, be insisted upon, especially in situations where history is widely used for various purposes in society other than scholarship. However, a scholarly use of history is not the use par préférence, but one of several legitimate ways of furnishing the past with meaning.

But if traditional scholarly considerations are not appropriate for a reasonable distinction between use and abuse, what alternative criteria can be proposed, so that revisionists and deniers with regards to the Holocaust or Soviet Communist terror, or nationalistic history warriors in theatres of war around the world, can be blamed? My only answer, admittedly vague, proceeds from an external, non-scholarly consideration: that uses of history that in themselves or in their consequences violate established principles of human rights, by humiliating, wounding or in other ways inflicting suffering on individuals or collectives, are abuses of history.

\section{References}

Dallin, Alexander (1988): "The Uses and Abuses of Russian History". In: Terry L. Thompson/Richard Sheldon (eds.), Soviet Society and Culture. Essays in Honor of Vera S. Dunham, Westview Press, Boulder \& London, pp. 181-194.

Gerner, Kristian (2007): "Open Wounds? Trianon, the Holocaust and the Hungarian Trauma". In: Conny Mithander/John Sundholm/Maria Holmgren Troy (eds.), Collective Traumas. Memories of War and Conflict in 20th-Century Europe, P.I.E. Lang 2007, Brussels, pp. 79109.

Heller, Agnes (1982): A Theory of History, Routledge \& Kegan Paul, London, Boston \& Henley. 
Jeismann, Karl-Ernst (1979): “Geschichtsbewusstsein”. In: Klaus Bergmann et al. (eds.), Handbuch der Geschichtsdidaktik, Band 1, Pädagogischer Verlag Schwann, Düsseldorf, pp. 42-45.

Karlsson, Klas-Göran (1999): Historia som vapen. Historiebruk och Sovjetunionens upplösning 1985-1995, Stockholm: Natur och Kultur.

Karlsson, Klas-Göran (2007a): "Memory of Mass Murder. The Genocide in Armenian and Non-Armenian Historical Consciousness". In: Conny Mithander/John Sundholm/Maria Holmgren Troy (eds.), Collective Traumas. Memories of War and Conflict in 20th-Century Europe, P.I.E. Lang, Brussels, pp. 13-46.

Karlsson, Klas-Göran (2007b): "Public Uses of History in Contemporary Europe”. In: Harriet Jones/Kjell Östberg/Nico Randeraad (eds.), Contemporary History on Trial. Europe since 1989 and the Role of the Expert Historian, Manchester University Press, Manchester, pp. 27-45.

Koselleck, Reinhart (1985): Futures Past: On the Semantics of Historical Time, MIT Press, Cambridge, MA.

Lukacs, John (1994): Historical Consciousness: The Remembered Past, Transaction Publishers, New Brunswick \& London.

Nietzsche, Friedrich (1983): "On the Uses and Disadvantages of History for Life”. In: Friedrich Nietzsche, Untimely Meditations, Cambridge University Press, Cambridge, pp. 57-124.

Rosenzweig, Roy/Thelen, David (1998): The Presence of the Past. Popular Uses of History in American Life, New York: Columbia University Press 1998

Rüsen, Jörn (1994): Historische Orientierung: Über die Arbeit des Geschichtsbewusstseins, sich in der Zeit zurechtzufinden, Cologne, Böhlau

Rüsen, Jörn (2001): "Holocaust, Memory and Identity Building: Metahistorical Considerations in the Case of (West) Germany". In: Michael Roth/Charles Salas (eds.), Disturbing Remains: Memory, History, and Crisis in the Twentieth Century, The Getty Research institute, Los Angeles, pp. 252-270.

Rüsen, Jörn (2004): "Interpreting the Holocaust: Some Theoretical Issues”. In: Klas-Göran Karlsson/Ulf Zander (eds.), Holocaust Heritage. Inquiries into European Historical Cultures, Sekel, Malmö, pp. 35-62.

Rüsen, Jörn (2005): History: Narration - Interpretation - Orientation, Berghahn Books, New York \& Oxford. 
Rystad, Göran (1982): Prisoners of the Past? The Munich Syndrome and Makers of American Foreign Policy in the Cold War Era, LiberGleerup, Lund.

Samuel, Raphael (1994): Theatres of Memory. Volume I: Past and Present in Contemporary Culture, Verso, London \& New York.

Schorske, Carl (1998): Thinking with History. Explorations in the Passage to Modernism, Princeton University Press, Princeton.

White, Hayden (1985): Tropics of Discourse. Essays in Cultural Criticism, The Johns Hopkins University Press, Baltimore \& London. 



\section{German History Didactics: From Historical Consciousness to Historical Competencies - and Beyond?}

ANDREAS KÖRBER

\section{Competency-orientated history teaching}

In Germany, the results of the PISA-program as well as of a number of other studies before and afterwards (TIMSS, IGLU etc.) have triggered a growing interest in the (measurable) "outcomes" of school teaching. "Educational standards" emerged as the keyword and magic term of the new education debate. Even though there has been no official political program (on the federation-level) to formulate any such standards for history (in contrast to subjects such as mathematics and German) the concept and its underlying principles have influenced the discussion on historical teaching and learning, too. As in some other subjects (e.g. geography, religious education of both Christian confessions), sporadic initiatives either of school administrations of federal states, teachers or academic didacts have worked on "educational standards" for history.

Standards in history should - if developed and agreed upon - take the form of "performance standards", not "content standards" (Körber 2007). This demand conforms to the initial concept of general educational standards (depending on the official political process on the federation level) as outlined in the quite renowned "Klieme-Expertise", named after Eckard Klieme, who presided a committee devising general principles of how to formulate "educational standards". Following their

1 See e.g. Baden-Württemberg 2004 and Verband der Geschichtslehrer Deutschlands 2006. 
line of argumentation, educational standards need to be "domainspecific", i.e. the concept of general "competencies" to be applied to different subject matters has been rejected in favor of a concept of specialized sets of abilities which are used in different fields of knowledge and cognitive activity ("domains") (Klieme et al. 2003). "History" and historical thinking then is one such "domain", besides e.g. geography (orientation in space), languages, sciences etc. and deserves a differentiation of the competencies needed to achieve orientation.

All in all, the concept of "performance standards" based on "competencies" is a useful innovation for history didactics, because it allows for, or rather requires more structural definitions of what earlier had been coined "historical consciousness". By employing the definition of "competencies" by Franz Emanuel Weinert, which is mainly used in the standards debate (including the Klieme-Expertise), it seems possible to differentiate procedural vs. static aspects of historical consciousness as well as cognitive vs. more affective ones.

Weinert defines "competencies" as complexes of (cap)abilities, skills (proficiencies) and dispositions which enable a person to solve (new) problems in a specified domain. ${ }^{3}$

Two of the central characteristics of competencies, following this definition, are that

- they contain knowledge, but that knowledge is not sufficient to speak of a "competence", and

- whatever form of knowledge is part of a "competence" cannot refer to some specific past event, structure etc., because a competence is the mental capability to solve new and different "problems" (of orientation).

Let me give a rough example for the latter: following this concept, it is perfectly possible to attest a high level of historical competence to someone lacking even the most basic information, say, on the medieval German "Old Empire", as long as she/he shows the capability to master a process of coming to terms with this complex through historical thinking. Thus, a professor of history from, say, Japan, in applying himself to

2 The term "knowledge" falls somewhat short here. "Domains of orientation" would be better.

3 Originally, the definition reads: "die bei Individuen verfügbaren oder durch sie erlernbaren kognitiven Fähigkeiten und Fertigkeiten, um bestimmte Probleme zu lösen, sowie die damit verbundenen motivationalen, volitionalen und sozialen Bereitschaften und Fähigkeiten, um die Problemlösungen in variablen Situationen erfolgreich und verantwortungsvoll nutzen zu können“. (Weinert 2001, cited in Klieme et al. 2003: 21). 
the subject matter of medieval Germany, will show a high level in these competencies, even though he will (initially) lack case knowledge.

The form of knowledge contained in historical competencies therefore is structural knowledge, i.e. knowledge on categories and concepts, procedures etc., which needs to be applicable to different historical subjects. Examples of this are systems of periodization, e.g. the well-known differentiation of Antiquity, Middle Ages, Early Modern Times and Modernity vs. the chronology Anno Domini, the differentiation of stylebased epochs of history of art, Jewish chronology, but also other differentiations used in smaller groups, e.g. the reference to "the war" in old people's talk, to the "interwar period", "the postwar era", up to references like "back in the old house" in a family's narrative.

Similarly, second order concepts such as "change" and "evidence" etc. are part of the historical knowledge integrated in the "Sachkompetenz" ("subject matter competence") dimension. This specific competence indicates not only whether a person understands that historical accounts and stories can be "true" or "wrong", but of the concepts used to a) differentiate between these two states and b) to differentiate themselves, too. By which concepts, for instance, does a person express or negate the reliability of a story heard or justify a story to be told?

By drawing on the concept of historical thinking as an individual process of orientation in time, triggered by needs for orientation encountered in "everyday life", I am very skeptical as to the possibility of deriving "educational standards" for the competencies relevant to our domain, i.e. standards as could be operationalized by means of closed items following probabilistic IRT-models. The core argument against standards operationalized like this is that most IRT-models and especially the unidimensional Rasch-model used in almost all large-scaleassessment-programs (TIMSS, PISA etc.) requires items (tasks) which can be coded as either "solved" or "not solved", or at least (with partial credit-technique) as "partly solved", (Rost 2004: 662-678), but that there is no room in this model for differing solutions, which are necessary if historical thinking is to be taken seriously as problem solving from a certain (one's own) perspective (Körber 2008). Therefore, at the moment, work on competencies does not aim at formulating educational standards, but has to appreciate the (underlying) concept of "competence models" as an analytical tool to better define and achieve the goals of historical learning appropriate for post-traditional, pluralistic societies.

At school, learners (pupils and students) must acquire general abilities as well as precise skills and (structural) knowledge, which enable them to take part in the historical and memorial culture of their (pluralist) society. More precisely, they must learn to 
- (correctly) apply concepts and categories, procedures (methods and techniques) commonly used in their society in their own historical thinking,

and to

- have at their command/control these concepts, categories, procedures and methods, i.e. to gain the intellectual and affective distance necessary and the cognitive power to reflect on their benefits and limits, the assumptions inherent in them, their adequacy for a specific problem etc.

\section{A structural competence model}

If historical teaching and learning is neither about teaching "the past" nor about passing on a conventional picture of the past to young members of society (aiming at their integration or assimilation), but about enabling them to individually and critically take part in a society's handling of history, then some more concrete concepts are needed of what this capability can be said to consist of. A model of competence is needed, in order to define

- different fields of historical competence, i.e. dimensions in which the abilities of historical thinking can differ between people, or in which these abilities can differ between different stages of a learningprocess,

- different levels of these competencies, by which any of these differences (between people or between stages of learning) can be "measured".

In Germany, different competence models have been suggested in the last 5 years, ${ }^{4}$ but the model suggested by the FUER group is the only one

- to be based on a specific theory of historical thinking (see below), and

- to introduce both a differentiation of dimensions of historical competence and a concept for distinguishing levels.

4 For a discussion of several models cf. Körber 2007 and Körber 2008. 


\section{Dimensions of historical competence}

The competence-model of FUER ${ }^{5}$ is based on the notion of historical thinking as a process of orientation in time. It distinguishes four basic dimensions of competence, three of which are procedural and one is basic (and rather declarative/static). The three procedural competencedimensions are derived from the circular process of historical thinking, developed on the basis of Rüsen's theory by Hasberg and Körber (2003). From this, the following dimensions of competences can be derived:

- Anyone in need of historical orientation needs the capability to transform her or his perceived uncertainty into some processable form of historical question in order either to reconstruct a historic narrative or to analyze given historical narratives of other people for their historical questions, and to understand them. This first dimension of historical competence ("inquiring competence") spans from the perception of any uncertainty referring to time via the activation of earlier insights, concepts and categories up to the start of a methodically controlled process of re- and de-construction. In fact, it also includes the ability to decide whether (or rather, when) to turn to narrative accounts or to original sources.

- The second dimension of competence ("methodical competence") combines all knowledge and proficiency pertaining to finding and analyzing historical material and to re- and deconstruct historical accounts on their basis. This includes heuristic skills as well as the ability to place pieces of information along a timeline, to draw comparisons between events and structures within an epoch and between historical times and to integrate all this information into a narrative structure, but also to identify the "particles of the past" and the narrative structures in given narratives.

5 A short version (Schreiber et al. 2006); a longer publication includes extensive discussions (Körber et al. 2007). 
Illustration 1: The process model of historical thinking by

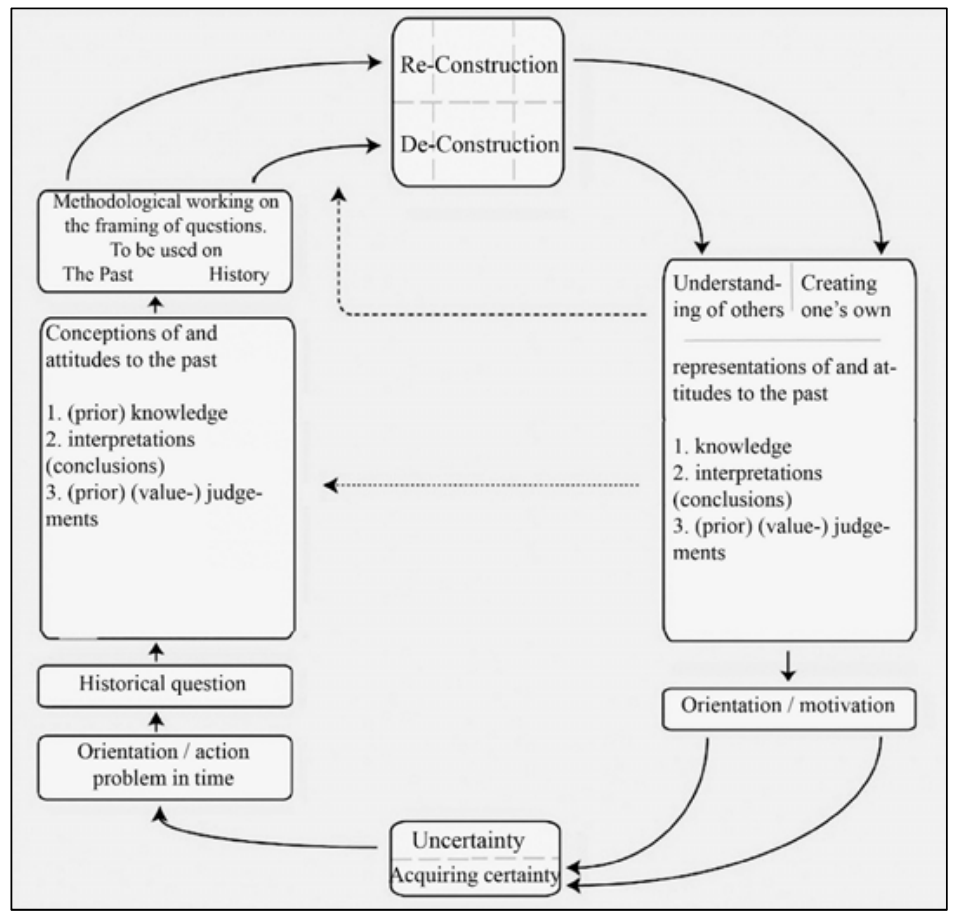

Hasberg/Körber 2003: 187

- The third procedural dimension of competence combines all those often neglected competencies needed for actually using the historical information (previously gathered in processes of re- and deconstruction) for personal or collective orientation in the present and the future. Core competencies in this dimension are

o the ability to revise one's concept of history and the concepts and categories used in historical thinking and one's "historical consciousness",

o the ability (and disposition) to (re-)shape and revise one's own concrete notion(s) of the past and the present world, i.e. one's pictures of other people and/or other times;

○ the ability to (re-)shape the concept of one's self in relation to the outside world and the past, i.e. to revise one's historical identity, e.g. by coming to (new) terms with one's own personal relationship to the deeds (merits and sins) of one's ancestors, etc.

o the ability to (re-)shape the own conceptions of what can be done, achieved, hoped for in the present and the future - in the light of 
the insights and the knowledge derived from analyzing material about the past.

These "procedural competencies" are all linked to a fourth basic (static/declarative) dimension of competence, which is not only needed when executing the process of historical orientation, but also - on the metalevel - in all instances of theoretical reflection and of communication about historical thinking, its assumptions, principles or its results. This fourth dimension of competence has been named "Sachkompetenz" ("subject matter competence") in German, a term otherwise often (but erroneously in our view) used for relating to case knowledge, i.e. knowledge about individual "facts", "dates", "names", but also specific insights etc.

As argued above, such case-knowledge cannot be part of a competence model, because competencies need to be applicable to different situations and contexts. In the FUER model, the term "Sachkompetenz" is used nonetheless, on the grounds that the "subject matter" of historical teaching and learning is not the past, but rather "thinking about the past". Therefore, in our model, this "subject matter competence" stands for the command over/ability to use and apply rather abstract first and second order concepts, categories, knowledge of procedures ad methods etc.

In graph 2 these dimensions of competence are shown as based on the above given theoretical process model of historical thinking. 
Graph 2: The dimensions of competence in the competence model "Historical Thinking” of the FUER-group

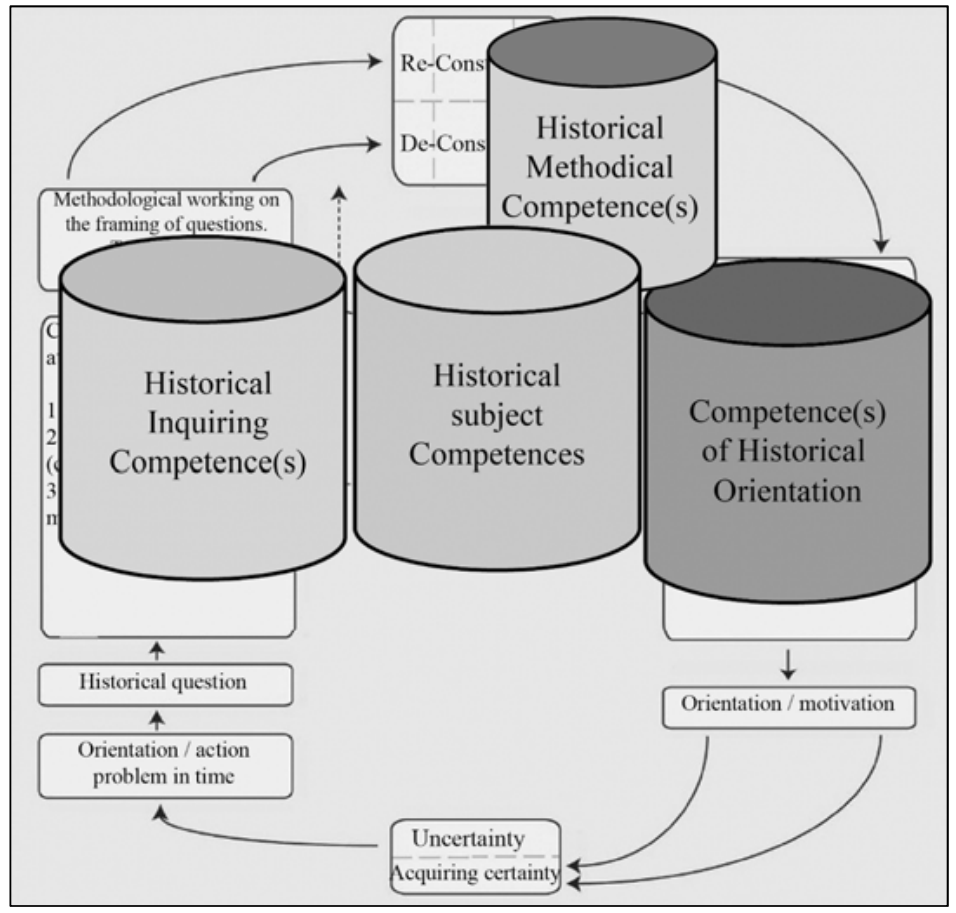

Translated from Schreiber/Körber et al 2003: 56. Translated by the author.

\section{Levels of historical competencies}

As for the differentiation of levels, ${ }^{6}$ our model remotely draws on the widely known concept of Lawrence Kohlberg, referring to the conventional character of moral standards, and distinguishing levels by the relation of moral thinking to these conventions - but with an important difference: we do not (yet) define stages within a process, but levels to begin with. This means that it is not part of our model to postulate some unidirectional development from one level to the next higher one, but that it can also be used to track down and register leaps, "regressions" etc. Thus, in a two-dimensional Cartesian coordinate-system, our levels would constitute the axis of ordinates (y-axis) only with (yet) no claim whatsoever as to a progression with increasing age (or other factors).

6 Within the FUER model, the term "level" is used in order to distinguish from connotations of gradually advancing "stages" or "steps". 
Even though in reality there will be an infinite number of small differentiations of levels, the FUER model only differentiates three, respectively five main levels. The core concept for the differentiation of these levels is the mode and degree of command a person has over conventional forms of applying the operations subsumed under a given dimension of competence:

- On the basic level, a person applies and performs all operations necessary for elementary historical thinking, but without any command over conventional forms, terms, concepts and procedures whatsoever. The person's historical thinking therefore will take on a highly individual and situational form and therefore will not or only hardly be readily understandable to other people, just as the person cannot (or only hardly) use other people's help for her/his own thinking. A (non-historical) example of such a level would be children playing with LEGO-bricks but giving both the building blocks and the assembled constructions new names, so that without some translation or learning they would not be able to order missing bricks in a LEGO-store or to tell anyone what their constructions are meant to represent. An example from the domain of history would be people not familiar with the common concepts of historical periodization, and therefore always referring to "back then" instead of some generally recognized historical time. This basic level, in the FUERterminology, was labeled "a-conventional". Historical consciousness on this level of competence is solitary in nature.

- The intermediate level, accordingly, is labeled "conventional" because it describes the (above mentioned) ability to apply standard terms and concepts, procedures etc. in order to perform one's own historical thinking. This allows for access to all the material and information categorized using these concepts in libraries and archives, enables the person to consult experts and witnesses, but also to communicate the findings and results etc. It is important to note that this intermediate "conventional" level does not require the person to hold conventional beliefs, interpretations and values. It also (or even more so) applies to persons doing their own historical thinking and even disagreeing with their society's consensus, as long as they are capable of using the society's (or other relevant group's) concepts and terminology. Historical consciousness on this level of competence is connective in nature.

- The third level of historical competence then is defined by the ability not only to apply the conventional and standard concepts, terminology, procedures etc., but to reflect upon them, to evaluate them, criticize their shortcomings and (if necessary) to deviate from them, sug- 
gesting new concepts, new terms etc. This level represents an "ideal type" in that it cannot be characterized conclusively: people will never stop learning. As with the "Richter-scale" of seismology, it is open-ended, too. The ideal level has been termed "elaborate" and "trans-conventional" because it requires command over conventions but also the ability to transgress them. Persons on this level could, for instance, be students who have learned that there were times generally referred to as "The Middle Ages" in past reality, but that this concept has been coined retrospectively and has some advantages, but also poses some dangers, ${ }^{7}$ and who are then able to decide autonomously on where and whether to use this concept, and when to resort to/suggest other/better ones. Historical consciousness on this level of competence is reflective in nature.

Let us again refer to the examples used above for the dimension of "Sachkompetenz": A basic level of command over concepts of periodization would be shown if common references to time were not understood. She or he would then have to spontaneously invent new terms, which the others don't know about, and which in most cases would not hold up for other instances. To know these conventional differentiations and to be able to use them when referring to a certain time, also to be able to translate between them in a limited way, would mark an intermediate level. Of course, the ability to translate and recalculate would be higher than mere knowledge, but as long as these differentiations can only be used, but not queried, examined as to their assets and limits, the level would still only be intermediate. Elaborated level then is indicated by insight into the logic by which these periodizations are constructed, by their dependence from cultural viewpoints, and by the ability to reflect upon their appropriateness for a specific task of historical thinking.

As for the second example of concepts to differentiate the reliability of stories, a basic level would e.g. be indicated if a person could just indicate that a story was "doubtful" or "wrong", but would have no idea how to express and justify this judgment using terms others understand. To have in one's arsenal of "Sachkompetenz" concepts like "lying" vs. "telling the "truth", "error" and "misconception", would indicate a (somewhat lower) intermediate level. To be able to refer to concepts of "(multi-)perspectivity", of (different) "interest" and their influence on historical accounts (both in secondary and in primary material), would mark a fully developed intermediate level. An elaborated level could be diagnosed if the person could discuss what "(multi-)perspectivity"

$7 \quad$ See Moos 1999 and Borries 2008. 
means, what the epistemological grounds and implications are, if she or he was able to differentiate between "testimony" and "evidence" and to reflect on further differentiation and new concepts.

In conclusion, Historical Competencies (as formulated in the FUERmodel) offer a more structured version of important aspects of what previously was discussed under the heading of Historical Consciousness. Our model does not abolish or re-invent the entire complex of consciousness concepts, but yields some new opportunities to formulate educational goals (and, less possibly, also standards). It offers the chance to operationalize competencies of historical thinking for empirical research and evaluation, even though only a small part of these competencies will be assessable via quantitative analyses and large-scale analyses as in PISA, and the major part will require qualitative approaches (Körber 2008).

\section{A new concept of historical literacy}

Even though competence-based historical learning and teaching is in no way "knitting without wool" and therefore always will require dealing with concrete aspects of the past, promoting propositional "knowledge about the past" as well as abilities of interpretation and orientation, it is true that the concept reinforces a formal concept of learning. The concern expressed by some teachers and didacts that, as a consequence, the subject matter and historical topics might disappear, must, however, be taken seriously. Still, the solution cannot lie in a model in which the teaching of competencies is accompanied (or even compensated for) by another approach to history-teaching, in which statements about the past are presented as unquestionable truths, as has been suggested by the German History Teachers' Association under the heading of "educational standards". In this Association's own competence model, acquiring competencies of a designated "first dimension of competencies" comes down to memorizing statements of propositional knowledge and judgments the students are only required to "name" and "explain", but not to "consider", "check" or "assess", and the standards listed in the other two dimensions ("competency to interpret and reflect" and "media/method competency"), though focusing on real abilities, are limited to school use (Verband der Geschichtslehrer Deutschlands 2006). ${ }^{8}$ Categorically speaking, such a solution represents a fundamentally conservative strat-

8 See also the discussion between Karl-Heinrich Pohl and Martin Stupperich (the spiritus rector of these standards) in Pohl 2008 and Stupperich 2008. 
egy to the challenges of education, namely the attempt to introduce the young generation to an "existing world of solutions", binding them to their scope (Girmes 1997), instead of enabling them to perform new attempts to find other solutions, better ones, ones more adequate for their times, or even new solutions to new problems.

Renate Girmes, professor in general didactics in Magdeburg, has developed a new concept of literacy ("Bildung"), which, in overcoming the traditional orientation inherent in the classical notion of the term, is more likely to be adequate for post-traditional societies and which is based on Hannah Arendt's anthropological elaboration of the activities (from which Girmes derives "tasks") of human beings existing under certain (given and self-made) conditions. Besides the activities of labour and work, it is a central characteristic of the third main activity, action, that it needs to reflect (and take into account) the plurality of mankind. This state of plurality is not only a quantitative, but also a qualitative characteristic: humans perceive and judge both their historically given conditions and the resulting (individual as well as common) tasks differently, which leads to a multitude of different interests and actions. One of the necessities resulting from this condition is, that people must communicate about their perceptions, beliefs, judgments and actions especially if the society they form is a heterogeneous and posttraditional one - to be democratic. The capacity to tolerate and accept uncertainty and to (actively!) handle it, then, is one of the main tasks of social communication.

However, this kind of uncertainty (resulting from plurality) needs to be distinguished from the concept of contingency in Rüsen's theory of historical thinking. Thus, on the whole, history can be said to be affected by contingency of at least three types (Girmes 1997: 42): ${ }^{9}$

1. The first is contingency that results from temporal experiences of humans when earlier expectations and plans are compared to the eventual, actual (historical) development. "Contingency" here means the mental construct which enables us to conceive the real development not as totally accidental (which would make any effort to construct sense and to orientate oneself futile in the first place) but not as totally determined either (which would deprive us of any possibility to decide about the consequences to be derived from historical insight and therefore of any possibility to $a c t$ ). This form of temporal contingency is the movens of processes of historical thinking / con-

9 For an in-depth analysis of philosophical elaborations and differentiations of chance and contingency and their role in (social) historiography as well as in theory of history see Hoffmann 2005. 
structing meaning. Also, contingency here is part of the explanandum.

2. Another role of contingency in historical thinking is its use as explanans, i.e. the possibility to refer to "chance" in order to construct (reasonable) historical meaning. Strictly speaking, if this were the only strategy, it would prevent the emergence of historical sense in the first place - for referring to chance in historical explanations means not to explain at all. However, it may occasionally be necessary to integrate limited amounts of "chance" into a historical account in order be able to construct an orientating, meaningful narrative. In such cases, "contingency" means to accept "blind spots" in history which are resistant to explanatory efforts and to which to resort to does not (or only rarely) constitute a surrender. Often, contingency is used in this way not so much to refer to coincidence in history, but as a means of either masking a thread of inquiry not further pursued by the narrative's author or marking a change of perspective. This is e.g. the case when references are made to events which "by chance" foil a strand of action, events, which could neither have been influenced nor foreseen by the actors in the resulting history, but could be clarified by further inquiry on another scale. ${ }^{10}$

3. The third version of contingency, which is central here, is to be found on the side of the results of historical thinking: due to their multi-dimensional plurality, humans exhibit different needs for temporal orientation. Because of the different times, societies, social groups, cultures etc. they live in, they will quite naturally be using different concepts, operations, patterns of explanation and of narrating which in turn will result in different narratives. These narratives / constructions of meaning will not be incomparable, but also not simply translatable into one another. In that sense, it is historical orientation itself which is contingent - contingent not only in its temporal, but in cultural, spatial and social dimensions. And as for people living and acting within the plurality of today's societies, it becomes vitally important to (be able to) handle this contingency of narrative orientations.

10 An example would e.g. be a narrative portraying the success story of a company suddenly destroyed by a terrorist attack which "by chance" took place at the very moment of the signing of an important contract. Although both actions, the signing of the contract and the terrorist attack, are by no means accidental in themselves, their actors and motives are totally unconnected unless a connection is discerned or established by focusing another level (e.g. the terrorists' view of the economic system and the company's role within this system). 
What is more, each of the latter contingent orientations (3) is not only a narrative, but constitutes a world, a perception of (temporal) reality guiding the actions of its bearers. Thus, alternative narratives among individuals and cultural groups ultimately represent different "solutions" to the task of temporal orientation.

In this sense, in the plural societies of a globalized world, it becomes increasingly important not only to participate in the construction of historical sense and of political rooms in which to communicate, but to gain insight into the perceptions of (the task as well as) the results of other people's thinking.

It is here that we find the basis of a new concept of historical literacy. From this point of view, literacy is neither to be defined as some high-class knowledge about important events and actions in the past nor as a set of general insights into the historicity of mankind, even though this latter aspect can still be part of the concept, as the Swiss philosopher Peter Bieri recently pointed out in a lecture entitled "What would it be to be literate?". As to the religious dimension, he formulates: "Only he who knows about and acknowledges the historical contingency of his cultural and moral identity really has grown up." (Bieri 2005: 4) ${ }^{11}$ In this quotation, the classical notion and concept of German literacy lingers on in a familiar way. But the sentence is framed by statements which add another relevant aspect, more reminiscent of what has been said about the importance of contingency so far:

"The knowledge of alternatives only seemingly deprives it [here: religion] of its value: the value can even be experienced as higher, because we now no longer deal with an intangible fate, but with free choice. [...] One has not completely taken over the responsibility for one's own life, as long as one accepts an external authority prescribing how to think about love and death, morality and happiness." (Bieri 2005: 4)

Similarly, Girmes proposes as a quality for being able to deal with uncertainty in post-traditional societies, not to look for certainty, but to (learn to) think in concrete constellations. Education aiming at literacy therefore should neither aim at providing the learners with fixed solutions (here: fixed narratives) nor with tasks and tools to find such solutions only, but also with the variety and plurality of different real and possible solutions as a prerequisite for thinking and living in a new and self-determined way (Girmes 1997: 44).

The multitude of different narrative orientations therefore is not only be to be used as an exchangeable substrate for developing formal com-

11 All translations are by the author unless otherwise indicated. 
petencies (especially that of de-constructing other people's orientations and narratives), but gains a value in itself: these narratives (which still need to be de-constructed and analyzed as well as critically reflected as to their plausibility) are both the repository of concepts, patterns of interpretation and explanation, values etc. for later use, and they also represent the variety and plurality of life-guiding orientation of a person's fellow citizens. "Historical literacy" therefore is rooted in knowing about this multitude and variety, in being familiar with great parts of these orientations, in accepting and assessing their orientational function and strength and in recognizing the necessity and the value of this multitude of orientations in itself.

\section{Consequences for didactics of history}

It is not easy to derive clear-cut consequences from principles and models which are still under debate. The following therefore is more or less to be understood as suggestions and impulses for the current discussion. For history didactics as a discipline, the orientation towards competencies calls for a more consequent definition of its own theoretical basis and its self-concept. Neither the work of academic historical research nor mere political and/or pedagogical aims can be at the heart of its reflections, but original theoretical reflections on what history is and what it is for. History didactics in this sense is a meta-discipline which embraces the work of academic research as one, if particularly important, instance of the many forms and institutions of historical thinking, but its aim is not to steer this academic work or to externally set standards for it, but rather to reflect its position and relevance for society.

As for future research, first of all, the empirical validity of the FUER-competence model needs to be tested (Are the distinguished dimensions discernible in data? Can different levels, as postulated, be found as a matter of fact?), and, as a second step, research needs to be conducted as to the identification of developmental processes. It might be that learning historical thinking comes down to a mere (steady) increase in the levels in all dimensions and competencies, but it is also possible, that differences in pace of development, phases and ties between levels among/within different competencies or even regressions can occur.

Furthermore, the theoretical premise that historical thinking occurs on all levels and that the intermediate level is marked by command over conventional concepts, whereas the elaborate level is marked by the ability to reflect, criticize and change conventional categories, calls for 
empirical analyses into specific conventional concepts, procedures etc. of specific groups of society and for comparisons of their standards of historical orientation. For a type of history teaching which does not aim at transmitting specific interpretations into the students' heads, but at enabling students to handle different perspectives, questions and concepts, this would prove essential.

Last but not least, models, strategies and instruments are needed for determining levels of historical competence(s) underlying actual forms of historical performance. These are needed for large-scale assessment and evaluation purposes, but even more for individual diagnostics and subsequent educational measures in school. A lot of work remains to be done in this respect, especially since the instruments used e.g. in PISA can (in my view) hardly be applied to the domain of historical thinking (Körber 2008).

\section{Consequences for history teaching}

\section{Consequences for history teaching in general}

The first and most obvious consequence of the sketched understanding of historical learning is that history teaching at school must be about promoting students' historical competencies. In the broad sense of the term "competence", this, at first, does not seem to amount to something fundamentally new. Teaching only specific knowledge and authoritative interpretations of the past seems to be a bygone concept anyway. But a closer look at current suggestions for curricula (some actually in force by now) shows that even under the heading of "orientation towards competencies", in some federal states and by some actors in the debate, exactly this is promoted, when, for instance, in the German History Teachers Association's concept, students' abilities are narrowed down to "naming" specific aspects, to "explaining" events, structures, actions in specific pre-determined ways and students are even required to come to specific conclusions, such as presenting the crusades as a "conflict, but also as a chance for (cultural) encounters between the Christian and the Muslim world." 12 Other crucial abilities (more likely to deserve the term "competencies") are also included but are only illustrated by examples of minor controversies and, revealingly, never by examples questioning the Eurocentric grand narrative presented (as factual) in the first place.

12 The example is taken from the German History Teachers' Association's (suggestion for) "educational standards" (Verband 2006). For a critique see e.g. Körber 2007. 
Furthermore, these abilities, too (analyzing material, considering multiple perspectives etc.) more closely resemble techniques rather than methods of independent historical thinking.

As is becoming clear, the consequence to focus history teaching on developing competencies and dispositions needed for independent participation in a society's historical culture and debate is not so selfevident as it would seem.

Moreover, our model of historical competencies calls for paying attention not only to techniques and methods as well as concepts, terminology etc. (competence-dimensions "methodical competence" and "subject matter competence"), but also explicitly for developing the abilities to ask historical questions ("inquiring competence") and to (individually and collectively) reflect upon possible consequences of specific stories (which have been derived from re- and/or de-constructive processes) for the present, the future and for further thinking. Together with the de-constructive component of "methodical competence" this also demands the use of historical narrations not only (or even mainly) as media of bits and pieces of information, but as material to be analyzed in depth. Students and pupils must learn to dissect the narrative structure of historical accounts in order to be able to consciously and critically handle them.

Last, but not least, as follows from much of what has been said earlier, the conventional concepts a society uses for grasping and structuring the domain of history and historical knowledge should be presented not as factual, but have to be addressed explicitly and in a reflective way. Thus, for instance, the common concepts of periodization (Antiquity, Middle Ages, Modernity) need to be taught as contingent models with specific benefits and limits, which need to be compared to others (e.g. of history of art, of ecclesiastical history and of course to the ones used in other cultures as in Islam and such used in everyday life). ${ }^{13}$ The same holds true for (other) conventions of historical methodology such as procedures of analyzing material, of story telling etc.

13 See. v. Borries 2008. 


\section{Teaching in a controversial memorial culture}

As for the subject of this book, the competence orientation and competence model holds some further consequences for history teaching. Most notably, competence orientation calls for an integration of the large field of commemoration and memory culture into history teaching at school. The old dichotomy of "history vs. memory" which has been stressed by Halbwachs and still by the earlier Jan Assmann should not lead to excluding the "family album" and "public memorial culture" - type of addressing the past (and orientation) from the curricula, which would result in the denial of their power, logic and relevance by pointing to the academic dignity of scientific knowledge. Quite contrarily, these specific functions, their conditions and the immanent logic of communicative, social and cultural memories (A. Assmann) need to be explicitly addressed and recognized. On the other hand, it would also be wrong to treat these as sacrosanct and as not revisable in the light of other, most importantly, academic knowledge. For prospective members of a pluralist society, it is of utmost importance to be able to reflect upon the respective status and benefits, but also the limits of specific forms of (historical) construction of meaning.

This then, among other things, means that students must learn to reflect upon the epistemological status of original sources as well as upon that of contemporary witnesses, that they must become acquainted with the concepts of "authenticity", "originality" and "truth", as well as with those used in memory debates like "victim" and "sacrifice", the differentiation between different types of memorials (hero-, victim- and so on), the political concepts which draw on historical interpretations (like "hierarchy of victims" vs. "equalization of victims") and so on.

History teaching needs to address the plurality and multiplicity of handlings of the past and of orientations drawn from history, it must enable students to recognize the interests of specific groups in history, their questions, their political agenda, but it must enable them to arrive at conclusions and judgments individually and independently, too. History teaching in this sense is not about forming a society by creating uniformity, but about forming social coherence ${ }^{14}$ by enabling people to handle multiplicity and diversity through responsible reasoning.

14 I here relate to a distinction within a new concept of "interculturality" by Klaus-Peter Hansen. See Rathje 2006. 


\section{References}

Baden-Württemberg (2004): "Bildungsstandards für Geschichte Gymnasium - Klassen 6, 8, 10, Kursstufe". In: Baden-Württemberg (2004): Bildungsplan Gymnasium. Stuttgart, pp. 215-232, also available on http://www.bildung-staerkt-menschen.de/service/downloads/ Bildungsstandards/Gym/Gym_G_bs.pdf.

Bieri, Peter (2005): 'Wie wäre es, gebildet zu sein?' Festrede von Peter Bieri an der Pädagogischen Hochschule Bern über Bildung vom 4. November 2005. http://www.phbern.ch/fileadmin/Bilder_und_Doku mente/01_PHBern/PDF/051104_Festrede_P._Bieri.pdf (read 3/612009).

Borries, Bodo v. (2008): "Epochenkonvention und Epochenreflexion Ein geschichtsdidaktischer Essay.” In: Zeitschrift für Geschichtsdidaktik 7, pp. 114-121.

Girmes, Renate (1997): Sich zeigen und die Welt zeigen. Bildung und Erziehung in posttraditionalen Gesellschaften, Leske\&Budrich, Opladen.

Hasberg, Wolfgang/Körber, Andreas (2003): "Geschichtsbewusstsein dynamisch.” In: Andreas Körber (ed.), Geschichte - Leben - Lernen. Bodo von Borries zum 60. Geburtstag, Forum Historisches Lernen, Wochenschau Verlag, Schwalbach/Ts, pp. 179-203.

Hoffmann, Arnd (2005): Zufall und Kontingenz in der Geschichtstheorie. Mit zwei Studien zu Theorie und Praxis der Sozialgeschichte (Studien zur europäischen Rechtsgeschichte; 184), Klostermann, Frankfurt am Main.

Klieme, Eckhard/Avenarius, Hermann; Blum, Werner et al. (2003): Zur Entwicklung nationaler Bildungsstandards: eine Expertise. Bonn: BMBF Online: http://www.bmbf.de/pub/zur_entwicklung_nationaler _bildungsstandards.pdf (read 29.12.2005).

Körber, Andreas (2007): "Eine Kompetenz zum 'Durcharbeiten' der Geschichte? Eine Anfrage an Peter Schulz-Hageleit.” In: Judith Martin/Christoph Hamann, (eds.), Geschichte - Friedensgeschichte Lebensgeschichte. Festschrift für Peter Schulz-Hageleit, Centaurus, Herbolzheim, pp. 9-30.

Körber, Andreas (2008): "Sind Kompetenzen historischen Denkens messbar?" In: Volker Frederking (ed.), Schwer messbare Kompetenzen. Herausforderungen empirischer Fachdidaktik und unterrichtlicher Praxis, Schneider Verlag, Baltmannsweiler, pp. 65-84.

Körber, Andreas/Schreiber, Waltraud/Schöner, Alexander (eds.) (2007): Kompetenzen Historischen Denkens. Ein Strukturmodell als Beitrag zur Kompetenzorientierung in der Geschichtsdidaktik. 1st Ed. 
(Kompetenzen: Grundlagen - Entwicklung - Förderung; 2), ars una, Neuried.

Moos, Peter v. (1999): "Gefahren des Mittelalterbegriffs. Diagnostische und präventive Aspekte." In: Joachim Heinzle (ed.), Modernes Mittelalter. Neue Bilder einer populären Epoche, Insel-Verl. (Insel Taschenbuch; 2513), Leipzig, pp. 31-63.

Moos, Peter v. (2007): Wie mittelalterlich war das Mittelalter? Theoretische Essays zur Mediävistik und Mittelalterrezeption (Geschichte: Forschung und Wissenschaft; 26), LIT Verlag, Münster.

Pohl, Karl Heinrich (2008): "Bildungsstandards im Fach Geschichte. Kritische Überlegungen zum Modellentwurf des Verbandes der Geschichtslehrer Deutschlands (VGD)." In: Geschichte in Wissenschaft und Unterricht 59; 11, pp. 647-652.

Rathje, Stefanie (2006): Interkulturelle Kompetenz - Zustand und Zukunft eines umstrittenen Konzepts. Jena: Universität, Fachgebiet IWK Online: http://www2.uni-jena.de/philosophie/iwk/publikatio nen/interkulturelle_kompetenz_rathje.pdf (read 2.2.2008).

Rost, Jürgen (2004): "Psychometrische Modelle zur Überprüfung von Bildungsstandards anhand von Kompetenzmodellen”. In: Zeitschrift für Pädagogik 50; 5, pp. 662-678.

Schreiber, Waltraud/Körber, Andreas/Borries, Bodo v. et al. (2006): Historisches Denken. Ein Kompetenz-Strukturmodell (Kompetenzen: Grundlagen - Entwicklung - Förderung; 1), ars una, Neuried. 64 pages, can be found online <http://www-edit.ku-eichstaett.de/Fakultaeten-/GGF/fachgebiete/Geschichte/DidGesch/publikationen/f_/Sonderdruck_Kompetenzen_2Auflage.pdf $>$.

Stupperich, Martin (2008): "Der Modellentwurf Bildungsstandards des Verbandes der Geschichtslehrer Deutschlands. Eine Antwort auf die Thesen von Karl Heinrich Pohl”. In: Geschichte in Wissenschaft und Unterricht 59; 11, pp. 653-661.

Verband der Geschichtslehrer Deutschlands (2006): Bildungsstandards Geschichte. Rahmenmodell Gymnasium 5.-10. Jahrgangsstufe (Studien des Verbandes der Geschichtslehrer Deutschlands), Wochenschau-Verlag, Schwalbach/Ts. 


\title{
Coping with Burdening History ${ }^{1}$
}

\author{
BODO VON BORRIES
}

\section{Types of coming to terms with historical harm and guilt}

\subsection{Outline of the argumentation}

History is only learnt effectively under three given conditions: if new insights can be linked up with old ones, if it is connected to - negative or positive - emotions and if it is relevant in life. The learning of affirmative cases of heroism and glory/pride seems easier, but burdening experiences of harm and guilt/shame (or both of them) are much more difficult. The Holocaust and the other mass crimes of National Socialism are good examples. It is quite clear that learning means more than scientific investigation, it includes a mental conflict as well as change: Coping with burdening history is a problem of mental working through as well as of intellectual activities. There are productive forms of coping with burdening history and defective ones. Four of these defective forms will be analyzed below (see section 1.3.): ${ }^{2}$

a. Hostile histories in a revenge and blood-feud system (inherited enmity),

1 This text is to a large extent identical with the second half of a presentation given at the conference "Opening Historical Reconciliation in East Asia through Historical Dialogue" in Seoul in October 2007, meanwhile published (Borries 2009).

2 The typology presented here was introduced by myself some years ago (see Borries 2008: 121-137). It is the result of theoretical reflections as well as of observations and qualitative empirical studies in the culture of history (autobiographies, novels, interviews, historical narrations). 
b. The history of the winners and damnation/oblivion of the losers (cynicism of power),

c. The underground history of losers and hope for inversion (heroism of remembrance),

d. Lost hostile history discarded due to irrelevance (priority of surviving).

In parts, these mental reactions may be inevitable. Achieving a real reconciliation however - with former enemies (victims, perpetrators) and with yourself - is more complex (see section 1.4.). People need the experience of moving towards each other and continuing together along the same path (in life and historiography). But this involves - besides undoubtedly necessary analyses of historical events and interpretations according to intellectual standards - a process of taking distance from one's own past and that of the other without forgetting one's history. The aim is to search for the conditions and chances of a common future (in spite of a hostile history). Some examples will serve to illustrate this.

Afterwards, some German experiences with different strategies of reflecting and (self-)reflective methods of learning history ${ }^{3}$ for promoting reconciliation via history are discussed (see section 2.1 to 2.4.).

\subsection{Some reflections about the feelings of guilt and shame in respect to history}

A remark about terminological - and systematic - issues is necessary. What is "burdening history"? Does it include guilt like grief and harm? Are there any examples of collective or inherited guilt? Or is this an inadequate notion? Of course, different ways of expressing and developing central categories are possible, but they must be logically clear and morally convincing.

Guilt can only be personal in the strict sense of penal courts. A punishment of another family member, another hostage from the same profession, city or nation is a clear violation of international law and human rights. ${ }^{4}$ Any assignment of guilt to innocent and uninvolved persons or later generations is an unjust, illogical, archaic reaction in itself. For people born after 1945 any collective guilt in the context of National Socialism can only be a metaphor, and a dangerous one. This does not mean any denial of guilt by default (or omission) among many contem-

3 In respect to the theoretical foundations, please compare the contribution of Andreas Körber in this volume.

4 The NS state often oppressed - or punished - completely un-involved relatives of opponents ("Sippenhaft"); this was one of the Nazi-crimes. 
porary German bystanders, but this is individual guilt, not a collective one ${ }^{5}$.

That does not imply that members of later generations born in a country where political crimes against mankind (e.g. genocides) have been committed are completely disconnected from any special relation to the past, or are not involved any differently than anyone else in the world. Countries - we should better say: societies - have their unspoken continuities, self-evident truths, socially desired answers and traditions, transferred by socialization (like a heritage). Even if nobody can inherit guilt for a crime, he or she can inherit the consequences and costs of a crime. Of course, the benefits of past crimes (at least of the last decades) have to be returned - and the damages recompensated as far as possible. This is often called responsibility. The notion makes sense if understood correctly. ${ }^{6}$ Nevertheless, the word liability should be preferred, since responsibility often includes guilt (for instance, if a captain is responsible for the sinking of his ship). German citizens remain collectively liable for a lot of costs and problems, even in the innocent third and forth generations and even if they are innocent (grand-)sons and (grand-) daughters of immigrants from Turkey or Russia.

Shame is a third problem. A son of a man who murdered his wife and buried her in the garden is not guilty, but he may feel very ashamed and burdened for the rest of his life. This is the case of succeeding generations in Germany (and perhaps other countries like Russia or Japan). Shame is a very strong and uncomfortable feeling. Therefore the temptation to escape shame via denial/refusal of the crime is also strong. Many reactions can only be understood as avoidance of shame. Forcing someone to be ashamed is an offensive act, often answered by aggression. Nietzsche famously wrote "'I have done that', says my memory. 'I cannot have done that', says my pride, and remains adamant. At last memory yields." (Nietzsche 1968: 86) Coping with shame - without denial or depression - is very difficult; it includes admittance and distance at the same time.

Fourthly, the decisive feeling in the case of burdening history is - or should be - mourning (Liebsch/Rüsen 2001). But what is mourning? In private life, we associate it with pity - and also self-pity. Mourning is coping with a loss, with a hole in one's life, with the hurting absence of a beloved person or relation. Psychoanalysis experts refer to mourning

5 For an empirical analysis on the theme of victim and guilty in the case of Finland see the contribution by Ahonen in this volume.

6 The clear allusion to the character of an answer, a reply to a demand from outside (in English like in German) is an additional advantage of the term "responsibility" (see Jonas 1984, 1987). 
as work, thus working through history, work of commemoration, and work of mourning become very similar. The emotion - while learning to live with a loss - is a mixture of pity with the unhappy, ill or dead person and of self-pity because of having lost a relative or a friend, simply because of being bereaved, perhaps lonely. In the case of mental burdens from history, we seriously have to ask which elements constitute the feeling of mourning. After the Holocaust for instance, who are the young Germans of 2010 mourning for, if they mourn: The murdered Jews and Slavs - or the lost honor, innocence, self-esteem, and territory of their great-grandfathers? Who do they mourn together with?

Thus the mental task of coming to terms with burdening history (in the sense of severe crimes committed by one's own side in the past) - in a country, a family or an institution - is rather complicated, protracted and mentally burdening. A productive solution includes the admittance of the crimes committed; the handling and reflecting - and avoidance of temptations to deny or forget; the rejection of any personal guilt, while distancing oneself from the perpetrators and acknowledging liability; coping with feelings of shame and even more so with expectations or demands to feel shame expressed or made by others. For young generations in societies that have continuity with periods of major crimes, this does not imply simply internalizing the history as told by grandparents, parents, authorities and the state. Instead, they have to reflect, study, compare, examine, and decide for themselves when dealing with historical interpretations and their own orientation. Therefore, the common sentence "Grandpa was no Nazi!" - frequently used by young Germans - (Welzer et al. 2002) may often be wrong, but the sentence "Don't confuse me with my grandpa!" is morally correct.

\subsection{Defective forms of working through history}

Learning or grasping history is not a cognitive process alone, but also a question of emotions, aesthetics and moral judgments. To secure and connect certain little pieces of the past (some call them facts) may be important, but is not enough. The question is, how to give a general, valid, and agreeable version of the historical narrative and how to handle the effects for the present. The mental act of assimilating, digesting and overcoming burdening histories is decisive. ${ }^{7}$ Of course, the process of

7 For systematic and pragmatic reasons, the extreme case of "Holocaust Education" cannot be analyzed in detail here, but I have written some articles about it during the last years (see Borries 2004a/b, 2005, 2006a/b). Twenty years ago, any comparison of the Holocaust with other genocides and mass crimes (like those committed by the Japanese war in China) was 
working through - to use a psychoanalytical notion - can, in a controversial case, take diametrically opposite directions.

The grandchildren of victors and defeated, of perpetrators and victims, of rich and poor may remember and digest a certain event or development in rather contrasting ways. ${ }^{8}$ In addition to the technical process of writing history, the mental (social psychological) conditions for dealing with terrible experiences are the decisive point. Obviously, the processes follow certain patterns. When human beings use history in their lives and for their legitimations and decisions, i.e. when they orient themselves by means of history to confront and face the future (see Rüsen 1994a), ${ }^{9}$ they choose a limited set of strategies and logical versions. ${ }^{10}$ To know them is a vital precondition for the description and analysis of chances and risks for reconciliation (comp. Borries 2004b, 2008, p.121-137).

1. If both sides only wait - and prepare - for the next clash after the end of a preceding war, the situation is clear but dangerous. Rome and Carthage fought such wars in the third and second centuries B.C. Peace was only a pause to gather new assets, i.e. weapons, troops, money and allies. The old wars had to be re-enacted in new campaigns until the complete destruction of Carthage. The situation between Rome and Persia in late antiquity was similar - up to the decisive victory of the Arabs against both Rome and Persia. The repetition of serious wars between

considered taboo. Today one could be criticized for omitting "Holocaust Education" in an analysis of "historical reconciliation". It is just the opposite. For me, the case is much more complicated, and therefore it cannot be covered explicitly here.

8 A remark about perpetrators and victims has to be added here. A perpetrator may, indeed, later on become a victim. Psychologically, it is not wise and fair to accuse the (former!) aggressors and their heirs of remaining fixed in their view when engaging in a discourse about harm and mourning within their own society. Of course, proportion and causation have to be taken into account.

9 According to Rüsen (1994 and often), orientation for the present and the future is the basic purpose of history.

10 Rüsen's theory of the logical patterns of making sense out of history (1994a and often) is a very basic and important one, since it clarifies different modes of relating past and present/future, i.e. of concluding from history for the sake of a current orientation. "Traditional" sense-making means the prolongation of an institution or value invented in the past and remaining valid for the future. "Exemplary" sense-making is subsuming a historical event/structure as a case under permanent and lasting rules (e.g. pragmatic historiography). "Critical" sense-making includes an autonomous decision against a societal interpretation of history, e.g. the denial of an outdated tradition or a false (inapplicable) rule. "Genetic" sensemaking accepts the change of rules in the course of time (development) also, but insists on continuities, on duration in change. 
Sweden and Denmark or Sweden and Poland may also have been a main reason for the common decline of both enemy partners. These are the typical outcomes of such assimilations of history: total defeat and annihilation of one side or common decline of both sides caused by a third power from outside. This type of reaction may be called "revenge system" or "blood feud" with the character of a vicious circle - the opposite of historical reconciliation.

2. Another type is the "winner's history": If one party has really won, it can decide about memories, perhaps for a very long time. ${ }^{11} \mathrm{We}$ know a lot of cases where the victor destroyed the documents, memorials, memories, and leading families of the defeated (though not the whole population). Thus Shi Huang Ti, the first emperor of imperial China, is said to have burned all historical books of the other dynasties (except his own Chin) and of the other philosophical schools (except his own "legalism"). The question whether he really did so, is less important than the idea and structure as such. The story was taken for granted for more than 1500 years. Other victors acted alike, e.g. the Fulbe against the Haussa in Western Africa, the Spanish against the Maya in Yucatan and Christians against "heathens" in Central and Eastern Europe. The destruction of buildings, statues, paintings and monuments may be added to the burning of texts. This "damnatio memoriae" ([con]damnation of memories) can be a successful strategy in the long - or very long run; perhaps the population may forget its ancestors or its descent. Nevertheless, this complete "oblivion" and "loss" is also far from "reconciliation". It may be called "cultural - not physical - destruction".

3. But it is not easy to completely destroy the traditions of defeated collectives. Mothers may tell their children, itinerant priests their believers. Oral traditions can be saved for centuries; they can be preserved and spread separately from the official histories of the ruling group (in schools or chronicles). This is "underground history" in slave language and only carries validity for the subjugated, but also for small ethnic groups in large European empires (Ireland, Basque region, Estonia, Slovenia, Czechia). ${ }^{12}$ The case of Latin America is perhaps even more interesting. Of course, Spanish and Portuguese conquerors tried to force their victors' histories on the native Americans ("Red Indians"). But very often, the official, written, so-called scientific version is counteracted and devalued by oral variants of pre-modern, mythical character

11 "History is written by the victors, at least by the survivors, at worst by the slayers."

12 If the one-sided history versions of the winners (the large empires) had been successful in all European cases, we would not have around forty but only around ten or fifteen European states. 
among the "aborigines", in particular when they live far from the big cities in remote areas and speak their pre-Spanish and pre-Portuguese languages. Thus, the old gods, old kings, old heroes, and old myths are surviving - and with it the hope for a future post-Spanish (or postPortuguese) "golden and happy era". Such "underground history" may guarantee cultural diversity and richness, but it is definitely no historical reconciliation.

4. On the other hand, the battles, hardships and crimes of the past between two groups can also fade away, even if no winners command and rule the losers. Progress of time and change of (economical, cultural, technological) conditions may simply overrun and devalue the heroes and hatreds of the past. In Italy, the parties of Guelphs and Guibellines faught, killed and executed each other in nearly all cities for a period of two hundred years (like the already mentioned "blood feud"). But some generations later it became difficult to understand - or internalize - the reasons of this existential struggle. Maybe, the relation of the two big Christian confessions in Germany is an even better example. Catholics and Protestants fought each other for a long time, not only in the Thirty years war (1618-1648). All over Europe, martyrs were executed and minorities were persecuted (religious cleansing); authorities forced their subjects to convert and robbed them of all their rights and property. In the end, formal tolerance was laid down in the "Holy Roman Empire of the German Nation". The rivalry and mistrust, however, lasted much longer (they tolerated, but strongly disliked each other), maybe even until 1948. Today, only sixty years later, many - at least some - children do not know, whether they are Catholic or Protestant (or neither). There are a lot of mixed couples. The history of the religious split has become irrelevant, and the attitudes towards it indifferent, apathetic. Can this process be called historical reconciliation? I doubt it, because I prefer the notion a-historical, anti-historical, a falling asleep or a dwindling away of a conflict. The past does not only loose its power over the present (which is necessary and acceptable in some respect), but also its dignity and relevance (and perhaps that constitutes a problem).

These four types of "historical non-reconciliation" form a system of oppositions and similarities: 
Table 1: Types of Missing Historical Reconciliation

\begin{tabular}{|l|l|l|l|}
\hline $\begin{array}{l}\text { Integration of } \\
\text { histories } \\
\text { Direction and } \\
\text { perspectives }\end{array}$ & $\begin{array}{l}\text { Attempts to create } \\
\text { common memories, } \\
\text { assured peace with- } \\
\text { out historical recon- } \\
\text { ciliation. }\end{array}$ & $\longleftrightarrow$ & $\begin{array}{l}\text { Preservation of sepa- } \\
\text { rate memories, threat- } \\
\text { ening war due to lack } \\
\text { of historical reconcili- } \\
\text { ation. }\end{array}$ \\
\hline $\begin{array}{l}\text { Mainly seen from } \\
\text { the viewpoint of } \\
\text { the ruling institu- } \\
\text { tions (history poli- } \\
\text { cy top down) }\end{array}$ & $\begin{array}{l}\text { Winner's history and } \\
\text { loser's damna- } \\
\text { tion/oblivion (cyni- } \\
\text { cism of power) }\end{array}$ & $\longleftarrow$ & $\begin{array}{l}\text { Hostile histories in a } \\
\text { revenge and blood } \\
\text { feud system (inherited } \\
\text { enmity) }\end{array}$ \\
\hline $\begin{array}{l}\text { Mainly seen from } \\
\text { the viewpoint of } \\
\text { populations (histo- } \\
\text { ry policy bottom } \\
\text { up })\end{array}$ & $\begin{array}{l}\text { Lost hostile history } \\
\text { dwindled away due } \\
\text { to irrelevance (prior- } \\
\text { ity of surviving) }\end{array}$ & $\longleftarrow$ & $\begin{array}{l}\text { Loser's underground } \\
\text { history and hope of } \\
\text { inversion (heroism of } \\
\text { remembrance) }\end{array}$ \\
\hline
\end{tabular}

\subsection{Strategies of historical reconciliation}

If all these ways are misleading, what are the chances and structures of succeeding in reconciliation? Of course, there are political, cognitive, moral and aesthetic elements. But in its core, it is not only a historicalcognitive, but also a historical-social and historical-emotional process.

The main issue is moving towards each other and continuing together along the same path. But this is not at all easy; it has some mental preconditions: taking distance from the past without forgetting the past, not allowing the past to completely determine the present, looking for the conditions and chances of a common future. Thus, every side has to change its habits a bit and has to anticipate the other side's reaction: avoiding the simple traditional and exemplary patterns of making sense means achieving complex critical and genetic patterns of making sense (see Rüsen 1994a, p. 85-90, 141-155, 231-235).

In particular, the process demands continuously changing and comparing the perspectives to history, the criteria of selection, the attributions of causes, that means looking through the eyes, walking in the shoes of the "other", even the "enemy", singing the songs and telling the stories of the "enemy". But empathy in order to understand the "other" is not enough. It leads to systematically comparing and exchanging the historical narratives, the historical orientations (consequences for the present, conclusions for own actions). Sometimes, changing one's own position becomes inevitable: abolishing historical falsifications and 
biased myths about superiority and particular dignity ("being chosen, being selected") of ones own group and the inferiority or lack of dignity ("being damned, being degenerate") of other groups.

Profoundly understood, this approach to history has a universalist basis: acknowledgment of universal and valid civil and human rights. Only after a serious study of contrasting concepts can one accomplish the construction of new, plausible and convincing histories, at least compatible (i.e. non exclusive) ones or partly common (i.e. agreeable) ones. Superficially, this version of history looks like a weakening of one's own position, like a loss. But this is short-sighted: The superior inclusive, encompassing - narrative allows self-esteem out of own achievements and abilities, not borrowed from the so-called (often dubious) heroic deeds of the ancestors. This means strength, not weakness, because there is a development in one's own personality. In the end it may bring about tolerance - even mutual sympathy and mutual acceptance - for the other, in spite of the forefathers' hatred. ${ }^{13}$

Table 2: Mental Strategies of Historical Reconciliation

\begin{tabular}{|l|l|l|l|}
\hline & $\begin{array}{l}\text { Understanding } \\
\text { history }\end{array}$ & Revising behavior & $\begin{array}{l}\text { Dealing with the } \\
\text { 'other' }\end{array}$ \\
\hline $\begin{array}{l}\text { Lower } \\
\text { distance) }\end{array}$ & $\begin{array}{l}\text { Avoiding simple } \\
\text { traditional' and } \\
\text { 'exemplary' pat- } \\
\text { terns of making } \\
\text { sense }\end{array}$ & $\begin{array}{l}\text { Abolishing histori- } \\
\text { cal falsifications } \\
\text { and biased myths } \\
\text { about superiority } \\
\text { and inferiority }\end{array}$ & $\begin{array}{l}\text { Taking distance } \\
\text { from the (own and } \\
\text { foreign) past without } \\
\text { forgetting the past }\end{array}$ \\
\hline $\begin{array}{l}\text { Interme- } \\
\text { diate steps } \\
\text { (move- }\end{array}$ & $\begin{array}{l}\text { Changing and } \\
\text { comparing perspec- } \\
\text { tives on history and } \\
\text { criteria of selection }\end{array}$ & $\begin{array}{l}\text { Going towards } \\
\text { each other and go- } \\
\text { ing on together (in } \\
\text { life and historiog- } \\
\text { raphy) }\end{array}$ & $\begin{array}{l}\text { conditions and } \\
\text { chances of a com- } \\
\text { mon future (in spite } \\
\text { of hostile history) }\end{array}$ \\
\hline $\begin{array}{l}\text { Higher } \\
\text { steps } \\
\text { (mutuality) }\end{array}$ & $\begin{array}{l}\text { Systematically } \\
\text { comparing and ex- } \\
\text { changing historical } \\
\text { narratives and ori- } \\
\text { entations }\end{array}$ & $\begin{array}{l}\text { Constructing new, } \\
\text { plausible histories, } \\
\text { at least compatible } \\
\text { or partly common }\end{array}$ & $\begin{array}{l}\text { Developing toler- } \\
\text { ance - even mutual } \\
\text { sympathy and mutu- } \\
\text { al acceptance - for } \\
\text { the 'others' (includ- } \\
\text { ing their history) }\end{array}$ \\
\hline
\end{tabular}

Clearly, this includes a new approach to, use of and coping with history, a change in the traditional notion of history itself. It is no longer a fixed

13 One of the consequences of a process of reconciliation could be to learn to mourn in common ceremonies, as Germans and French meanwhile sometimes do when commemorating World War I and World War II. 
and unchangeable value to hold on to, to preserve, but a valuable, and also hazardous, field to handle in an intellectually convincing and morally honest way.

\section{Four approaches to "historical reconciliation" via "learning history"}

Until now, nothing has been said about children and schools. In fact, all the problems and processes mentioned before take place in all parts of society, they are deep, often unconscious movements of the political and historical culture. Since historical awareness and historical interpretations are learnt by socialization, young people will clearly be involved in those changes. Often the generation growing up will turn to an alternative version, will promote opposing ideas and therefore will accelerate societal movements. This is a typical structure of the generation conflict in history.

Nevertheless, any political class, any ruling group, tries to implant its historical constructions, which in fact include the anticipated tasks for the future, into the thoughts, plans (and dreams) of the young ones, at least of those who will be influential (see Weniger 1969). History textbooks are a battlefield for this; winning means shaping the thoughts of young people, losing means a defeat in the transfer of ones own ideas to the next generation. Inevitably, history teaching in schools is history policy, even if a strong orientation towards historical science is claimed and aspired.

In the German case, we mainly executed and experienced four approaches to reconciliation in the more narrow field of learning history, especially at school and in the subject matter history:

- History textbook commissions and purification of textbooks,

- Common textbooks,

- Youth exchange programs,

- Comparing history textbooks and exchanging historical narratives by the pupils themselves.

Now we need to describe all four strategies in detail and to explain their effects and limits. 


\subsection{History textbook commissions and purification of textbooks}

Already in the twenties before World War II, many left-wing teachers in different countries, e.g. Germany and France, had begun common work in comparing and correcting history textbooks in a mutual process of examining, discussing and deciding. The aim was not to find a uniform version for both sides, but to mitigate the hatred and the mistakes in order to find some solutions and some discourses with the aim of agreeing to disagree (controversial discussions are better than firing at each other). Already in those early times, the aim was explicitly called decontamination of the national history textbooks.

After World War II, a German professor of teachers' education in Brunswick, Georg Eckert (born 1912), took up the same activity. When Eckert died in 1974, a scientific institution with his name was founded and funded; until today it has edited a periodical and a long series of more than one hundred books (see Pingel 1995; 1999, 2000; Becher/Riemenschneider 2000). After long years, a series of textbook commissions was institutionalized with the help of the UNESCO. They were not governmental institutions, but produced a mixture of scientific expertise, peace-education policy and diplomatic negotiations. In fact, those processes of exchanging and understanding need a long time. Both sides have to gain confidence in each other step by step, and also insight into the special wounds, taboos, neuralgias and limits of both sides. That is a good reason why international help and status via the UNESCO is preferable to receiving support from national governmental agencies only. The commissions need a certain independence and distance from national blinkers.

Perhaps some remarks are necessary about the main method of the commissions' work. The neuralgic topics of the bi-national history are presented scientifically by both sides and the controversies are discussed. But textbook analyses - conducted cross-nationally - are even more important. In those mutual researches and diligent comparisons, the points which one partner cannot accept in the other's official narratives are identified. After that, scientific debates about interpretation and synthesis of history and about the cultures of history, the images of and dealing with history in the societies involved, has to take place again. Between both sides in the commissions, a difficult and long process of scientific and diplomatic negotiation - even bargaining - begins and hopefully comes to a mutually acceptable end, a common recommendation. 
In this process, not every problem can - and should - be settled by an uneasy compromise in the middle; sometimes it may be better to agree to disagree in some points and to preserve this rest for the common future, when more insight and trust have evolved through the improvement of negotiation and exchange. Of course, the method can be applied to tri-lateral or multi-lateral textbook talks as well (German, Polish and Ukrainian or German, Russian and Baltic or German, US and Israeli or European and Latin American). But, as far as I know, this has seldom been wholly accomplished and has proven to be even more difficult than bi-lateral work.

The results of those commissions were textbook recommendations, not textbooks. The different systems of textbook production of the different partners were accepted. Some countries have rather varied textbook types and series on a free capitalist market, others have official and centralized (uniform) textbooks. Of course, the effect or success of the recommendations was tested and examined after some years. Often, one side was not satisfied with the publishers' practice in another country. Nevertheless, in the long run, most recommendations were fulfilled.

The German-French textbook reconciliations in the fifties were the first ones. Later on, the Israeli-German and Polish-German textbook commissions were the most important ones. The German-Polish case has become the most famous or most infamous. It took place at the time of the policy of détente ("Entspannungspolitik") of Chancellor Willy Brandt. To summarize the conflict: Germany conquered Poland in 1939, took great parts of the territory, shot a huge number of people from all elites, killed three millions Polish Jews, displaced hundreds of thousands of Polish citizens and forced millions of them to work in Germany during the war. After the war, Poland (and Russia) took the Eastern quarter of Germany (mainly inhabited by German speaking people) and drove out - or did not allow to return - a population of about nine million Germans (ethnic cleansing). There is a lot of pain and hatred on both sides - and in a very asymmetric case.

During the textbook negotiations, a precondition had to be accepted. The Polish side was prohibited by its government to talk about the Hitler-Stalin pact of 1939 with the plan to separate and abolish interbellum Poland, giving the West to Germany and the East - today's Western Belorussia und Western Ukraine - to the Soviet Union. This secret additional protocol to the Hitler-Stalin-treaty of 1939 was officially called a Western secret intelligence falsification. Only in 1989 did Gorbachev admit to the existence of the document. But in 1969 or 1972, every mention of the loss of Eastern Poland was strictly forbidden. When the rec- 
ommendations of the bilateral commission came out in 1976, the problem - like others - was excluded and postponed to the future.

The conservative opponents of Willy Brandt's policy of détente including the conservative party leaders - were immediately up in arms and accused the German members of being traitors of historical truth and German interests (Jacobmeyer 1979). Indeed, they produced an alternative recommendation which looked much more convincing and plausible to German readers (Menzel et al. 1978). Ironically, it had only one mistake: It was a German position, not a common one that also incorporated the Polish viewpoint and Polish history culture. Affirming one's own position and securing it in documents full of pathos is just the opposite of a reconciliation by history.

If the textbook publishers write the opposite of what has been negotiated and decided in history textbook commissions, this is a problem. But if they simply omit a topic which had been considered and - after long controversies - agreed upon, they may undermine the common solution or they may decide in favor of more important themes. History inevitably is selection. Many topics the researchers or politicians of one country want to fix not only in their own curriculum but also in the one of their - formerly hostile - neighbor cannot be covered in detail or at all. Every country has to accept that others learn a different history. This is not easy. But in instances where a neuralgic issue is covered in one country, the others have a legitimate right to look at it and perhaps voice their differing opinions and respectful protest. ${ }^{14}$

\subsection{Common textbooks?}

The concept of a common textbook has to be sharply distinguished from the concept of textbook examination and textbook decontamination. Different states, nations, and regions remember different histories and therefore merit different textbooks, but - that is the result of a successful textbook commission - not at the emotional costs of the neighbour. Textbook negotiation (even textbook bargaining) is a question of good diplomacy, of intellectual honesty and of anticipatory peace-keeping. Common textbooks are a question of identity policy, of a type of second order nation building (or federation/alliance building). About twenty years ago, a private donator financed a common "European History

14 Commentaries from other positions ("controversial articulations") are a good alternative to common history texts. This is not only true for (formerly hostile) nations, but for classes, genders, religious communities etc. as well. Remember that international history with diplomacy, trade, war and peace is not the only aspect of history! 
Textbook", written by more than ten scientists coming from more than ten countries (Aldebert 1992).

In my opinion the result was not convincing. On the one hand, the different versions in different languages have not been completely identical. Central notions and remarks varied. On the other hand, the text was rather abstract and boring. In this, it fell far short of the best textbooks in many European countries. ${ }^{15}$

Obviously, the same textbook has completely different effects in small countries (like Czechia) and large countries (like France), in geographically central countries (like Germany) and marginal countries (like Norway), in conservative countries (with a tradition of learning by rote, falsely called "learning by heart") and in progressive countries (with a tradition of free learning). The idea of a common textbook, although it is often renewed in the public discussion, is not a good idea. What we need, is not a common history, but a history for every country with a common European aspect and perspective on one hand, and a basic idea of European peace and reconciliation on the other. This noble dream has not yet been wholly accomplished.

A second attempt to produce a common textbook was made by the French president Jacques Chirac and the German Chancellor Gerhard Schröder. A German-French youth conference itself had made the proposal; and the two leading politicians pushed it through against some experts' warnings and all legal impediments (top-down-model). Now the second and the third volume have been published (Histoire/Geschichte 2006, 2007); chronologically they cover modern and contemporary history. It may be more difficult to agree when it comes to earlier periods. ${ }^{16}$ Contrary to what the top politicians had in mind, almost nobody thinks that it can be used alone and exclusively. It is accepted as additional material only. The two partners' common book is far from being a solution. ${ }^{17}$ As a thought experiment, you only have to think about a generali-

15 Perhaps an important illusion has to be destroyed: The content of history textbooks is not really learnt or internalized by the students. Therefore the quarrel for proportions and inclusion often resembles a shadow-boxing. 80 to $90 \%$ of the facts and topics covered in history lessons will be forgotten only one year later; only identity-relevant interpretations will be retained for a long time. Teaching does not mean ordering learning or enforcing learning, it can only stimulate or encourage learning.

16 But even in this case, the compromise was not easy (at least, there are hints): In the common textbook Germans stressed multi-perspectivity and the French value education.

17 Germany, for instance, has nine direct neighbours (not to mention the countries overseas that Germany has had historical ties with): The Netherlands, Belgium, Luxemburg, France, Switzerland, Austria, Czechia, Poland and Denmark. 
zation of the project of bilaterally common history textbooks. Can we want and use a British-German, a US-German, an Italian-German textbook - and many others - as well? We cannot. This is only possible - if at all - for one privileged partnership (as an anticipation of a closer unity?).

The Polish reaction to the German-French plan was very typical and very contradictory. On the one hand, Poland wanted to participate, to join a trilateral project. On the other hand, a parallel German-Polish project was demanded. And finally, a strong polemic discussion against the whole idea broke out and became dominant: As a perfectly sovereign nation, Poland cannot accept any interference in its textbooks. AntiGerman slogans were uttered, even by the Polish government. ${ }^{18}$ Reconciliation - as a long process - is mutual alteration and rapprochement, but not unification or uniformity. Experiments in adopting the really differing perspectives of others (empathy) may be superior to pre-given uneasy - and un-loved - compromises.

\subsection{Youth exchange and youth encounter}

Extensive programs of youth exchange and encounter are not possible without a lot of money; they do not effect positive results of reconciliation automatically and they often do not include much historical learning. ${ }^{19}$ These points need to be mentioned at the beginning. Nevertheless, youth encounter and exchange are very important and perhaps the best of all concepts (Dethlefsen 2003). Many German school pupils of the higher grades in privileged types of school spend one year in a foreign country, normally France, Great Britain, and the USA, but also Canada, Australia, Spain or Italy. Exchange programs with Russia, Poland and Czechia exist as well, but the number of participants is lower and the exchange periods are shorter.

The special exchange programs are of another type; they are conducted in groups, with normally whole classes visiting France or Poland. And entire Polish and French classes come to Germany in mutual exchange programs. In the French case, a particular treaty was signed more than thirty years ago, and heavy funding was effected. Millions and mil-

18 This took place from 2005 to 2007; in October 2007, the Polish People elected a new parliament and the Polish parliament elected a new government (Donald Tusk) in November. A careful policy of rapprochement to Germany began immediately, even in the field of history policy. The common work for a common German-Polish history textbook has meanwhile begun. But the German - Polish relations remain complicated.

19 At least, this is the impression after observing the experiences of the German-Polish-Youth-Exchange Organization. 
lions of young people have meanwhile visited the other country. In the Polish case, the parallel organization, the "German-Polish YouthExchange Organization", was founded only after the fall of the Berlin wall in 1989 (and it received far less money). Nevertheless, millions of young students have gone to Germany or to Poland. Unfortunately a German-Czech agreement has not yet been accomplished, because of repeated public discussion within both countries.

The linkage of youth encounter and reconciliation by means of historical learning is not really close. In the case of Poland, we know very well that doing sports, music, shopping, comparing fashion and dancing together is much easier for the young boys and girls than discussing history. Often they understand each other immediately if they do not talk about history. Often mixed friendships last for a long time, and there are also cases of love relationships. Thus, one might suggest that history only impedes reconciliation instead of promoting it. In fact, teachers often avoid history in such German-Polish exchanges instead of itemizing it.

A very important exception has to be mentioned. From the German side, many excursions are organized to the sites of the extermination camps of Auschwitz, Maidanek, Belzec, Treblinka, Sobibor etc. Financially, these trips are paid for by the German-Polish Youth-Exchange Organization like exchanges, even if there is no encounter with Polish students. Here, the asymmetric situation - German mass crimes in Poland 1939 to 1945 - is taken into account.

The practice of German-Polish encounters reflects the difficulties of historical reconciliation. As already said, history (except the history of the NS period) is often excluded or avoided - and the students therefore like each other. Unfortunately, historical consciousness takes revenge (like a restless and irreconcilable ghost), if it is omitted. The development of the last years clearly shows that history returns subconsciously (through the back-door) like a revenant if you try to exclude it consciously (via the front door). When the Polish government began with an anti-German policy, when it used anti-German feelings to promote conservative party policy, it became evident how thin, fragile, and endangered the practice of reconciliation actually is. ${ }^{20}$ Resentment and prejudices dominate, instead of historical analysis. The majority is helplessly exposed to such tactics of history poetics.

The "German-Polish Youth Encounter Organization" clearly decided to promote common historical work of German and Polish groups, in the sense of local research projects (e.g. NS history, former German popula-

20 This concerns the years 2005 to 2007 again; conditions changed with the re-election of October 2007 (see above). 
tion in now Polish cities). But these are long-term projects. First, teachers have to learn and to work together. The early attempts have clearly shown a very different culture of history. ${ }^{21}$

Polish teachers (like Polish students) know a lot about history, but most of it is closely connected to a limited, even fixed interpretation ("myth") of Polish history. There is only one, clearly nationalistic version (based on an a-historical understanding of "nation"). Certainly we can call this an integral nationalistic mode of making sense of history. The master narrative of history constitutes the nation (and has saved or preserved it during 120 years of partition from 1795 to 1918). History is used - but not acknowledged and reflected - as construction of identity. And this national identity is that of a victim's history and a homogenous nation (not at all convincing in the case of the Polish nobility's republic with Lithuanian, Ukrainian, Belorussian and German noblemen belonging to the Polish nobility nation before 1795).

German teachers - like German pupils - often know much less about history than the Polish ones. But their pattern of interpretation is normally no longer national or nationalist. The history of the German nation means guilt and shame since National Socialism. Therefore, the interpretation is mainly organized in a European or universal history perspective. Additionally, Germans are prepared to listen to differing types of making sense. Many of them have already moved to a "constructivist" concept/theory of history (hopefully!). They are more ready to compare and discuss other narratives - and perhaps to change their own opinions. An interchange between a rich, but narrow Polish and a poor, but flexible German version is very difficult, often uncomfortable and irritating. Thus, teachers have to be prepared to guide the students during their common history projects. First experiences with teachers' summer courses have been collected.

Without any doubt, experienced teachers und students can do good work. For about ten years, there has been a network of students' history competitions (Eustory 1999). Promoted by the Körber-Foundation in Hamburg, the approx. eighteen competitions from France to Russia, from Italy to Ireland, from Bulgaria to Estonia exchange their ideas and their winners. Common workshops are used to tell each other the respective investigated history and to investigate new topics together. It takes

21 Here I rely mainly on my own experiences in a couple of seminars with teachers of both countries (and some scientific meetings). Additionally in 1995, the questioning of 1250 teachers and 31500 ninth graders in 27 countries (see Angvik/Borries 1997; Borries et al. 1999: 85-89, 92-91, 95, $125,174,185,187,241,302,304-311$ etc.) showed marked differences in German and Polish cultures of history and cultures of learning. 
some time - and some language difficulties have to be solved, but the results are encouraging. Exhibitions and books have been produced. Long-term friendships have started (e.g. Wancerz-Gluza 2003). The best experiences were made in common summer-courses and international networks (e.g. EUSTORY 2007).

\subsection{Comparing history textbooks and exchanging historical narratives among pupils themselves}

Regional history research projects of school students are a good idea, but they only cover small fields. There is another chance to initiate an international debate or discourse among students themselves, e.g. through the comparison of textbooks. In 2006, a small pilot-study was done, financed by a German foundation. Students in many countries compared the textbook chapters about 1989/90 (the fall of the "Berlin Wall" and the "Soviet Empire"), presented their results to classes from other countries and revised them together. Very similar work was previously done with Polish and German teachers.

In some respects, communicative textbook comparison (and responsible textbook revision) is better than pre-fabricated purged versions after comparison by scientific textbook commissions. Of course, gross falsifications, myths or tirades of hatred can be eliminated beforehand. But the simple fact of completely different selections, perspectives and interpretations (and identity contributions) is striking for both sides. Similar experiences took place in several internet projects, but - and that is a restriction - the language problems proved to be a crucial issue.

Perhaps the logic of this fourth method has to be explained a bit more in detail. When textbook decontamination started sixty years ago, scientific work normally took place in national frameworks. In the process of the textbook commissions, nobody learnt more than the members of the commissions themselves. They broadened their horizons, they repeatedly changed their perspectives, and they developed a multiperspective and a meta-perspective, without losing their individual - and national or cultural or religious - position. Today, in the era of globalization, school pupils travel and communicate as much or more than scientists did sixty years ago. Why should we not give them the same chances which were presented to the professors two generations ago? They will discuss their historical interpretations anyway. Why not prepare and organize this process systematically - and with the help of translations? The first experiments were very successful, although so far only among elite students. 
To sum up: Reconciliation via history and coping with burdening history is a long-term project and program (for individuals as well as for societies). It needs reflection and (self-) reflection, not only more historical knowledge, but more self-distance, empathy and - as far as possible - mourning as well. It may be encouraged at school, but mainly challenges individual and public emotions and activities.

\section{References}

Aldebert, Jacques et al. (1992): Europäisches Geschichtsbuch. Geschichtliches Unterrichtswerk für die Sekundarstufe I und II, Klett, Stuttgart.

Angvik, Magne and Borries, Bodo von (eds.) (1997): YOUTH and HISTORY. A Comparative European Survey on Historical Consciousness and Political Attitudes among Adolescents. Volume A: Description, Volume B: Documentation (containing the Database on CD-ROM), edition Körber-Stiftung, Hamburg.

Becher, Ursula A. J./Riemenschneider, Rainer (eds.) (2000): Internationale Verständigung. 25 Jahre Georg-Eckert-Institut für internationale Schulbuchforschung in Braunschweig, Hahn, Hannover.

Borries, Bodo von (unter Mitarbeit von Körber, Andreas, Baeck, Oliver und Kindervater, Angela) (1999): Jugend und Geschichte. Ein europäischer Kulturvergleich aus deutscher Sicht (= Schule und Gesellschaft 21), Leske\&Budrich, Opladen.

Borries, Bodo von (2004a): “Was geht uns eure Geschichte an?' Geschichtsunterricht in einer Einwanderungsgesellschaft”. In: Sowi (Sozialwissenschaftliche Informationen), 33. Jg. 2004, Heft 2, pp. 62-73.

Borries, Bodo von (2004b): "Lernen und Lehren zum Nationalsozialismus 2004". In: Wilhelm Schwendemann/Georg Wagensommer, (eds.), Erinnern ist mehr als Informiertsein. Aus der Geschichte lernen (2) (= Schriftenreihe der Evangelischen Fachhochschule Freiburg 28) Münster (Lit), pp. 48-74.

Borries, Bodo von (2005): “Aus Geschichte lernen im Just-in-timeZeitalter? - zu erhofften Zukunfts-Leistungen des Faches Geschichte". In: Thomas Schlag/Michael Scherrmann (eds.). Bevor Vergangenheit vergeht: Für einen zeitgemäßen Poltik- und Geschichtsunterricht über Nationalsozialismus und Rechtsextremismus, Wochenschau, Schwalbach/Ts, pp. 43-63.

Borries, Bodo von (2006a): "Lernen und Lehren zum Holocaust - Konventionen, Irritationen, Provokationen?”. In: 'Wie sagen wir es unse- 
ren Kindern?' Die Behandlung der Shoah im schulischen Unterricht; (= epd-Dokumentation Nr. 4/5, 24. Januar 2006), Gemeinschaftswerk der Evangelischen Publizistik, Frankfurt/M, pp. 48-65.

Borries, Bodo von (2006b): "Holocausterziehung und Kolonialismusdebatte”. In: Politisches Lernen 24. Jg., 1-2/2006, pp. 15-20.

Borries, Bodo von (2008): Historisch Denken Lernen - WelterschlieBung statt Epochenüberblick. Geschichte als Unterrichtsfach und Bildungsaufgabe (= Studien zur Bildungsgangforschung 21), Barbara Budrich, Opladen und Farmington Hills.

Borries, Bodo von (2009): "History Education for Historical Reconciliation: Some Theoretical Considerations and some Practical Experiences from a German Perspective”. In: Opening Historical Reconciliation in East Asia through the Historical Dialogue, Seoul, pp. 225264.

Dethlefsen, Knut (ed.) (2002): Erinnern und Gedenken. Zur Bedeutung der historisch-politischen Bildung im deutsch-polnischen Jugendaustausch, Deutsch-polnisches Jugendwerk, Potsdam/Warschau.

EUSTORY (1999): The Network of History Competitions in Europe, edition Körber-Stiftung (= EUSTORY-Paper 1), Hamburg.

EUSTORY (2007): Sharing Memories of Protest and Resistance. Young Europeans Confront History Anew, Körber-Stiftung, Hamburg.

Histoire/Geschichte (2006): Europa und die Welt seit 1945, Klett, Leipzig.

Histoire/Geschichte (2007): Europa und die Welt von 1815-1945, Klett, Leipzig.

Jacobmeyer, Wolfgang (1979): Die deutsch-polnischen Schulbuchempfehlungen in der öffentlichen Diskussion der Bundesrepublik Deutschland. Eine Dokumentation, Diesterweg, Frankfurt/M.

Jonas, Hans (1984): Das Prinzip Verantwortung, Suhrkamp, Frankfurt/M.

Jonas, Hans (1987): Technik, Medizin und Ethik. Praxis des Prinzips Verantwortung, Suhrkamp, Frankfurt/M.

Liebsch, Burkhard/Rüsen, Jörn (eds.) (2001): Trauer und Geschichte, Böhlau, Köln.

Menzel, Josef Joachim et al. (1978): “Alternativ-Empfehlungen zur Behandlung der deutsch-polnischen Geschichte in den Schulbüchern (1978)". In: Landtag Rheinland-Pfalz: Deutschland und Polen im Schulbuch. Parlamentsdebatte in Mainz, von Hase \& Köhler without year [1979], Mainz, pp. 89-124.

Nietzsche, Friedrich (1968): Jenseits von Gut und Böse. Zur Genealogie der Moral (= Kritische Gesamtausgabe VI,2), Berlin, Walter de Gruyter. 
Pingel, Falk (ed.) (1995): Macht Europa Schule? Die Darstellung Europas in Schulbüchern der Europäischen Gemeinschaft (= Studien zur internationalen Schulbuchforschung 84), Diesterweg Frankfurt/M.

Pingel, Falk (1999): UNESCO Guidebook on Textbook Research and Textbook Revision, Hahn, Hannover.

Pingel, Falk (2000): The European home: representations of 20th century Europe in history textbooks, Council of Europe Publishing, Strasbourg.

Rüsen, Jörn (1994a): Historisches Lernen. Grundlagen und Paradigmen, Böhlau, Köln.

Rüsen, Jörn (1994b): Historische Orientierung. Über die Arbeit des Geschichtsbewußtseins, sich in der Zeit zurechtzufinden, Böhlau, Köln.

Wancerz-Gluza, Alicja (ed.) (2003): Grenzerfahrungen. Jugendliche erforschen deutsch-polnische Geschichte, edition Körber-Stiftung (Polish edition also), Hamburg.

Welzer, Harald et al. (2002): 'Opa war kein Nazi'. Nationalsozialismus und Holocaust im Familiengedächtnis ( $3^{\text {rd }}$ ed.), Fischer, Frankfurt/M.

Weniger, Erich (1969): Neue Wege im Geschichtsunterricht (4th ed.), Schulte-Bulmke, Frankfurt/M. 

III The Mediation of History in Practice 



\title{
Exhibiting the War. Approaches to World War II in Museums and Exhibitions
}

\author{
OLA SVEIN STUGU
}

Traditionally, war exhibitions have functioned as media for officially sanctioned narratives of sacrifice and victory. After World War II new kinds of exhibitions have developed, balancing between moral messages and research-based narratives. What does this development mean for the role of museums in shaping historical consciousness?

Museums are among the most important institutions molding historical consciousness in modern society. Through the ways of selecting and editing which past is worthy of being presented in exhibitions, museums convey values, concepts and thought models not only as orienting tools for the present, but also as guidelines for future action. During later decades historical museums in general have undergone substantial changes within the ways of representing and presenting the past. In accordance with this, approaches to war in museums and exhibitions staged in other institutional settings have also changed. Yet these changes should not only be understood in the light of developments within the museum institution itself but also in accordance with changing focuses in reflections and interpretations of the war. This article aims at exploring and discussing these changes in light of recent theory of memory, identity and uses of history.

In the grand narratives of the great historical museums from the middle of the 19th century and onwards, war, as a rule, was depicted as an integral, sometimes unavoidable part of shaping and securing the state. The national museums were to a large degree public institutions with manifest missions to serve the nation and support hegemonic na- 
tional narratives of the time. The greatness of the nation demanded great deeds from its sons (and from time to time even from its daughters), and museum exhibitions were designed to install pride and patriotism in their visitors. War exhibitions, with their narratives of us and them, heroes and villains, bravery and pride, were particularly well suited for this purpose. Exhibitions with a more specific military focus usually contained weapons, uniforms and banners, while exhibited pieces of art illustrated heroism and sacrifices for the good, worthy cause. The enemy was usually one-dimensional, and on several occasions cruelty and a breach of the code of honorable conduct on behalf of the enemy were displayed as a means to boost morale and strengthen identity on one's own side.

The enemy was not necessarily shown as evil or treacherous. If he had fought bravely or behaved chivalrously, he was respected, sometimes even admired, like the position of the confederate commander-inchief Robert E. Lee within the narratives of the victorious side of the American Civil War. Nevertheless, the distinction between friend and foe was always clear, and the behavior of one's own side was hardly ever questioned.

Following World War I, the experiences of the trenches also made exhibitions focus on the fate of the ordinary soldiers, but whereas the absurdity and cruelty of the slaughter became a central topic in scholarly debate as well as in literary fiction, museums rarely managed to integrate these aspects of war in their exhibitions. This may partly be ascribed to the fact that most museums focused on collecting and preserving artifacts of the war and cared less for the themes of history, which did not manifest itself materially. But it may also be seen as a continuation of the understanding of museums as patriotic institutions with an educational mandate to help produce good, loyal citizens, prepared to bring new sacrifices for their country.

After World War II, the one-dimensional friend and foe narratives are still to be found in quite a few museums. The overall picture, however, has become much more ambiguous and inconsistent. New themes and topics have found their way into exhibitions, even at official national institutions, and most museums no longer consider themselves obliged to prop up national identities and master narratives. This does not mean that the main trend in these institutions has been a turn to challenging the established narratives, but public discussions about the war have unavoidably left deep imprints also within the museum world. War exhibitions no longer restrict themselves to telling narratives of the past, they have also become arenas for discussing abuse of human rights at 
large as well as other moral dilemmas. These tendencies are most clearly seen in Germany, but can be noticed in other nations too.

To clarify these processes of change, some basic questions concerning the presentation of historical knowledge and insights have to be asked: To which degree do exhibitions present authoritative master narratives of events in contrast to open ended, discussing approaches? How much is still to be seen of the classical identity-based contents? How do exhibitions answer the challenge of finding a balance between the ideals of the research community of critical, non-partisan investigation and discussion on the one hand and the aim to educate and to convey basic values on the other? Are there significant differences between exhibitions aiming at different audiences and target groups? Are there important differences in the form of exhibitions and how does this relate to their contents? This last dimension above all considers the difference between object-based exhibitions where collected items are central and concept-based exhibitions where attention is focused on messages, regardless of whether there are artifacts or other objects at hand to illustrate and underline the narrative and message told within the exhibition. (Dean 1996: 4pp.)

Below I will broadly distinguish between two main types of war exhibitions, the first one communicating national narratives much in line with traditional historical museums, and an alternative one, basing focus and activities on universal values, usually including human rights and adherence to an open, democratic society. What separates the two types of exhibitions is the character of the values they support and wish to convey. This means that within both types one may find exhibitions following high academic standards as well as exhibitions where the message overrules research-based conclusions.

A brief note also needs to be added on what is meant by a museum. Museums are usually regarded as places containing and exhibiting material artifacts and objects. This is reflected e.g. in the definition of a museum approved by The International Council of Museums, which defines a museum as a: "a non-profit making, permanent institution in the service of society and of its development, and open to the public, which acquires, conserves, researches, communicates and exhibits, for purposes of study, education and enjoyment, material evidence of people and their environment" (Ambrose/Pain 2006: 8). This definition excludes museum-like institutions of research and education-producing exhibitions that are to a large degree concept-based. In my discussions, however, these institutions will play an important role, not least because they often serve declared educational purposes and defined universal values. 
Therefore they have at least implicitly been forced to deal with the question of the historical consciousness of their visitors.

\section{The patriot narrative}

After World War II, the patriot master narrative of fighting, hardships and sacrifices for the country, liberty and other good causes is well represented in war exhibitions. The point of view is normally clearly partisan, presenting “our own, our parents' and our grandparents' war". For obvious reasons narratives of this type are normally to be found on the victorious side. However, they differ from earlier patriot narratives by not glorifying the own nation's victories as the main achievement of the war. Instead, as a rule, they legitimize the war efforts as a fight for justice and honorable general values against dictatorship, oppression, injustice and the inhumanity and barbarism of the enemy.

The Norwegian Resistance Museum, situated at Akershus fortress in Oslo, is a paradigmatic example of this master narrative approach. The museum is also a research institution with extended educational activities, centering on the main exhibition of the museum, which has been left largely unchanged since its establishment in the early 1970s. The exhibition tells an unambiguous story of invasion and collaboration, resistance and victory, heroes and villains with limited space for alternative perspectives, questions and discussions. The narrative is very much in line with the way in which war history has been presented in history textbooks during most of the post-war period, and it may easily be considered an authoritative version of the national Norwegian war narrative. The exhibition builds upon thorough scholarly research, and, apart from questionable omissions of allied activities in sections of the exhibition covering the prelude to the German invasion, it is difficult to raise serious objections against the treatment of any of the subjects. Above all, what makes this exhibition an orchestrated master narrative is the way in which themes and events have been chosen, highlighted and linked together by help of an authoritative, undisputable mode of presentation. ${ }^{1}$

Without doubt the best known Western European master narrative museum is the Imperial War Museum, founded in 1920 to commemorate British participation in the First World War and to collect items connected to the war effort. It gradually developed into a general museum of war during the 20th century, and might be seen to epitomize the grand

1 http://www.mil.no/felles/nhm/start/Utstillingen/\#= Personal visits, latest March 2009. 
museum of national standing taking great pride in its collections. The museum announces on its website:

"Chronicling the history of conflict from the First World War to the present day, the Museum's vast collections range from tanks and aircraft to photographs and personal letters as well as films, sound recordings and some of the twentieth century's best-known paintings."

Since its first years, the museum has shifted the focus from its original nationalistic perspectives to a more distanced, scholarly approach with a broad appeal, not least to schools. Recently the museum has tried to reinvent itself by adding a Holocaust exhibition and a specially commissioned film on human rights violations. But the main impression of the major parts of the museum is still that of solid, traditional presentations, well founded in historical research, but virtually devoid of surprises and challenges for reflection. This does not mean that the exhibitions are value-free. The underlying message of the whole institution is to showcase the British army as a necessary tool in defending the country, the British way of life and the values of the British political system, but also to emphasize the central role of Britain in the total war effort. Regarding World War II, there is a clear tendency in the exhibitions to overestimate the British contribution to victory compared to that of the Soviet Union.

The message of a museum is not only derived from its contents, but also from the form in which the contents are being presented, which may be illustrated by the recently opened northern branch of the Imperial War Museum in Salford (Manchester). "For all its audiovisual innovation and striking building, this is a very traditional museum of the history of warfare in the twentieth century," the British philosopher Beth Lord writes in an analysis of the museum and continues:

"The museum is organized around a timeline which runs along its walls, with relevant objects arranged near the key dates. The objects illustrate the points on the timeline and fit neatly into the chronology. The space is punctuated by 'silos' using objects to illustrate big concepts that don't fit neatly into the chronology: propaganda, women at war and so on. In traditional style, the visitor moves through time as he or she moves through the museum, following the trajectory and development of the twentieth century through its wars [...]" (Lord 2007: 360)

2 http://london.iwm.org.uk/server/show/nav.182. Accessed 10/20/08. Most of the analysis is based on this large, well organized site.

3 Personal visit January 2005 
This kind of display, according to Lord, "arguably [...] is a good way of communicating a long and complex history in a short time and small space" (Lord 2007: 360). But presenting history in this way as a fixed and continuous line where one may mount events and objects is also a way of conceiving history as a kind of stable objection-free totality.

This way of presenting history may be well in accordance with deeprooted traditions in British museums. According to Tony Bennett "the British past was largely shaped through the commemoration of military exploits of empire, a tendency that was equally strong in France" (Bennet 1995: 137). This marks a contrast to another preservationist philosophy, which originated in Scandinavia, but also adopted in the United States, in which material objects of folk culture were assigned historical significance. This argument may explain differences in the main profiles of the national museums, but not the specific features of war exhibitions, where the Norwegian resistance museum seems to have much more in common with British institutions than with other historical museums within the Norway.

The Western master narrative differs substantially from the version found in Central and Eastern Europe during the era of state socialism. Like other institutions with educational purposes, museums were required to serve the overall needs of the state and the ruling party. Consequently exhibitions had to adjust their messages to the party version of history, which means that the victorious adversary of Nazi barbarism and inhumanity was not the liberal democracy, but socialism and people's democracy. This was not least the case in the Soviet Union, where the sufferings and hardships of war made sense as a necessity to preserve not only the political system, but also the nation itself.

This aspect of the war narrative has become even more crucial after the fall of the Soviet Union, a fact well illustrated in the new Central Museum of the Great Patriotic War, which opened in Moscow in 1995. In contrast to earlier Soviet representations, which glorified Stalin and the Party as the great leaders of the war effort, the museum has shown a will to also confront the more problematic aspects of the war, like the Molotov-Ribbentrop treaty, the catastrophic mistakes of leadership during the early phases of war and the fate of the prisoners of war. Nevertheless, there is no doubt about the museum's patriotic message, as illustrated by a quotation from one of the directors of its research department in 1996:

"The people were not forced to fight, pressured by political institutions. They fought consciously for their fatherland, for Russia. And we won, not because 
of but despite the inhuman regime of oppression and terror. Here are the roots of our victory." (Prusakova 1997: 87)

An almost ideal typical example of a nationalist military museum is to be found at the old Kalmegdan fortress in Belgrade. The Kalmegdan military museum was founded in 1878 , shortly after the war when Turkey lost control over large parts of the Balkans. During the era of Tito the authorized narrative of the Yugoslav partisan war 1941-45 was a highlight of the museum. It still boasts Serbian resilience and resistance, e.g. by displaying parts of an American stealth bomber destroyed during the 1999 war. $^{4}$

Within the former GDR, the memorials at the Nazi concentration camps of Sachsenhausen, Ravensbrück and Buchenwald were organized in a way that not only displayed a well-documented presentation of the history of the sites until 1945, but which also intended to demonstrate Communist resistance against the Nazi regime. This was particularly the case at Buchenwald, which had the strongest concentration of Communist inmates of all camps during the period. In this way, the memorials also showed how the GDR regime actually belonged on the side of the victors of the war - in contrast to the Federal Republic. After the reunification of Germany the presentations and the narratives they conveyed were replaced by newer ones more in line with the history being told at other German memorials. At Buchenwald, the old exhibitions have been supplied with two new exhibition buildings, one focusing on the site's usage as a prison camp during the early days of the Soviet occupation, the other one presenting a meta-history about the development of the exhibitions and monuments at the site between 1945 and 1989. ${ }^{5}$

These new exhibitions may even be characterized as a kind of metamuseum, an approach that has been quite rare so far. Concerning war history at large, however, an exhibition at the Imperial War Museum in London in 2008, titled "Re-vision" may be viewed as a kind of metaexhibition. There, paintings and other pieces of art from the collections of the museum were used to show ways of presenting the war through art during the first fifty years of the museum's existence. ${ }^{6}$ Hopefully this

4 The website of the museum is only in Serbian/Croatian, but the pictures on http://muzej.mod.gov.yu/stalna\%20postavka/postavka.htm (accessed 10/20/08) give an impression of a rather old fashioned object based exhibition, which seems to have changed very little since my visit in August 1974.

5 Personal visit. November 2007, cfr. http//:www.buchenwald.de/index_en. html.

6 http://london.iwm.org.uk/server/show/conEvent.2292nd. 
is only the first step towards a more comprehensive meta-museum project within that museum.

An interesting variety of the patriotic exhibitions may be found at local or regional museums with sections on the $20^{\text {th }}$ century. Of particular interest are city museums of big cities like Tokyo, London and Hamburg, which all have large sections about the local effects of the war. To a larger extent than other museums dealing with the war, these museums are able to show how war affected civilians and their lives, from the fears and sufferings following large-scale bombings to everyday struggles of finding food and shelter. However, the approach becomes problematic when local history is not properly tied to the overall structures of politics and war strategies.

The "War and Reconstruction" section of the spectacular Edo-Tokyo Museum is a good case in point. The effects of the great air raids on the city in March 1945, with the number of people killed in the firestorm exceeding that of the immediate casualties of the nuclear attack on Hiroshima, are displayed extensively. But as the civilian sufferings are not contextualized against Japanese warfare at large, the main lesson to be learnt from the exhibition is about Japanese suffering, with no reference to Japanese guilt and the suffering inflicted upon others. ${ }^{7}$

The impressive Museum of the History of Hamburg also displays a thorough and well-researched narrative, not only of events narrowly tied to the war, like the firestorm following the air raid in 1943, but also the story of the local growth of the Nazi movement and regime. A visitor cannot avoid noticing repeated statements about the local Nazi regime, which is considered relatively mild compared to the harsh repression elsewhere, but there is no mentioning of the extensive cooperation between city authorities and the SS on brickstone deliveries from the Neuengamme concentration camp to the city (On the theme of victim and guilty in national history culture see also the contribution by Ahonen). ${ }^{8}$

Most countries occupied during the war have resistance museums of various kinds. Some of them, like in Norway, are on a national level and bear an official stamp, whereas the state in France seems to have been quite reluctant to reproduce memories of the war through this type of central institutions. From the mid 1980s, however, 25 or so museums have been erected on regional and local levels with "resistance" or "deportation" in their name.

7 Personal visit April 2003, http://www.edo-tokyo.msusum.or.jp/enlish /index.html.

8 Personal visit November 2007, http://www.hamburgmuseum.de/index_e. html. (Kaienburg 1991: esp. 97 pp). 
This development seems to coincide with an increased openness in French memory culture towards the more problematic sides of French war history, particularly concerning the Vichy regime. But the fact that a majority of the institutions have been erected within Vichy controlled territory calls for further investigation, and a possible explanation suggested by Kevin Walsh is that memorizing resistance in these parts of France might be seen as an effort to counter impressions of widespread regional collaboration. In this way, regional and local institutions answer more to regional than to national needs, as Walsh suggests:

"What such an analysis reveals is that it is very difficult to discuss national memories, and in fact a regional approach to the study of identity is the only valid and useful approach [...]. No matter how hard the state tries, popular memory at the local or regional level cannot always be subsumed by the crafted national memory, constructed by national ideology." (Walsh 2007: 446)

\section{Exhibitions as media for moral messages}

After Auschwitz, a strictly value-neutral presentation of the history of World War II seems impossible, even preposterous, and it seems quite appropriate that war exhibitions signal some kind of value-based approach, not only defining the enemy as evil, but also trying to identify some of the values to be defended. Not least after the Nuremberg trials and the Universal Declaration of Human Rights in 1948 this seems to be an appropriate approach. However, there is a broad variety in how the institutions choose to communicate these values, and their main messages vary extensively. This does not least apply to the presentations of the war and its messages in the countries on the losing side.

A most interesting case in this respect is the Hiroshima peace memorial museum. Like the Edo-Tokyo museum it offers an extensive display of human suffering. However, the Hiroshima museum's approach to the past differs profoundly from that of the Tokyo museum. The museum opened in 1955 with a declared aim to contribute to abolishing nuclear weapons, and the oldest parts of the exhibition almost exclusively focus on the effects of the bomb, using quite strong effects to raise emotions and provoke attitudes. During a thorough reshaping and extension of the museum in the early 1990s, a new section was added, representing the events and developments leading up to August $6^{\text {th }} 1945$, when the bomb was dropped. This part of the exhibition maintains an analytic, reflective approach and tells different, but intertwining narratives leading up to the fatal date of the bomb. 
One narrative focuses on the development of Japanese militarism and imperialism that led to the efforts to realize the vision of an "Eastern Asian Co-Prosperity Sphere" by brute force. Another narrative tells of scientific progress, particularly in nuclear physics, which was a precondition for making the bomb. A third story follows the internal development of the city of Hiroshima, which due to its proximity to the Asian mainland became a port of departure for armies to Korea and China. A fourth one deals with American war strategies, where extensive space is given to the chilly tale of why Hiroshima was chosen as target for the first full-scale test of the new weapon, while Kyoto, with a similar topography of hills on three sides of the city, was spared because of its cultural heritage treasures. Frequent special exhibitions have focused upon sensitive topics like the early post-war period efforts on the American side to cover up the effects of the bomb, but also on politically less controversial issues like the reconstruction of the city. ${ }^{9}$

Commemorating the atrocities and guilt of one's own group or state is historically a very rare occurrence, and despite some serious efforts to include a perpetrator perspective into the exhibitions, the main approach at the Hiroshima museum is the city and its inhabitants as war victims, a position not difficult to understand or defend. Turning to Germany as the other great loser of the war, similar victim's perspectives may be found in sections of city museums dealing with the allied bombing campaign. As a rule, however, German museums and memorial sites display a clear will to admit the nation's perpetrator role, not least when it comes to the fate of the European Jews. This is not only the case at the sites of former concentration camps, but has also become so widespread in other museums and memorials that one might virtually speak of a kind of remorse industry, which has accelerated during the last 20 years or so. (See also the contribution by Borries in this volume, which presents a typology on ways of dealing with burdening pasts.)

As a whole, the institutions, particularly the latest ones, display a scholarly approach to the war and give due respect to all kinds of victims. I find it appropriate to call this approach to the war the "scholarly remorse and guilt approach". For instance, the museum exhibitions at Bergen Belsen, opened in the autumn of 2007, not only present the relatively short history of the concentration camp whose infamy British war photographers helped to bring to public attention shortly after the surrender, but also the prisoner-of-war camp at the site as well as the postwar period where it functioned as a camp for displaced persons, mostly

9 Personal visit April 2003. The Hiroshima Peace Memorial Museum (1999), http://www.pcf.city.hiroshima.jb/index_e2.html, accessed 25/11/ 09. 
Poles and Jews. The exhibitions are organized as what has been termed "study exhibitions", where materials for more comprehensive studies are available on shelves, in drawers and in digital storage media within the exhibition building. The study material is a wide selection of factual sources, and in this way it differs profoundly from the emotionally charged approach in other areas of the camp's site which were organized at an earlier time.

The exhibitions at Neuengamme are another example of the scholarly study exhibition approach which is not aiming directly at the empathy and emotions of the visitor, but instead aims at making an impact and inducing visitors to take a stand by way of reflection and insight. A special exhibition focusing exclusively on the SS perpetrators was widely discussed before opening, as some critics feared that the perpetrator focus might result in some degree of identification with the perpetrators. The danger seems to have been largely overestimated, and even when some leading SS functionaries of the camp are being followed quite closely, even with notes and pictures of their family life, the main focus is on their actions as SS members and camp personnel. Instead of identification, this approach rather raises the imminent question of what actually turned these men into perpetrators and of the interplay between the system and the individuals in these cases. ${ }^{10}$

Parallel to the growth of the German institutions and sites displaying remorse, their role and meaning within German contemporary culture at large have been discussed, more or less independently of their specific contents and character. In 1988, Martin Broszat raised a warning that through their reference to the fascist era, monuments "may not remember events as much as bury them altogether beneath layers of national myths and explanations." (Quoted inYoung 1993: 5) This was part of a wider discussion where Broszat argued that the time had come for the Germans to historicize and normalize their attitudes towards their National Socialist past. He drew heavy criticism for this position, and the renewed interest in building and organizing large museums of repentance may on one hand be interpreted as an argument in favor of the position that the time is not yet ripe for historization. The comment of Mary Fulbrook on an "obsessive concern with guilt and shame" which was displayed in a debate about the Holocaust Memorial in Berlin may be taken as a support of this view (Fulbrook 1999: 229). On the other hand, the scholarly approaches at the newest sites also bear witness to a kind of approach that manages to attend to the values without falling prey to

10 The description of Bergen Belsen and Neuengamme is based on the author's own visits at the premises in November 2007. 
shallow emotions. At all events, the question of how World War II is being presented within German museums and exhibitions has become a part of the much larger theme of the German struggle to make sense of its traumatic past.

Another value-based approach that might have been chosen in exhibitions is what may be called "the reconciliation approach". Reconciliation between earlier enemies has been an honorable aim for different kinds of institutions, probably the most famous being the South African Truth and Reconciliation Commission in the aftermath of the political changes in the country in 1994. Another institution based on reconciliation between former enemies is the Georg Eckert Institute of Textbook Research in Braunschweig, Germany, which was founded shortly after the Second World War with the explicit aim of defusing nationalism and reciprocal animosity by harmonizing the narratives in history textbooks from different nations.

In the museum world, a paradigmatic example of reconciliation as a goal may be the museum inaugurated in 1967 at the World War I battlefield of Verdun. Its explicit aim has not been to generate pride in the glory of the French army, but to promote understanding between the former enemies. ${ }^{11}$

History exhibitions aiming particularly at reconciliation are much more rare when considering Word War II. One main explanation for this is the fact that reconciliation demands a minimum of reciprocity between parts and a minimum of admittance on both sides that they may have something to regret. Opinions are very clear as to who bears the overwhelming guilt and blame for the war. Hardly any serious historian would object to this verdict. However, recently research has focused more extensively on themes like the allied air campaign against German cities and the Soviet army's harsh behavior during its advances on the Eastern front, but also in Poland and the Baltic states during the first year of the War. One might very well imagine that special exhibitions focusing on subjects like these may be curated under the banner of reconciliation. But then reconciliation cannot be separated from other feelings and attitudes, like admittance of guilt, remorse, repentance and forgiveness.

An example of the reconciliation approach may be the GermanRussian museum at Berlin-Karlshorst, which opened in 1994. From 1967 on, the building, where the armistice between Germany and the Soviet Union was signed in 1945, was the site of a Soviet army museum

11 http://memorial-de-verdun.fr/m-historique-et-missions.html, accessed 28/ 02/10. 
"for the Unconditional Surrender of Fascist Germany in the Great Patriotic War 1941-1945". ${ }^{12}$ After German unification and the fall of the Soviet regime plans began for a new museum, aiming at providing a common German-Russian interpretation of the war. The approach is lowkeyed and based on the idea that when facing unheard of amounts of terror and mass murder, one has to give the visitors some possibilities to distance themselves emotionally. Only from some distance the scale of the monstrousness may be grasped, the organizers maintain. (Jahn 1997: $11 \mathrm{pp}$.) In this way the museum clearly distances itself from a row of other institutions that deliberately seek to evoke emotional involvement, even immersion in individual fates.

Concepts like guilt and repentance are closely tied to religious attitudes. Religious expressions are not least visible at exhibitions commemorating the Holocaust, but also at other memorials focusing more generally on massive violations of human rights before and during the War. This approach, which is very common at Holocaust memorials, may be summarized by the words "remembrance and sorrow".

First and foremost in this category one finds institutions like Yad Vashem in Jerusalem and Auschwitz in Poland. In contrast to Auschwitz and other memorials built on the premises of the atrocities, Yad Vashem resembles the Holocaust Memorial in Washington DC by being situated a long distance away from where the atrocities were committed. Nevertheless Yad Vashem has become a model and source of inspiration for a large number of memorial sites and exhibitions, not only because of its early foundation in 1953, but also because of the solid base of research for its activities. Auschwitz has to be mentioned in this analysis, not only because of the scale of the atrocities that were committed there, but also because the very name has become emblematic of the Holocaust all over the world.

Institutions in this category do not only research and teach history in an academic sense of the word. A crucial aim is to invoke feelings and empathy with the victims as a means to produce and strengthen values and attitudes. A particular method of employing empathy may be found at the Holocaust Memorial in Washington, where visitors are equipped with an ID card of a victim, with whom they are supposed to identify and to connect emotionally. The method is not unique, as it has also been employed at the Flanders Field Museum at Ypres, where the subjects of identification are soldiers at the World War I battlefield (Lord 2007: 358). However, the method has been subject of discussion, and

12 http://www.museum-karlshorst.de/html/gebaude/aa/langtext.shtml, accessed 28/02/10. 
has not been replicated in a grand scale at other institutions (see also the contribution by Bjerg in this volume, on the relationship between evoking empathy, history education and history culture).

A further development of this approach is what may be called "The educative human rights-focused exhibition". Following a rapid increase in public as well as academic interest in human rights, new centers have sprung up. Here, displaying the history of the war is not an end in itself, but primarily a means to draw attention to and to illustrate more general principles of human rights. An example of this category is the Centre for Studies of Holocaust and Religious Minorities in Oslo, with an "explicit aim to be a meeting-place for people who want to participate in the enduring controversy concerning all kinds of religious, racist and ethnic motivated repression", as stated on the website of the center. ${ }^{13}$ Other Norwegian centers with pronounced profiles of linking human rights to Second World War experiences, are the Memorial and Human Rights Centre at the former concentration camp Falstad in Central Norway and "Stiftelsen Arkivet" (The Foundation the Archive), based in the former regional headquarters of the Gestapo in Kristiansand. The institution declares that

"[b]y promoting dialogue, historical reflection and communication among different generations, Stiftelsen Arkivet wants to assist in the achievement of human rights, human dignity, peace building and conflict prevention". ${ }^{14}$

In practice it is difficult to draw a clear line between these generally oriented centers and exhibitions with pronounced educational goals, e.g. at former concentration camps in Germany. Under all circumstances are they to be judged not only by virtue of their ability to communicate desired values, but also on whether they manage to uphold scholarly principles. The tendency of "universalization" can also be observed outside the museum world. See e.g. the contribution by Bjerg in this volume.

\section{Developments and challenges}

From this overview four main lines of development may be drawn:

- There is a clear development away from patriot grand narratives of hardship and victory towards more general, moral questions.

13 http://www.hlsenteret.no/English, accessed 10/23/08.

$14 \mathrm{http}: / /$ stiftelsen-arkivet.no/english, accessed 10/24/08. 
- War exhibitions based on material objects have to a large degree given way to concept-based exhibitions. Authentic war objects have to serve some communicative function to deserve being displayed.

- Exhibitions tend to be based on a more distinct scholarly approach at the expense of one-dimensional didactic narratives.

- Exhibitions are to an increasing degree being combined with other means of communication and learning.

These trends seem to be well in line with general trends in historical exhibitions. However, there are other trends in museum development that represent more profound challenges to how war should be exhibited.

On one side there has been a recent trend in some big museums to tune down the historical context of artifacts, emphasizing instead the objects themselves, particularly when aesthetically valuable. This is a very rare approach in war museums, not only because aesthetic properties as a rule are of minor importance compared to other properties of the objects connected to war, but also because war exhibitions invariably convey some form of message which demands explaining the contexts where artifacts have been produced, used or found.

Another challenge may be seen as an extension of post-modern tendencies to criticize grand narratives and what the British philosopher Beth Lord characterizes as "the heavily didactic displays of the past" (Lord 2007: 362). "Ideas of universal truths or single fixed histories are ideas that the best museums are trying to challenge", she maintains. "If the past is to be genuinely open, it cannot be presented as a fixed truth that can only be remembered" (Lord 2007: 358).

As opposed to the fixed way of telling history, Lord advocates a "general history" in Michel Foucault's sense, where the main methodical approach is examining particular artifacts or documents and developing how they fit into "multiple, discontinuous historical series. General history does not assume that all such documents will be evident for a single principle governing the time and place they are from, it takes their differences, specificities and discontinuities as primary", Lord writes. (2007: 362) She is preoccupied with changing the role of the objects in exhibitions, and her ideal is a museum where the object has become

"a living site of difference. It contains infinite differences and specificities to be opened up, related to other things and arranged in discontinuous series. The museum object is not the inert trace of a fixed past with which we can only connect through memory and empathy. Rather, in working with the object, in developing it into different causal series and multiple micro-histories, we will recognize the object as an integral part of what we are, and understand how 
these causal series have been the condition of possibility of present circumstances." (Lord 2007: 364-365)

However noble Lord's ideals may be of giving "power to both objects and visitors" by employing principles of general history, the ideals of "presenting history without narrative, without memory, and without empathy" (Lord 2007: 365) pose huge problems, epistemologically as well as ethically. An open-ended micro-historical approach to World War II would serve to confuse and complicate rather than clarify not only the explanations of what happened, but also the profound moral issues at stake.

Lord too seems to concede this. "Perhaps for many histories - the First and Second World Wars among them - it is too soon to treat them without reference to memory," she maintains rather inconclusively (Lord 2007: 366). An alternative view would rather state that it is not only "too soon", but also that for an indefinite future the war of the past neither is nor ought to be "genuinely open" and devoid of fixed truths. Avoiding dogma, there nevertheless are truths, e.g. about atrocities and genocide that are undeniable, and trying to present this history "without narrative, without memory, without empathy" would be untenable. The challenge is to find ways to combine empathy and moral engagement with scholarly discussion, multi-perspective approaches and an urge to pose, face, and explain even the most profound and disturbing questions.

The very best war museums have come a long way towards these goals. They also manage to take advantage of the main features of exhibitions as a medium, namely their three-dimensionality. A conscious spatiality and a successful employment of object-based narratives are the main arguments for choosing exhibitions as a means of communicating history. This means that one not only has to decide what to tell, but also how to tell it.

Another challenge stems from the meeting between the intentions of the curators of the museum and the visitors' memory, historical consciousness and expectations at large. "Although visitors may fully expect and desire to be educated, instructed, to learn 'something new', as soon as that knowledge conflicts with memory and experience, trouble begins", Susan Crane (2004: 322) maintains in a comment on the controversies about the Smithsonian's plans for a commemorative exhibition on the bomber Enola Gay, 50 years after it dropped the first atomic bomb on Hiroshima. The row demonstrated that important parts of the American public simply did not want to be confronted with inconvenient parts of the past. "The original Enola Gay exhibit, with its images of Hiroshima and Nagasaki bombing victims and artifacts from 
'ground zero', would have transgressed the bounds of acceptable American memory by emphasizing 'suffering caused"', Crane writes (2004: 329).

In short: Museums may aim at influencing historical consciousness and at creating more profound morally based understandings, but they have no control over the outcome of the meeting between the exhibitions and the expectations and prejudices of the public. 


\section{References}

Ambrose, Timothy/Paine, Crispin (eds.) (2006): Museum Basics, 2nd edition, Routledge, London/New York.

Bennett, Tony (1995): The Birth of the Museum, Routledge, London/New York.

Bordage, Roger (2007): "Sachsenhausen, a flawed museum”. In: Sheila Watson (ed.), Museums and their Communities, Routledge, London/New York, pp. 228-233.

Crane, Susan A. (2004): "Memory, Distortion and History in the Museum". In: Bettina Messias Carbonell (ed.), Museum Studies, WileyBlackwell, London/New York, pp. 318-334,

Dean, David (1996): Museum Exhibition. Theory and Practice, Routledge, London/New York.

Fulbrook, Mary (1999): German National Identity after the Holocaust, Polity Press, Cambridge.

Jahn, Peter (1997): "Gemeinsam mit den Schrecken erinnern: Das deutsch-russische Museum Berlin-Karlshorst”. In: Hans-Martin Hinz (ed.), Der Krieg und seine Museen, Campus, Frankfurt/New York, pp. 11-23.

Kaienburg, Hermann (1991): 'Vernichtung durch Arbeit'; der Fall Neuengamme, J.H.W. Dietz, Bonn.

Lord, Beth (2007): "From the document to the monument. Museums and the philosophy of history". In: Simon J. Knell/Suzanne MacLeod/Sheila Watson (eds.), Museum Revolutions, Routledge, London/New York, pp. 356-366.

Luke, Timothy W. (2007): "Nuclear Reactions: The (re)presentation of Hiroshima at the National Air and Space Museum". In: Sheila Watson (ed.), Museums and their Communities, Routledge, London/New York, pp. 197-212.

Prusakova, Alla Andrejewna (1997): "Das Zentralmuseum der Grossen Vaterländischen Krieges in Moskau”. In: Hans-Martin Hinz (ed.), Der Krieg und seine Museen, Campus, Frankfurt/New York, pp. 7387.

The Hiroshima Peace Memorial Museum (1999): The Spirit of Hiroshima, an Introduction to the Atomic Bomb Tragedy.

Walsh. Kevin (2007): "Collective Amnesia and the Meditation of Painful Pasts". In: Sheila Watson (ed.), Museums and their Communities, Routledge, London/New York, pp. 435-447.

Young, James E. (1993): The Texture of Memory, Yale University Press, New Haven. 


\title{
World War II at 24 Frames a Second - Scandinavian Examples
}

\author{
ULF ZANDER
}

World War II shows no sign of fading away. A large number of books and articles are still being published at the same time as memories of the war intermingle with present day politics. Events and processes that began before the outbreak of the war and had effects on Europe long after 1945 are, in many respects, still at the core of most, if not all, European politics. The Molotov-Ribbentrop Pact, the German-Soviet non-aggression agreement from August 1939, is a vivid example of a European Lieu de mémoire. It is, the German historian Stefan Troebst writes, one of several central points of a memory culture dealing with one of the greatest catastrophes in human history (2009: 249-256).

Despite, or perhaps because of, simplified divisions between credible historical research, on the one hand, and subjective memories, on the other, collective memory and memory culture have been concepts at the core of historical research during the last decades. One of the more ambitious attempts to define memory culture takes as its starting point the ongoing struggle between what is included and what is excluded from dominating narratives of the past. This is at the same time a construction of memories and a struggle for meaning. Seen in this way, collective memory is both an important part of a construction process which aims to find meaning in a chaotic diversity and an ideological conflict in which history is used in order to win advantages in the present or in the near future. Thus, memory is a narrative representation of the past oriented towards the future (Karlsson 1999: 48; Sundholm 2007: 115). Since film is such an important mediator of history, moving images give 
meaning at the same time as they are at the core in fierce ideological battles, not least when it comes to the Second World War.

The Molotov-Ribbentrop Pact is, like many other significant historical events, important in its own right, but we can hardly underestimate the importance of contemporary political life, which has effect on the mediation aspect. For decades, the secret protocol of the MolotovRibbentrop Pact, dividing Eastern and Northern Europe between Nazi Germany and Soviet Russia, remained unknown to the general public throughout Eastern Europe. But when it surfaced in the late 1980s, the new knowledge had a deep impact on the liberation movements in the Baltic States and in Poland. Thus, what we remember, or are allowed to remember, and what we forget depends to a large extent on the development of history cultures. A history culture can be studied both as a structure and as a process. When studying history culture as a process, it is the different ways of mediating history and their consequences which are of importance. When analyzing history culture as a structure, the focus is on differences between, for instance, countries. In a country like Sweden, which has been spared from war during a period of almost two hundred years and been a democracy for almost a hundred years, different attitudes and behaviors are to be found compared with dictatorships and/or war-torn countries. Such a conclusion by no means excludes differences within one country (Karlsson 2003: 30-38). A history culture can include dividing opinions both over time and in regard to one and the same product. With the filming of Väinö Linna's famous novel Tuntematon Sotilas (Unknown Soldier) as an example, John Sundholm (2007: 120-139) underlines striking differences in the reception of the version from 1955 compared to the one from 1985. While the first one soon became, as the novel, an icon for the Finnish war experience, the second one failed.

It is not surprising to find that the combination of war and film has been a viable one ever since the infancy of cinema. Thanks to films, wars and genocides can come to life and turn into a kind of assembly points for thoughts on and opinions about justified wars on the one hand and immoral and excessively violent assaults on the other. With the Jewish experience as an example, Paul Patera wrote in 1950 that film was the art which most easily prepared the public for "we" against "the others" generalizations. The tragedies of the Holocaust were a shocking proof of this. However, the increasing number of films dealing with the legacy of the Nazi genocide, which premiered in the late 1940s, showed that films could also be a forceful weapon in fighting the prevailing antiSemitism (Patera 1950: 149-159). 
Film and war are interdependent in a number of ways. Films became early on a sharp propaganda weapon, used in wars and conflicts, and thoroughly explored during the First World War. During the interwar period, the Soviet Union and Nazi Germany established strong links between government and film industry. Even power holders in the United States and Great Britain realized the importance of film propaganda, but left the primary responsibility for developing corresponding activities to the various studios. In addition, the wartime film production created, as it turned out, profitable employment. From an American point of view, war as depicted through films has been characterized as "a love affair", and the same goes for many other countries' film industries (Matelski/Street 2003: 3). An interesting conclusion is that films have had an impact during the wars, but even more so as "descriptions" of the war in hindsight, shaping the way we look on armed conflicts, then and now (cf. Paul 2003: 3). "Indeed", writes historian Michael Paris (2007: 2), "it might well be argued that the popular memory of the Second World War has always been shaped more by the moving image than by any other form of cultural transmission."

Since documentaries and, even more so, feature films occupy a central position in most historical cultures, many history producers use moving images for their purposes, not least when it comes to questions of war and peace. Among them we find almost every position from romantic nationalist to war-weary pacifist. Due to its great influence on millions of movie-goers, it has been a temptation to rewrite history in the cinemas so that past defeats become moral victories, war criminals become heroes, or vice versa (cf. Strübel 2002: 8-9). The historical revision on film has in some cases been very successful. Undoubtedly, the South lost the American Civil War, but the Southerners" "lost cause" has time after time undergone a transformation from a military and a political defeat to a bitter-sweet farewell to a culture which, although it is stained by the slavery issue, nevertheless deserves a belated revenge against the industrialists in the North.

The Scandinavian countries had very different war experiences. Denmark and Norway were invaded by German troops on April 9, 1940. The Danes capitulated the same day, and their government was allowed a certain amount of autonomy until 1943. In Norway, the fighting went on until resistance became impossible, when British forces had to leave the battlefield. While Vidkun Quisling led a puppet government, Norwegians in exile formed a government in London. Sweden succeeded in remaining neutral, although the neutrality was determined by the winds of war. After the outbreak of the war and in the following years, special consideration was shown for the powerful German neighbor, but in the 
last years of the war the demands of the Allies took priority. Considering this, one can say, as a starting point, that in all three countries the films, like history writing in general, show markedly different features.

While especially American, German, British, French and Soviet war films have been analyzed in international research in recent decades, the study of Scandinavian examples is still rare. However, the material basis for such an analysis is rich. It consists primarily of films and television series depicting aspects of the Second World War in the Scandinavian countries and the extensive press material, dealing both with the production and the reception of these history products. Of special interest are the Danish film Flammen og Citronen (Flame and Lemon, 2008), the Norwegian film Max Manus (Max Manus - Man of War, 2009), the Swedish television series Någonstans i Sverige (Somewhere in Sweden, 1973) and the Swedish film 1939 (1989). We will look at them as history cultural products that refer to the actual history of the Second World War. But it is most likely that their producers have worked even harder to capture the values of present society that prevailed during the period when the films and televisions series were produced. Seen in this way, films about the past always say more about the time when they were produced.

\section{Scandinavian cinema during World War II}

As in all other countries, film also played a vital role in Denmark, Norway and Sweden during the Second World War. In Norway, attempts were made to adapt the national film production to the "new orientation" that Quisling and his party Nasjonal Samling tried to impose on the Norwegian society. The result was meager, yielding only a few political films (Sørenssen 2007: 220-230). Also, the German censorship could not foresee all possible alternative interpretations of certain films. For instance, the importance of resisting occupiers was indeed occasionally depicted, especially in films with historic settings. Snapphanar (1942), a Swedish film about the fighting and, eventually, consensus between the Swedish army and the Danish guerrilla movement during the wars between Denmark and Sweden in the $17^{\text {th }}$ century took on a new meaning when it was shown in Denmark. To many Danish viewers, the Swedes from the old days could be seen as the Germans of today. The historic Danish guerrilla soldiers in the south of Sweden were forerunners of the resistance movement in wartime Denmark.

Danes and Norwegians who opposed the Germans lacked the opportunity to make their own movies. This did not mean that they were for- 
gotten. The genre of occupation and resistance soon became popular in Hollywood. The first of these films were released during the war. The American movie makers made quite an effort to cover a great deal of European geography. Settings for the occupation-and-resistance-genre were the Netherlands, Yugoslavia, Czechoslovakia, France and Norway. With few exceptions, the unity of the resistance fighters was praised, not least of those in Norway. The popularity of Norway in Hollywood can be explained with the actions of Vidkun Quisling. He became the personification of the fifth column which in the wake of the German attack betrayed the unsuspecting and peace-loving Norwegians. The other reason is that, once the German invasion was a fact, the Norwegians, despite hopeless odds, did actually fight tenaciously against the German army. Furthermore, King Haakon VII refused to surrender or support any form of German-friendly government. To the American public, Norway was, as President Roosevelt put it, "at once conquered and unconquerable" (McLaughlin/Parry 2006: 173-176).

In Sweden the film supply was also limited. Before the war, Swedish film distributors wanted to limit the import of films from Hollywood and cooperated to a certain extent with the German film industry. It has rightly been claimed that most representatives of Sweden's film industry did not support the racial and pro-Nazi political goals. Instead, they hoped to "side-step German propaganda efforts by steering clear of politically sensitive stances of any kind" (Wright 2007: 266). After the outbreak of the war, this proved easier said than done. The German Propaganda Ministry was especially until 1943 successful in persuading Swedish film distributors not to show films with anti-German messages. As a result, before the end of the war it was only in membership based film societies that it was possible to watch Leslie Howard's Pimpernel Smith (1940) or Charlie Chaplin's The Great Dictator (1941).

In the domestic film production, the will to preserve Swedish neutrality was a strong theme. A recurrent motive was Swedish soldiers standing guard along the Swedish coasts, ever ready to keep the looming threats at a safe distance. With Kadettkamrater (Cadet Comrades, 1939) as an example, film historian Jan Olsson stresses that this type of films were based upon "camaraderie and patriotism, it pays tribute to military life and its hardships as well as the military justice system" (1979: 7071).

Already in 1942, a critic of the Nazi regime could be seen on the silver screen. Rid $i$ natt! (Ride Tonight!) was a film adaptation of the famous author Vilhelm Moberg's controversial novel with the same title, which invited comparison between the aristocratic oppression of the peasants in the $17^{\text {th }}$ century and the ongoing German occupation of large 
parts of Europe. During the last war years, more allegories of the Nazi regime's brutality could be seen at the movie theatres. Other Swedish films discussed neutrality dilemmas and the concessions made by the Swedish government during its neutrality policy. However, the critical tone was rather short-lived. Symptomatically enough, it did not take long after the war for the soldier's life to again become the subject of fun and ridicule, especially in the Swedish equivalent of the good soldier Svejk, Soldat Bom (Soldier Bom, 1947), which also received some international attention (Liljefors/Zander 2003: 214).

\section{Memories of a war not fought - the Swedish perspective}

The shift did not mean that the well-proven guard theme disappeared from sight. One of the most popular novels in post-war Sweden was written by the author and journalist Jan Olof "Jolo" Olsson and dealt mostly with the Swedish soldiers who were on guard along the Swedish borders from the outbreak of the war 1939 until its end in the spring of 1945. Någonstans $i$ Sverige was made into a seven-part television series in the early 1970s. It starts with a familiar motive: a guard on his post in a wintry landscape. The nostalgic feeling was reinforced by the choice of the musical theme - Ulla Billquist's signature tune "Min Soldat" ("My Soldier"), a Swedish equivalent to Marlene Dietrich's "Lili Marlene" or Vera Lynne's "We'll Meet Again". During and in-between the exercises there are political debates, such as the Communist defense of the Soviet attack on Finland, while at the same time strong demands are heard for the deployment of Swedish soldiers to Finland.

Recently, a Swedish journalist concluded that Någonstans $i$ Sverige is to be seen as the way the radical generation of 1968 looked upon the war in the aftermath (Arnstad 2009: 159). Even though he does not present any real arguments for his point of view, there are scenes supporting his conclusion. For instance, a mild critique of the lack of Swedish willingness to go to war is presented early on, since it is obvious that many soldiers had never stood on skis before. The harshness of the first war winter is turned into hope of returning home, something which takes a dramatic turn when Germany attacks Denmark and Norway. Other aspects of the war which are commented are, for instance, the internment camps for Communists, the soldiers' difficulties in keeping their relationships with their women back home alive and the difficulties for the women on the home front. 
But the main theme in the television series is not radical critique. The willingness to support the by then dominating perspective of the "small state realism", meaning the realistic but not always consistent or morally righteous neutral policy which prevailed in Sweden between 1939 and 1945, is obvious in a scene with the German troop transports by rail to Norway through Sweden. The latter, widely discussed subject in Swedish postwar debate, is highlighted when a Swedish officer with sympathies for Germany complains that it has come to his knowledge that Swedish soldiers are armed and pointing their weapons at the Germans. He is also upset that a Swedish guard "salutes" the German soldiers with his fist. The problematic fact that German soldiers were allowed to travel on Swedish railways is neutralized when the commanding officer takes the soldier's side, ironically saying that he hopes that the German soldiers did not shit down their pants in fear. This comment is very much in line with a dominating viewpoint during the first postwar decades, claiming that Sweden, as a small country with a realistic policy towards the mighty Nazi Germany, in reality did not have any choice. This opinion is also supported in a regular reading of a wellknown photography, showing a Swedish soldier on high ground, pointing his rifle down at a large number of unarmed German soldiers. In fact, this picture was taken after the end of the war and depicts German prisoners of war, but has repeatedly been described as if it was from the early war years when the Swedes were in full control of the German transports (Liljefors/Zander 2003: 217-218).

When Swedish territory really comes under attack in the television series, when the Germans are retreating through northern Finland, the matter is quickly resolved thanks to a Swedish trademark: calm, reasoning and convincing argumentation. The peace is of course welcomed, and the soldiers promise to meet again, but the comradeship of the war years does not last.

The television series was eagerly anticipated. The selection of firstrate actors, ambitious attempts to recreate the environment of the war years as well as the use of period newsreel footage, which was inserted into the narrative, guaranteed quality. The Swedish soldiers could in a way be seen as a kind of counterpart to the elderly, confused and often inefficient grey guard in the British television comedy Dad's Army (1971). In both cases the war is ever-present but the main characters seldom or never come in direct contact with it. On the other hand, in the Swedish version the war is not only fun and games. It was, as writer Jan Olof Olsson and director Bengt Lagerkvist claimed, important to show the grey reality without any heroes and the contrast between the high 
command and the common men, who despite hard conditions eventually became good soldiers (Adrup 1973; Björkman, 1973).

When the first parts were broadcasted the men behind Någonstans $i$ Sverige received support from none less than the commander-in-chief of the Swedish army. He, like many others, had nodded in agreement in front of the television set: this was the way it had been (Sörensson 1973). Indeed, the television series became as popular as the novel and brought a breakthrough for several Swedish actors. In fact, Janne Carlsson became - and still is - known as "Loffe", the nickname of the soldier he played in the television series. Någonstans $i$ Sverige was, as director Lagerkvist emphasized, typically Swedish and he did not expect it to be exported to the neighboring countries since the Swedish neutrality policy had not always been regarded well there during the war (Nilsson 1973). Critical voices were also heard in Sweden. The television series, they argued, showed a mendacious, fudged and even pathetic picture, which carefully avoided any potentially charged political conflicts in favor of humor. However, such views were the exception. One of the critics noted that he was in the minority, since he was surrounded by people competing to come forward and share their memories from the war years (Fagerström 1974; Nilsson 1974).

An explanation for the popularity was that television series' depiction of the turbulent year 1939 seemed to reflect the economic crisis that was discussed in the early 1970s (Fabricius Hansen 1973). The author himself wrote that there were no reasons to look back upon the 1940s in a nostalgic way, but the popular culture of that time supported such a sentiment. And even though restraints and restrictions were much more severe then than during the early 1970s, it seemed to Jan Olof Olsson that a lot of Swedes thought that life was much easier back then, when the war was all around but not in our midst (Olsson 1974: 19, 44).

The connections between the outbreak of the war and contemporary crisis were even more obvious in the film 1939, which had its premiere at the $50^{\text {th }}$ anniversary in 1989 . In the late 1980 s and the early $1990 \mathrm{~s}$ Sweden, then ruled by the Social Democrats, came under a lot of domestic criticism, which included the (lack of) neutrality during the Second World War and the Cold War. In 1939, World War II from the Swedish horizon revolves around two women. The film deals mainly with their joys and worries, but it also includes Swedish military accidents, the German train transports through Sweden, the Norwegian resistance movement and conflicts between town and countryside.

The Swedish exclusion from the war is not as unproblematic in 1939 as in Någonstans i Sverige (Qvist 1990). During an exercise, one of the female characters says to her friend that it feels like there is not a war 
going on, like the Swedes are trying to hide from evil, probably in vain in the long run. But even if the film mirrored the debate, the response was not positive. It was praised for credible period features, but the prevailing verdicts were more in the style of "an anonymous harmless cavalcade" and "stacked anecdotes" better suited for television (Hjertén 1989; Schildt 1989; Schiller 1989). One of the few defenders was the former leader of the conservative party, Ulf Adelsohn, who praised the film. Not only did it give a trustworthy view of the life in the Sweden of 50 years ago, it also offered a perspective on how other countries looked upon Sweden during the war, which was useful to reflect upon since Sweden was about to negotiate membership in the European Union (Adelsohn 1989). However, not too many wanted to take part in the history lesson, and 1939 became a financial fiasco.

\section{The heritage of April 9}

"Do you remember April 9, 1940", the voice-over belonging to the resistance fighter Flamman (The Flame) rhetorically asks several times in the Danish film Flammen og Citronen. The German occupation is probably the most important historic event in both Denmark and Norway - in competition with the national sovereignty 1905 in the Norwegian case which also had a great impact in Sweden. In a comparison between the Scandinavian countries, the Danish historian Claus Bryld has emphasized the similarities in the postwar history writing. Although the different war experiences, he finds an emphasis of Nazi-skeptical attitudes before, during and after the war (Bryld 2007: 34). Beyond the similarities, the German occupations left their mark on Danish and Norwegian societies. Therefore, World War II have had a different and more important position in postwar Denmark and Norway than in Sweden, which after 1945 adopted neutrality "as a state of mind", to quote the Swedish historian Alf W. Johansson (1997: 170).

It did not take long before a "basic story" was prepared in Denmark and Norway. According to the Danish version, the Second World War and besattelsen (the German occupation of Denmark) were two distinct and different phenomena. Although Danes took part in the fighting on both German and Allied sides, it was the national events in Denmark which were the important ones. As in Norway, two periods became dominant: the first days of April and especially the German invasion on April 9, 1940, and the beginning of May 1945, when liberation came. Even though the enormously successful Danish television series Matador (1978) takes part during the years 1929-47, the events during the 
war are of special significance in the story of the transition of Denmark from a class society to a welfare state, based upon egalitarian principles. Indeed, there are a few examples of Danish collaborators and traitors in Matador. Instead, it is either active or passive resistance against "them", the vaguely portrayed German occupants, which is highlighted. Matador also follows a main theme in postwar Danish historical culture. The efforts to save the Jews in October 1943 are seen as the ultimate proof that resistance was widespread (cf. Grubb/Hemmersam/Jørgensen 1995: 6172). There are numerous examples of this "provincial" way of discussing the war in Denmark as well as in Norway. It has maintained a strong position, mainly because both countries more or less indirectly belonged to the victorious Allied side (Bryld/Warring 1998: 41-42).

More films set during the war were produced in Norway than in Denmark, but regardless of the fact that the war looked very different in the two countries the films showed strong thematic similarities. With production starting during the last year of the occupation, films on the resistance movement were produced at irregular intervals in Denmark, in some early cases with illegal sequences from the war years. It was emphasized that the early films were authentic, capturing sabotage operations, interviews with traitors and with scenes from underground weapons factories. More often than not the "good" Danes were seen in the role of David, armed with old and primitive weapons, in a heroic, strong-willed and intelligent fight against the Goliath Nazi oppressors and their Danish allies. Many of the films illustrated the consensus view, which was the result of the compromise characterizing the composition of the liberation government of 1945. Moreover, from the 1970s onwards the focus on resistance fighters was supplemented with films on the rescue of the Danish Jews to Sweden in October 1943 (Stræde 2004: 123-142; Voilladsen 2000: 5-27). The documentary Det galder din frihed (1946) was a mixture of "dramatic reality" and "lyrical moods", wrote one of its supporters (Roos 1945: 16-17). Claiming authenticity and documentary truthfulness, this particular film did not exclude a sharp criticism of Danish foreign policy leading up to the outbreak of the war in 1940 and of the marked willingness among Danish politicians to cooperate with the German occupants. Therefore, the role of heroes was given only to the resistance fighters. Such a challenge to the consensusoriented historiography resulted, not surprisingly, in an emotional and passionate debate (Hemmersam/Nielsen 2009: 92-93).

Another example of a film which caused Danish debate was the Swedish television drama documentary Jane Horney (1985). According to the official version told by the Danish resistance movement, Jane Horney had been a beautiful but dangerous Swedish woman based in 
Copenhagen, who had to be eliminated because she was a German spy. The television series drew another picture. Jane had not reported to the Gestapo but to the Swedish police. Among the shady activities she learned about, the so called traitor's route between Denmark and Sweden was the most compromising. The route was jointly operated by the non-Communist part of the Danish resistance movement and the Germans in order to prevent Communist activities in Denmark after the end of the war. It was the fact that Horney learned about this route which was the actual reason for her being killed by resistance fighters, the film producers claimed (Leopold 1985). That this was controversial history writing became obvious in connection with the $40^{\text {th }}$ anniversary of the end of the war in 1985. The remaining resistance fighters attacked the film producers and the Danish television, whose management had bought the television series and planned to broadcast it. The opponents to Jane Horney did not succeed in banning the television series altogether, but due to their protests its broadcast in Denmark was postponed for a few weeks (Ahnfeldt-Mollerup 1993: 65-85).

One resistance fighter, who twice had orders to kill Jane Horney but failed to do so, was Bent Farschou-Hvid. He and his closest companion Jørgen Haagen Schmidt were better known under their alias, Flammen (The Flame) and Citronen (The Citron). They are the protagonists in the latest example of the Danish resistance film genre, Flammen og Citronen from 2008, already mentioned above. Both of them are at the centre of the resistance group Holger Danske, named after a mythical Danish king who according to the legend is said to be sleeping but who is always prepared to wake up and save his country when it is under attack. The resistance fighters took part in a number of sabotage operations and executed a dozen Nazi-friendly Danes. However, in the process, Flammen and Citronen become involved in disputes within the resistance movement and are used to eliminate persons suspected of being able to testify against Danes in high positions about their collaboration with influential Germans. With this plot, the film actually kills two birds with one stone. On the one hand, the film audience becomes aware of the debate which has been going on in Denmark during the last decade, in which criticism has been raised against some of the executions that resistance fighters were responsible for. It is also, on the other hand, obvious that the two main characters in the film are tricked by the resistance leader - who has personal reasons for concealing some compromising dealings with the Germans - into shooting innocent Danes and Germans, thereby saving their heroic status both in Danish history and in Flammen og Citronen. 
Like many other Second World War films from later years, the director and the writer of the script of Flammen og Citronen combine the more traditional war epic with elements of the Holocaust. In a key scene, the Flame's girlfriend asks him why he kills Nazis. He answers that his father sent him to Germany in 1940. At the hotel where he worked was a Jewish woman who had escaped detection. One day she is exposed and half beaten to death. The Flame does not respond directly to the additional question whether the Jewish woman had been his girlfriend, but his reaction reveals that this was indeed the case. Her destiny during the Nazi persecutions gives him the reason to fight, if necessary to the death. And to the death it is. Both the Flame and the Citron perish during the resistance struggle, but their memory lives.

Flammen og Citronen is the most expensive Danish film production to date. It also attracted a large number of moviegoers and led to interviews with old resistance fighters and increased attention for museum exhibitions about the occupation. The critics' response was mixed, praising both director Ole Christian Madsen and the leading actors, Thure Lindhardt and Mads Mikkelsen, but also complaining that the film was closer to a gangster drama than a war film (Skotte 2008). Others found it to be a nuanced and somewhat critical perspective on the resistance movement, saying it was "sober and serious" (Iversen 2008). Some voices criticizing a lack of historical correctness were heard, but equally interesting was that the film attracted much interest but sparked little debate, as a Swedish journalist noted (Söderberg 2008).

April 9 was also an important date in Norway, especially with the fighting there during the ensuing weeks as well as the resistance struggle after the German army established control over the country. A famous part of the struggle was the commando raid against the German heavy water-plant, immortalized in the Norwegian film Kampen om tungtvannet (The Fight over the Heavy Water, 1948) and The Heroes of Telemark (1965), starring Kirk Douglas. Even if films, as other history production, mainly mediated a heroic version of resistance and unity, there were some exceptions such as I slik en natt (In Such a Night, 1958) and Over grensen (Across the Border, 1980), dealing with Norwegian collaboration and anti-Semitism (Bruland 2004: 458-460; Vibe 1977: 117-126).

The latest addition to the genre, Max Manus, however, looks more like the resistance classic Ni liv (Nine Lives, 1957). In both cases the focus is on the harsh life of the resistance fighter. A telling example is the German ship "Donau". In the film, Manus and his comrades sink the ship because it is used to transport German soldiers. In modern Norwegian history culture, "Donau" is also synonymous with the deportation 
of the Norwegian Jews. Neither this, nor any other aspect of the Holocaust is included in the film.

Max Manus is based on the life of the resistance fighter of the same name. In the accompanying book Max Manus. Film og virkelighet (Nordseth-Tiller/Moland 2008), it is obvious that the film team wanted to get as close to a traditional scholarly historical ideal, to "the true story" as possible. However, film makers usually have to concede to other priorities. Instead of capturing the multitude and diversity of "the actual past", they have concentrated on dramaturgical aspects, making the story efficient and trustworthy in its own right (Zander 2006a: 14-22).

\section{Picture 1: Scene from Max Manus}

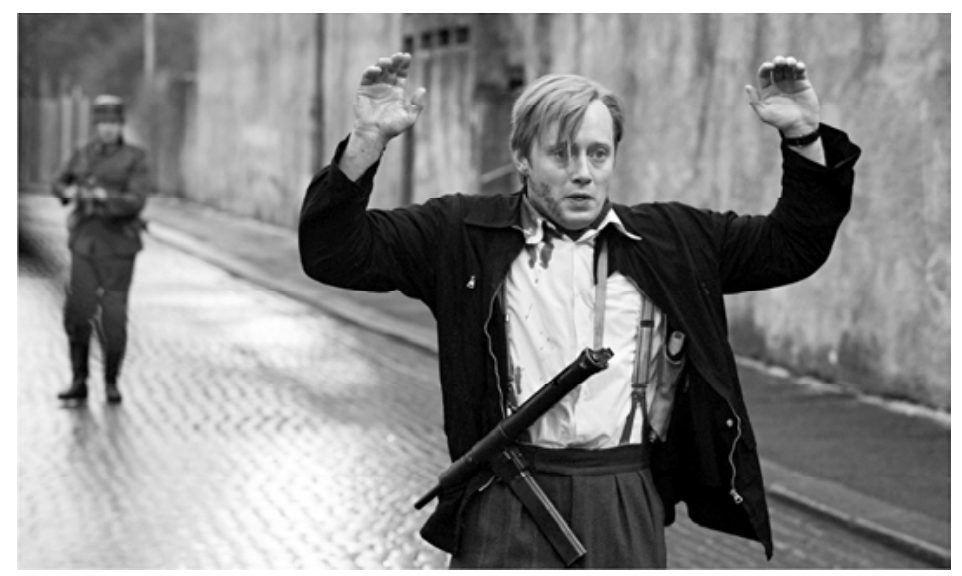

Photo credit: Filmkameratene

That the result was doomed to be subjective, no matter how many facts it was based on, was something that Norwegian film critic Jon Selås (2008) was aware of. With the exception of the soundtrack, he found that the film makers had handled this subjectivity in the best possible manner. The film could, he stated, function as a reminder to the Norwegian youngsters of today of all the suffering and sacrifices that the Second World War generation had to put up with in order to create the modern Norway. Other critics concurred in the chorus of praise and predicted hundreds of thousands of Norwegian moviegoers. Among the supporters, some claimed that Max Manus was the best Norwegian film ever made, and that Aksel Hennie's performance in the leading role was outstanding (Olsen 2008; Steinkjer 2008). Other critics, who were generally positive, raised critical remarks. The film, they said, was very traditional and conservative and would most probably raise a debate (Alver 2008; Haddal 2008). In this they were right; Max Manus is one of the 
most successful Norwegian films in decades. But not everyone liked what they saw. The writer Erling Fossen (2008) reacted against what he saw as yet another example of glorification of a resistance movement. His article met with harsh criticism, not least from former resistance fighters. One of them went so far as to call Fossen's article an example of an argumentation typical of the Nasjonal Samling (Sønsteby 2008).

When Max Manus had its Swedish premiere a few critics supported the Norwegian praise. Most were, however, less favorable. Too few choices had been made, it was claimed, and therefore too many persons, places and events had been introduced. Furthermore, the mixture of genres was considered problematic: the film was a psychological drama, an action thriller and a romantic story rolled into one (Janson 2009). Another recurrent remark was that, more than anything, Max Manus reminded one of an adventure book for boys, painted in moral black and white and without psychological depth or historical complexity (Aghed 2009; Andersson 2009: 51-52).

\section{Films and World War II}

In many synthesizing historical works of the past century there have been two recurring characteristics: war, terror and genocide on one hand, the emergence of welfare states and technological development on the other. Among the latter, film made a great breakthrough early on and has been one of the most, probably the most, influential history mediator during the last hundred years. One explanation for the filmic domination is that moving images are often pluralistic. Another is that films, more than other media, appeal to the onlookers' emotions and their understandings of good and bad, white and black. In this process, the differences between imagination and reality, facts and fiction, tend to be blurred even while the films' message can be clear, unambiguous and convincing. Thus, films and television series can - and have repeatedly done so - contribute to focusing on suppressed historical misdeeds, often when the history cultural conditions have been in favor of change. For instance, the television series Roots (1977) and Holocaust (1978), with their critical approach towards slavery and the Holocaust as well as the prolonged silence about these events, were produced after a decade of harsh criticism against traditional values and history writing in the aftermath of the Vietnam War and the Watergate scandal in the United States. But the opposite is also the case. Most moviegoers are reluctant to be challenged. Instead, they want that their beliefs to be confirmed as "truths". The result is, in the worst-case scenario, that established histor- 
ical interpretations are cemented and cannot be supplemented or replaced. A consequence of this slow movement is that, in order to attract as many people as possible, commercial films must include values and interpretations which are as broad and inclusive as possible. If there are few incitements in the history culture at large to confronting prevailing interpretations, this will most likely produce few filmic efforts to challenge historical master narratives (Zander 2006a).

Among the Scandinavian films dealing with the Second World War, both reactions against prevailing perspectives and defenses of old-time national identities based on heroic fights against the German enemy are to be found. The Danish Flammen og Citronen is an example of a film which contains references to the Holocaust, a celebration of the resistance movement but also critique of the same, all in one. The result was a commercially successful history product, not least because both contained justifications of what happened 1940-45 as well as challenges of "old truths" of this era. Max Manus is a more simplistic film, reflecting reluctance in Norwegian public life to revaluate the national understanding of the Second World War.

In contrast to Denmark and Norway, the public debate in Sweden about World War II have had its centre in public life, and not in the specialized historical journals (Bryld 2007: 44). Thus, the lack of Swedish films on the Second World War and the mostly negative Swedish response to Max Manus does not mean that there is no interest in the years 1939-45 in Sweden. Debates about World War II have raged in recent decades in all three Scandinavian countries. Strong criticism has been put forward against what have been perceived as simplifications and idealizations. But as the Swedish example shows, fundamental changes do not come easy. It is clear that concepts such as neutrality, resistance and domestic consensus are concepts that still hold huge attraction, and challenges against them still tend to result in backlashes or to inclusion of critical aspects - in order to neutralize them - into the dominating national story (Zander 2006b: 368-374). As long as this is the case, the films will most likely continue to reflect such opinions.

\section{References}

Adelsohn, Ulf (1989): ““1939’ ger oss rätt EG-perspektiv”. In: Dagens Nyheter, December 27.

Adrup, K. A. (1973): "Fem förlorade år för tusentals vanliga grabbar". In: Dagens Nyheter, June 3. 
Aghed, Jan (2009): “Norska partisaner i påkostat pojkboksäventyr". In: Sydsvenska Dagbladet, May 15.

Ahnfeldt-Mollerup, Eline (1993): "Historien som nyhed - den offentlige debat om Jane Horney-serien”. In: Claus Ladegaard (ed.), Når medierne spinder historiens tråd, Akademisk Forlag, Copenhagen, pp. $65-85$..

Alver, Eirik (2008): “Garanterat kassasuksess”. In: Dagbladet, December 18 .

Andersson, Gunder (2009): “Max Manus”. In: Filmrutan, Nr 2.

Arnstad, Henrik (2009): Skyldig till skuld. En europeisk resa i Nazitysklands skugga, Stockholm.

Björkman, Leif (1973): "Någonstans i Sverige - en serie om beredskapsåren”. In: Expressen, December 21.

Bruland, Bjarte (2004): "Wie sich erinnern? Norwegen und der Krieg". In: Monika Flacke (ed.), Mythen der Nationen. 1945 - Arena der Erinnerungen, Band 1, Verlag Philipp von Zaber, Berlin, pp. $453-$ 480.

Bryld, Claus/Warring, Anette (1998): Besættelsetiden som kollektiv erindring. Historie- og traditionsforvaltning af krig og besættelse 1945-1997, Roskilde universitetsforlag, Fredriksberg.

Bryld, Claus (2007): "Skandinaviske dilemmaer: Den nye fortelling om Anden Verdenskrig i Danmark, Sverige og Norge. En komparation”. In: Claus B. Christensen/Anette Warring (eds.), Finland og Danmark: Krig og besættelse 1939-45, Roskilde universitetsforlag, Fredriksberg.

Fabricius Hansen, Björn (1973): “Omruskning - 39”. In: Svenska Dagbladet, December 27.

Fagerström, Allan (1974): "Skammens tid - är det något att minnas?". In: Aftonbladet, January 8.

Fossen, Erling (2008): "Motstand glorifiseres". In: Aftenposten, December 13.

Grubb, Ulrik/Hemmersam, Karl-Johann/Jørgensen, Jørgen Riskær (1995): Matador - og vor egen tid, Copenhagen.

Haddal, Per (2008): “Flott, men friksjonsfri”. In: Aftenposten, December 17.

Hemmersam, Karl-Johann/Nielsen, Carsten Tage (2009): "Historiefortælling på film og i tv". In: Peder Wiben (ed.), Historiedidaktik, Colombus, Copenhagen, pp. 85-100.

Hjertén, Hanserik (1989): “Anonym, ofarlig kavalkad". In: Dagens Nyheter, December 27.

Iversen, Ebbe (2008): “Anmeldelse: idealisme og kynisme”. In: Berlingske Tidende. March 27. 
Janson, Malena (2009): "Krigsdrama utan fokus". In: Svenska Dagbladet, May 15.

Johansson, Alf W. (1997): "Neutrality and Modernity. The Second World War and Sweden's National Identity". In: Stig Ekman/Nils Edling (eds.), War Experience, Self Image and National Identity. The Second World War as Myth and History Gidlunds Förlag, Stockholm, pp.163-185.

Karlsson, Klas-Göran (1999): Historia som vapen. Historiebruk och Sovjetunionens upplösning 1985-1995, Stockholm.

Karlsson, Klas-Göran (2003): "The Holocaust as a Problem of Historical Culture”. In: Klas-Göran Karlsson/Ulf Zander (eds.), Echoes of the Holocaust. Historical Cultures in Contemporary Europe, Nordic Academic Press, Lund, pp 9-57.

Leopold, Anders (1985): “Nazistsamarbetet - Danmarks skam”. In: Expressen, October 21.

Liljefors, Max/Zander, Ulf (2003): "Det neutrala landet Ingenstans. Bilder av andra världskriget och den svenska utopin”. In: Scandia Historisk tidskrift 69:2, pp. 209-242.

Matelski, Marilyn/Street, Nancy Lynch (2003): “Introduction”. In: Marilyn Matelski/Nancy Lynch Street (eds.), War and Film in America. Historical and Critical Essays, McFarland \& Company, Jefferson, North Carolina \& London, pp. 3-12.

McLaughlin, Robert L./Parry, Sally E. (2006): We'll Always Have the Movies. American Cinema during World War II, The University Press of Kentucky, Lexington, Kentucky.

Nilsson, Lennart (1973): “Någonstans i Sverige’ ny TV-serie” . In: Dagens Nyheter, March 1.

Nilsson, Macke (1974): “NNågonstans i Sverige' ljuger om beredskapen". In: Aftonbladet, January 6.

Nordseth-Tiller, Thomas/Moland, Arnfinn (2008): Max Manus. Film og virkelighet, Oslo.

Olsen, Geir Jardar (2008): “Tidenes beste norske film”, In: www.tv2underholdning.no, December 17.

Olsson, Jan (1979): Svensk spelfilm under andra världskriget, Liber, Lund.

Olsson, Jan Olof (1974): “40-talet - är vi där igen?”. In: VeckoJournalen, $\mathrm{Nr} 1$.

Paris, Michael (2007): “Introduction”. In: Michael Paris (ed.), Repicturing the Second World War. Representations in Film and Television, Houndmills, Basingstoke, pp. 1-11.

Patera, Paul (1950): “Judiskt öde på vita duken”. In: Biografbladet, Nr 3. 
Paul, Gerhard (2003): "Krieg und Film im 20. Jahrhundert. Historische Skizze und metodologische Überlegungen". In: Berhard Chiari/Mattias Rogg/Wolfgang Schmidt (eds.), Krieg und Militär im Film des 20. Jahrhunderts, Oldenbourg Wissenschaftsverlag, München, pp. 3-76.

Qvist, Per Olov (1990): "Folkhemmets sönderfall. 1989 ser tillbaka på 1939”. In: Filmhäftet, Nr 1-2.

Roos, Karl (1945): "Filmen og Frihedskampen". In: Biografbladet, Nr 4. Schildt, Jurgen (1989): "Inget för kalkonjägarna". In: Aftonbladet, December 26.

Schiller, Hans (1989): “Storsatsningen '1939': En serie staplade anekdoter”. In: Svenska Dagbladet, December 27.

Selås, Jon (2008): "Stor 'Max Manus"”. In: Verdens Gang, December 18.

Skotte, Kim (2008): "Flammen \& Citronen er en voldsom film med ridser i lakken". In: Politiken, March 27.

Steinkjer, Mode (2008): "Max effektiv Manus-film”. In: Dagsavisen, December 17.

Strübel, Michael (2002): "Vorwort". In: Michael Strübel (ed.), Film und Krieg. Die Inszenierung von Politik zwischen Apologetik und Apokalypse, Leske + Budrich, Opladen.

Stræde, Therkel (2004): "Dänemark. Die schwierige Erinnerung an Kollaboration und Widerstand". In: Monika Flacke (ed.), Mythen der Nationen. 1945 - Arena der Erinnerungen, Band 1, Verlag Philipp von Zaber, Berlin, pp. 123-150.

Sundholm, John (2007): “'The Unknown Soldier': Film as a Founding Trauma and National Monument". In: Conny Mithander/John Sundholm/Maria Holmgren Troy (eds.), Collective Traumas. Memories of War and Conflict in Twentieth-Century Europe, Peter Lang, Brussels, pp. 111-142.

Söderberg, Staffan (2008): "Besættelsen i nytt ljus". In: Sydsvenska Dagbladet, April 8.

Sønsteby, Gunnar (2008): “NS-argumentasjon”. In: Aftenposten, December 16.

Sörenson, Elisabeth (1973): “Arméchefen om 'Någonstans i Sverige': En nyttig serie som erinrar om hur förhållandena var då”. In: Svenska Dagbladet, December 31.

Sørenssen, Bjørn (2007): "From Will to Reality - Norwegian Film during the Nazi Occupation, 1940-45". In: Roel Vande Winkel/David Welch (eds.), Cinema and the Swastika. The International Expansion of Third Reich Cinema, Houndmills, Basingstoke, pp. 220-231. 
Troebst, Stefan (2009): "Der 23. August 1939. Ein europäischer Lieu de mémoire?". In: Osteuropa 7-8.

Vibe, Nils (1977): Filmen i Norge etter krigen. Historikk og innholdsanalyse, Stavanger.

Villedsen, Ebbe (2000): "Besættelsebilleder. Den tyske okkupation som teme i danske spillefilm”. In: Kosmorama, Nr 226.

Wright, Rochelle (2007): "Swedish Film and Germany, 1933-45". In: Roel Vande Winkel/David Welch (eds.), Cinema and the Swastika. The International Expansion of Third Reich Cinema, Houndmills, Basingstoke.

Zander, Ulf (2006a): Clio på bio. Om amerikansk film, historia och identitet, Lund.

Zander, Ulf (2006b): "To Rescue or be Rescued. The Liberation of Bergen-Belsen and the White Buses in British and Swedish Historical Cultures”. In: Klas-Göran Karlsson/Ulf Zander (eds.), The Holocaust - Post-War Battlefields. Genocide as Historical Culture, Sekel Bokförlag, Malmö pp. 343-383. 



\section{Historical Propaganda and New Popular Cultural Medial Expressions}

\section{ERIK THORSTENSEN}

In connection with an exhibition about Leni Riefenstahl in the period 12th of September to 26th of October 2008, the Center for Studies of Holocaust and Religious Minorities (HL-senteret) in Oslo, Norway, tried out a teaching structure based on ideas of reflective historical consciousness. The pedagogical intention was to let the students/pupils explore the historical embeddedness of propaganda and thereby analyze the constructions of insiders and outsiders within propaganda by deconstructing the images and texts. The concept of historical consciousness and its three different levels are elaborated in Körber's essay in this volume. The target group was 14 to 16 years pupils from the Oslo area who visited the centre for one full day. ${ }^{1}$

The pedagogical goal was to enable the pupils to work in different ways of relating to history as developed through the concept of historical consciousness by Jörn Rüsen and others. We attempted to design the assignments given to the pupils in such a way that they would work either on the past, on history or on the present/the future - in either a reconstructive or deconstructive mode. These concepts will be presented in depth later on.

1 In addition to the visits of pupils at the centre, we also organized two teacher training courses - one for teachers with pupils aged 13-16 and one for teachers with students aged 16-19. The last-mentioned course was arranged so that there was a research conference the following day. The aim of these courses was how to use popular cultural expressions in teaching history, arts, Norwegian language, and social sciences. 
In this article I will describe the pupils' stay at the centre and how the day was organized, thereafter the background of this concept, and at the end I will present my evaluation of the pedagogical program through an analysis of the pupils' presentations.

The present study is an evaluation of how the pupils related to and learnt from history. Our goal was to use the specific genre of propaganda and narrative features in general as a prism for the pupils to explore the past. The narrative features explored were the differences between an active in-group ("us") and a passive or threatening out-group ("the others"). The final products presented by the pupils served as the basis for the evaluation of whether they were able to create and communicate their understanding of the past through analysis of narrative structures.

This article will be looking at the ways in which the students interpreted narratives of the past and discuss them to decide to what degree the teaching exercise was successful.

\section{The program of the visit}

The exhibition The Myth of Leni Riefenstahl was shown partly at HLsenteret and partly at the Norwegian Film Institute for a brief period of time during autumn 2008 in Oslo, Norway. The HL-senteret entered into a partnership with the municipality of Oslo in order to develop a framework which could convey the content of the exhibition to 14-16-year old pupils. This exhibition was the first one ever made on the theme of Leni Riefenstahl's life and productions which was not controlled by Leni Riefenstahl herself.

In practical terms, the visit of the pupils was organized as follows: First the pupils were guided through the permanent exhibition of HLsenteret and the Leni Riefenstahl-exhibition. During this guided tour, the pupils were shown examples of propaganda and the concept of popular culture was introduced. ${ }^{2}$ Here we would use posters showing either the

2 The notion of "popular culture" also has its historicity (as does the notion of propaganda). We did not try to establish any definition of "popular culture" with the pupils. Rather, we tried to provide examples and explain though these examples. As for the term itself, it is obviously meant as an opposition to "elite culture" or "high culture". I would here suggest a sketchy definition that relates the term "popular culture" to 1) the rate of reproduction of the phenomenon, 2) consequently to the lack of dispute amongst its public as to what is original and what is a copy, 3) the diffusion, and 4) its ephemerality - it is not intended to last even though (or because) it is spread everywhere. Propaganda is addressed later. 
French General Dreyfus portrayed as a snake and traitor as an example of propaganda, or German children's books depicting Jews as subhumans or as a threat to the pure people's community as examples of both popular culture and propaganda in popular culture. In order to place the exhibition in a historical narrative and to help the pupils in their work on and in the exhibition, we gave a 45-minute lecture introducing the distinction between "us and the others". Here, we used Tintin in Congo (1931/1946), Nazi election posters and propaganda posters, Stalin area posters, Khmer Rouge posters, and selections from Donald Duck, as well as Rambo and 24. Examples which all clearly implied who or what is represented as the ideal and who is seen as subordinate. These examples and the tour in the exhibitions made up the basis for our presentation. Here we addressed the issue of how the assumed recipients of the message where made to identify themselves with the producers of the different pieces of propaganda. The need to create a sharp division between "us and the others" was also elaborated towards finding some propagandistic-political message - and this was in turn used in the exercises.

There are huge differences between the language of medial expressions in the 1930s and 40s and today. In displaying examples of the formal rules of expression within that particular historical period, we aimed at liberating the (Nazi) content from the typical aesthetics of the period where the fit male was used as a symbol of the fit nation or the healthy people. In this way we hoped to pave the way for an easier access to the historical topic by removing some of the pupils' preconceptions about Nazi Germany as some a-historical entity. Thus we decided to show the cultural context in which Nazi aesthetics existed. This was done by showing Communist posters and posters for the Maccabiah Games in the 1930s. ${ }^{3}$

The integration of modern popular cultural expressions - and especially examples from movies, videogames, and TV after 9/11 - made up large parts of the continuing lecture. The examples were used to make the students discover what we mean with "propaganda and (new) popular culture".

In the presentation we drew upon classical narrative competence, i.e. who is the narrator, how are the different protagonists portrayed in the movie (and how are their opponents portrayed). Our main aim was to investigate how the others are depicted in modern popular cultural expressions and which - or how cultural codes are used in order to render

3 The Maccabiah Games are an international Jewish athletic event similar to the Olympics, held in Israel every four years under the auspices of the Maccabi Federation. 
(violent and degrading) action legitimate. The pupils were shown film clips from Rambo 3 and 24. In Rambo 3, the US soldier does not succumb to torture, while Jack Bauer in 24 is a torturer himself committing these acts in order to save US citizens. In Rambo 3 the bad guys are using torture - and it does not work, while in 24 it is the good guys who are the tortureres - and it works! The obvious points are: To show the change in the means the good guys resort to; to show that torture is a crime; to show that in propaganda the hero is never wrong; and that in popular culture it is the main protagonist's moral dilemmas that are addressed - there are seldom shifts in narrative perspective which would make the character's other sides visible.

\section{Exercises}

After this elaborate introduction the pupils were given exercises on three different levels.

1. Analysis of historical propaganda from the Mythos Leni Riefenstahl and the permanent exhibition.

2. The history of Leni Riefenstahl; create a biography where she is good and another where she is evil.

3. Ironic production of propaganda for contemporary use.

The students could use different types of media in working towards their presentation. They could draw posters; make movies or radio; create a PowerPoint, a collection of pictures; or other ICT-based presentations.

The pupils' presentations were held in a plenary session with their teachers present. The main objective here was to see how they interpreted the past, and ask them questions concerning their products relating to both the past, history, or present/future and following up both the reconstructive and the deconstructive mode and to the genre. Below I shall elaborate on the didactical concepts and ideas forming the background for the exercises presented here.

\section{Pedagogical background and ideas}

The construction of this didactic framework took as a point of departure the insight that 'research has shown that the pupils' historical consciousness is not primarily created at school, but rather at home through 
contact with movies, books, and games". ${ }^{4}$ We accepted this insight and started looking at popular movies, TV-series, cartoons, computer games in order to find out what the products forming and influencing the pupils might be. We then proceeded to collect examples from different popular cultural forms of expression which could make up the context of propaganda in and through the media in which we wanted to present the work of Leni Riefenstahl.

Furthermore, we followed Jörn Rüsen's understanding of what constitutes an historical narrative:

"The general competence concerned with 'making sense of the past' can be divided into three sub-competencies. These can best be defined in terms of the three elements which together constitute a historical narrative: form, content and function. With respect to the content, one can speak of the competence for 'historical experience;' with respect to form, the 'competence for historical interpretation;' and with respect to the function, the 'competence for historical orientation.'” (Rüsen 2004: 69).

The lecture and the tour of the exhibitions were thought of as moving towards content and form of the historical narratives. There could have been alternatives to such a lecture, i.e. that the pupils worked on the topics of propaganda in and through the media before arriving at the centre, but from experience we know that this can be a great threat to the overall success if the preparations are not carried out. Since the main objective in our work with the pupils was concerned with historical orientation and consequently with contemporary and future orientation, we wanted to leave it to the pupils to discover the functioning of propaganda through their own work in the exhibitions and to discuss the functions further during and after the pupils' presentations of their exercises. Therefore the main focus in the lecture needed to be questions of form and content in order to leave the function to be discovered by the pupils.

The different exercises correspond to work on three different levels: Past, History and Present/Future (see also Körber's contribution in this volume where the six-field matrix is developed). We tried to translate the different foci from Körber's didactical insights into assignments. Our choices when it comes to such a translation were:

4 Original: "Forskning har visat att elevers historiemedvetande i första hand inte skapas i skolan, utan i hemmet genom kontakt med filmer, böcker och spel.” (Hägelmark \& Johansson 2007: 17). 
Table 1: The exercises analyzed from the theoretical methodical competences

\begin{tabular}{|l|l|l|l|}
\hline Exercise & $\begin{array}{l}\text { Historical } \\
\text { orientation }\end{array}$ & Re-construction & De-construction \\
\hline $\begin{array}{l}\text { 1. Analysis of } \\
\text { historical propa- } \\
\text { ganda from the } \\
\text { Mythos Leni } \\
\text { Riefenstahl and } \\
\text { the permanent } \\
\text { exhibition. }\end{array}$ & $\begin{array}{l}\text { Focus "past" } \\
\text { of the past. }\end{array}$ & $\begin{array}{l}\text { Establish how } \\
\text { propaganda was } \\
\text { used. }\end{array}$ & $\begin{array}{l}\text { Go through the } \\
\text { narrative of the } \\
\text { exhibitions with } \\
\text { the aim to identi- } \\
\text { fy historical } \\
\text { propaganda. }\end{array}$ \\
\hline $\begin{array}{l}\text { 2. The history of } \\
\text { Leni Riefenstahl } \\
\text { - create one bi- } \\
\text { ography where } \\
\text { she is good and } \\
\text { another where } \\
\text { she is evil. }\end{array}$ & $\begin{array}{l}\text { Focus "History" } \\
\text { things to history. }\end{array}$ & $\begin{array}{l}\text { Create a coher- } \\
\text { ent narrative } \\
\text { where Leni Rief- } \\
\text { enstahl is viewed } \\
\text { in relation to her } \\
\text { time. }\end{array}$ & $\begin{array}{l}\text { Establish how } \\
\text { different stories } \\
\text { present specific } \\
\text { narratives. }\end{array}$ \\
\hline $\begin{array}{l}\text { 3. Ironic produc- } \\
\text { tion of propa- } \\
\text { ganda for con- } \\
\text { temporary use. }\end{array}$ & $\begin{array}{l}\text { Focus } \\
\text { "Present/Future" } \\
\text { Connecting past } \\
\text { and history to the } \\
\text { present and the fu- } \\
\text { ture. }\end{array}$ & $\begin{array}{l}\text { Establish how } \\
\text { propaganda is } \\
\text { used in the con- } \\
\text { temporary politi- } \\
\text { cal climate. }\end{array}$ & $\begin{array}{l}\text { Analyze what } \\
\text { are the cultural } \\
\text { codes of today } \\
\text { that are used to } \\
\text { influence choic- } \\
\text { es. }\end{array}$ \\
\hline
\end{tabular}

These are specifications of the ways of what Körber calls methodical competence which "spans from the perception of any uncertainty referring to time via the activation of earlier insights, concepts and categories to the start of the methodically controlled process of re- and deconstruction" (Körber in this volume).

With "focus" in the table above, we try to emphasize the specific temporality that the students were supposed to work on. As should be obvious, the past is connected to the future in history (and vice versa) rooted in the present. All three levels involve the full employment of historical learning, but the pupils will have their assignment and consequently their presentation tied to past, history and present/future as analytical categories. There are no differences in value in the sense that one or each of these is more or less difficult than the others, but during the presentations it will be clear whether or not the pupils are aware of using mainly reconstruction or deconstruction.

One small note on why we set some clear limits as to how they could work: It is vital in our understanding of history and in the pedagogical 
ideas underlying the work of historical consciousness that one learns to ask questions based on the historical material that one encounters. This is what is called inquiring competence. Inquiring competence "spans from the perception of any uncertainty referring to time via the activation of earlier insights, concepts and categories to the start of the methodically controlled process of re- and de-construction" (Körber in this volume).

In order to stimulate this competence we asked open-ended questions, asked them to make descriptions, or asked them to produce some material themselves.

\section{Popular culture, values, and propaganda}

When it came to the contents of popular cultural expressions, it was of great importance to show how the cultural stereotypes and hierarchies were represented. Here it was significant to show the transfer from historical examples to contemporary ones. In using the dichotomy between "us" and "the others", we postulated continuity in reading and interpreting history. This is the level of historical consciousness described as traditional by Rüsen: "Traditional orientations present the temporal whole which makes the past significant and relevant to present actuality and its future extension as a continuity of obligatory cultural- and lifepatterns over time." (Rüsen 2004: 71). Here the permanence of history was explored. As explained above we used cartoons, video games and movies/TV-series, in order to stress how aesthetical forms always stand in a relation to the society in which they are created. We presented history as tradition, but in a critical way where the pupils were shown how aesthetic forms and elements formed a link between popular culture and ideology. In order to make this link clear and visible we had to show how the content of one such expression had changed with the ruling ideology. This is then an introduction to what Rüsen calls exemplary historical thought and it "discloses the morality of a value or a value system culturally embodied in social and personal life by proving its generality" (Rüsen 2004: 74).

In general the project "Historical Propaganda and New Popular Cultural Medial Expressions" can be said to operate within the exemplary type of historical consciousness, but within a critical variation as specified above.

Our concept of propaganda needs some explanation. In the debate of how to understand propaganda, our heuristic definition will problematize the focus on the intent of the sender - we will follow the definition 
applied by Gulseth from Jowett and O'Donell to the Rwandan genocide: "Propaganda is a deliberate and systematic attempt to shape perceptions, manipulate cognitions, and direct behavior to achieve a response that furthers the desired intent of the propagandist" (2004: 27). The reason for such a modification is that since our material was made up of popular cultural expressions such as movies, games and comics, we would end up as conspiracy theorists if we tried to frame some sort of intent or premeditation. In our work with the pupils we aimed to explore the cultural codes within contemporary popular cultural expressions and the implicit values. The point was to leave the exploration of possible intention to the pupils (and to be approached in the discussion during presentation). Our goal was to make the pupils aware of how they themselves take contemporary medial expressions for granted by reflecting contemporary expressions in the light of historical expressions.

We aimed at challenging the pupils to try to orientate themselves in history through our introduction on content and form. This orientation would then consist in an uncovering of the interdependence between content and form, which would constitute a very high degree of historical learning and understanding - in the scholarly sense. In relation to propaganda, this would then consist in exploring the historicity (reconstruction) by comparing with other objects in the specific culture to grasp the issues taken for granted in that cultural sphere (deconstruction). Here we operate with a cultural relativist notion of truth. Such a truth notion created difficulties for the pupils when it came to making ethical as well as historical orientations, as I will show later. This understanding of truth is tightly connected to our modified notion of propaganda since the final un-covering of the object will be the equivalent to the annihilation of the object and thereby any question of intent will also evaporate since the intention must be seen to be the constitutive factor of the message that is contained within the expression. ${ }^{5}$

This understanding of truth is akin to what Rüsen is aiming at in the genetic type of historical consciousness where the temporality of past events stops being a threat to us, but becomes a potential for future choices (Rüsen 2004: 78-80). This associative characteristic of a diachronically self-reflectedness has also its counterpart in orientation towards contemporary analysis for future choices, as is elaborated elsewhere by Rüsen:

5 It follows from this that propaganda is then the claim that its authors/producers are "wrenching what is hidden from out of hiddenness", as Heidegger would phrase it (Heidegger 2002: 100). 
"Synchronically identity integrates the different relationships of an individual or collective 'self' to others into a unit in which the self is aware of itself. It 'reflects' (bends back) the relationship to others back to the self thus furnishing an internal unity in the variety of its manifold relations to others. Diachronically this self-reflectedness is related to the change of the self and its relationships to others in the course of time. In this respect identity is a concept of continuity of the sameness of oneself in the changes that every person and group have to undergo in the course of their lives" (Rüsen 2007: 38).

In addition there is the issue of "identity concealment", i.e. that the "propagandists do not want their identity to be known" (Jowett \& O'Donnell 2006: 44), which creates further challenges when it comes to disclosing the intentions of the sender.

The main scope of the project in teaching about propaganda is then to make the pupils aware about how past popular culture reflected and recreated the life conditions of that time and thereby making them able to see how their life conditions here and now are both reflected in and influenced by popular culture and, consequently, their choices and thus the future.

\section{The pupils' presentations}

Here I shall move from the project's general background towards what the pupils themselves did and presented. There are of course different ways of measuring success. And when it comes to exercise no. 3 - producing ironic propaganda - it is not easy for a group of pupils to produce both concepts and results in 90-120 minutes. On the other hand, these are challenges inherent in educating through exhibitions with limited time at our disposal. In addition, we had developed a program for 15-16 years old pupils, but the main age groups present were 13-14 years old.

The first exercise: "Analysis of historical propaganda from the $M y$ thos Leni Riefenstahl and the permanent exhibition" could be solved in many different ways, but the majority of the pupils included Nazi propaganda from the 1935 exhibition "Wunder des Lebens", brutal treatment of Jews and pictures of Adolf Hitler. It was a tendency to look for the strongest and most emotionally charged objects and not so much Nazi propaganda as such. This suggests that the focus "Past" is a difficult one for 14-year olds. Some had a good grasp on the difference between (more or less intended) documentation and propaganda, but the majority analyzed rather the objects in terms of "us" and "the other" than through the intention of the artists of producing propaganda. This insistence on 
using the traditional level of historical consciousness can be seen as a result of our introduction. Instead of looking for the genre of propaganda, they looked for the continuity in exclusion - regardless of form. The pupils had problems in entering into both a reconstructive ("Establish how propaganda was used") and a deconstructive ("Go through the narrative of the exhibitions with the aim to identify propaganda") mode with focus on the past. With reference to Karlsson's contribution in this volume, we could interpret these findings to different uses of history. The pupils got very interested in the distinctions made by propaganda, and thus related to the images in either a moral or an existential manner. The scholarly use of history thus veined into the background.

The second exercise: "The history of Leni Riefenstahl - create one biography where she is good and another where she is evil" begs the question on what is good and what is evil. The following oppositional pairs were the main findings:

- She supported Hitler because she believed in him (good), but lied later about her own involvement (evil).

- She was a Nazi (evil), but a great artist (good).

- She supported Hitler and was a fan of an ideal body (evil), but a good photographer (good).

- Ruthless pursuing her own career (evil), but a good director (good).

- Worked for the Nazis (evil), skilful in marketing herself (good).

- Showed that the Nuba where strong people (good), but helped to stage Hitler's rallies (evil).

These different pairs are to some extent contradictory. Although, in the following dialogue with the pupils we discovered and elaborated on how history can be interpreted in different manners and how, in the case of Leni Riefenstahl, it actually is not easy to pinpoint exactly where her legal and moral responsibility for Nazi atrocities lies. On this basis one could argue that we had some success in working within the deconstructive mode ("Establish how different stories present specific narratives."), but when it came to the work of the pupils within the reconstructive mode ("Create a coherent narrative where Leni Riefenstahl is viewed in relation to her time.") they often created an epithet "Nazi" outside of time and space and with "evil" as the direct extension. There were of course some exceptions to this - "She supported Hitler because she believed in him".

This exercise can be said to constitute an intentional use of history as a source for morality (see Karlsson in this volume for the different uses of history) 
For the third exercise, "Ironic production of propaganda for contemporary use", some groups chose to make films, others posters (drawn or ICT-produced) while a last category made illustrated stories in PowerPoint. Many of the propaganda products centered around the dilemma concerning how cool it is to be a part of the crowd and how being part of a crowd is "un-cool", which is very much a part of youth culture; others on how "un-cool" it is to be stupid and how stupid it is to be cool; others again touched upon commercials and their way of promoting lifestyles. One group worked on sexual preferences. No one made political propaganda, except in a broader sense of commenting upon societal trends that they dislike. Again the deconstructive part ("Analyze what are the cultural codes of today that are used to influence choices.") of the exercise was the one preferred by most groups. Maybe if we had changed our reconstructive understanding of this specific historical orientation to "Establish how propaganda is used in the contemporary cultural climate" we would have been closer to both what the pupils actually produced and what I believe we actually wanted to carry out, which was to make the pupils reflect on what they sense are the codes in popular culture used both in advertizing and propaganda.

Both in exercise 1 and 2 the historicizing around propaganda and Leni Riefenstahl did not fully live up to our attempt to create a space for historical orientation, since most of the solutions to exercise 1 were just pictures of victims or perpetrators from World War II. Combined with the ahistorical uses of the word "Nazi" this suggests that there might be more suitable topics than the Holocaust for opening up for historical experiences: The relation between some words like the Holocaust, Nazism and the phenomena they might be associated with can be understood as moving away from the phenomenal to the noumenal sphere, or universalizing the narratives about the Holocaust (Kverndokk 2007: 254-262). Hereby the specific historical crimes and atrocities are attached to a moral universe expressed in a battle between good and evil, and this battle becomes the focus of attention - instead of the mediums through which these evil persons and institutions conveyed their message and how this message refers to the past. The solution to these dilemmas might be found in distinguishing between different uses of history. Exercises tied to propaganda are related to the ideological use of history while our dichotomy between "us" and "the others" was presented by us as a historical continuity. From the start we put too much emphasis on the structure in the communicative situation and too little on the meaning in the communication - we stressed the structural similarities between Rambo 3 and 24 without being able to go deeper into the genres or investigate the particularities of each phenomenon. Such a linear and 
traditional presentation of history might interfere with the uses of history.

Furthermore it was difficult to see how the pupils approached the past as different from the present in all 3 exercises.

In hindsight I would argue that we should have presented some form of communicative semiotic model resembling Greimas' actantial model where there is focus on sender, message, receiver, but also on the role of helpers and adversaries, in order to open up for further analysis of propaganda. Hereby we could have focused on the axis of transmission where all types of communication consists of three parts (sender, message, and receiver) and on how these should be analyzed separately and in relation to each other. And further, we wanted the pupils to try to orientate themselves after having received a presentation focusing on the content and the form of propaganda.

However, in their deconstructive efforts the pupils demonstrated their capability of relating the content of a narrative to its form, especially when pointing to some of the clear dilemmas in youth culture. This capability is fairly advanced and shows that they have an understanding of society of which they are a part that is nonreductionist. The diachronically self-reflectedness was not used on a meta-reflective level by the majority of the pupils - which in my opinion depends on the material presented to them, still they were fully capable of showing a synchronical self-reflectedness.

\section{References}

Gulseth, Hege Løvdal (2004): The use of propaganda in the Rwandan genocide : a study of Radio-Télévision Libre des Mille Collines (RTLM), MA in Political Science - University of Oslo, http://www.duo.uio.no/publ/statsvitenskap/2004/19095/19095.pdf

Hägelmark, Carolina/Johansson, Anna (2007): Historiemedvetande och folkmord. En enkätundersökning om vilka faktorer som styr historieundervisningen på gymnasiet, Växjö universitet, http://www.divaportal.org/diva/getDocument?urn_nbn_se_vxu_diva -1378-2_fulltext.pdf.

Heidegger, Martin ([1931/32] 1997): Vom Wesen der Wahrheit: zu Platons Höhlengleichnis und Theätet, 2. Auflage, Vittorio Klostermann, Frankfurt am Main.

Heidegger, Martin (2002): The Essence of truth: on Plato's cave allegory and Theaetetus, Continuum, New York. 
Jowett, Garth S. / O’Donnell, Victoria (2006): Propaganda and Persuasion, Sage Publications, Thousand Oaks, London \& New Dehli

Kvendokk, Kyrre (2007): Pilegrim, turist og elev, norske skoleturer til døds- og konsentrasjonsleirer, Linköping Studies in Arts and Science No. 403, Tema Kultur och samhälle, Linköpings Universitet, Institutionen för studier av samhällsutveckling och kultur, Linköping, http://liu.diva-portal.org/smash/get/diva2:16775/FULLTEXT 01.

Körber, Andreas/Schreiber, Waltraud/Schöner, Alexander (eds.) (2007): Kompetenzen historischen Denkens: Ein Strukturmodell als Beitrag zur Kompetenzorientierung in der Geschichtsdidaktik Band 2, ars una, Neuried.

Rüsen, Jörn (2004): Historical Consciousness: Narrative Structure, Moral Function and Ontogenetic Development. In: Peter Seixas (ed.), Theorizing Historical Consciousness, University of Toronto Press, Toronto.

Rüsen, Jörn (2007): "Holocaust Experience and Historical Sense Generation - a German Perspective". In: Fortid 2-2007, 37-47, http://www.fortid.no/fortid_web/fort0207.pdf.

Schreiber, W. and S. Mebus (eds.) (2006): Durchblicken - Dekonstruktion von Schulbüchern, 2. Auflage, ars una Verlagsgesellschaft $\mathrm{mbH}$, http://www1.ku-eichstaett.de/GGF/Didaktik/Projekt/Bosch_ Projekt/Basisbeitrag_2Auflage.pdf. 



\section{The Culture of Memory in the “Grandchildren Generation" in Denmark}

HELLE BJERG

The purpose of this article is to present an empirical study of the culture of memory of World War II and the German occupation of Denmark within the "grandchildren generation" in Denmark. This generation's culture of memory presents both continuities reaching back to the national master narrative established in the immediate postwar years, and recent developments allowing new perspectives and narratives to come into view, without totally wiping out older ones. In the following, I shall characterize the culture of memory of the third generation using examples from one individual interview and one group interview with members of this generation in pointing to the characteristics of internationalization, victimization, universalization and identification. Finally I will outline some didactical possibilities and challenges posed by the uses of history of WWII presented within this generation's culture of memory.

The findings to be presented in this article stems from the Danish part of the European research project "Traditions of Historical Consciousness" (Welzer 2007). The project was a follow-up on a German study on the transition of memory of the Third Reich within German families in three generations (Welzer et al. 2002). Within the same framework, the European project offered a comparative perspective on the traditions of historical consciousness within the Netherlands, Norway, Denmark, Serbia, Croatia and Switzerland (Welzer et al. 2007). From 2002 to 2005, 20 Danish families in three generations were interviewed on the transition of memories of the German Occupation and WWII within these families. Furthermore, a series of focus group interviews with members from the same generation were conducted to follow 
the exchanges on WWII amongst representatives from the same generations. In this article I shall be presenting empirical examples from an individual as well as a focus group interview in order to exemplify some of the findings, which were developed on the basis of the Danish material as well as comparisons within the overall project.

The analytical concepts of "the culture of memory" and "uses of the past" to be used throughout the article are to a certain extent chosen in line with the argumentation put forward by Karlsson in his discussion on the concept of historical consciousness and the analytical operationalization into "historical culture" and "uses of history" (See the contribution by Karlsson). Still, within this specific context I find "culture of memory" more appropriate, as the concept of memory alludes more to the private, un-official ways of using and presenting the past than does the concept of the culture of history. Moreover, memories as well as historical consciousness were the concepts used within the research project as a whole.

\section{World War II - An image of significance}

As an introduction to the subject matter I will present an extract from a focus group interview conducted with young people born after 1975 . Whereas the individual interviews conducted in the study took a national starting point, the focus group interviews were prompted by five photographs mainly depicting scenes to be interpreted as relating to WWII and, to a lesser extent, to the occupation of Denmark. ${ }^{1}$ In the interview, the participants were asked to relate to the photographs, an opening which raised a discussion amongst them on which pictures they found most significant in relation to their historical consciousness of WWII:

Karina: THAT picture, number three. That's really the sort of picture where you think of World War II, of a concentration camp. [...] At least that's what I

1 The five photographs depicted "familiar" scenes from WWII, but were not known icons. As such, the photographs had a certain vagueness allowing for the associations of the interviewees to place the pictures into the historical context. The pictures were: 1: Inhabitants fleeing during the last days of fighting in Berlin, 1945. 2. Stukas taking off from an airstrip in the Soviet Union 1941. 3: A starved Soviet prisoner of war in the camp Stalag 326 1941/42. 4. A pile of corpses in a barren landscape showing "The church yard" of the satellite camp Adabasch, 1941. 5. A Danish Woman who had tried to use a German uniform as disguise, but was discovered and dragged through the crowds in the streets by two armed resistance fighters with armbands. 
think of, when I think of World War II, then I think of the terrible things that happened, of the concentration camps. And that is such a [...] [apologizing giggle] typical picture showing such a starved man. [...]

Mikkel: I do not think of it in quite the same way. [...] It's not like, when I say World War II, that's not what I think of first. [...] Then I'm more into war/ Louise: Like picture number two.

Mikkel: Yeah, pictures with war [scenes] and so on.

Karina: Airplanes.

Louise: I think number two is a bit 'Pearl Harbor-like' [the movie].

Mikkel: Actually, I don't think about it [the Holocaust]/ I mean, I know it's there, when I think about it for longer, but when I think of World War II it's war and airplanes.

This brief discussion addresses three features characterizing the culture of memory which will be dealt with in this article. Firstly, it shows the workings of the iconography of the culture of memory where different icons link up to different narratives of WWII.

The narratives may be related in some ways, but to a certain extent they also lead separate lives within the culture of memory. Significant icons are images of the Holocaust, of battlefield scenes, of Hitler and National Socialism, but also icons relating to the national narrative of the German occupation in Denmark like rationing cards, curfews, resistance. Secondly, I shall later be making a point concerning Karina's pause and apologizing giggle when referring to the picture of the starved man as "typical". It is my assertion that this giggle is a gateway to the emotional landscape, which this generation moves into when touching upon the memory of the Holocaust. In that sense, the Holocaust takes up a specific and significant place within the culture of memory still it also exposes some more general features related to the quest for identification, but also the tendency of universalization in the use of history. Finally, we see how Louise refers to the movie "Pearl Harbour" in her attempt to interpret the significance and meaning of the historical material on the table. This points to the ways in which this generation draws on very different sources and references when dealing with the past, and more-over how they use the past in different ways and for different ends.

\section{A long-lived master narrative of the Occupation}

Below I have chosen to let 19-year-old Amalie speak on behalf of her generation, as I intend to use the individual interview with her as an example of how the culture of memory can be said to work within the third generation. In the interview quoted above, the imaginary prompted by 
the photos was mainly focusing on WWII and the Holocaust in an international perspective, whereas the individual interviews were designed to take the national context of the war as their starting point by asking what the grandparents had told about the occupation of Denmark:

Amalie: He (Her grandfather. HB) did tell about the air raid shelters and that you sometimes could hear planes roaring in the sky and things like that. And something about the girls who slept with the soldiers, some Danish girls who had relations with the soldiers and had their hair cut off. It has probably always been those kinds of things that have interested me [...]. And people who said they were on the Danish side, but who were actually on the side of the Germans. Traitors, they were called.

Helle: What do you think about how it was for people, if you should put it in you own words?

Amalie: Then I think that the solidarity was probably strong in some ways. So even though it was negative, it probably also brought people closer together. And, well, one lived in insecurity, and that must have been really awful, but in another way it has/ I see people as very close. That people were brought together. That is how it is with hard times and times of distress.

Amalie gives a very condensed and conventional version of what Bryld and Warring frame as the master narrative of the Danish occupation (Bryld/Warring 1998: 55 pp.). This narrative puts forward an exclusively national perspective and offers a mythically charged image of a small nation, occupied by a greater enemy, but at the same time united in either open, military resistance or quiet support by the whole population. Within this narrative, the policy of collaboration is regarded as a prerequisite for protecting the people while at the same time opening up other ways in which resistance could be expressed. Furthermore, a very clear line is drawn between the united Danish people on "the right side" and groups on "the wrong side" such as Danish members of the National Socialist Party, volunteers on the Eastern Front, collaborators, girls with romantic relationships with German soldiers and their children. These individuals or groups are excluded from the national community of resistance, and as such did not only experience different forms and degrees of social stigmatization and exclusion in the aftermath of the war, but are also excluded from the national master narrative. In a comparative perspective it is interesting and relevant to point to the resemblance between the Danish and the Norwegian master narrative (Eriksen 1995) as well as the way it functions within the third generation's culture of memory (Lenz 2007).

The national master narrative functions as a main interpretative framework within the third generation, not least in understanding and 
narrativizing the memories of the grandparents. This can be seen in the quote where Amalie refers to how the memories of grandfather "fit" the overall national narrative. In this way the national and the "local" memories of the family are closely woven together, as the master narrative exerts a homogenizing effect on the culture of memory in the sense that stories or memories differing from this narrative are either not told or overheard because they do not fit this interpretative framework. Moreover, this quote points to a pattern of relating to the Occupation as a time of hardship, but also of solidarity and a sense of community, which is seen as the opposite to the stressful and individualistic conditions of today. The Occupation is a period when the choices to be made where few and simple - and where people stood together: "Sometimes I long for that time even if I never lived it myself", as a young woman says. Even when the grandchildren take an ironic stance towards their romanticizing view on the Occupation, they still draw on the mythical interpretation of the master narrative, where the Occupation both becomes a signifier for a battle between "good and evil" and simultaneously "the good old days".

\section{New narratives - new perspectives}

In the Danish culture of memory the national master narrative has existed alongside, but often not related to the international history of WWII or, as pointed out by Karlsson, the international events is seen from a national perspective. This pattern can still be found within the younger generation, but is also slightly in the process of reconfiguration: Firstly, the exclusively national perspective is often related to or compared with the international context of WWII, and secondly, WWII and especially the Holocaust is gaining influence as a point of reference. This tendency shows itself in the individual interviews prompted by a national context, as these interviews very often include comparisons as "it was much worse elsewhere" and that the Norwegians or the German people suffered much more. In the case of Amalie, the international perspective emerges in the shape of narratives of the Third Reich, the Holocaust and the role of the German people. Amalie expresses the necessity of preserving the material remnants of the concentration camps in order to be able to confront people claiming that the Holocaust never happened. Furthermore, she very explicitly reflects on how her understanding of the situation of the German people was reconfigured when reading the novel "Lunch with Mussolini". She stresses how reading this novel gave her a new perspective on the living conditions of a German family dur- 
ing the Third Reich, leading her to a new understanding of how the Third Reich could come about. Amalie highlights the importance of seeing history "from both sides" as opposed to her experience of history teaching in school where the history was only seen from "the perspective of the Jews": Which is fair enough, but a lot of the other stuff is lacking, I think. It's only now after reading this book that I've [...] You always knew that they didn't have freedom of expression, that they were deceived. But now I have had it put into words how it was. I hadn't read about it before, I hadn't been able to feel it myself. And that's what you can do, when you read fiction or see a movie. Applying the terminology on reflective historical thinking presented by Andreas Körber in this volume, one might say that Amalie reconstructs the narrative of the Third Reich and the Holocaust when she appropriates this new perspective into her understanding. At the same time she starts asking more $d e$ constructive questions when she reflects on how the history of WWII and the Holocaust has previously been presented to her. In the reorientation of her historical consciousness on the Third Reich, the case of Amalie exemplifies yet another two features of the memory culture of her generation. Firstly, she draws a moral or at least political connection between the past and the present by using the history of the Third Reich to point to the importance of a democratic government allowing free speech and discussion, seeing the lack of free speech as one of the preconditions for the Third Reich (See Karlsson's article in this volume for elaborations on this "politico-pedagogical" use of history).

Secondly, this reorientation leads her to positioning the German people as victims - not only perpetrators - of the war. With this move, Amalie points towards a very significant feature in the memory culture of the third generation. Here it seems that inclusion into a history of WWII relates strongly to being assigned a role as a victim. In a way this victimization means that an individual or a group can be freed from guilt and become legitimate subjects of history, but at the same time they become objects of history as their role as active agents is transformed into rather passive victims (See Ahonen in this volume for a discussion of victimization within the culture memory). Within the interview material as a whole, this change of position and/or the process of being rewritten into history, is to some extent shared by the German people; the girls who had romantic and sexual relationships with German soldiers, Danish volunteers on the eastern front, as well as the German soldiers constituting the occupying power in Denmark ${ }^{2}$.

2 This tendency may partly be due to the fact that since the mid 1990s new historical research has been conducted on the history of some of these 
Relating the case of Amalie to the general description of the culture of memory of her generation, I would say that her case shows the significance and perseverance of the national master narrative in structuring what seems relevant in history and what meaning to gather from this period. Still, she also represents the tendency of developing a more international perspective, but first and foremost she exemplifies the strength of the configuration of the victim as an important signifying figure within the memory culture of the younger generations.

\section{The emotional imperative of the Holocaust}

Moving beyond the national context, the Holocaust holds a strong position in the memory culture of the younger generation. And compared to the former generations - the grandparents' and parents' generation - it seems that the Holocaust is gaining influence and seems to be more present within the memory culture of the third generation. There is no doubt that for the younger generation the Holocaust represents the strongest lesson to be learned from the WW II. Whereas "Never another April ninth", referring to the starting date of the German occupation in Denmark, was the motto of the national master narrative and in that sense of the generation of the grandparents, "Never another Holocaust" could be said to be the motto of the younger generation.

A certain explanatory framework is applied in order to explain "how it could happen" when referring to the Holocaust. In the case of Amalie, as well as in many other interviews, the explanations point to Hitler his demagogical capabilities, his reconstruction of Germany in a time of worldwide economical crisis, but also the fear and lack of alternatives of the Germans involved in the genocide. And again we see how the openness of the third generation towards integrating perspectives previously excluded from the public memory culture, takes the form of victimization.

Furthermore, there is also a strong tendency to use WWII and the Holocaust as steppingstones for referring to present wars (at the time of the interviews the wars in Afghanistan and Iraq were the most acute) and recent atrocities and genocides. When connections are made between the historical events of WWII and the Holocaust and present conflicts, it is mainly not in the form of specific historical or factual comparison or analysis. In that sense WWII and the Holocaust are not treated as specif-

groups within Denmark. Se Bundgaard et al. 1998; Lylloff 1999; Warring 1994. 
ic events within specific historical developments, but rather as icons or symbols of war and evil as such:

Dorthe: [...] That picture [number three], it also resembles that famous picture from Yugoslavia.

Michael: Yes.

Peter: It does, actually.

Interviewer: I hadn't thought about that, actually.

Jens: That's just 'history repeating itself'.

Dorthe \& Anders: Oh yes!

As was the case with the nostalgic tone in the use of the Danish occupation, the past is dealt with in an a-historical way, where the Holocaust is treated as a universal example of the theme of evil and inhumanity replayed and repeated. In the quote above this occurs in the form of an iconographic resemblance, also exemplifying how memory is collectively shared and constructed (Welzer et al. 2002). Within the reference to these icons of memory, while not actually unfolding the specificities or the meaning attached to them, it seems that there is a common ground of understanding, which I have elsewhere described as a shared "encyclopedia of public memory" (Bjerregaard/Bjerg/Lenz 2006).

Furthermore, the Holocaust does not only act as a moral imperative, but also as what I have chosen to call an emotional imperative. Let us look again at Karina's apologizing giggle referred to in the beginning. I suggest that by interrupting herself when referring to the picture as "typical", Karina reflects an unease which is sensitive to the question of whether or not it is appropriate to deal with the Holocaust as any other historical event and in that sense treating human suffering as "representative" or "typical".

Later in the same interview the participants discuss their difficulties in relating to the Holocaust:

Louise: But then again, just imagine if it were you. If you try to put yourself in the shoes of those people [...] really, really try to relate to how it would be if somebody just decided 'Your race is not good enough, because you are 1.70 or something' $[\ldots]$

Karina: I just think, the first time I visited a concentration camp/ I think, I've tried it three times/ Then I was completely/ I mean, I felt sick/ And you were shown where they were gassed and you walked around in there/ And I just thought it was SO disgusting and I felt like crying and was beside myself, but already the second time, a year and a half later, when I also went on a trip where you went by a concentration camp/ Of course it was still TOTALLY 
disgusting, but still/ Then I also thought my own reaction was disgusting, that you already/ I still thought it was really awful, but that I/

Louise: You took it a bit easier/Lighter?

Karina: Yeah, a bit lighter than the first time. [...]

Jesper: It's terrible, but I think it's hard to imagine it for yourself/ I must admit that I didn't feel sick/ It's terrible and disgusting, of course, that it could happen, but [...] I don't know why it doesn't affect me so much, but [...] I can easily see that it's terrible, also what you're saying, that it's been seen so many times, that you've heard the story again and again and seen so much on film, that you're kind of fed up with it.

What is discussed here is how to approach the Holocaust - or rather what it does to you when you approach the Holocaust. Following this discussion it seems that there is an imperative to feel both a certain horror and disgust when confronted with the issue, and a capability to identify with "how it felt" to be in the position of the victim. ${ }^{3}$

This "emotional imperative" carries with it didactical possibilities as well as challenges. On the one hand it supports the position of the Holocaust within the culture of memory as an event still regarded as highly relevant to relate to, learn about and learn from. On the other hand it may also put forward a way of dealing with the Holocaust where feeling the appropriate and the strongest emotions becomes the measure of "getting it right". In that sense the emotions set the standard for the scale on which the approach to the Holocaust is measured and evaluated, in the sense that "if you don't feel - you fail". Again there seem to be common traits in the memory culture within Denmark and Norway. As an example, crying seems to be obligatory after the emotional detour into the past in the "White Buses to Auschwitz"-trips attended by app. 10.000 young Norwegians every year (Kverndokk 2007). Going back to Karina's apologetic giggle and her reflection on her three visits to concentration camps, I think her giggling can be interpreted as a kind of apology for her approach to the picture of the unique suffering of this one individual, who is at the same time a representative of so many other individuals that the suffering becomes immense. By referring to this picture as "typical" it seems that she offends the suffering which should not be typified or analyzed, but left untouched and respected - or sacred, one might say. The following discussion also shows the risk of banalization (Eschebach 2005) in the form of a wearing-out of the emotional appeal of the remnants, the pictures, the stories of the Holocaust; You get "fed up" or "It's not shocking any longer". Another element in banalization

3 In the overall project a very similar discussion can be found in focus group interview with Dutch youngsters (Jensen/Moller 2007: 236 pp.) 
points to the moral function of the Holocaust where it is lifted out of the historical context and is taken, on account of its immensity and incomprehensibility, to represent pure evil. The use here is related to emptying the past of any specific historical content and using it as a reference for the necessity of respecting human rights and preventing human atrocities.

The didactical challenges to be singled out here is pointing to the need of balancing the immediate emotional appeal and identification within the confrontation with the Holocaust, with the competence of reconstruction and understanding of the historical specificities leading to the occurrences within the emblematic issue of the Holocaust. This may again form the basis for an analysis of what the many complex "lessons to be learned" are, rather than extracting only one single essential message.

\section{Using media - using the past}

The final question to be addressed is how this culture of memory gets established or, more specifically, what sources the young generation draw on in constructing their relationship to WWII and the Holocaust.

Firstly, this generation's culture of memory clearly shows that the sources for developing historical consciousness are definitely not made up of formal history education alone. Media such as film and television are very much drawn upon as sources of knowledge, interest and identification, but also the narratives of their grandparents are identified as important. Still, the national master narrative of the Occupation forms an interpretative framework for what counts as relevant within the culture of memory.

When Louise remarks "It's a bit Pearl Harbor-like", she flashes a significant feature of this generation. Very often fiction - first of all movies but also novels - is used as a reference for "how it was" or for what kind of stories have made an impression. The standard reference in a Danish context is the television series "Matador" dealing with the period before and during the war in a small Danish provincial town. The series was shown on Danish television several times during the last decades, making the narrative and iconography a common reference point for all three generations,also references to movies occur very often in the third generation interviews. In the group interview quoted above there are media references like "Pearl Harbor", "Schindler's List", "Das Boot", the television series "Band of Brothers", the Anne Frank diary. In addition, especially the boys seem to be consumers of documentaries (on 
Discovery). The media referred to also point to the way WWII and the Holocaust is "used" today. Here there is definitely an element of entertainment in the way the media products are consumed, but at the same time the media also create a basis for identification, for opening up to new narratives and perspectives, for gaining knowledge and for further questioning. The significance of movies for the culture of memory may fortify the tendency of a morally oriented use of the past as movies nearly always feature one or two main actors or stars. These are depicted as real persons having to make tough moral choices. This, of course, strengthens the image of WWII as a moral war where the choices of the few determined the fate of the many. Furthermore, the family tales also have this structure, where moral high ground is claimed - even when resistance was only lived out passively.

To sum up, the interviews show a wide range of ways of using history. Moreover, as far as their use of different types of media is concerned, such as fictional movies, documentaries, and computer games the younger generation can be said to use the history of WWII for entertainment and "infotainment". Another - and very different - usage is their way of integrating the past into moral considerations of right and wrong, the kind of usage termed "politico-pedagogical" by Karlsson in this volume. Within this usage, the Occupation or WWII is related to issues such as human rights or war, but very often the connection is made in ways that lift the historical incidents out of the historical context, dehistoricizing and universalizing them in the process. The national narrative is also used in a nostalgic form as a frame of projection for a bygone time "when life was simple and there was still such a thing as solidarity". In this usage, the past turns into a mythical landscape that is very much in contrast to the complexity and confusion of today. Still, there are also tendencies of a highly reflective way of dealing with the past related to the way in which new perspectives are challenging the national master narrative. Here, some of the informants do not use the past for moral judgment, but rather as a source of moral reflection on the dilemmas of the people then and of themselves now, dilemmas without any clear answers.

The varied uses of different media as sources not only for gaining knowledge, but also for generating interest, excitement and identification concerning WWII and the Holocaust, pose fruitful challenges for history teaching aiming at the development of reflective historical thinking through the development of competencies. It invites history teaching of any kind to work both with and against different types of representations of WWII and the Holocaust, in the sense that it needs to enable pupils/students/visitors to use the principles of reconstruction and decon- 
struction (See Körber and Lenz for theoretical and empirical elaborations of these principles) as well as concepts for assessing and discussing the quality and reliability or rather plausibility of the media products consumed. In the interviews conducted in this study, movies or books are very often used in arguments for a certain position or fact in relation to the history of WWII without any kind of reflection on the reliability of the source or of the specificities connected to the kind of narrative presented by one form of media or the other.

\section{Conclusion}

The specific study of the memory culture of the third generation in Denmark does not only reflect specific Danish or generational features. In relation to the findings of the overall project of "Transitions of Historical Consciousness", the characteristics of the memory culture put forward here also reflect broader tendencies, both in a generational and an international perspective (Jensen/Moller 2007; Welzer et al. 2007). To sum up, the memory culture of the third generation can be said to oscillate different "layers" of memory culture: The national master narrative of the Danish Occupation provides an encyclopedia of icons of memory and an exclusive narrative of the Danish people united in solidarity and resistance against both the outer enemy and the different groups of "traitors". This narrative carries a clear moral lesson of resistance and solidarity to be learned. Still, this narrative is also subject to a certain degree of questioning and reflection as the perspectives of hitherto excluded groups and themes are brought to the fore and are being incorporated into the culture of memory. This process is what Jensen and Moller have coined the "de-heroicized" version of the national past, which seems to exist alongside the narrative of "being on the right side" within the third generation (Jensen/Moller 2007: 255). Moreover, the new tendencies within the culture of memory seem to be trans-generational, but perhaps somewhat more distinct within the third generation. These tendencies take the form of: internationalization, not least in the way the Holocaust moves even further into focus; victimization, where new groups, narratives and perspectives are included, but mainly by passing as victims; universalization in the sense that the events of the war and the Holocaust are lifted out of the historical context and related to general moral issues such as human rights, (evils of) war, genocide - as "the lesson to be learned". Finally, members of the third generation show a widespread tendency to relate to the past by seeking identification and stressing the importance of being able to project oneself into history by feeling the 
horror, the disgust, and the anxiety. The last feature seems not least to be facilitated by the types and the ways in which different forms of media are used in relating to WWII. In that sense the immensity of the historical events still reaches out - it shocks, touches and offends - or at least they are approached as something that should. It only leaves us with the didactical challenge of what to do when affect is not enough.

As such, the didactical challenges and potentials of this development within memory culture are like two sides of a coin: The way in which the events of the Occupation, WWII and the Holocaust still bear the sign of both relevance and interest or excitement for the third generation paves the way for an engagement in and with this period of history. Simultaneously, it represents a danger in diffusing two features of history: On one side the mere fact of specific events in the past. On the other side hand history as the fact of existing in time, which is related to the process of sense making in time. This is what Karlsson in his contribution describes as a delicate balance between the genetic and the genealogical perspectives of history. Moreover, it points to the question, also raised by Karlsson, on whether there is such a thing as an abuse of history. In a didactical perspective one might say that the challenge is to assure and facilitate both processes of identification, not least with shared human themes of, for instance, suffering or agency and choice, but also de-identification and analysis of historical specificities. A reflection of this double-sided challenge could be a history teaching which welcomes the varied forms of media drawn upon by the youngsters as well as the varied usages of history related to this period on the one hand, and on the other hand confronting this with the development of the competences of both reconstruction and deconstruction and for assessing and discussing reliability and validity. This would require the application of both conventional concepts of history as a scholarly discipline and the development of competencies for distinguishing between different types of narratives and media (See the contributions by Körber and Lenz respectively for a theoretical and empirical elaboration on this thinking). If history education about WWII, the Holocaust and related themes only "go with the flow" of identification and universalization, the potential reflection and knowledge based analysis of historical specificities and not least its complexities may be lost. On the other hand the aim must be to fertilize the sense of relevance and relatedness to the past which these themes seem to offer in ways that also leave space for the development of personally relevant meaning-making processes. 


\section{References}

Bjerregaard, Karen Steller/Bjerg, Helle/Lenz, Claudia (2006): "Die Bedeutung der Kategorie Geschlecht bei der Weitergabe von Besatzungserinnerungen in Dänemark und Norwegen”. In: Historische Mitteilungen der Ranke-Gesellschaft, Bd 19 2006, pp.45-66

Bryld, Claus/Warring Anette (1998): Besættelsestiden som kollektiv erindring. Historie- og traditionsforvaltning af krig og besættelse 1945-1997. Roskilde: Roskilde Universitetsforlag

Bundgaard, Claus/Poulsen, Niels Bo/Scharff Smith, Peter (1998): Under hagekors og Dannebrog - danskere i Waffen SS, Aschehoug, København

Eriksen, Anne (1995): Det var noe annet under krigen. 2. verdenskrig i norsk kollektiv tradisjon, Pax, Oslo.

Eschebach, Insa (2005): Öffentliches Gedenken. Deutsche Erinnerungskulturen seit der Weimarer Republik, Campus Verlag, Frankfurt am Main.

Jensen, Olaf/Moller, Sabine (2007): "Streifzüge durch ein europäisches Generationengedächtnis. Gruppendiskussionen zum Thema Zweiter Weltkrieg im interkulturellen und intergenerationelle Vergleich”. In: Harald Welzer (ed.), Der Krieg der Erinnerung. Holocaust, Kollaboration und Widerstand im europäischen Gedächtnis, S. Fischer, Frankfurt am Main, pp. 229-260.

Jensen, Olaf (2004): Geschichte machen. Strukturmerkmale des intergenerationellen Sprechens über die NS-Vergangenheit in deutschen Familien, edition diskord, Tübingen.

Kverndokk, Kyrre (2007): Pilegrim, turist og elev. Norske skoleturer til døds- og konsentrationsleier, Linköpings Studies in Arts and Science, Linköping.

Kverndokk, Kyrre (2009): "Negotiating Holocaust memory in Schooltrip reports". In: Anne Eriksen/Jon Vidar Sigurdsson (eds), Negotiating Pasts in the Nordic Countries. Interdiciplinary studies in History and Memory, Nordic Academic Press, Lund, pp. 263-288.

Lenz, Claudia (2007): "Vom Widerstand zum Weltfrieden. Der Wandel nationaler und familiärer Konsenserzählungen über die Besatzungszeit in Norwegen". In: Harald Welzer (ed.), Krieg der Erinnerung. Krieg der Erinnerungen. Holocaust, Kollaboration und Widerstand im europäischen Gedächtnis, S. Fischer, Frankfurt am Main, pp. 4176.

Lylloff, Kirsten (1999): “Kan lægeløftet gradbøjes?: Dødsfald blandt og lægehjælp til de tyske flytninge i Danmark". In: Historisk tidsskrift, København, Bd. 99, h.1 (1999), pp. 33-6.8 
Welzer, Harald (ed.) (2007): Der Krieg der Erinnerung. Holocaust, Kollaboration und Widerstand im europäischen Gedächtnis, Fischer, Frankfurt/M.

Welzer, Harald/Moller, Sabine/Tschuggnall, Karoline (2002): Opa war kein Nazi: Nationalsozialismus und Holocaust im Familiengedächtnis, Unter Mitarb. von Olaf Jensen, M: Fischer, Frankfurt. 



\section{Strengthening Narrative Competence by Diversification of $(\mathrm{Hi})$ stories}

\section{Claudia LenZ}

In this article I will present a teaching tool aiming at the improvement of narrative competence in the context of historical learning - and more specific: historical learning in museums or at memorial sites. The concept is based on the technique of re- and deconstruction of historical narratives at museums and/or memorials. The example presented here is taken from a teacher training seminar entitled "One past - many narratives", attended by teachers from different parts of Norway. But as will be argued, the tool has the potential to strengthen intercultural sensibility, also in "multi-cultural classrooms" and international teaching settings. The reasons for this potential are partly linked to the changes which memory cultures connected to World War II have undergone in all European countries in recent years. While in the first decades after 1945 memory cultures were dominated by national interpretations (Flacke 2004), the decades after 1968 brought a shift towards selfcritical and more cosmopolite and universal interpretations. This has been reinforced by the special dynamic of international Holocaust commemoration (Levy/Sznaider 2005). (See the contribution by StokholmBanke in this volume.) Today, both the national and the cosmopolitan interpretative framework inform individual and collective/group specific interpretations and uses of the past, alongside with other narratives, originating in stories being told in families or narratives related to local identities (see the contribution of Bjerg in this volume).

The teaching concept presented here aims to foster the learner's competence to relate in a reflected and critical way to representations of 
the past as they are displayed in historical museums. The concept is linked to the following aspects of historical competence:

- The ability to identify and reconstruct musealized historical narratives.

- The ability to re-arrange and re-contextualize these representations of the past for the production of personal, diverging and even multilayered narratives.

In order to contextualize this empirical example, I will first present some basic features of Norwegian history culture and its underlying narrative and subsequently discuss some theoretical assumptions pertaining to the didactical concept.

\section{Sub-layers in the dominant Norwegian narrative}

The Norwegian memory culture requires a brief introduction since the empirical data originate from the Norwegian context.

The dominant narrative about the time of the German occupation of Norway emerged quickly after 1945. It was structured by a dualistic pattern of "German occupiers" versus "a nation in resistance" on the one hand, and "patriots" versus "collaborators"/"traitors" on the other. This interpretative pattern informed historical research, public memory culture and history teaching for decades. Within this framework, by far the most interest was directed towards the resistance movement on the one hand and the general population's rejection against attempts to Nazify Norwegian society, the so called "Holdningskampen" (the fight to "keep" the country, in a symbolic sense) on the other. It is evident that this interpretative framework gave the majority of the population the possibility to identify with the position of good Norwegians/patriots (Eriksen 1995). The flip site of the coin, though, was the social stigmatization of those branded as traitors - party members of the Norwegian collaborationist party "Nasjonal Samling", SS-volunteers and women, who had sexual and/or love relationships with German soldiers. The consequences of this stigmatization were also "inherited" by the children of those who ended up on "the wrong side". Therefore, to this very day, the memories of the time of the German occupation, have remained an emotionally charged topic in many Norwegian families (Lenz 2007, 2008). The Norwegian Resistance Museum, created in the early 1970s by resistance veterans, can be regarded as a materialization of what could be called a "national master narrative" - a version of history becoming so dominant as to regulate every kind of interpretation of this 
specific period. Moreover, power relations in a contemporary society are shaped by the positions that this narrative ascribes to individuals and groups.

From the beginning of the 1970s onwards, a whole range of aspects of war history came into the focus of both professional historians and the broader public interest, notably the collaboration, the treatment of Norwegian women having love relationships with German soldiers before and after 1945 and the fate of the children born out of these relationships. The persecution of the Norwegian Jews, leading to the murder of more than 700 of them, became a topic of public memory culture and memory politics as late as in the mid-1990s. Whereas the investigation of the history of the political collaborators was for the most part fueled by the interest of a young generation of historians in the 1970s (who did not belong to the "resistance veterans" as most of the leading war historians after $1945 \mathrm{did}$ ), the attention for the other two subjects did not spring from professional historians' work but was generated by the activities of groups and organizations from civil society and, in the case of the Holocaust, from abroad. The most striking examples of this development within Norwegian memory culture is the growing awareness of the fate of the children born out of relationships between Norwegian women and German soldiers during the war. Many of these "war children" (in Norwegian, they were called "Tyskerbarn"/ Germans' children) had been stigmatized after the war. They and their mothers were branded as mentally retarded and there were even official political deliberations of how to get rid of them. In the 1980s, an organization of these "war children" was founded, claiming official acknowledgement for their sufferings after 1945 and even suing the state for financial compensation. The developments leading up to the compensation lawsuit and the lawsuit itself received broad media attention, and eventually even a research project was launched, investigating the postwar life conditions of these children (Ericsson/Simonsen 2005). One can say that this complex process of public lobbyism, media attention and historical research has left a deep change in public attitudes - as well as private narratives related to these phenomena (Lenz/Moller 2006; Lenz/Welzer 2007).

The way by which the history of the persecution of the Norwegian Jews became integrated in history writing and public history culture was quite a different one. Here, the interest and awareness for the subject had been increasing in limited artistic and intellectual circles since the early 1990s. But the breakthrough in the public at large was achieved due to the work of an official commission, established in 1996 and reporting in 1997, which investigated the reparations the surviving Norwegian Jews had been awarded after having been dispossessed by the Nazi regime in 
1942. This commission's findings led to both historical research and public awareness for this part of occupation history, which had been a blind spot until then (Maerz 2007).

An investigation into the historical consciousness about the time of the German occupation cannot rely exclusively on public history culture (with historical research being a part of it). People's knowledge, their perception of representations of reality and their interpretations relating to the wartime period are informed by many different sources: family narratives and stories told in the personal sphere, school lessons, media representations (TV, cinema, literature etc.) as well as local and national memory culture (monuments, commemoration days, ceremonies etc.).

The didactical tool to be presented here takes its starting-point in the idea that the historical consciousness of most Western Europeans belonging to the postwar generation is organized by different layers of cultural influences and narrative patterns (See also the contribution by Bjerg). This means that the narratives and interpretations related to this aspect of history are adaptable to different, even contradictory "uses of the past" and can embrace different interpretative options. In order to create the competence of being able to relate actively to the different narratives and interpretations existing in the public (and the private) realm(s), both within history teaching and in a wider sense, it is decisive that all processes of historical learning focus on "critical judgment" with regard to historical narratives.

\section{Theoretical assumptions}

Some of the basic assumptions shaping the concept of using museum exhibitions in order to develop the narrative aspects of historical competence have been extensively presented in the articles of Körber and Karlsson in this volume. Notably, the concepts of "(self-)reflective historical consciousness" and "uses of the past" materialized in historical culture have been elaborated there. I will build on these theoretical premises, focusing on the relevance of narrativity for any construction of "meaning" related to timeliness and, resulting from this, the notion of "narrative competence".

Taking the concept of historical consciousness into consideration when designing tools for historical learning first of all means starting from the idea of "being in time" as an existential feature. This includes the understanding that subjects cannot build any relation to reality nor can they gain agency without the mental operations linking past, present and future together. Without references to experienced or represented 
past and without the mechanisms of selecting and organizing information derived from the past, the flood of impressions constituting every moment of present reality cannot be organized into a meaningful whole. Without references to the past, reality would literally "make no sense". Though the patterns of selection and interpretation derived from past experiences are constantly re-organized within social and cultural frameworks, they represent the basis of subjectivity and agency - which means: the ability to act based on intentions and prospects for the future.

Still, this existential dimension of our relation to the past as subjects and social beings, and hereby the absolute dependence on the relation to the past when it comes to the question of identity (who we are and how we became what we are), cannot change the fact that relating to the past is only possible in indirect ways, via representations. To be existentially related to something absent means being dependent on symbolic reconstructions and communicative practices "verifying" the notions of the past. This creates a tension, which is often solved by cultural techniques of "ensuring" one's own history. The idea of (self-)reflective historical consciousness - as it is also presented in Körber's contribution in this volume and as it informs the teaching approach presented here - is therefore not only linked to the idea of cognitive or intellectual skills. It also refers to the capacity of coexisting with diverse cultures and taking actively part in democratic, pluralist societies.

What is the focus of an approach in which historical learning is based on (self-)reflective historical consciousness and how does narrativity come into play? As indicated in the contribution by Karlsson in this volume, the mental operations of "processing time" are linked to the experience of recognizing oneself and others in the dynamic of past, present and future. We are able to imagine elderly people as the youngsters they once were and the hopes (future prospects) they once had, as well as we are able to imagine small kids being adults in the future remembering us as good or less good parents. This means, we constantly relate to stories placing subjects and their actions in time. And the present needs for orientation, as well as the future prospects, influence the way the past is constructed. In order to do so, several interrelated mental operations are processed:

- identifying and selecting "meaningful events" in the past;

- compounding events within coherent narrative patterns (the formation of "history");

- relating the past to present and future in meaningful ways.

Narrative psychology (Straub 2005) suggests that the individual's capacity to cope with reality is based on these narrative operations; patterns of orientation are gained from selected and "useful" former experiences - 
which might be one's own experiences or cultural representations of other people's experiences.

The capacity to organize reality in this selective and structuring way serves, according to Straub, the existential need of coping with contingency. The existence of (narrative) patterns which can be applied in the encounter with new, unforeseen situations is a precondition for agency since this enables us to see meaningfulness and even causality, which we can master, rather than chaos. But it is evident that the stabilizing function of narrative patterns is but one side of the coin of subjectivity and agency. It is equally crucial to adapt and "update" the narrative order of things constantly in order to be able to integrate changes and to react adequately in varying situative frameworks.

Here, the idea of two main features of narrative operations - reconstructive and deconstructive - becomes manifest, since they represent the two complementary functions of narrativity for a subject's coping with a constantly changing reality: The reconstructive operations represent the capacity to construct stabilizing frameworks and patterns, which help to stabilize existence "in time", whereas the deconstructive operations represent the capacity to re-organize and adapt these patterns similar to "reflexive distance" according to Straub's terminology. Reconstruction and deconstruction both apply when it comes to the identification and selection of relevant aspects of the past, when it comes to historical narratives and when it comes to the ways the past is linked to present and future. This is mirrored in the 6-field matrix of historical consciousness by Hasberg and Körber: 
Table 1. The 6-field matrix of historical consciousness.

\begin{tabular}{|c|c|c|c|}
\hline & I & II & III \\
\hline & $\begin{array}{l}\text { Focus "past" } \\
\text { (hypothetical) } \\
\text { "ex func" } \\
\text { ascertain features } \\
\text { of the past }\end{array}$ & $\begin{array}{l}\text { Focus "history" } \\
\text { "ex post" } \\
\text { transforming past } \\
\text { things to history }\end{array}$ & $\begin{array}{c}\text { Focus } \\
\text { "Present/Future" } \\
\text { "ex nunc, pro nunc" } \\
\text { connecting things } \\
\text { past and history } \\
\text { to the present and } \\
\text { the future }\end{array}$ \\
\hline \multirow{3}{*}{ 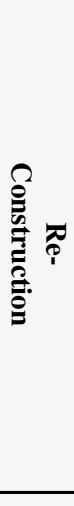 } & $\begin{array}{l}\text { Reconstructing } \\
\text { "occurences" } \\
\text { and "facts" from } \\
\text { original sources }\end{array}$ & $\begin{array}{l}\text { Contextualizing } \\
\text { "particles of the } \\
\text { past" } \\
\text { - synchron: } \\
\text { structures } \\
\text { - diachron: } \\
\text { developments }\end{array}$ & $\begin{array}{l}\text { Constructing connec- } \\
\text { tions of causality } \\
\text { and of meaning } \\
\text { between past facts } \\
\text { and incidents to } \\
\text { present and future }\end{array}$ \\
\hline & \multicolumn{3}{|c|}{$\begin{array}{l}\text { Synthetical (re-)construction of chronological meaning } \\
\text { (a narrative story) from material }\end{array}$} \\
\hline & \multicolumn{3}{|c|}{ OPERATIONS OF HISTORICAL CONSCIOUSNESS } \\
\hline \multirow{2}{*}{ 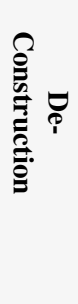 } & \multicolumn{3}{|c|}{$\begin{array}{l}\text { Analysis of the narrative construction of a narration, } \\
\text { determine its way of constructing historical meaning }\end{array}$} \\
\hline & $\begin{array}{l}\text { Detecting "facts" and } \\
\text { incidents of the past } \\
\text { from narrations }\end{array}$ & $\begin{array}{l}\text { Analyzing contextu- } \\
\text { alisations inherent in } \\
\text { a narration (syn- } \\
\text { chron and diachron) }\end{array}$ & $\begin{array}{l}\text { Analyzing narratives } \\
\text { regarding to their } \\
\text { offers for orientation } \\
\text { in present and future }\end{array}$ \\
\hline
\end{tabular}

(Hasberg/Körber 2003. See also the contribution by Körber in this volume for an elaboration of the matrix of historical consciousness)

Thus, the idea of narrative competence combines the ability to reconstruct "events in the past", historical narratives and interpretations linking the past to the present and future and the ability to "read"/ understand the inner logic of historical narratives and interpretations established by others, as well as to identify the elements of "past events" they consist of and the ways these events are represented (Schreiber et al. 2008). 


\section{How to operationalize these theoretical thoughts?}

The didactical concept "One history - many stories" was developed at the Center for Studies of Holocaust and Religious Minorities in 2007 as an element of a course for school teachers. Since then the concept has been re-used in the context of a bi-national (German/Norwegian) seminar with pupils between 18 and 20 years of age. In this presentation, I will focus on the outcome produced by the use of the concept within the teacher course.

The concept of the course is based on the assumption that the national master narrative about the German occupation of Norway constitutes an important point of reference in the historical consciousness and, not least, in the teaching practice of all participants of the course (due to its continuing predominant presence in history textbooks). At the same time, we assumed that this narrative would be interwoven with - or interfered by - other narratives about the period. The aims of the course were as follows:

- to make the participants aware of the different narratives they were carrying;

- to give them tools to identify and reproduce (reconstruct) as well as "read" (deconstruct) different narratives in a public exhibition;

- to operationalize these tools into elements of history teaching.

\section{The teacher course}

The participants of the course were 25 teachers, mostly teaching at an upper secondary school level. The presentation of the participants showed that most of them currently live and teach in the southern part of Norway, but that more than half of them grew up in other parts of Norway. One participant had a German background. In order to create an "opener" to the subject of the course and an awareness of the different personal narratives which the participants relate to regarding the history of WW II, they were asked to present themselves in the following way: "Tell about your first encounter with the history of World War II."

The stories told in this first presentation showed a great deal of diversity, not only according to the participants' regional and local background, but also in relation to their age and gender. None of the participants was, of course an "eye witness" of the war in terms of having experienced it consciously. But several members of the group had grown up in the immediate postwar years, and these persons tended to tell stories from their own family's war experiences and the traces the war had left on their childhood. The younger participants, though, retold stories 
from the war which they had heard via the media, school or older family members. And some of them commented on the impressions these stories made on them as youngsters - a de-constructive operation, showing some cognitive and emotional distance to the topic of war. There was an interesting, though typical gendered difference in the stories presented by the participants. Quite a few of the male participants with different generational and regional backgrounds told stories reflecting the fascination of military events and material remains, such as bunkers that boys would use for war games after the war, while none of the women contributed stories of this kind.

After the presentation, a lecture was held, introducing the changing scientific and public focus regarding the history of the German occupation of Norway. It was also shown how the ongoing investigation of phenomena related to the years 1940-45 coincided with a growing attention for the question of how this past has been dealt with and remembered after 1945. This tendency to "historicize" postwar memory culture was related to the concept of historical consciousness and its basic assumption that any reference to the past emerges from contemporary needs for orientation. The question was raised, which consequences this would have for history teaching concepts. Could the awareness that the history of WWII has been perceived and interpreted differently in different periods of the postwar era, and by different groups, contribute to the competence of critical and (self-)reflective evaluation of historical accounts and cultural representations of the past? Some of the participating teachers remarked that these ideas corresponded very well with Norwegian history curricula, which focus more on critical judgment and the competence to relate past and present than on canonized factual knowledge.

After this introduction, the whole group was taken to the Norwegian Resistance Museum, where they worked in the exhibition in smaller groups. This exhibition, created in the early 1970s by resistance veterans, can be regarded as a materialization of the dominating national narrative about WWII (as presented in the beginning of this article). On the one hand, the exhibition has a chronological structure which seems to tell the "whole story" of the five years of occupation. On the other hand, it breaks with chronology and focuses on the different forms of civil and military resistance and the German repression against it. By leaving out or at least not focusing on the "grey zones" between patriotic struggle and collaboration/ treason, the exhibition creates the impression of a "nation-in-resistance", created by the occupation, where coping with rationed food, wearing forbidden national symbols and fighting against the German occupiers were just different points on a scale of a "good Nor- 
wegian's" behavior. ${ }^{1}$ In this way, the exhibition displays a straightforward national narrative, reflecting a certain perspective, namely, the perspective of the veterans as it emerged in the 1970s. It is this narrative which has been extremely modified by scientific and public debates since then, as presented earlier. The question follows how visitors whose historical consciousness is informed by contemporary history culture and different personal backgrounds will read and interpret the exhibition? It may well be that it displays so many aspects and such a multitude of material (written sources, pictures, objects from wartime, models, and commenting texts) that the visitors have the opportunity to select aspects and re-arrange them according to their personal experiences, imaginations and meanings, this past carries for them.

In order to facilitate an approach allowing the participants to use their own background in reconstructing the history of The Second World War, we divided the seminar group in sub-groups of three or four, handed out a digital camera to each group and gave them the task to create a mini-exhibition consisting of four images taken in the exhibition. ${ }^{2}$ These mini-exhibitions were required to address one of the following propositions:

1. Tell the story of the years of occupation as it is told in the exhibition.

2. Tell the story of the occupation as it is best known to you.

3. Tell the story of the occupation as you think it should be told.

In terms of narrative competence, the three tasks aimed at the identification and reproduction of the exhibition's narrative, at production/construction of personal narratives and, last but not least, at the reflection and deconstruction of both the exhibition's narrative and their own.

After the visit to the Norwegian Resistance Museum the whole group returned to the HL-center where each of the groups presented their "mini exhibition" (the text below is the transcript of the three presentations given). Each presentation was followed by questions and comments from the other participants. This presentation and the subsequent discussion was an important part of the learning process regarding a focus on the de- and reconstruction of historical narratives. Confronted with the ways the other participants had solved the task in the museum and the multitude of "war narratives" generated, the participants became more aware of the choices they had taken. This self-reflexivity relating

1 For the exhibition's contents see: http://www.mil.no/felles/nhm/start/eng/.

2 All photos in this article are the property of HL-senteret and the Norwegian Resistance Museum and were kindly made available for use in this publication by Samantha Maurer Fox. 
to the multi-layered character of possible historical narratives is an important starting-point for an active participation in the permanent negotiations about the ways the past can be told, interpreted and used - regardless of whether it applies to family, local or national histories.

These are the results of three of the groups which chose one of the respective tasks: 


\section{The national narrative}
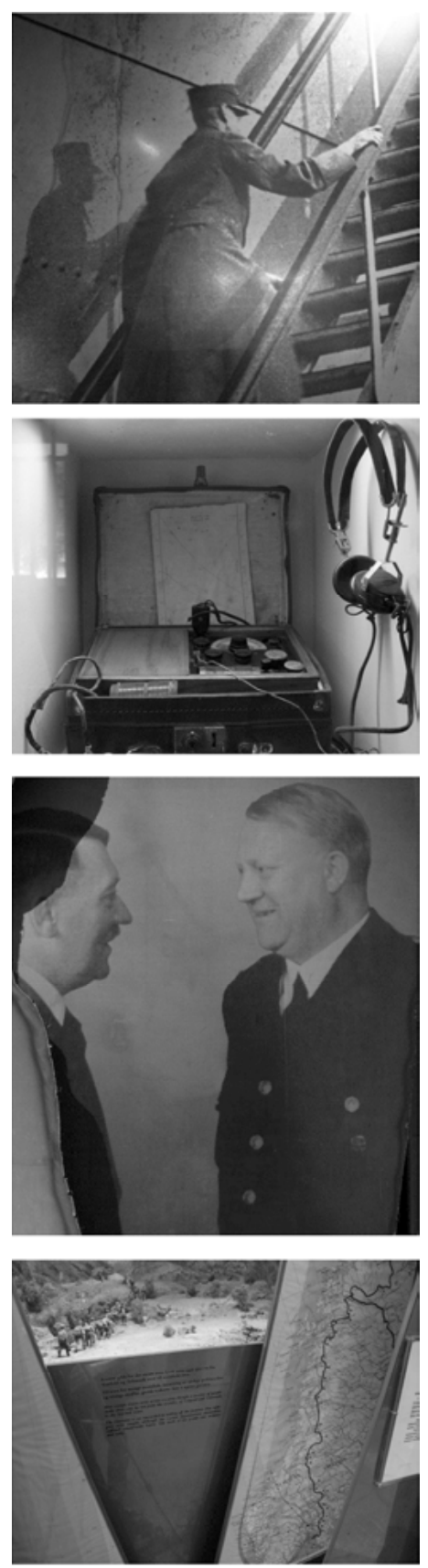

"K1: 'Yeah, this is picture no. 1, King Haakon leaving Norway on June 7th, 1940 to continue the fight from England. [He] was the head of the Norwegian resistance struggle for two months, and we thought this was a fitting image [...]

Yeah, resistance struggle. This is a picture of a concealed radio transmitter. One of the most important tasks of the Norwegian resistance struggle was to collect information about German positions, German ships etc., and to send the information to England.

This image may be of poor quality, but [telling] about the resistance struggle without mentioning Quisling is not an option. Quisling was the very symbol of Nazism in Norway.

[...] There were many who fled from Norway, some to Sweden, as the arrows at the border show, and many others who travelled westward. And below in the picture there is a long red stripe [...] in that direction. Those were the ones who went to the Shetlands, to Scotland, to England, or in that direction. And there were different reasons why people left for either Sweden or the West. It could be in order to join the resistance struggle, or it could be because they had to escape from the Germans, because they perhaps had participated in something."”

In this group, the reconstructive mode of dealing with the material is predominant. Not altogether surprising since the group explicitly chose the task to reproduce the story about the war as it is told in the exhibition. 
The participants selected four images which represent events, agents or, in a broader sense, phenomena from the war which they regard as elementary and they arranged them in a way which creates a linear story. In this way, the "focus past" and "focus history" - meaning, the focus on single aspects/events of the past and the focus on the narrated and interpreted past as shown in the figure above - are combined. The reconstructive way of dealing with the focus past is evident, when each picture is explained by giving an outline of the historical event it represents, or in the case of Quisling, explaining, that he symbolized betrayal then, which also is a way of reconstructing the past. The arrangement of the four pictures has no chronological, but a logical order following the pattern of public memory and history writing in the postwar era. The framework is the notion of "national resistance", which is first and foremost represented by the king, who, before leaving the country in order to continue the struggle abroad, fought together with his countrymen. There is no deconstructive element which might consider other interpretations of the king's decision - e.g. that he abandoned his countrymen, leaving them to their fate, while getting himself to safety.

The logic of the narrative of the king and "the people" fighting for the same cause is continued with the second and fourth image, which represent one branch of resistance activities, namely the transmission of sensitive military information to England and the consequences resistance activities had for many Norwegians, namely, being forced to leave the country. Both images are connected to the first one by taking up the notion of "England", and by doing so combining not only the struggle at home and abroad, but also, again, the king and "his people". The second image exemplifies the antipode to the national unity which is represented by the other images. There is no further information, no narrative elaboration of Quisling as a historical agent. This image has, thus, no function related to the "focus past" (which means, the focus on single events in the past) but only to the "focus history" (which means the focus on an overall narrative, structured by a certain pattern of historical meaning). ${ }^{3}$ It serves as a marker for "the other side", which constitutes (alongside with the Germans which are mentioned in the second and fourth image) the unity of the people, with the king as its "the head".

As mentioned before, we do not find any deconstructive elements in this presentation, neither related to the "focus past", the single events

3 Jörn Rüsen (1983) suggests four "ideal" types which structure historical meaning - a traditional, a genetical, an exemplaric and a critical mode which differ in the way past, present and future are linked together. Narrative patterns, such as e.g. "everything used to be better" or "we learn from the mistakes of the past" reflect the different types of historical meaning. 
which are reported (could there be alternative stories, interpretations?) and represented in the images (who has produced them and when, which might have been the intention, what do they tell, what not etc.?) nor related to the "focus history". The story which is being told here can be described as a "royalist" version of the national narrative. There were many different motivations to participate in resistance activities, and enquiring into them and the alternative narratives they would constitute, would have been one possibility of integrating a deconstructive perspective in the presentation.

Another dimension of narrativity left out in this presentation is the "focus present/future". Nothing is said about the meaning this story about national unification in and through resistance could have today, neither in a re- or deconstructive way.

So, one could ask whether the task for the group should have been formulated in such a way as to not only encourage them to reconstruct the museum's narrative, but also to reflect on the premises of this narrative. Nevertheless, when thinking about using the teaching concept in a school context, this task seemed to show that narrative competence can be fostered on a basic level.

The second example I would like to present is far more complex, when it comes to the different foci and narrative operations. 


\section{Deconstructing the national ...}
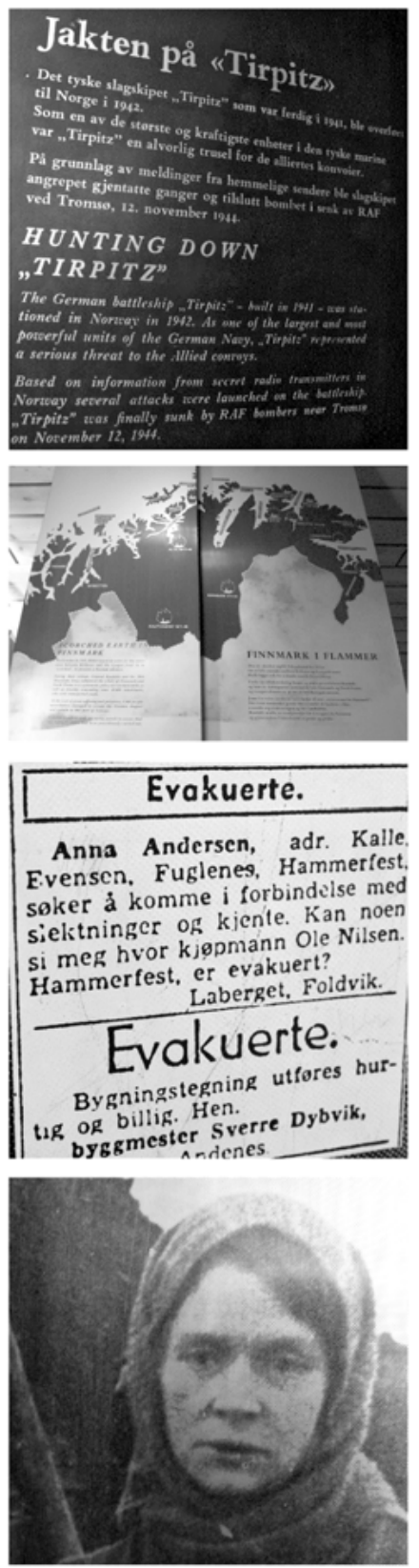

"P1: 'We've found out that we pretty much come from the same background [...] We're the 'Finnmark bunch'. So, we chose that as an approach, this was the idea in the beginning. Just tell about the four pictures. The first image is named 'Hunting down Tirpitz', the other 'Finnmark in flames'. For the third we took a picture of a notice in a newspaper, in which an evacuated woman from northern Norway is searching for people she knows. And the fourth image is a woman from the coast some place in Finnmark or North-Troms, with a scarf and somewhat vacant eyes. What did we think? Well, we thought we would take this perspective, this Northern Norwegian perspective, and try to look at it starting with what we were told when we grew up.'

[...]

P2: 'Ok. A little bit about what we talked about while we walked around there. I remembered having a teacher when I studied history [...] who worked at the Institute for Defense Studies at that time. I can just remember that as a very young student I was embarrassed when he said: 'Norway felt it was raped, Norway had no experiences with the cruelties so familiar out there in Europe through the centuries.' And when we focus too much on the burning of Finnmark and North-Troms, and say that it was so terrible, that just shows how we look upon WWII, that we make such a big thing of it. In no other country were there so many books written about WWII as in Norway, he said. I was somewhat embarrassed, but not too much. But I said the same to my mother later, that the focus on the burning of the 
North had become so big in our eyes. Then, she got very angry and left the kitchen table. But what [this teacher] meant, was probably that you cannot compare suffering, or what people have experienced, or personal pain. But he meant that seen from Europe's experiences with the madness, the madness of war in Eastern Europe, Flanders and the North of France, the refugees from the east who came in the days of January 45, the German refugees, and all the personal tragedies and experiences [...]. Well, if I, as a teacher, would present the burning of Finnmark and my family's personal histories in that broader perspective, then that would certainly have an impact on my pupil's views. They would encounter a history narrative which now maybe has a somewhat different perspective."”

This group had chosen the task to represent the story about the war as they know it best. They introduce their perspective and their narrative angle as being framed by their personal background, which means, coming from Finnmark in Northern Norway. This is the obvious selection criterion for the four images which are presented. All of them represent events which had happened in this region and so the choice combines a narrative reconstruction of events in the past as well as the reconstruction of a chronological historical narrative: The military confrontation between German and allied troops represented by the "Tirpitz", followed by the "scorched-earth" policy the Germans carried out when retreating from the North and the traumatic consequences that forced evacuation had for the civilian population. The group makes a clear statement about their deconstructive aspiration when saying that they wanted to find out what was told about the North at all in the Resistance Museum. Indirectly, this is a statement about the predominance of another, the dominant national narrative in the museum and the attempt to construct a "counter-narrative".

The sequence where P2 tells about her experience of meeting a university teacher who embarrassed her at first and then seemed to have broadened her scope of historical thinking is a very interesting mixture of re- and deconstructing operations. Here we have a personal narrative which points to the speaker's personal background and the way memories about the war were transmitted in her family. The teacher's comparison of Norwegian suffering during the war with the far more traumatizing experiences of other countries first embarrasses her, but is then described as some kind of eye-opener due to the fact that war history may have become "oversized" in the national - and regional - memory culture. Here, we find a deconstructive attitude related to the "focus history". When telling about her mother - who probably has experienced the traumatic events herself and who reacts angrily - the speaker also introduces the notion of generation-specific attitudes towards history. She 
ends her statement with a call for multi-perspective approaches towards history, in which her familiar and local background would inform one of different voices (another would be the "European perspective") when teaching about the war.

Afterwards, the next speaker turns back to the images the group has chosen and starts to reconstruct the story of the events relating to them:

\section{and reconstructing the local}

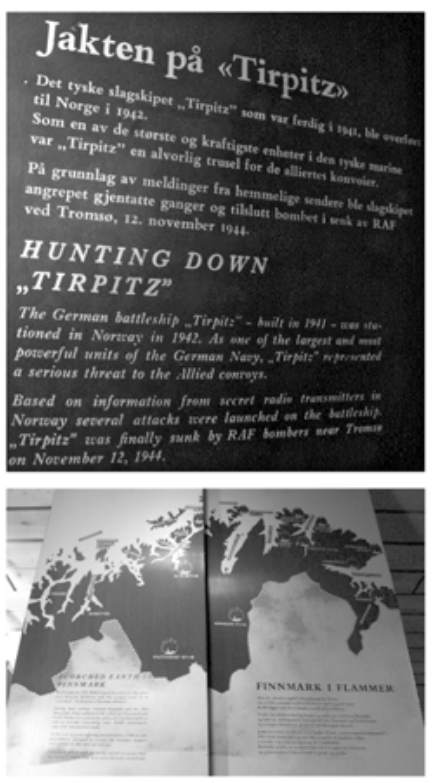

Evakuerte.

Anna Andersen, adr. Kalle Evensen, Fuglenes, Hammerfest soker a kome i forbindelse med kiente. Kan noen siektninger of kichn Ole Nilsen si meg hvor kjopmann Hammerfest, er evakuert. Foldvik. Evakuerte. Bygningstegning utfores hurBygning of billig. Hen.
byggmester Sverre Dybvik,
"P1: 'I want to say something concrete about the four different pictures. This one about the 'Tirpitz' is a side of the war, of the occupation, which had a very strong impact on the people from the coast in Finnmark. The 'Tirpitz' had a vital function for the Germans in connection with the convoy traffic in the North, and staying in contact with the maritime areas in the North was very important. What you also mentioned is that the 'Tirpitz' and the remains of the 'Tirpitz' up there have a crucial meaning in people's ideas about the war [...] yeah, even the popular description of the war. In textbooks, this perspective is not integrated at all. And what we needed was also [...] we should try to use our background to $[\ldots]$ highlight $[\ldots]$ what the Resistance Museum has focused on. Find out how much of Finnmark's history is mentioned. And we almost had to go through the whole museum before we found anything about Finnmark [...].'

P3: 'I heard somewhere that there was a place [...] which a German soldier refused to set fire to, and it was not destroyed. And he came back after the war and was a very respected man there. Do you know something about this? This is an example for, for [...] what shall I say,

for resistance that existed also on the German side. There really was something like that, in fact.'

P2: 'There were quite a few churches that were spared. They were not burnt down.' 
P4: 'When it comes to East-Finnmark, very little was destroyed there, because they came in a hurry. So, one will find a lot left there. Because East-Finnmark was occupied by the Russians. [...] In the West, the Germans had more time, and there more or less everything [was burnt] apart from churches which stood on graveyards. They were spared. But nothing else [...].

In some way [all this] is very essential for us who have relatives, parents, uncles, aunts who were affected by this history of the evacuation. This was the war, because it happened under totally extraordinary [...] conditions. Especially regarding hygiene and health. Babies born [...] on a little fisherman's boat with 50 people where the sanitary conditions were really bad. Such things are part of the whole story.",

Interesting in this sequence is how we do not get a "complete" narrative about what happened with the "Tirpitz". Instead, the speaker makes many allusions and he seems to take for granted that the audience knows. In memory research, this way of introducing a story without telling and instead dropping some "key words" is called narrative abbreviation. Obviously, the "codes" of common local memories worked for the members of the group and they stuck to them when presenting their work to the rest of the seminar group. This differs from the way the stories about the burning of the Finnmark are told. Here we even get a chronological description (first, the Germans' haste in the Eastern part, then the complete destruction of the Western part) and even a detailed story about an individual German's refusal to follow his orders to burn down a town. We are not told which sources these narrative reconstructions are based on, only in one case is the speaker open about the fact that he is not sure about the details and asks the group for support ("Do you know something about this?"). Still, in the last sequence it is made clear, that family stories and, thus, memories transmitted in the group members' own families represent an essential source for their knowledge about and views upon war history.

This leads again to the deconstructive attitude the group has towards the exhibition of the Resistance Museum. It is obvious that this exhibition is regarded as representing a dominant, national narrative, which the speakers think is also transmitted in textbooks, where "this [the Finnmark] perspective is not integrated at all." The confrontation of this narrative with the group members own, Northern Norwegian narrative is interpreted as an avenue to "read" the exhibition in a different way:

"And what we needed was also [...] we should try to use our background to [...] highlight [...] what the Resistance Museum has focused on. Find out how much of Finnmark's history is mentioned. And we almost had to go through the whole museum before we found anything about Finnmark." 
Reconstructing one's own and deconstructing a dominant narrative go hand in hand here, but the exhibition still provides the material (images, texts) which can trigger the alternative narrative. Only speaker P2 directs a deconstructive attitude towards this "own", regional narrative and she is also the only one who touches upon the focus "present/future" when talking about how to teach war history today.

The last example I would like to present here shows a completely different dynamic than the other two. The group chose the task to "Tell the story of the occupation as you think it should be told" and it solves the task almost without resorting to operations of reconstruction - be it related to "events" or "history". 


\section{An "ideal" way of teaching history}
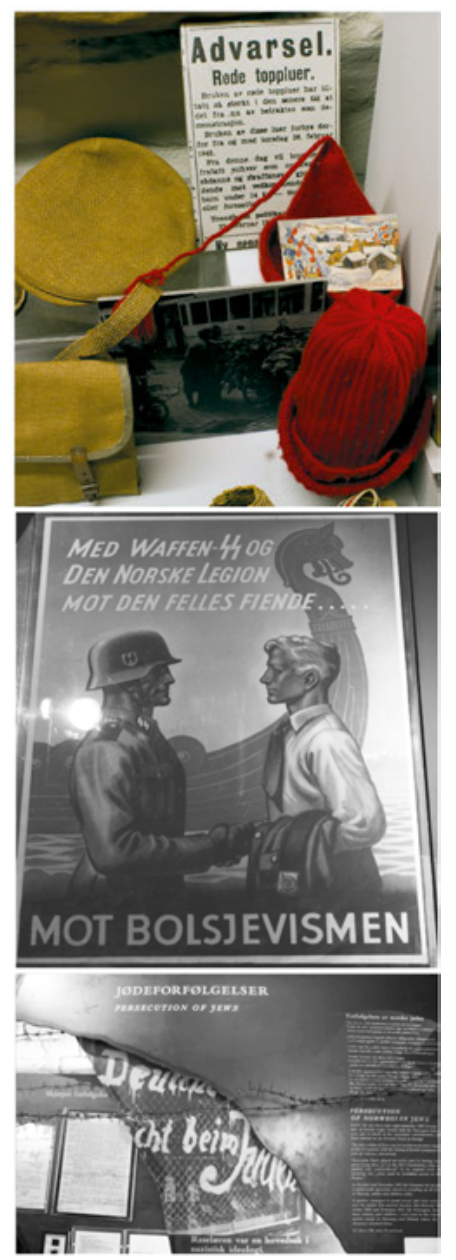

"We first chose the red cap [nisselua], of which there is a picture, which was in a display case about everyday life. And there we thought about this with empathy, that both things and images can be a starting-point for getting interested into how everyday life was in Norway during the occupation. Anyway, I personally think that one should devote more time to this Norwegian perspective, and then build up empathy to get pupils interested in what happened.

And then we had a poster, a propaganda poster. It was that one about the Bolsheviks, with a Viking boat, a Norwegian and a German who were going to fight Bolshevism. And we chose it for the critical perspective it offers, to understand propaganda, which means: history being instrumentalized for persuasion, and that pupils become aware of this in different contexts, not only directly related to propaganda posters, but also when one reads textbooks, sees films [...]. So we learn to use our critical mind which you acquire when you work in that way. So, related to all media they are confronted with. We spent a lot of time with [teaching] this, and we were successful. I see they have become more critical now, also in other subjects than history. Who wrote this, and how did he get such an idea and so on.

And then we chose a picture of [...] yeah, there were Jews and it must have been from the Warsaw ghetto. We had a question mark concerning images of Norwegian Jews, and exact numbers. There was something written there, but we thought there was something missing there, that this is also important for the pupils. They have a tendency to [...] that it is something which happened far away, even if they have information and read stuff about events which happened here at home. But still they don't manage to relate to it, in a Norwegian perspective. This is also very important. This starting-point. They could, for instance, follow a Norwegian Jew on a path where many others went. How 
Norwegians in general reacted when the Jews were deported [...] They didn't say much about that here.

So we had our fourth image, which was taken from [the newspaper] $A f$ tenposten. There was a headline "Hitler attacks", it must have been about Poland in 1939. We chose this image because of its usefulness for source criticism. [We try] all the time to get original newspaper clips, authentic objects and so on and use them in history teaching. When they get something concrete and physical, things become more meaningful for them. I thought about the issue of facts [...] living together with facts all the time, this is a challenge, something you must have in the back of your mind all the time, regardless which methods you use. And pupils can use this also in relation to other subjects."

It is obvious, that the group does not tell "the story of the occupation" but, instead, starts a meta-discourse on how to teach history, which media to use and how. But the group definitely is also concerned with the contents of history teaching and, in this way they cannot do completely without narrative elements. I would like to illustrate this with two examples:

1. When talking about how propaganda material from WWII can be used to strengthen a critical perspective on manipulative techniques, the speaker sums up very quickly what is shown on the poster: "[...] a Viking boat, a Norwegian and a German who were going to fight Bolshevism." This is, again, a narrative abbreviation. It alludes to the whole narrative which motivated and legitimized Norwegian young men's voluntary participation in the German warfare. It links the pan-Germanic project of the Nazis back to the "heritage" of the Vikings, making the fight against Bolshevism (and, implicitly, the planned "Germanic colonization" of the east) appear as a logical continuation of the Vikings' expeditions to the Black sea. The "critical" approach to the means of propaganda which the group claims here, points to re- and deconstructive competences, namely the competence to identify the propagandistic choice of highlighted elements in the past, the constructions of historical narratives of tradition and heritage and their exploitation for the interested party's own ideological purpose.

2. The second example is the presentation of the part in the exhibition dealing with the Holocaust. Here, the approach is deconstructive: What is told, what is missing? The speaker sees the Norwegian perspective lacking in the presentation of the situation of the Jews- which is arranged around a very popular image from the Warsaw ghetto uprising (an icon of Holocaust memory). The speaker states "They have a tendency to [...] that it is something which happened far away, even if they have information and read stuff about events which happened here at 
home. But still they don't manage to relate to it, in a Norwegian perspective." This, again, alludes to the question of narrative competence. What the speaker is saying is that historical consciousness about the Holocaust is disconnected from historical consciousness about Norwegian occupation history - it is not integrated into the national narrative about the war. Interestingly, he stresses that this is not only caused by lack of knowledge. So, the didactical challenge he describes here lies in the competence to integrate the different narratives.

\section{Conclusion}

The presentation of the ways in which the participants of the teacher training used the exhibition of the Norwegian Resistance Museum in order to create narratives of their own has shown that various aspects of narrative competence can be triggered by the method of letting learners create narratives which take a starting-point in, are inspired by or just take their material from a historical exhibition. The examples above have shown that the participant's capacity to relate to the museum's exhibition as a narrative has been fostered, which includes the awareness of the fact that the exhibition represents one of many possible narratives about the time of the German occupation. This creates a distance necessary to address questions of history culture, historical culture and hegemony, and perhaps an increased open-mindedness to marginalized versions of this particular history.

Related to this open-mindedness, and maybe even more important than the reflection about the exhibition in the light of the concept of narrativity, is the participants' deepened awareness about their own ways of dealing with the history and memories of World War II. They have been challenged to become aware of their individual ways of addressing this aspect of the past and how these individual narratives are related to other, local, national and even universal interpretative frameworks. It is here, that the effect of self-reflexivity is reached, the capacity to address one's own historical interpretations as something which also could be different, which would be different under different conditions.

The different tasks related to the exhibition offered possibilities to either work with the exhibition in a reconstructive way - creating own narratives - or in a deconstructive way - investigating existing narratives, both one's own, those of the other participants and public/official ones. It seems that the presentation and discussion of the results of the group assignments for the entire seminar group contributed to the participants' readiness to handle these different modes of creating and critical- 
ly investigating the narrative ways in which meaning is attached to the past.

As a last thought, I would like to highlight the potential of using this teaching tool in the context of intercultural learning. One could provokingly argue that already the effect of discovering the local sub-layers of the national master narrative and the identity of "good Norwegians" related to it had the character of an intercultural encounter. Here, definitely, quite diverging memory cultures related to World War II emerged. Not to speak of the perspective of the participant with a German background and the German memory culture and coming-to-terms with the history of the Nazi era as an informing background. One can imagine that this kind of work with the exhibition of the Norwegian Resistance Museum would have been quite interesting with more participants with immigrant background, European and non-European. In which ways would Pakistani-Norwegian working immigrants or refugees from war and genocide have used the material from the museum exhibition in order to create "their" narrative? Since the concept has a potential to create, or enforce awareness and critical self-reflection of historical narratives it could be used to trigger a dialogue about the ways in which public narratives contribute to group identities, creating the feeling of belonging or exclusion. It could be the starting point of a dialogue about how an inclusive history culture could look like, inviting all members of society to create and articulate their own ways of "making (narrative) sense" of the past.

\section{References}

Ericsson, Kjersti/Simonsen, Eva (eds.) (2005): Children of World War II - the hidden enemy legacy, Berg Publishers, Oxford.

Eriksen, Anne (1995): Det var noe annet under krigen, Pax, Oslo.

Flacke, Monika (2004): Mythen der Nationen. 1945 - Arena der Erinnerungen. Begleitbände zur Ausstellung des Deutschen Historischen Museums, Philipp von Zabern Verlag, Mainz.

Hasberg, Wolfgang/Körber, Andreas (2003): "Geschichtsbewusstsein dynamisch”. In: Andreas Körber (ed.), Geschichte - Leben - Lernen. Bodo von Borries zum 60. Geburtstag. Forum Historisches Lernen, Wochenschau Verlag (Forum Historisches Lernen), Schwalbach/Ts, pp.177- 200.

Lenz, Claudia/Moller, Sabine (2006): "Die Gegenwart in der Vergangenheit: Gruppendiskussionen über den Zweiten Weltkrieg und den 
Holocaust in (Ost)Deutschland und Norwegen". In: Psychologie \& Gesellschaftskritik, 118, 30(2006), pp. 57-81.

Lenz, Claudia (2007): "Vom Widerstand zum Weltfrieden. Der Wandel nationaler und familiärer Konsenserzählungen über die Besatzungszeit in Norwegen". In: Harald Welzer (ed.), Krieg der Erinnerung. Krieg der Erinnerungen. Holocaust, Kollaboration und Widerstand im europäischen Gedächtnis, S. Fischer, Frankfurt am Main, pp. 4176.

Lenz, Claudia/Welzer, Harald (2007): “Opa in Europa. Erste Befunde einer vergleichenden Tradierungsforschung”. In: Harald Welzer (ed.), Krieg der Erinnerung. Krieg der Erinnerungen. Holocaust, Kollaboration und Widerstand im europäischen Gedächtnis, S. Fischer, Frankfurt am Main, pp. 7-41

Lenz, Claudia (2008): “Gedenkorte als Laboratorien histoischer Sinnbildung: Geschichtspolitik, öffentliche Erinnerung und individuelle Erinnerungs-Skripte”. In: Harald Schmid (ed.), Geschichtspolitik und kollektives Gedächtnis. Erinnerungskulturen in Theorie und Praxis, V\&R unipress, Göttingen, pp. 199-228.

Levy, Daniel/Sznaider, Natan (2005): The Holocaust and Memory in a Global Age, Temple University Press, Philadephia.

Maerz, Susanne (2007): Die langen Schatten der Besatzungszeit. 'Vergangenheitsbewältigung' in Norwegen als Identitätsdiskurs (= Nordeuropäische Studien; 20), Berliner Wissenschaftsverlag, Berlin.

Rüsen, Jörn (1983): Historische Vernunft. Grundzüge einer Historik I: Die Grundlagen der Geschichtswissenschaft, Vandenhoeck \& Ruprecht (Kleine Vandenhoeck-Reihe; 1489), Göttingen.

Straub, Jürgen (ed.) (2005): Narration, Identity and Historical Consciousness (Making Sense of History, number 3), Berghahn Books, New York. 


\title{
How to Examine the (Self-)Reflective Effects of History Teaching
}

\author{
BODO VON BORRIES
}

In many countries the public and the political authorities strongly insist on standards and large scale evaluation (using high stake testing). In this concept, a school subject without precisely controllable and selfevidently useful achievements - especially for future employment does not merit learning time at school. This is fashionable, but merely a so-called mechanism to please everybody. Simple testing of historical competencies is an illusion, it promises more than can ever be effected.

In contrast, many progressive critics (e.g. teachers and educators at memorial sites) deny and refuse any time-saving, objective and efficient evaluation of learning processes in history. They express their deep conviction that the mania of objective tests is damaging (self-)reflective historical learning. This scepticism of evaluating historical learning processes is just as bad - and as risky for historical learning as standards and large-scale evaluation might be, as long as it means that more elaborated tests are not developed and tried out. If there are no measurable effects, history may vanish from the future obligatory syllabi. Any communication between supporters and critics of evaluation seem to have totally stopped in some countries. Here both parties have to return to the common table and learn together.

Obviously, learning history is everything but copying and pasting of information about the past into the students' minds. It is rather the individual interpretation of the relation between past, present and future within social frameworks, which are relevant for an individual's and a group's orientation in life. Teaching history in a (self-)reflective way 
does not mean teaching (nor enforcing) special knowledge, conclusions, opinions and attitudes, but stimulating and promoting participation in the culture of history (using [re]presentations of history), building one's own historical identity (definition of self and groups in the course of time) and improving one's historical competence (developed abilities and willingness of thinking historically) (see Körber et al. 2007; Schreiber/Körber 2006) ${ }^{1}$. The result will and legitimately may be different for every individual, for instance among thirty seventh-graders in a common classroom. This is obvious, but seldom seriously taken into account by history teachers.

How does one evaluate, examine, and differentiate such a complex and ambivalent learning process? The long-term effects and the real behaviour in future life cannot be measured exactly, but only predicted hypothetically to a certain, rather low degree. The limitations of multiplechoice questions and of paper-pencil tests in general in evaluating historical competencies are narrow, though potentially much wider than the actual practice of testing in many countries (comp. chapter 2). Indeed, differentiated tests employ more intelligent formats like allowing a choice of alternative answers, production of mental maps or writing short essays, which are able to diagnose special figures and logical steps of thinking historically.

Nevertheless, the combination of insights, emotions, conclusions, and activities, which are typical for the entire process of historical learning, can only be evaluated by observation of students' (re-)actions in similar situations or conflicts. Competences are transferable - but domain-specific - abilities of finding and solving problems in future life. There is no possibility to evaluate them other than by simulating new (hypothetical) problems of a similar type to those the student has already solved and by making the student work and act in them. In the following paragraphs, this will be explained by examples.

The argumentation will proceed in four steps:

- Explanation of the preconditions of testing (self-)reflective historical thinking,

- Examples of traditional (anti-)reflective history tests,

- Examples of alternative testing approaches to second order concepts in history,

- Examples of innovative testing methods for the evaluation of dealing with history.

1 For elaboration of the theoretical understanding of the development of (self-)reflective historical thinking see the contribution by Körber in this volume. 


\section{General approach}

What is the aim of history learning? Since the 1970s, German tradition and theory has been pointing to an elaborated historical consciousness (Jeismann 1985; Rüsen 1994a; Rüsen 1994 b; Schreiber 2003). But what does that mean? Is there any chance of operationalizing the concept of historical consciousness, which will be a necessary precondition of diagnosing and measuring? Other concepts which seem to emerge with strength and conviction in the debate, are historical identity, historical competence and historical culture (or better: culture of history), as well as politics of history, identity management and places of remembrance. This requires a small theoretical remark: To me, "historical consciousness" remains the key concept and the general expression to be used (Borries 2008a:4ff; 2008b). Therefore, the crucial objective is to create "reflecting and (self-)reflexive historical consciousness" (see references above) of which three dimensions can and should be distinguished:

- "Historical identity" means the self-definition of an individual or a group (city, gender, class, profession, nation) between interpreted past, perceived present and expected future. It is the construction of sense and continuity (persistence in change) in the course of time and its contingency (more than accident, less than necessity). It needs to be added that knowing and understanding otherness (alterity) and foreign behavior and identities is part of the process of evolving one's own identity. ${ }^{2}$ Every identity has a narrative and a historical structure (Borries 2004. 259-287; Ricoeur 1988/89/91), but not all histories told by individuals or groups are sufficiently plausible or even plausible to a higher degree (Rüsen 1983: 85-136). The inclusion of verified primary sources from different sides and of different points of view of the present etc. improves the quality of historical narratives and the chances of communication and agreement.

"Historical competence" is the ability and willingness of thinking historically as one of the main accesses to the world (in addition to a mathematical, a linguistic, an aesthetic, a scientific one etc.). It is the capability and readiness: (1.) to ask historical questions and understand them, (2.) to investigate historical topics and produce historical narratives about them and/or analyze the already perfected histories of others, (3.) to orientate oneself through historical narrations within present and future (reorganizing ones own historical consciousness and the understanding of oneself, the others and the world) and

2 In order to know oneself, a narcissistic glance into the mirror is not sufficient; discovering the world and reflecting one's relation to it helps to position oneself. 
(4.) to store and organize concepts, categories, notions, structures of history (Körber et al. 2007; Schreiber/Körber et al. 2006).

- "Historical culture" is the public and private mode of handling history in presentations, consumption and discourse. Though the individuals decide to a large extent personally on the degree of participation - and non-participation - in historical culture, history culture is basically a social, societal, and communicative phenomenon. Today it is mostly determined by the mass media and their private and profit-oriented market organization. The type of interference of individuals and groups in this field of historical activities (e.g. use, neglect, protest, debate, partisanship, revision) is the third dimension of historical consciousness.

All three dimensions can be operationalized, observed (and sometimes measured) and evaluated (to some degree at least). Normally, test producers think of knowledge only, ${ }^{3}$ but competences are more important in modern concepts of historical learning (Borries 2008; Körber et al. 2007; Schreiber/Körber 2006). Living and showing historical identity and taking part in historical culture are activities too and can be observed and described. But the performance of historical identity and the use of historical culture always need and require historical competence, the second of the three dimensions of historical consciousness. Thus, the main problem will be the diagnosis of historical competences.

Additionally, we have to state that identities and cultures cannot simply be judged by their affiliations. A nationalist does not per definition have a better or worse historical identity than a cosmopolitan. The same is true for conservatives and progressives, rightists and leftists. Visiting museums or being member of a local history club does not have a higher status than watching television or reading historical novels, at least not in a self-evident way. Already thirty years ago, Jeismann (see 1985) distinguished three interdependent and necessary levels of historical learning in any learning process: "historical topic analysis", "historical topic judgement" and "historical value judgement". ${ }^{4}$ Jeismann clarified a peculiarity of the third layer (that is historical value judgement or historical orientation): In this field it is inadmissible to grade the direc-

3 Of course, we have to be careful because of the very wide meaning of the word "knowledge" in English. In German, we may distinguish between special and single information ("Kenntnisse"), the content knowledge in a field ("Wissen") and the general system including methods, insights and reflections ("Wissensformen" in a very comprehensive sense).

4 Rüsen (1994b: 64-73, 164-170) similarly enumerates "historical perception", "historical interpretation" and "historical orientation". 
tion of the decision in its content. Only the quality of argumentation and reflection may be evaluated, because it is important to compare and legitimize a decision contrasting it to other possibilities (Jeismann et al. 1987). This limitation of grading remains very important.

\section{Exclusive focus on knowledge damages (self-)reflective learning}

I will here provide two examples of how the testing of mere historical information can damage (self-)reflective learning. Since 2008, Germany has a "scientific" and "standardized" test - designed by a well-known testing institute in Berlin - for evaluating an obligatory orientation course for foreigners desiring naturalization. This is the direct preparation for a "naturalization test", devised by the Ministry of the Interior. The whole test consists of "multiple choice" items (four possibilities, one correct and three incorrect). ${ }^{5}$ The test was commented by some experts as statistically reliable, but showing no content validity whatsoever. Many items were said to be wrong, ideological, unfair or unimportant. One question reads:

"When did Hitler become Chancellor of the '[German] Reich'?

$1923192719331936 "$

Undoubtedly, this is a technically correct topic - and it is rather simple. What does a correct answer actually measure? Knowing the information about the date - as opposed to the dates of the nearly fatal crises of the Weimar Republic (1923), the summit of the "Golden Years" (1927) and the Olympics in Berlin/Spanish Civil War (1936) - is useful, though not at all important. Without the knowledge of why this was important and what happened involving which actors with what consequences it is "pointless, dead information". Choosing the correct date 1933 in the test does not say anything about the reflections on and the meaning of the date for the person answering the question. With such questions, absolutely no evaluation of the (self-)reflective effects of history teaching takes place.

All questions in the test under discussion are of this type. More than three items only refer to the dates of World War II, even more to the simple fact that the Nazi-regime was a "dictatorship". Only one additional name (Stauffenberg, "assassination attempt") and one additional

5 The whole test was published in many major newspapers, e.g. "Frankfurter Rundschau" (3.9.2008, p. 25-32). 
date (9.11.1938, "destruction of synagogues") are required. In these cases, all false solutions are simply funny "kangaroos". Of course, such tests say nothing about understanding, connections, contexts or reflections. They are simply a control of a superficial - and superfluous naming of history items, of an ability of pretending to know what the public discussion is about. It is mechanical memorizing (i.e. learning by rote - and not really "by heart"). Since such examinations determine the type of preceding instruction ("teaching to the test") they are detrimental to learning history in a reflecting way.

In 2005, a major newspaper ("Die Welt") presented a very similar questioning of average German citizens (Die Welt, 25.5.2005, p. 10-15). Questions were, for instance: "What is meant by the term 'Holocaust'?"; "What happened on 31 January 1933?"; "Who carried out an assassination attempt against Hitler on 20 July 1944?"; "Which was the first country that Hitler Germany attacked?"; "What is the first German republic between 1918 and 1933 called?"; "Who was the last German Emperor?" These are perhaps conventional historical questions (are they really important?), but they are obviously not designed to generate thinking or reflection, judgement or balancing, but a simple - possibly pointless - automatism of stimulus and response.

One can deduce from the publication that the questionnaire is implemented as an open answer format; at least, the percentage of correct answers is reported, but no frequency of particularly erroneous answers. The Holocaust question is answered correctly with "Annihilation of the Jews" by $81,7 \%$, but the name "Weimar Republic" is known only to $52,0 \%$ and the "Take-over of Power by the Nazis" on 31 January 1933 to $48,4 \%$. Poland is mentioned as the first victim of World War II by only $50,2 \%$, Wilhelm II. by $50,5 \%$, and the name of the would-be assassin Stauffenberg by $42,9 \%$.

Nevertheless and astonishingly, most commentators (journalists, bishops, historians, teachers, politicians etc.) expressed great satisfaction about the citizens' "good" level of knowledge. But in fact, the results of

6 In German, the question is phrased in such a way that it leaves open who attacked whom. The question is even worse, because it does not explicitly mention the context of World War II: Before that war, Germany had already launched military attacks against Spain in 1936, Austria in 1938, Czechoslovakia in 1938 and 1939 and Lithuania in 1939. Thus the socalled right answer of the test is quite wrong.

7 This is a very problematic expression - by no means innocent or neutral. Contemporaries and historians debated different concepts like "seizure of power", "transference of power" or "take-over of power". This controversy is not at all taken into account in the test question, which anticipates the solution in a dogmatic way and forbids or hinders reflection. 
this asking for numbers, names, dates and facts without context are very poor (as in all other cases of such type of questioning). This had nothing to do with diagnosis of historical identity and historical competence.

\section{Measuring competences}

Let us look at an example of testing an application of historical methods or insights instead of mere reproduction of information. Hans-Jürgen Pandel (2005: 61-62) proposes a nonsense-caricature ("a drawn joke") with two archaeologists in pith helmets inside an ancient Egyptian tomb, discovering a wall-painting of a man burning a computer. The purpose is testing "consciousness of temporality" and "consciousness of reality". After being taught about ancient Egypt and its type of tomb paintings, the tasks for the pupils (fifth to seventh grade) are: "What is incorrect with the picture? Identify the place where the two men are. In which country are they? Which profession do they have? Name the people who may have drawn the wall-painting. The picture is a joke. Why?"

Pandel hoped that the topic would be adequate for testing "consciousness of temporality" (then versus now/in the future) and "consciousness of reality" (reality versus imagination/fiction). But he experienced - and complained - that the pupils were not really able to solve the task. However, this is not astonishing at all, since "counter-factual" suggestions and anachronistic errors are rarely, if at all, mentioned or analyzed in history lessons (to say nothing about pith-helmets and short pants). At best, our instruction is only oriented towards re-construction from - reliably true and pre-selected - primary sources; at worst, it does not go beyond the drawing of information from - unquestioned - primary sources. It is unfair to test second order skills or concepts which definitely have not been taught before.

This Pandel-assignment can be done with paper and pencil, as a short essay. Maybe it could even be transformed into a "multiple choice" form:

"Which sentence explains the picture and its information best:

For tourists in Egypt the use of computers is forbidden.

The picture has the character of a caricature and is a joke.

An ancient Egyptian king ordered the destruction of all computers.

Archaeologists found out that already the ancient Egyptians used computers." 
But what is measured by the marking with a correct cross or - more complicated for students and researchers - by a good short essay? There is a certain hint of a conventional methodical competence. ${ }^{8}$ Detecting a major anachronistic mistake - even in the form of a dumb joke - is an achievement. The insight that it is possible for a stupid error to appear in print - even in a serious book - may be even more important. This is a characteristic of critical thinking, though not really specific for the cognitive domain of history. But the capacity of narrating and understanding history is not directly examined by the Pandel-assignment. The impact on the self and its historical definition ("self-reflection") is completely lost.

Another example of the attempt to evaluate historical thinking stems from the group "Chata" around Peter Lee, which attempts to test students' competences in middle range concepts (second order concepts) in the course of a method-orientated curriculum (comp. History in the National Curriculum 1995) (Lee/Ashby 2000). In different grades, Lee presents two short versions of the "End of the Roman Empire". He restricts himself to very short versions (30 lines) with comic-style drawings (not with two long chapters and complicated primary sources!). The meaning is rather simple: The first version dates the "fall" in 476 , but mentions the existence of Byzantium, the other describes the "fall" in 1453, having spoken of the end in the West before and giving a map of the split Empire. Afterwards the students have to produce short texts or oral presentations about the relation between both narrations.

The test can be done by paper and pencil (Lee's group used short essays), by an interview or - again - by the transformation into a multiple choice format. ${ }^{9}$ But then, more than one sentence can be correct and less than three incorrect.

In the two texts, the meaning of the term "The Fall of the Roman Empire" is a different one.

Both texts contradict each other: The Roman Empire can only have fallen in 476 or in 1453.

Different historians use different pieces of information and therefore draw different conclusions.

8 Demanding a "short essay" would cost students more time for writing and teachers more time for evaluation. But it would be analytically far superior, because it would show the structure and reasons of students' insights and errors in detail.

9 In this format, the students do not write themselves, but think about solutions. Therefore the risk of omitting the questions - and missing data - is smaller. Nevertheless, the logic of false answers can be analyzed. 
Decisions of controversies in history are not so easy; there are no sufficient arguments for 476 or 1453.

Since we weren't there and nobody is an eye-witness of 476 or 1453, we cannot know when the Roman Empire fell.

A "Roman Empire" has to control Rome; therefore "The Fall of the Roman Empire" was in 476.

The Byzantine State is a continuation of the Roman one; therefore "The Fall of the Roman Empire" was in 1453.

The situation is doubtful; we have to look for what the best and most famous historians (and the handbooks) say.

History is written from "primary sources" of contemporaries: We must examine what they say about 476 and what about 1453.

Some of these versions may be doubtful and some may be suggestive (additionally, the correct ones may promote the learning process, which had failed before, in the situation of the test itself). In our context, the other problem is much more important: What does this assignment test? It is focusing on the relation between the past and the historical interpretation/narration. The past was full of innumerable (billions of billions of) particles of reality, most of them unknown today, never having been written down, painted or sculptured - or having since been lost completely.

History is a hypothetical construction and narration about relevant parts of processes in the past with consequences for today. It requires words, notions, terms and concepts which are adequate to the past itself, to us and to our relation with the past. Those concepts have a huge impact on the histories told. To realize this and to apply this thinking to a case of historical interpretation is an important part of methodical competence and concept competence (See also the contribution by Andreas Körber in this volume). It may even have an influence on self-reflection.

Peter Lee's group used the assignment in a short essay version. We should have a brief look at their qualitative and quantitative results, which show the assignment to be a very powerful instrument for diagnosis. Three basic concepts in the answers are distinguished: "factual", "multiple past" and "criterial" (Lee/Ashby 2000: 208).

- In the first concept, the problem is facts and errors; the two reports about "the end of the Roman Empire" are contradictory. The vast majority of the students (more than three quarters) in second and fifth grade hold this conviction, but one third even in eighth grade.

- The second concept is a medium or transition solution (an example of "seeking" instead of clear "explanation"): History is more complicated and multiple than you think. Perhaps there is a chance to 
combine both reports. This is written by tiny minorities in the second and fifth grade, but by larger numbers in sixth and eighth grade.

- The third concept includes a differentiation of the notion "end of the Roman empire" itself: Does it mean "Western Rome" only or "Eastern Rome" ("Byzantium") as well? Both texts - with different though homonymous/homophone terms - are not at all contradictory. The insight that it is a question of the criteria used is inaccessible to pupils in second and fifth grade, but attainable for $25 \%$ in sixth and $40 \%$ in eighth grade.

Of course, this is a rather disappointing or discouraging result. What might seem a very simple and logic conclusion to experts suggestively offered by the short texts themselves, is not so obvious in the way lay people relate to history. The theoretical - but empirically substantiated five levels of "progression in students' ideas about accounts and their relation to the past" (Lee/Ashby 2000: 212) should be added. This is really a developmental model (among others of "Chata") which can be applied (perhaps in a revised form) to other concepts of particular historical competencies of the middle range (second order concepts). The progression in students' ideas about accounts (i.e. historical narrations, B.v.B.) and their relation to the past are listed as follows:

- The past as given. Stories are about the same thing: The story is equivalent to something "out there".

- The past as inaccessible. We can't know - we weren't there. Nothing can be known. Differences in accounts are a result of lack of direct access to the past.

- The past as determining stories. Stories are fixed by the information available; there is a one-to-one correspondence. Differences in accounts are results of gaps in information and mistakes.

- The past as reported in a more or less biased way. Shift of focus from the story and reports to the author as active contributor. Differences in accounts are a result of distortion (in the form of lies, bias exaggeration, dogmatism); the problem is not just a lack of information.

- The past as selected and organized from a viewpoint. Stories are written (perhaps necessarily) from a legitimate position held by the author. Differences in accounts are a result of selection. Stories are not copies of the past.

- The past as (re-)constructed in answer to questions in accordance with criteria. Shift of focus from the author's position and choice, to the nature of accounts as such. It is the nature of accounts to differ. (Lee/Ashby 2000: 212) 
In fact, we do not really know the reasons for the poor outcome mentioned above: Lee/Ashby (2000) suppose that even in the English case of a method-oriented curriculum, the teachers fail to provide sufficient promotion, stimulation and exercise of historical thinking during the lessons. One could add: It seems that many teachers are fixed on contents and are sometimes confounding past, facts, interpretation, narrative and history themselves. But that's a supposition only; What to do if teachers have intensively tried to teach historical thinking and reflection, but pupils prefer simplicity, security and un-ambiguity?

This is only one example of the project "Chata", but it perfectly shows the type of diagnosis conducted by the British researchers and history didacticians. Though a paper-pencil method and partly designed for placing a tick only (see Lee et al. 1998: 237), the approach is vastly superior to the typical German testing, but of course it in no way covers the two main domains of personal identity and long-term biography. Tests cannot validly diagnose the anticipation of future positions and decisions. And they must not grade the normative convictions and existential conclusions of the pupils (as long as the democratic constitution and human and civil rights are loyally observed).

\section{Testing "dealing with history"10}

For the reflecting and (self-)reflective dealing with history some qualifications are turning points, i.e. elaborated use of primary sources (mostly texts), but also the critical use of historiography or narrations (mostly texts as well), and finally the application to new cases and situations (transfer of insights). At the same time, historical argumentation should be examined, e.g. the distinguishing of occasion - or pretext - (causality of surface) and reason - or cause - (causality of deep structure) and additionally the weighting of controversies (especially concerning the structural causes).

The topic "Great Witch Persecution" $" 11$ has a high status of relevance in Germany, much higher than in other countries. ${ }^{12}$ It is quite clear that

10 For the following propositions, I feel inspired and encouraged by two lectures in Goettingen (31.3.-2.4.2008) of the circle of Robert Selman on the one hand and Sam Wineburg on the other hand. Interestingly, the approaches included one project with closed items (Alan Stoskopf and Ulrike Hartmann) and another with open items (Avishag Reisman). The second one will be published soon in Martens e.a. 2010, the first one seems to remain unpublished. None of my proposals is a direct application or translation. 
"Witch Hunt" is an excellent parallel or similar phenomenon to Nazicrimes - and therefore adequate for an experimental test of transfer abilities. $^{13}$

\subsection{Analysis of primary sources}

The knowledge and analysis of the perspective character and interest orientation of all primary source texts is a very basic point. Therefore, it is fruitful to present a short text of that type (or a picture as well) for evaluative analysis. Short essays are common, but "multiple choice" can be tried as well:

\section{"A Document about the 'Great Witch Hunt'}

Petition of the municipality Elz near Limburg/Lahn in 1589 to the Archbishop and Elector of Trier: ' [...] we poor supplicants beseech Your Electoral Grace in the matter of the suspicious and disreputable sorceresses, as we have already at various times most humbly besought Your Electorial Grace for the sake of God, to order Lord Keller to question them [the witches] and execute, what will reveal itself as truth and be declared as justice. Because, most graceful Prince and Lord, should such great and pernicious harm as hath befallen us not be punished, they [the witches] would be strengthened in their designs, and we would be forced to take flight with our wives and children and to leave everything behind."' (Schormann 1981: 56)

Of course, it is easy to make students evaluate this text with an open formulation, i.e. in a short essay. "Please analyze the position, the interests and the intentions of the authors and reflect which relevance the

11 Compare a teaching model 'The 'Great Witch Persecution' (1555-1665) Death Throes of Middle Ages or Birth Pangs of Modern Times?" in Borries 2003: 177-206.

12 To give British North-America as an example: The Witch Hunt in Salem 1692 , where the judge officially asked for forgiveness from the victims and the survivors some years later, has been a single case; in Germany, there have been at least fifteen thousand casualties during four centuries (although the three hundred thousand or nine million sometimes mentioned are apparently overestimated by far).

13 Some years ago, large groups of students (6th, 9th and 12th grades) were questioned about the "Great Witch Hunt", especially about their emotions, partisanships, abilities of empathy, moral judgements, and conclusions for today (see Borries et al. 1992: 58-63, 200f.). Some of the strategies of this study can be transformed into a testing of historical reflections as well. 
quoted contemporary evidence can have in respect to the explanation and judgement of witch trials." 14 The short interpretations could read:

- "The Elector of Trier puts the responsibility for his cruel acts against the supposed 'witches' at other people's door, like his council and his subjects."

- 'The applicants are very sure on the subject of 'witches' and act rather decidedly and cunningly: By threatening to run away (emigrate) if the prince doesn't punish the witches they are in effect blackmailing him."

- "Hatred between Catholics and Protestants was one of the main reasons of the Great Witch Hunt in the $16^{\text {th }}$ and $17^{\text {th }}$ century."

- "Influential subjects themselves repeatedly demanded the persecution of 'witches' from their authorities. According to their conviction, these 'witches' caused them much harm through sorcery."

- "If such letters are frequent, one could conclude that there was a deep-rooted fear and bitter hatred among the normal people in the villages."

- "The rulers are by no means the only ones responsible for or guilty of the witch hunt. They have to take the convictions, wishes and feelings of their subjects into account."

- "The practice of accusing individuals of sorcery seems to have been something so frequent and normal that one can conclude: Attempts to perform witchcraft - at least making evil wishes or casting the evil eye - must have been common then."

- "Even in the dark, superstitious times of the $16^{\text {th }}$ century, enlightened people often warned against witch hunts and the torture and cruel burning of innocent women."

Apparently, here we have the interesting case of complexity and controversy: Not one version is completely and definitely correct. And most of the others cannot be taken as undoubtedly erroneous or absurdly remote. Instead, different levels of understanding are possible, which may be linked to competences. But such items demand remarkable methodical

14 But it is also possible, to write a set of interpretations or commentaries about the text (more or less correct and complex) and to make the students rate these texts with a five step Likert scale:

Completely unplausible; Mainly unplausible; So-so; Mainly convincing; Completely convincing

Obviously, some critics will argue that it would be fair to add an additional answer "don't know"; but the interpretation of a primary source text is not a task to refuse legitimately. For the ignorant and anxious ones, the existence of a version "so-so" is already an offer (without loss of data for further calculations). 
standards, first in the process of construction of the items by the researchers. It would be necessary to make small experimental groups write short essays, to analyze and classify those texts and to transform some typical remarks into test items. Without a qualitative pilot study such quantitative research is methodically (and normatively) impossible or at least unwelcome.

These experimental versions should be tested (tried) with larger samples. In this way, the earlier mentioned suggestions about levels of difficulties and levels of competences in the different versions can be verified: Have the students' articulations been predicted correctly? Thus, in the next phase, the evaluation of the students is less important than the verification or falsification - and revision - of precedent theories about levels of difficulties, learning processes and the logic of development of competencies.

\subsection{Production of historiography}

On the other hand, such items, even if answered correctly, do not guarantee historical understanding in a comprehensive sense, but only the correct understanding of particular historical texts. This is a very important difference. The mentioned achievements, which have the character of criticism of primary sources, could be introduced and exercised in a conventional source-oriented teaching. Of course, this is not meant negatively. But more is needed for historical understanding, i.e. the production of one's own historical description/narration and the analysis of divergent historical descriptions/narrations (this is called competence of de-construction).

What does that mean for our example? Undoubtedly, a small set of primary sources (two texts, two quotations from the Bible, two woodcuts) had to be combined. To remain realistic, the whole collection could not exceed two or three printed pages in a testing situation. Additionally, the learners should first formulate questions on the material and then try to give a written presentation. It is nearly impossible to imagine this in a format of closed questioning (e.g. multiple choice); but in view of the limited time available, requiring the learner to create a mind map could be a better solution than demanding a fully elaborated short essay.

It would be preferable to present a larger collection of diverse primary sources (pictures and texts), some theories, some transfers to the present (propositions of historical orientation), different forms of fiction (pictures and texts), different narrations (pictures and texts), and to give the students the task to produce their own sense-making narration (with legitimation and argumentation) on the basis of this collection. This 
would of course take at least three hours. We have occasionally carried this out at university level (see Borries 2006, 2007). The results have been rather problematic, even discouraging. Apparently, university students interpret these demands as highly overburdening, but also as provocative.

Apparently, written history class tests and even essays under exam conditions at university usually follow the model of a simplifying analysis of primary sources and content problems. In fact, it seems altogether uncommon to ask for the production of a synthetic sense-making narration or a critically qualified judgement about other pre-fabricated narratives. Thus, the usual exam question seems just an unfortunate mixture of arbitrary - and relatively simple - parts falling between what have been termed competence of "re-construction" and the competence of “de-construction” (Körber et al. 2007; Schreiber/Körber et al. 2006; See also the contribution by Lenz in this volume).

\subsection{Analysis of historiography}

The next task is of course just the opposite one: short narrations of the "Witch Hunt" have to be compared and evaluated. ${ }^{15}$ Again, a series of pictures from the $19^{\text {th }}$ century - or a memorial of the $20^{\text {th }}$ - could be integrated and added to two popular texts. Surely, such a request for deconstruction will first be arranged with open answers (short essays). But why not try to construct a set of prototypical stages from typical - more or less elaborated - articulations among experimental groups? These could be presented to learners for a rating via ticking boxes. One could also attempt to correlate particular positions to different political sympathies. As already said, it is especially important to distinguish "causes" and "occasions" and to combine and discuss several incidental and also structural interpretations.

As a substitute, I have listed six - basically contradicting - models of explanation of the "Great Witch Persecution" (see Borries 2003: 196199). Since the list is shortened to half its length, they are probably inadequate in respect to their amount, but perhaps overburdening in respect to their degree of difficulty. The focus is not on the narration itself (it easily becomes too long), but on the theoretical ascription of causalities (background and deep-structure reasons). Here I quote only two especially contradicting - examples:

15 In fact, because of the limitations on time in a testing situation, only contradicting short judgements can be presented. 


\section{Six Explanations of the "Great Witch Persecution"}

Thesis 1: The obsessive belief in witches is a typical spawn of medieval superstition and dark sadism. It is based on pathological notions in the heads of fanatic theologians, who were enemies of science, and men of law, who were blind to reality. Thus, deviant minorities and autonomously thinking people could be intimidated and eliminated. It took a very long time until modern Enlightenment drove away these haunting ghosts and replaced fear of the supernatural by rational scientific explanations: "Since I assume the vice of witchcraft to be a myth, I advise this one precaution only: A prince should never allow an investigation to be conducted [...] on the grounds of the vice of witchcraft, i.e. the alliance of human beings with the devil" (a philosopher of the Enlightenment, 1701).

Thesis 6: The witch trials primarily served religious and secular authorities to discipline and intimidate the rural subjects. Previously, priests and noblemen had tolerated all kinds of superstition and magic in the almost independent villages: "Often men and women came to see her (an old woman) in her house, begging her to release their friends, who had been bewitched, from the curse [...]. She can bring a husband back to a woman" (a witness from 1446). Henceforth, the soul was to belong exclusively to the church, the body unconditionally to the king. The persecution of witches was the most brutal phase of a long struggle, at the end of which man came to be shaped and moulded to the requirements of the modern state, conformist, manipulated and controlled. It is precisely this that constitutes the mental aspect of the long transition from medieval feudalism to modern capitalism. In that sense, the witch hunts are a spawn and a manifestation of modern rationality and of a strategy of modernization.

Again, one could choose an open-question format, i.e. a list of questions like the instructions for working with textbooks. In this way, an evaluation of the theses can be promoted and demanded. Afterwards the outcomes can be rated/coded according to strict criteria, so that even quantitative studies are possible.

"Which questions do you formulate after reading the six theses? By which procedures do you try to answer them? Which additional information would you like to have and use? Where would you have a chance of accessing it? How do you provisionally assess the mutual connection of the six theses and their peculiar persuasiveness?"16

16 An alternative, more detailed order - with other focuses and more help could read: 
Such a qualitative preliminary stage with an experimental group is unavoidable in the case of larger investigations. Afterwards, an attempt with closed items - and therefore quantitative methods - can be undertaken. ${ }^{17}$ But for the moment it is not really clear how far it will be successful in testing the ability for historical reflection.

At the end, a request to rank the statements in an explicit order could be added:

"Please rank the six theses suggesting an explanation of the 'Great Witch Hunt' according to: which one you consider the most convincing(1), which one the second most (2), which one the least (6), which

"Please, discuss the six theses and decide - as far as possible - to which extent they are valid for you. The following questions may be helpful:

- Where is the persecution of witches said to be typically 'medieval', where specifically 'modern'? On which side is 'rationality', on which 'superstition', found in the respective explanations?

- To which degree are general social and mental mechanisms described, which can produce similar phenomena in all situations and epochs? To which degree are very specific circumstances of the late 16th and early 17 th century mentioned and made responsible?

- Which theories assume 'witchcraft' to be a real phenomenon (though not a crime worthy of death sentences)? Which ones declare it to be an invention, a myth or a figment of the imagination of the persecutors or the persecuted?

- Which explanations remain general and neutral towards gender? Which give reasons for the fact that mainly women were accused and executed?

- Who is the main blame for the large-scale judicial murder attributed to? Please analyze in particular whether the activities are assigned to the 'authorities' or to the 'subjects' themselves!

- Which explanations can be combined with each other, which ones contradict others directly and unequivocally? Discuss the scope and the persuasiveness of each theory!"

17 Every statement could be rated by the students according to several categories. Here is a sketchy draft (valid for all six theses):

"As an explanation of the 'Great Witch Persecution' thesis 1 [2, 3 etc.] is (answer only 'Yes', 'Un-decided' and 'No') [...]

a) [...] convincingly argued and consistent in itself

b) $[\ldots]$ well compatible with the other statements

c) [...] completely arbitrary and rather far-fetched

d) [...] intelligently concluded from the known facts

e) [...] strongly biased in the interest of certain involved groups

f) [...] irrelevant for us today - with our different rules and habits

$g)[\ldots]$ worked out perfectly from the contemporary conditions of those times

h)[...] much too lenient towards the crimes of those who committed them at the time

i) [...] perfectly uncommon and unexpected, but productive and enlightening" 
one the second least (5) and which one you would put in the middle (3, 4).

\section{Thesis 1 Thesis 2 Thesis 3 Thesis 4 Thesis 5 Thesis 6"}

\subsection{Transfer achievement}

Obviously, the fourth step has to be the application (transfer). In order to show (and measure) the qualifications described above, it will however be necessary to use new topics instead of recurring to already familiar ones. Therefore it is important to rely on similar or equal categories (e.g. "cause" and "occasion", "perspectivity", "controversy"). If, for instance, the subject matter "witches" has already been discussed in the classroom, it would not be appropriate to use it for the following exam or test. Instead, the topic could perhaps be a xenophobic riot or an antiSemitic pogrom, violent protests against the Huguenot immigrants in Germany around 1720 or the shooting of Belgian hostages by the Germans at the beginning of World War I in 1914. Nevertheless, in its structure, the questionnaire could, even should look like the one about the "witches" described above.

When measuring the transfer, new problems arise. What do researchers really measure when they expect insights into deep structure causes may be gained from the "Witch Hunt", but are used for "Persecution of Jews 1933/45" or "Xenophobic Riots 1993"? Is this really historical thinking? By generalizing a certain figure or mechanism and making it obligatory or transferable to other cases, we have to exclude changes and fix or prolong ongoing rules automatically (standstill). This suggests purely exemplary sense-making as Rüsen understands it (1994b: 37-41, 85-90, 150-155, 231-234) one might call it social-psychological insight as well, which implicitly assumes that the logic of social behavior has not changed in the course of long historical processes, not even during the process of modernization and in times of pressure and crisis.

As historians, we will find this restriction problematic (but that is a general dilemma of presence-related historical learning). Without a genetic sense-making - as well as a critical one, which means distancing oneself from an accepted interpretation - there is no chance at all (Rüsen 1994b). But how can these figures be tested and how can sentences of genetic character (e.g. "in fact at that time [...], but today [...]" or "already then [...], and even more today [...]") be classified as "correct", "so-so" or "false"? Admittedly, with this point, we are not only in the center of a sensitive question of diagnosis, but in a mine-field of theory itself: Which status can exemplary - and traditional - sense-making preserve in a world with unavoidably dominant genetic interpretations? 


\section{Final remarks}

As already mentioned, the possibilities of testing by paper-pencil formats are much greater than the current practice in most countries. This paper was mainly about experiments which should be performed by supporters of reflecting and (self-)reflective history learning, before more and more boring, anti-reflective knowledge-tests (see above) flood the market. According to my experience, most teachers are critical towards tests (e.g. multiple choice formats), but not towards their mere content-based - and sometimes dogmatic unambivalent - logic itself. It is very important to know and to practice more intelligent and more elaborated paper-pencil-questions even of closed types (crossing and ranking), but of open types (mental maps, short essays) as well.

Apart from paper and pencil, we have other opportunities for diagnosis during the teaching itself, which are more suitable for goals that are not operationalized or cannot be operationalized. In projects, pupils can be observed while they are investigating, discussing, reflecting, presenting, evaluating, comparing, judging, transferring to other cases and personal life etc. Even (very cautious) assumptions can be made about their future behavior in a long-term perspective (life and biography), and their sense-making in private, communicative and public situations may be improved to some extent by these merely qualitative methods (which are often not compatible with exam grades). The simple reason is that the young people have already tried and executed such processes themselves and can transfer the competences to other situations and use them successfully. To describe these observations which cannot be quantified or objectified mechanically, in detail, would be the subject of another article.

\section{References}

Borries, Bodo von (1992) (in cooperation with Dähn, Susanne, Körber, Andreas and Lehmann, Rainer H.): Kindlich-jugendliche Geschichtsverarbeitung in West- und Ostdeutschland 1990. Ein empirischer Vergleich (= Geschichtsdidaktik. Studien, Materialien. Neue Folge 8), Pfaffenweiler.

Borries, Bodo von (1997): Wendepunkte der Frauengeschichte II. Über Muttergöttinnen, Männeransprüche und Mädchenkindheiten. Modelle und Materialien zum Ausprobieren und Bessermachen, Centaurus, Herbolzheim. 
Borries, Bodo von (2004): Lebendiges Geschichtslernen. Bausteine zu Theorie und Pragmatik, Empirie und Normfrage (= Forum Historisches Lernen), Wochenschau Verlag, Schwalbach/Ts.

Borries, Bodo von (2006): “'Fremdverstehen' - 'Empathieleistung' 'Abenteuerfaszination'? Zu Chancen und Grenzen interkulturellen Geschichtslernens”. In: Manuela Boatcă et al. (eds.), Des Fremden Freund, des Fremden Feind. Fremdverstehen in interdisziplinärer Perspektive, Waxmann, Münster, pp. 65-84.

Borries, Bodo von (2007): “'Geschichtsbewusstsein' und 'Historische Kompetenz' von Studierenden der Lehrämter Geschichte”. In: Gerhard Henke-Bockschatz (Mod.), Geschichtsdidaktische empirische Forschung (= Zeitschrift für Geschichtsdidaktik 6. Jg. Jahresband 2007), Wochenschau, Schwalbach/Ts., pp. 60-83.

Borries, Bodo von (2008a): Historisch Denken Lernen Welterschließung statt Epochenüberblick. Geschichte als Unterrichtsfach und Bildungsaufgabe, Budrich, Opladen und Farmington Hills.

Borries, Bodo von (2008b): “'Orte’ des Geschichtslernens - Trivialität oder Schlüsselproblem?”. In: Saskia Handro/Bernd Schönemann (eds.), Orte historischen Lernens, LIT, Berlin, pp. 11-35.

Die Welt: "Was die Deutschen über ihre Geschichte wissen", 25.5.2005, pp. 10-15.

Frankfurter Rundschau: "Wie deutsch sind Sie", 3.9.2008, pp. 25-32.

Füßmann, Klaus/Grütter, Heinrich Theodor/Rüsen, Jörn (eds.) (1994): Historische Faszination. Geschichtskultur heute, Böhlau, Köln.

History in the National Curriculum. England; London (HMSO) (1995).

Jeismann, Karl-Ernst (1985): Geschichte als Horizont der Gegenwart, Schöningh, Paderborn.

Jeismann, Karl-Ernst et al. (1987): Die Teilung Deutschlands als Problem des Geschichtsbewußtseins. Eine empirische Untersuchung über Wirkungen von Geschichtsunterricht auf historische Vorstellungen und politische Urteile, Schöningh, Paderborn.

Körber, Andreas/Schreiber, Waltraud/Schöner, Alexander (eds.) (2007): Kompetenzen historischen Denkens. Ein Strukturmodell als Beitrag zur Kompetenzorientierung in der Geschichtsdidaktik (= Kompetenzen: Grundlagen - Entwicklung - Förderung, vol. 2), ars una, Neuried.

Lee, Peter/Ashby, Rosalyn (2000): "Progression in Historical Understanding among Students Ages 7-14”. In: Peter N. Stearns/ Peter Seixas/Sam Wineburg (eds.), Knowing, Teaching, and Learning History, New York University Press, New York, pp. 199-222. 
Lee, Peter/Dickinson, Alaric/Ashby, Rosalyn (1998): "Researching Children's Ideas about History”. In: James F. Voss/Mario Carretero (eds.), Learning and Reasoning in History (= International Review of History Education 2), RouteledgeFalmer, London, pp. 227-251.

Martens, Matthias et al. (eds.) (2010): Interpersonal Understanding in Historical Context, Sense Publishers, Rotterdam, Boston, Taipei.

Pandel, Hans-Jürgen (2005): Geschichtsunterricht nach PISA. Kompetenzen, Bildungsstandards und Kerncurricula (= Forum Historisches Lernen), Wochenschau, Schwalbach/Ts.

Ricoeur, Paul (1988/1989/1991): Zeit und Erzählung, 3 vol., Wilhelm Fink, München.

Rüsen, Jörn (1983): Historische Vernunft. Grundzüge einer Historik I: Die Grundlagen der Geschichtswissenschaft, Vandenhoeck \& Ruprecht (Kleine Vandenhoeck-Reihe; 1489), Göttingen.

Rüsen, Jörn (1994a): Historische Orientierung. Über die Arbeit des Geschichtsbewußtseins, sich in der Zeit zurechtzufinden, Böhlau, Köln.

Rüsen, Jörn (1994b): Historisches Lernen. Grundlagen und Paradigmen, Böhlau, Köln.

Schormann, Gerhard (1981): Hexenprozesse in Deutschland, Vandenhoeck \& Ruprecht (Kleine Vandenhoeck-Reihe; 1470), Göttingen.

Schreiber, Waltraud (mod.) (2003): FUER Geschichtsbewusstsein. Ein internationales geschichtsdidaktisches Forschungsprojekt zum Geschichtsunterricht (= Zeitschrift für Geschichtsdidaktik, 2. Jg. 2003, Jahresband).

Schreiber, Waltraud/Körber, Andreas/Borries, Bodo von/Krammer, Reinhard/Leutner-Ramme, Sibylla/Mebus, Sylvia/Schöner, Alexander/Ziegler, Béatrice (2006): Historisches Denken. Ein KompetenzStrukturmodell (= Kompetenzen: Grundlagen - Entwicklung - Förderung, vol. 1), ars una, Neuried. 



\section{Contributors}

Sirkka Ahonen is professor emerita of history and social science education in the University of Helsinki, Finland. Her research interests and publications reach from the nature of historical learning to the use of history education in post-communist and post-conflict countries and, moreover, to the history of school politics in regard to equity in education.

Cecilie Felicia Stokholm Banke is senior researcher and Head of Research Unit in Holocaust and genocide studies at the Danish Institute for International Studies in Copenhagen. She holds a Ph.D. in history from Roskilde University, a MA in history and sociology from Roskilde and Lund Universities, and is specialized in 19th and 20th century European history with a special focus on European nation states and nationalisms and the Interwar years. Her current research focuses on politics of memory and memory culture.

Helle Bjerg works as a associate professor in history didactics and researcher in the pedagogical field at University College Copenhagen. She holds a MA in history and communication and is currently finishing a Ph.D.-thesis in social psychology and educational history. She has published within the field of historical consciousness and memory cultures related to World War II and the Holocaust.

Bodo von Borries has obtained his doctorate in economic and social history and has taught history and German language/literature at high school. From 1976 to 2008 he was professor of education (with special consideration to history didactics) at Hamburg University. He has pub- 
lished many books and articles on learning history (empirical, theoretical, normative and pragmatic approaches and studies).

Tor Einar Fagerland is associate professor at the Program for Cultural Heritage Management, Department of History and Classical Studies, at the Norwegian University of Science and Technology. He holds his Ph.D. in medieval history. His current research focuses on uses of the past in the present and on how to deal with painful and ambiguous heritage.

Kristian Gerner is professor emeritus in history at Lund University. In 1994-2002 he was professor of Central and East European cultural history at Uppsala University. In 1982 and 1985 he was a guest researcher at the Swedish Institute of International Relations and in 1988-89 a fellow at Netherlands Institute for Advanced Studies. He has published widely within 20th century cultural and environmental history, Holocaust and Communist studies, and conflict research.

Tom Gullberg is senior lecturer in history didactics and civics education at Åbo Akademi University in Vaasa, the Swedish university of Finland. He holds his $\mathrm{Ph} . \mathrm{D}$. in general history and his fields of research are European modern history, history of identities, and history didactics.

Klas-Göran Karlsson is professor of history and the leader of the Graduate school of history didactics at Lund University, Sweden. He has published extensively in Russian and Soviet studies and in genocide studies. For a long time, he has also taken an interest in problems related to European historical cultures and uses of history.

Andreas Körber is professor in education with a special regard to didactics of history and political education at Hamburg University. He has done research and published on theory of history and historical thinking, intercultural education in history, historical consciousness and history teaching in the information age, and is co-author of a model of competencies for the domain of historical thinking.

Claudia Lenz works as R\&D coordinator at the European Wergeland Centre for Education on Intercultural Understanding, Human Rights and Democratic Citizenship. She holds her Ph.D. in political science and her fields of research and publication are historical consciousness, memory cultures, and memory politics with regard to World War II and the Holocaust. 
Trond Risto Nilssen is historian and senior curator at the Falstad Human Rights Centre and associate professor at the North Trondelag University College in Norway. He has published within the fields of memory culture/uses of history after 1945, WWII history (prisoners of war in Norway), and the transitional period of May 1945 and onwards in Norway.

Jon Reitan works as Senior Curator at the Falstad Centre and Ph.D. Candidate in history at the Norwegian University of Science and Technology. He has published within the fields of memory studies, historical cultures, and the Holocaust.

Ola Svein Stugu is professor at the Department of History and Classical Studies at the Norwegian University of Science and Technology, Trondheim, and heads the institution's study program in cultural heritage management. He has published within the fields of public history, history didactics, and cultural history, as well as in modern urban and regional history.

Erik Thorstensen is educator at the Center for Studies of Holocaust and Religious Minorities in Norway. He is an MA in history of religions and has published in comparative literature, religious sciences, and ethics.

Ulf Zander is associate professor in history at Lund University and senior lecturer at Malmö University. His doctoral thesis from 2001 was on debates on and uses of Swedish history from late 19th century to early 21 st century. He has also written a book about American film, history and identity (2006). His latest book deals with the politics and representations of Raoul Wallenberg after 1945 (2010). Zander has co-edited a number of anthologies and was the editor of Scandia, one of the leading Swedish Academic journals in history, 2003-05. 
